\title{
(De)monstration: Interpreting the monsters of English children's
} literature.

\section{Padley, Jonathan}

How to cite:

Padley, Jonathan (2006) (De)monstration: Interpreting the monsters of English children's literature.. thesis, Swansea University.

http://cronfa.swan.ac.uk/Record/cronfa42979

Use policy:

This item is brought to you by Swansea University. Any person downloading material is agreeing to abide by the terms of the repository licence: copies of full text items may be used or reproduced in any format or medium, without prior permission for personal research or study, educational or non-commercial purposes only. The copyright for any work remains with the original author unless otherwise specified. The full-text must not be sold in any format or medium without the formal permission of the copyright holder. Permission for multiple reproductions should be obtained from the original author.

Authors are personally responsible for adhering to copyright and publisher restrictions when uploading content to the repository.

Please link to the metadata record in the Swansea University repository, Cronfa (link given in the citation reference above.)

http://www.swansea.ac.uk/library/researchsupport/ris-support/ 


\title{
(DE)MONSTRATION:
}

\section{INTERPRETING THE MONSTERS OF ENGLISH CHILDREN'S LITERATURE}

\author{
Jonathan Padley
}

Submitted to the University of Wales in fulfilment of the requirements for the Degree of Doctor of Philosophy

$$
\text { University of Wales Swansea }
$$

January 2006 
ProQuest Number: 10821369

All rights reserved

INFORMATION TO ALL USERS

The quality of this reproduction is dependent upon the quality of the copy submitted.

In the unlikely event that the author did not send a complete manuscript and there are missing pages, these will be noted. Also, if material had to be removed, a note will indicate the deletion.

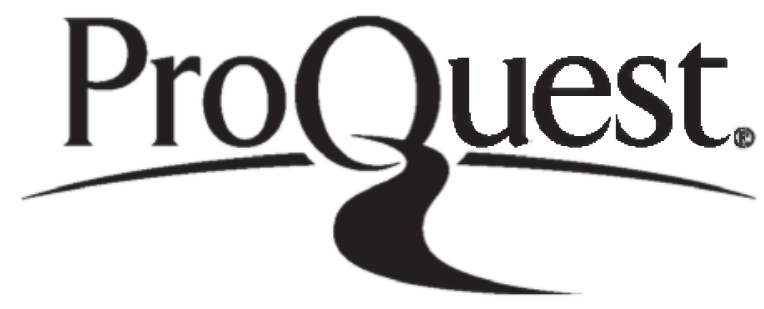

ProQuest 10821369

Published by ProQuest LLC (2018). Copyright of the Dissertation is held by the Author.

All rights reserved.

This work is protected against unauthorized copying under Title 17, United States Code Microform Edition (C) ProQuest LLC.

ProQuest LLC.

789 East Eisenhower Parkway

P.O. Box 1346

Ann Arbor, Ml $48106-1346$ 
s 


\section{$\underline{\text { SUMMARY }}$}

This thesis is intended to document and explain the peculiarly high incidence of monsters in English children's literature, where monsters are understood in the term's full etymological sense as things which demonstrate through disturbance. In this context, monsters are frequently young people themselves; the youthful protagonists of children's literature. Their demonstrative operation typically functions not only as an overt or covert tool by which to educate children's literature's implied child audience, but also as a wider indicator demonstrator - of adult appreciations of and arguments over children and how children should be permitted to grow. In this latter role especially, children are rendered truly monstrous as alienated and problematic tokens in adult cultural arguments. They can fast become such efficient demonstrators of adult crises that their very presence engenders all the notions of unacceptability with which monsters are characteristically associated.

The chronological range of this thesis' study is the eighteenth-century to the present. From this period, the following children's authors, children's books, and series of children's books have been examined in detail:

- Thomas Day: Sandford and Merton

- Anna Laetitia Barbauld: Lessons for Children and Hymns in Prose for Children

- Sarah Trimmer: Fabulous Histories

- Mary Martha Sherwood: The Fairchild Family

- Charles Kingsley: The Water-Babies

- Lewis Carroll: Alice's Adventures in Wonderland and Through the Looking-Glass

- George MacDonald: At the Back of the North Wind

- J.M. Barrie: Peter Pan in Kensington Gardens, Peter Pan, and Peter and Wendy

- C.S. Lewis: The Chronicles of Narnia (The Lion, the Witch \& the Wardrobe, Prince Caspian, The Voyage of the Dawn Treader, and The Last Battle)

- J.K. Rowling: Harry Potter (The Philosopher's Stone, The Chamber of Secrets, The Prisoner of Azkaban, The Goblet of Fire, The Order of the Phoenix, and The HalfBlood Prince).

The theoretical notions of monsters and monstrosity that are used to discuss these texts draw principally on the writings on the sublime by Edmund Burke and Immanuel Kant, the uncanny by Sigmund Freud, and the fantastic by Tzvetan Todorov. 


\section{DECLARATION}

This work has not previously been accepted in substance for any degree and is not being concurrently submitted ph candidature for any degree.

Signed

Date $01 / 08 / 06$

\section{STATEMENT 1}

This thesis is the result of my own investigations, except where otherwise stated. All sources are acknox ledgdd bv footnotas giving explicit references. A bibliography is appended.

Signed

Date $01 / 08 / 06$

\section{STATEMENT 2}

I hereby give consent for this thesis, if accepted, to be made available for photocopying and for inter-library loan, and for its title and summary to be made available to outside organizations.

Signed.

Date $01 / 08 / 06$ 


\section{CONTENTS}

Acknowledgements $\quad$ v

Dedication $\quad$ vi

Abbreviations vii

$\begin{array}{ll}\text { Introduction } & 1\end{array}$

1. Monstrous Children: The Discourse of the Different 7

2. The Genesis of English Children's Literature 24

3. Thomas Day: Sense Versus Sensibility 33

4. Anna Laetitia Barbauld: Double Dissension 57

5. Sarah Trimmer: The Guardian of Education 79

6. Mary Martha Sherwood: Killjoy or Joyful Killer? 102

7. Charles Kingsley: Expanding Margins and (Mis)Reading The Water-Babies 123

8. Lewis Carroll: Who the $\mathrm{F}^{* *} \mathrm{k}$ is Alice? 146

9. George MacDonald: God's Solitary Baby 175

10. J.M. Barrie: 'I Can’t Get My Shadow to Stick On' 197

11. C.S. Lewis: You Don't Need Eyes to See, You Need Vision 227

12. J.K. Rowling: 'It is Our Choices... that Show Us What We Truly Are' 262

Conclusion: 'I Think Lots of Kids Like Monsters' 287

Bibliography: Primary Material $\quad$ · 293

Bibliography: Secondary Material 297 


\section{ACKNOWLEDGEMENTS}

There are very many people to whom both this thesis and I owe a substantial debt of thanks. Neither of us would have come this far had it not been for the encouragement and support shown to us by the staff and postgraduate students of the University of Wales Swansea's Department of English. Likewise, our work together could not have been pursued without the financial investment made in us by the trustees of the Swansea Further Education Trust Fund and the Thomas \& Elizabeth Williams Scholarships. We have benefited mutually from the resources and the expertise of the staff at the Bodleian Library, Cambridge University Library, St Anne's College Library, the University of Wales Swansea Library, the University of York Library, and York Minster Library.

Within the University of Wales Swansea, I extend my especial thanks to Mr Glyn Pursglove for supervising my work during the past three years with dedication, humour, and patience, and for helping me maintain a consistently tight rein over its frequently unruly tendencies. I should also like to acknowledge the contributions made to this project by Prof. Ann Heilmann (now of the University of Hull) and Dr Steven Vine. Outside the University, I am indebted to the Rt Revd Anthony Pierce for keeping me supplied with contemporary cultural media to bolster my thinking around my subject area. I am also obliged to the Revd Kenneth Padley for his unbiased and critically rigorous readings of my work, without which I would feel a lot less confident of its standard than I now do.

My recognition is due to the staff and students of Gorseinon College for providing me with a thesis-free work environment in which I could be a human being rather than an aspirant academic. For friendship (intellectual and otherwise) beyond the bounds of serious coffee drinking, I salute and esteem Dr Alexandra Clarke.

This thesis would not exist if it were not for the love and approbation shown to both it and me by Miss Lana Sheridan during the periods of its inception and gestation. Lana's belief in me and in the value of my work throughout the many times when I believed in neither was inspirational. This project stands as a testament to her confidence that I had an academic potential to fulfil. I trust that it is worthy. 
Peter and Felicity: for everything 


\section{ABBREVIATIONS}

The first instance of each text quoted or referred to in this thesis will be accompanied by a full footnote citation. Texts to which reference is made more than once will thereafter be abbreviated as follows:

AA Martin Gardner, in Lewis Carroll, The Annotated Alice: Alice's Adventures in Wonderland and Through the Looking-Glass, ed. Martin Gardner, rev. edn (London: Penguin Books, 1970).

$A B \quad$ Andrew Birkin, J.M. Barrie \& the Lost Boys (London: Constable, 1979).

AT Alexander L. Taylor, The White Knight: A Study of C.L. Dodgson (Lewis Carroll) (Edinburgh: Oliver \& Boyd, 1952).

$B A \quad$ Brian Alderson, 'Introduction,' in $C K$, ix-xxix.

BF Barbara Freeman, 'Frankenstein with Kant: A Theory of Monstrosity, or the Monstrosity of Theory,' Substance, 52 (1987), 21-31.

$C B$ Clive Barker, in Douglas E. Winter, Clive Barker: The Dark Fantastic (London: HarperCollinsPublishers, 2002).

CK Charles Kingsley, The Water-Babies, ed. Brian Alderson (Oxford: Oxford University Press, 1995).

$C L$ Chantel Lavoie, 'Safe as Houses: Sorting and School Houses at Hogwarts,' in GA, 35-49.

$C P$ Jacqueline Rose, The Case of Peter Pan, or the Impossibility of Children's Fiction (Philadelphia: University of Pennsylvania Press, 1993).

CR Chris Routh, "Man for the Sword and for the Needle She:" Illustrations of Wendy's Role in J.M. Barrie's Peter and Wendy,' Children's Literature in Education, 32.1 (2001), 57-75.

CS J.K. Rowling, Harry Potter and the Chamber of Secrets (London: Bloomsbury, 1998).

CT Rowan Williams, On Christian Theology (Oxford: Blackwell Publishers, 2000).

DH David Holbrook, The Skeleton in the Wardrobe: C.S. Lewis's Fantasies: A Phenomenological Study (London: Associated University Presses, 1991).

$D K$ Don W. King, 'The Childlike in George MacDonald and C.S. Lewis,' Mythlore, 12 (1986), 17-22, 26, http://cslewis.drzeus.net/papers/childlike.html

$D S$ Deborah Stevenson, 'Sentiment and Significance: The Impossibility of Recovery in the Children's Literature Canon or, the Drowning of The Water-Babies,' The Lion and the Unicorn, 21 (1997), 112-30. 
EB Edmund Burke, A Philosophical Enquiry into the Origin of Our Ideas of the Sublime and Beautiful, in Edmund Burke, "A Philosophical Enquiry into the Origin of Our Ideas of the Sublime and Beautiful" and Other Pre-Revolutionary Writings, ed. David Womersley (London: Penguin Books, 1998), 49-199.

EC C.S. Lewis, Essay Collection and Other Short Pieces, ed. Lesley Walmsley (London: HarperCollinsPublishers, 2000).

EG Elaine L. Graham, Representations of the Post/Human: Monsters, Aliens and Others in Popular Culture (Manchester: Manchester University Press, 2002).

FF Mary Martha Sherwood, The History of the Fairchild Family; or, the Child's Manual: Being a Collection of Stories Calculated to Shew the Importance of a Religious Education (London: [printed for] J. Hatchard, 1818).

FH Sarah Trimmer, Fabulous Histories: Designed for the Instruction of Children; Respecting Their Treatment of Animals (London: [printed for] J. Longman, et al., 1786).

FL Florence Becker Lennon, Victoria Through the Looking-Glass: The Life of Lewis Carroll (New York: Simon and Schuster, 1945).

GA Giselle Liza Anatol, ed., Reading Harry Potter: Critical Essays, (London: Praeger, 2003).

GE Sarah Trimmer, The Guardian of Education: A Periodical Work, intro. Matthew Grenby, 5 vols (Bristol / Tokyo: Thoemmes Press / Edition Synapse, 2002).

GG George Warren Gignilliat, The Author of Sandford and Merton: A Life of Mr. Thomas Day, Esq. (New York: Columbia University Press, 1932).

GM George MacDonald, At the Back of the North Wind / The Princess and The Goblin / The Princess and Curdie (London: Octopus Books, 1979).

HB J.K. Rowling, Harry Potter and the Half-Blood Prince (London: Bloomsbury, 2005).

HC Humphrey Carpenter, Secret Gardens: A Study of the Golden Age of Children's Literature (Boston: Houghton Mifflin Company, 1985).

HP [Anna Laetitia Barbauld,] Hymns in Prose for Children by the Author of Lessons for Children (London: [printed for] J. Johnson, 1781).

IA Peter J. Schakel, Imagination and the Arts in C.S. Lewis: Journeying to Narnia and Other Worlds (Columbia: University of Missouri Press, 2002).

IK Immanuel Kant, Critique of the Power of Judgment, ed. Paul Guyer, trans. Paul Guyer \& Eric Matthews (Cambridge: Cambridge University Press, 2000).

JC Jeffrey Jerome Cohen, 'Monster Culture (Seven Theses),' in Monster Theory: Reading Culture, ed. Jeffrey Jerome Cohen (Minneapolis: University of Minnesota Press, 1996), 3-25. 
$J G \quad$ Jennifer Geer, “'All sorts of pitfalls and surprises:” Competing Views of Idealized Girlhood in Lewis Carroll's Alice Books,' Children's Literature, 31 (2003), 1-24.

JM James Holt McGavran, ed., Romanticism and Children's Literature in NineteenthCentury England (Athens, Georgia: University of Georgia Press, 1991).

JP John Pridmore, 'Modern Myths of Good \& Evil,' St Martin in the Fields - Church, http://www2.stmartin-in-the-

fields.org/page/church/sermons/Oct\%2030\%2005\%20JP.pdf

JR Jean-Jacques Rousseau, Émile, trans. Barbara Foxley (London: J.M. Dent, 1993).

JT Janet Todd, Sensibility: An Introduction (London: Methuen \& Co., 1986).

$K G \quad$ J.M. Barrie, Peter Pan in Kensington Gardens, in $P \& P, 1-65$

KL Kathleen Kelley-Lainé, Peter Pan: The Story of a Lost Childhood (Shaftesbury, Dorset: Element, 1997).

LB C.S. Lewis, The Last Battle: A Story for Children (Harmondsworth: Penguin, 1964).

LC Lewis Carroll, Alice's Adventures in Wonderland; Through the Looking-Glass, ed. Roger Lancelyn Green (Oxford: Oxford University Press, 1998).

LC2 [Anna Laetitia Barbauld,] Lessons for Children, from Two to Three Years Old (London: [printed for] J. Johnson, 1787).

LC3 [Anna Laetitia Barbauld,] Lessons for Children, of Three Years Old. Part I [II], 2 vols (Dublin: R. Jackson, 1779).

LF Leona W. Fisher, 'Mystical Fantasy for Children: Silence and Community,' The Lion and the Unicorn, 14 (1990), 37-57.

LM Lisa Hermine Makman, 'Child's Work is Child Play: The Value of George MacDonald's Diamond,' Children's Literature Association Quarterly, 24.3 (1999), 119-29.

LS Lawrence Stone, The Family, Sex and Marriage in England 1500-1800, abr. edn (London: Penguin, 1990).

LW C.S. Lewis, The Lion, the Witch \& the Wardrobe: A Story for Children (Harmondsworth: Penguin, 1959).

MA Markman Ellis, The Politics of Sensibility: Race, Gender and Commerce in the Sentimental Novel (Cambridge: Cambridge University Press, 1996).

MD William McCarthy, 'Mother of All Discourses: Anna Barbauld's Lessons for Children,' Princeton University Library Chronicle, 60.2 (Winter 1999), 196-219, http://ccl.princeton.edu/index.php?app $=$ download\&id $=100$ 
ME Maria Edgeworth, Letters for Literary Ladies, ed. Claire Connolly (London: J.M. Dent, 1993).

$M G \quad$ Matthew Grenby, 'Introduction,' in $G E$, I, v-xli.

MK Margaret Kinnell, 'Publishing for Children 1700-1780,' in Children's Literature: An Illustrated History, ed. Peter Hunt (Oxford: Oxford University Press, 1995), 2645 .

ML Mark Loveridge, 'The Water-Babies' (unpublished lecture notes, University of Wales Swansea, n.d.).

MS Mary Martha Sherwood, The Life of Mrs. Sherwood, (Chiefly Autobiographical) with Extracts from Mr. Sherwood's Journal During His Imprisonment in France and Residence in India, ed. Sophia Kelly (London: Darton \& Co., 1854).

NA Nina Auerbach, 'Alice and Wonderland: A Curious Child,' Victorian Studies, 17 (1973), 31-47.

NE Paul A. Karkainen, Narnia Explored (Old Tappan, New Jersey: Fleming H. Revell Company, 1979).

NI Michael Egan, 'The Neverland of Id: Barrie, Peter Pan, and Freud,' Children's Literature, 10 (1982), 37-55.

NW George MacDonald, At the Back of the North Wind, in GM, 5-292.

OED Oxford English Dictionary, http://www.oed.com

OP J.K. Rowling, Harry Potter and the Order of the Phoenix (London: Bloomsbury, 2003).

P\&P J.M. Barrie, Peter Pan in Kensington Gardens \& Peter and Wendy, ed. Peter Hollindale (Oxford: Oxford University Press, 1991).

PA J.K. Rowling, Harry Potter and the Prisoner of Azkaban (London: Bloomsbury, 1999).

PC C.S. Lewis, Prince Caspian: The Return to Narnia (Harmondsworth: Penguin, 1962).

PF Paul D. Ford, Companion to Narnia, 4th edn (New York: Harper San Francisco, 1994).

$P G$ George MacDonald, The Princess and the Goblin, in GM, 295-458.

POP J.M. Barrie, Peter Pan and Other Plays, ed. Peter Hollindale (Oxford: Oxford University Press, 1995).

PP J.M. Barrie, Peter Pan, or the Boy Who Would Not Grow Up, in POP, 73-154.

PS J.K. Rowling, Harry Potter and the Philosopher's Stone (London: Bloomsbury, 1997). 
$P W \quad$ J.M. Barrie, Peter and Wendy, in $P \& P, 67-226$.

QL Q.D. Leavis, 'The Water-Babies,' Children's Literature in Education, 23 (1976), 155-63.

RE Richard Lovell Edgeworth \& Maria Edgeworth, Memoirs of Richard Lovell Edgeworth, Esq., 2 vols (London: [printed for] R. Hunter, 1820), I.

$R G \quad$ Roger Lancelyn Green, Fifty Years of Peter Pan (London: Peter Davies, 1954).

RH Peter J. Schakel, Reading with the Heart: The Way into Narnia (Grand Rapids, Michigan: William B. Eerdmans Publishing Company, 1979).

$R W \quad$ Robert Lee Wolff, The Golden Key: A Study of the Fictions of George MacDonald (New Haven: Yale University Press, 1961).

SC Samuel Taylor Coleridge, Collected Letters of Samuel Taylor Coleridge, ed. Earl Leslie Griggs, 6 vols (Oxford: Clarendon Press, 1956), I.

SF Sigmund Freud, 'The "Uncanny" (1919),' trans. Alex Strachey, in Sigmund Freud, Collected Papers, Authorized Translation Under the Supervision of Joan Riviere, 5 vols (London: The Hogarth Press, 1950), IV, 368-407.

SJ Samuel Johnson, in James Boswell \& Samuel Johnson, Boswell's Life of Johnson Together with Boswell's Journal of a Tour to the Hebrides and Johnson's Diary of a Journey into North Wales, ed. George Birkbeck Hill, rev. L.F. Powell, 6 vols (Oxford: Clarendon Press, 1934).

TD Thomas Day, The History of Sandford and Merton, $5^{\text {th }}$ edn, 3 vols (London: [printed for] John Stockdale, 1790).

TT Tzvetan Todorov, The Fantastic: A Structural Approach to a Literary Genre, trans. Richard Howard (Ithaca, New York: Cornell University Press, 1975).

$T W \quad$ C.S. Lewis, 'Of Three Ways of Writing for Children,' in EC, 505-15.

UK U.C. Knoepflmacher, Ventures into Childland: Victorians, Fairy Tales, and Femininity (Chicago: University of Chicago Press, 1998).

VC Valentine Cunningham, 'Soiled Fairy: The Water-Babies in its Time,' Essays in Criticism, 35 (1985), 121-48.

$V D$ C.S. Lewis, The Voyage of the Dawn Treader: A Story for Children (Harmondsworth: Penguin, 1965).

WA W.H. Auden, Forewords and Afterwords, selected by Edward Mendelson (London: Faber \& Faber, 1973).

WM Walter de la Mare, Lewis Carroll (London: Faber and Faber, 1932). 
From childhood's hour I have not been

As others were - I have not seen

As others saw - I could not bring

My passions from a common spring.

From the same source I have not taken

My sorrow; I could not awaken

My heart to joy at the same tone;

And all I lov'd, $I$ lov'd alone.

Then - in my childhood - in the dawn

Of a most stormy life - was drawn

From ev'ry depth of good and ill

The mystery which binds me still:

From the torrent, or the fountain,

From the red cliff of the mountain,

From the sun that 'round me roll'd

In its autumn tint of gold -

From the lightning in the sky

As it pass'd me flying by -

From the thunder and the storm,

And the cloud that took the form

(When the rest of Heaven was blue)

Of a demon in my view.

(Edgar Allan Poe ${ }^{1}$ )

'Edgar Allan Poe, 'Alone,' 1, in The Collected Tales and Poems of Edgar Allan Poe (New York: Modern Library, 1992). 
INTRODUCTION 
In his recent biography of the fantasy author Clive Barker, Douglas E. Winter quotes Barker as saying that 'I think lots of kids like monsters." This simple subjective statement and its context, though far from being the initial inspiration for this thesis, have nevertheless become a neat encapsulation of the rationale behind it. At the point in Winter's book from which this comment is taken, Barker is discussing his childhood as one who was an imaginative dreamer, as one who had imaginary friends, and as one who drew monsters. Winter implicitly associates these traits with the children's stories - including works by J.M. Barrie, Kenneth Grahame, and Beatrix Potter - that were read to the young Barker by his mother. The influence of these writers on Barker is considerable. They define the child that he was and the man that he is, such that, even now, he confesses to an ongoing enamourment with Barrie: '[Peter Pan is] the book I want to be buried with' $(C B$, p. 15).

Barker is one among many in being influenced by the literature to which he had access as a child, since childhood experiences objectively contribute to one's eventual life as an adult. This is not the only point that Winter's text is making here however. More important to him is the juxtaposition of three popular authors of children's literature with the idea of in-text monstrosity, in tandem with the unspoken suggestion that monstrosity was and is something formatively important in Barker's life and in the lives of children more generally. These propositions, at first glance, seem deeply troublesome. Where, for example, are the monsters in Potter's children's literature? Barrie and monsters, yes; Grahame and monsters, perhaps; but Potter and monsters... well, no. More to the point, how can monsters - creatures that are, by definition, evil, wicked, and distorted - possibly have any constructive impact upon the lives of those who interact with them? Monsters are bad. The only positive influence that they could conceivably have upon their audience would be to teach by negative association.

\footnotetext{
2 Clive Barker, in Douglas E. Winter, Clive Barker: The Dark Fantastic (London: HarperCollinsPublishers, 2002), hereafter $C B$, p. 13.
} 
Responses such as these are caricatured oversimplifications, and it is partly to the processes of unpacking and refuting approaches like them that this project is dedicated. Monstrosity certainly has a notably high incidence - even an inherence - in children's literature, but its presence is not necessarily to be found in the evil, the wicked, and the distorted. These terms represent only one aspect of monstrosity's existence as the primary contributor to a discourse of difference, alienation, and otherness, in which children - and hence children's literature - are intrinsically implicated. This thesis will utilize this discourse by developing a theoretical framework around the notion of monstrosity - though not bound solely to monstrosity's direct linguistic cognates - in relation to (the genesis of) English children's literature. This structure will then be used as a tool with which to dissect and analyse popular texts from across the canon of English writing for children. The critique produced will document, in case study form, a quarter of a millennium of English approaches to children as readers, as literary figures, and as monsters.

In the realization of this enterprise, a number of methodological constraints have been introduced to make its vast scope more manageable. The decision to privilege the Englishness of the children's texts being examined here results from the cohering logic of studying primary material that is taken from within relatively well defined cultural and geographical boundaries. There is no inconsistency between this and the use of texts in the initial theoretical discussion that originate from both English and non-English backgrounds, because, quite simply, a number of the treatises that best describe monstrosity and the notions that surround it are written in languages other than English. Where such texts are dealt with, English translations of them are used to which critical credence seems to be attributed most consistently in secondary sources. Thus, this study will privilege the analysis of English children's literature in relation to an international (and hence universally recognizable) critical discourse. This is not to suggest that said dialectic is not applicable to non-English 
children's literature or even literature more generally. It is just that, on this occasion, these aspects of its application will not be developed.

The presentational format of author-by-author - or, more usually, text-by-text - case studies is apposite here for a number of reasons. Individual focus on specific works by specific authors will permit this study to adapt as appropriate to the separate requirements of each case. For example, in discussing some of the now lesser known authors of early children's literature, the inclusion of biographical or other contextual material may be suitable where it would not be in the discussion of better known contemporary writers: there is no point in replicating information which is already widely available, whereas material which is more obscure naturally demands more directed attention. A clearly defined text-bytext methodology allows for such adjustments, whilst simultaneously facilitating a tight locus of textual criticism that would swiftly become dispersed through an attempt to treat the subject matter as constituent parts of (arbitrarily) imposed chronological or thematic groups. Some authors, admittedly, might respond well to such handling. Charles Kingsley, Lewis Carroll, and George MacDonald, writing within the same decade, all inject a distinct shot of fantastical imagination into their children's literature (especially in comparison to the relatively dry didacticism of their late eighteenth- and early nineteenth-century predecessors) that could arguably justify a grouped study of their work against such a background. However, for too many of the texts being investigated here, a comparable approach would be more of an abstract distraction than it would an intellectual assistance, and so it will not be used. The only ordering that is applied to this material is, generally, chronological by date of publication. This maintains the logical suggestion of historical evolution, without involving any potentially misrepresentative or misleading sectionalization. On those few occasions when it is necessary for this ordering to be disrupted, an explanation for the disturbance is provided. 
What, then - to draw us forward - are monsters? From what and from where does monstrosity come? Why do monsters exist? What, if anything, is their function? These are all questions that haunt children's literature, the idea of childhood, and children themselves. Their implications are, for some, too problematic to manage. Barker, commenting on the cuts to his film Nightbreed that were demanded by the Motion Picture Association of America, says that:

Thematically the movie just got up people's noses. There were people who said - and they actually said this to me - You can't make the monsters the good guys. You can't do it. And we're going to be hard on this movie because the monsters are the good guys.

$$
\text { ( } C B \text {, p. 323) }
$$

The palpable contempt of Barker's tone reveals the extent to which he disagrees with the MPAA's assessments of his work. For him, monsters clearly can be the good guys, or, perhaps more significantly, need not necessarily be the bad guys. Indeed, Barker's impression of monsters - born, remember, from readings of children's literature - resists the reductive terminology of good versus evil. Instead, for Barker, monsters heal:

[Stephen King's] stories are healing stories in a way that mine aren't... King heals to a great extent by dealing with the monsters as though they were alien. I heal by having characters realize that the monsters are part of themselves.

$(C B$, p. 160)

Monsters that heal, whether through alienation or internalization, are apparently beyond the conceptualization of the MPAA, and probably also beyond the range of meaning that most would normally associate with the notion of monstrosity. In fact, these two observations are directly related, since it is the atypical beyondness of Barker's perception of monstrosity that prevents the MPAA from seeing what his Nightbreed monsters are about. The problem of monstrosity's semantics has recurred, reiterating the need for a wider examination of it. 
This, therefore, and the immediacy of its relevance to children's literature, will comprise this project's first chapter.

I, like Clive Barker, think lots of kids like monsters for the empirical reason that there are lots of monsters in kids' literature. I also think that lots of kids like monsters in literature because monsters help kids understand the version of their social environment that is rendered in what they read and have read to them. It is the questions of what these monsters are and how they function that this thesis will address. 


\section{CHAPTER ONE}

MONSTROUS CHILDREN: THE DISCOURSE OF THE DIFFERENT 


\section{(i) Origins}

According to the Oxford English Dictionary, ${ }^{3}$ the oldest etymological relative of the Modern English noun monster is the Latin monstrum, which translates variously as 'portent, prodigy, monstrous creature, wicked person, monstrous act, atrocity.' (OED) Barbara Freeman, who includes a brief paragraph on monster's etymology in her 'Frankenstein with Kant: A Theory of Monstrosity, or the Monstrosity of Theory,' agrees with this assessment, and lays especial emphasis on the prophetic as the most crucial interpretation of monster's Latinate predecessor. ${ }^{4}$ She also homes in upon the contextual relevance of the French monstre and goes on to state that:

What is important here... is that the French monstre (a relative of montrer, to show) was once in English a now obsolete form of monster, and meant both something huge or enormous, and a demonstration or proof, something shown or exhibited. A whole family of English words reflects this conjunction: monstrable means capable of being shown; monstrance means demonstration or proof; to monstrate is to prove; a monstration means a demonstration; and the archaic verb to monster meant to exhibit or point out.

$$
(B F, \text { p. 27) }
$$

In short, for Freeman, the Modern English monster derives ultimately from two sources: the Latin monstrum (a physical, psychological, or notional abnormality) and the French monstre (the act of showing or something that shows). By comparison, although the $O E D$ acknowledges the etymological influence of the French monstre on the Modern English monster, it notably does not play up the link between monstre and montrer that is identified by Freeman. The $O E D$ 's definition of monster therefore favours meanings that derive from monstrum, and emphasizes decidedly less than Freeman monster's potential capacity for showing.

\footnotetext{
${ }^{3}$ Oxford English Dictionary, http://www.oed.com, hereafter $O E D$. The $O E D$ 's online subscription service currently comprises, in its majority, data taken from the 20 volume second edition of 1989. Pagination to a physical edition is not provided by the online service and is therefore not offered here.

${ }^{4}$ Barbara Freeman, 'Frankenstein with Kant: A Theory of Monstrosity, or the Monstrosity of Theory,' Substance, 52 (1987), 21-31, hereafter $B F$ (p. 27).
} 
A plausible resolution for the disparity between these two definitions can be found by examining the $O E D$ 's etymology of the now rare English verb to monstrate - identified by Freeman as one of monster's cognates - which means to show. The past participle form of the Latin monstrare, also meaning to show, is included in monstrate's etymology, and, orthographically, monstrare looks convincingly like a Latinate root for both monstre and montrer. This intertwining relationship, which provides a Latin source for Freeman's monstre and montrer, and which explains her association of them with the act of showing, ultimately lends credence to her rounded definition of monster by comparison to the $O E D$ 's slightly more biased account. It is not just monstrum that is important here. Monstrare, via French, also has its part to play.

In reduction, then, there are two Latinate etymological roots that are focal to a discussion of the Modern English monster: monstrum and monstrare. Monstrum gravitates towards a meaning associated with anomaly (portent being the only defining term used by the $O E D$ which arguably deviates from this understanding), whereas monstrare leans towards the idea of revelation. The co-evolution of these terms - especially, it seems, through French - has resulted in an exchange of semantic material between them. This, in turn, has led in Modern English to a series of monster-related words that now encompass the full range of meaning that was possessed by their two Latin originators.

There is, however, a distinct problem with these English cognates, inasmuch as some of them which appear to be antonymous actually function synonymously. Take, for example, the Modern English demonstration. Freeman uses demonstration in her essay as a clearly defined term of translation: 'monstrance means demonstration;' 'a monstration means a demonstration.' ( $B F$, p. 27) Focussing on the latter of these, both monstration and demonstration have Latin origins as nouns of action taken from monstrare and demonstrare, respectively. They have also, according to $O E D$, existed synonymously since their inception. 
Yet the Latin prefix de-normally operates, in exactly the same way as it has come to do in Modern English, to negate the term to which it is applied, in which case monstrare and demonstrare should logically exist as antonyms. Why do they not?

The rational answer is to be found, once again, in the dialogue between monstrum and monstrare. Hitherto, we have considered these to be two distinct terms, of which the meanings became blended during their incorporation into Modern English. However, the monstration / demonstration example suggests that the semantics of monstrum and monstrare may actually have been fluid since their Latinate usage. If demonstrare is the Latinate root of the Modern English demonstration, where demonstrare is the negated form of monstrare (to show), then demonstration should be defined in terms of such concepts as concealment and occlusion. In other words, if this is the case, demonstration should be used in opposition to the way in which it is normally used in Modern English. However, if we consider demonstrare to be the negated form of monstrare, where monstrare is a term that is additionally semantically beholden to monstrum (which is associated with notions of wickedness, anomaly, prodigy, and atrocity), then the meaning of the Modern English demonstration must again shift accordingly. In this instance, the idea of demonstration would become linked as well with the processes of normalization, naturalization, and explication. It would become a word coterminous with what could be thought of as demonsteration, which, in effect, is exactly what it now is. A demonstration is that which takes something hidden, strange, in need of explanation, difficult to comprehend, or even beyond comprehension, and makes it available - in a way that it was not before - to a perceiving subject.

What all this material shows, in short, is that the etymology of monster and its cognates lends them a dual function as things that are to be feared and as things that show. These two features are inherently linked and their notional separation should not be attempted, 
particularly since a number of other contextually relevant Modern English terms follow different evolutionary routes to comparable semantic multiplicity. The Latin spectare (to look) provides the etymological root of both the Modern English spectre and spectacle. $(O E D)$ Spectre describes an image or phantom, and is usually a thing that frightens. Spectacle is an exhibition, display, or - in its plural form - an optical device to improve sight. Similarly, the Greek paivelv (to show) is related variously to the Modern English phantom (via phantasma), fantasy, fantastic, and epiphany. (OED) All four of these modern terms in some way connote the superhuman but epiphany does so with specific reference to the manifestation, the showing, the revelation of the superhuman (its most common usage is as the proper noun name of the Christian festival at which Christ appeared to the Gentiles).

\section{(ii) Modifications}

The dual presence in all these terms of fear and vision is as remarkable as it is consistent, and it demands from us a particular intellectual response. It suggests that, whenever faced with an object that unnerves as a result of its monstrosity, the perceiving subject must always query that object to ask what its monstrosity reveals. Why is that object a monster? What does the monster show? The answers to these questions are unlikely to be straightforward, particularly since monstrosity's semantic doubleness (as we have seen both in its etymology and in the worked example of demonstration) permits it to exist paradoxically as both itself and the opposite of itself, but they must be sought nevertheless. Indeed, some critics privilege this paradoxical oppositional presence as the best means by which to refine definitions of monstrosity, and thereby establish their notions of it through opposition to a polarizing other. In the first chapter of Monsters in English Literature: From the Romantic Age to the First World War, Paul Goetsch manufactures an effective five part classification 
of monster by antagonizing the notions of hero set out by Northrop Frye in Anatomy of

\section{Criticism:}

1. In myths the hero is far superior to other men and the environment they inhabit; as a divine or semi-divine being, he faces equally powerful monsters...

2. In romance-like works... the hero is identified as a human being, but is superior to other men as well as his environment... He is confronted with monsters which, like aliens from other planets, are clearly different from human beings in the reader's or spectator's world...

3. In the "high mimetic mode" (epic poems and tragedies) the hero is "superior in degree to other men but not his natural environment"... If his antagonist is a monster... it represents a romance-like alien world, with laws of its own. Hence, its nonhuman features are clearly marked...

4. In the "low mimetic mode" (comedies, modern novels) the hero is "one of us," a human being "superior neither to other men nor to his environment." Correspondingly, monsters in such works are depicted as human beings with some features that are labelled as monstrous.

5. In the ironic mode... the protagonist is "inferior in power or intelligence to ourselves." Concomitantly, the monstrous elements are reduced and employed for comic and satiric, rather than for terrifying, effects. ${ }^{5}$

In this sequence, Goetsch identifies two different types of monsters that will appear under different circumstances. The more a text favours a realistic mode, the more likely it is that any monsters in it will be identified either metaphorically or in the particular features of its human characters. By comparison, the more a text favours a fantastical mode, the more likely it is that any monsters in it will appear personified in usually non-human figures.

This typical segregation is useful, because it offers an explanation for monstrosity's divergent presence within different literary modes, but it is also flawed. Monster, we have discovered from its etymology, exists concurrently as itself and the opposite of itself, and it cannot, therefore, be defined through opposition alone, which is what Goetsch is doing. For Goetsch, the essential precursor to the existence of monster is the notion of hero, against which monster may be set in polarity. Monster, for Goetsch, is anti-hero and evil, but this -

\footnotetext{
${ }^{5}$ Paul Goetsch, Monsters in English Literature: From the Romantic Age to the First World War (Frankfurt am Main: Peter Lang, 2002), pp. 7-8.
} 
in the context of monster's etymology - is an oversimplification. Certainly, monsters can be anti-heroes and they can be evil, but these are not features that exclusively fix them.

Establishing, however, that monsters should not be defined solely in terms of either good and evil, or hero and anti-hero, still leaves behind the question of what should be thought about them. The answer to this is to be found in that which is different to a subjective perception of normalcy:

One of the ways in particular in which the boundaries between humans and almosthumans have been asserted is through the discourse of "monstrosity." Monsters serve both to mark the fault-lines but also, subversively, to signal the fragility of such boundaries. They are truly "monstrous" - as in things shown and displayed - in their simultaneous demonstration and destabilization of the demarcation by which cultures have separated nature from artifice, human from non-human, normal from pathological. Teratology, the study of monsters, bears witness to this enduring tradition of enquiry into the genesis and significance of the aw(e)ful prospect of human integrity transgressed. ${ }^{6}$

Elaine Graham's insistence here upon monstrosity's duality is essential. Monsters mark out the boundaries of normal humanity whilst simultaneously signalling their fragility. They demarcate as they destabilize and vice versa. The subversion of defined familiarity as an imperative in the discourse of monstrosity is implied in the subtitle to the book from which this extract is taken - Monsters, Aliens and Others in Popular Culture - through the juxtaposition of monsters with aliens. To be alien is to be outside or different, but is not necessarily to suffer the moral abjection normally associated (whether consciously or not) with monster. Alien describes other. Monster describes other where other starts to impinge on what is, for want of a better phrase, non-other: 'monsters stand at the entrance to the unknown, acting as gatekeepers to the acceptable.' ( $E G$, p. 53) Again, this is not to say that either monsters or that which they guard is inherently evil, for that which is unknown and

\footnotetext{
${ }^{6}$ Elaine L. Graham, Representations of the Post/Human: Monsters, Aliens and Others in Popular Culture (Manchester: Manchester University Press, 2002), hereafter EG, p. 12.
} 
unacceptable is not necessarily bad. It is, though, to assert the power of monstrosity's terror, through the observation that, in the transition from alien to monster:

A slippage occurs. Difference becomes deviance (as measured against a hegemonic norm) which becomes equated with other pathologies in a process of scape-goating. The qualities of subordinate groups are unfavourably compared with those of the dominant group, and become self-fulfilling prophecies of exclusion and subjugation.

(EG, p. 53)

Monster, therefore, is a subjective term of variable power, of which the adjudged strength increases in direct proportion to the increase of an operating object's transgressive impositions upon a perceiving subject. Or, rather, the strength of a subject's ascription of monstrosity to an object increases in direct proportion to the subject's perception of being imposed upon by it.

That monstrosity is intrinsically personal is an especially important point. Understandings of normality change from place to place, from culture to culture, and from individual to individual. Understandings of normality are fundamentally subjective. Monstrosity occurs at the point at which normality is threatened or transgressed, and must therefore be beholden to subjective understandings of normality. This contextually crucial privileging of the subject might seem to be yet another hurdle to be jumped in the process of defining monstrosity, because it increases rather than reduces monstrosity's semantic flexibility. However, it actually works to the definer's advantage as well, by exploding monstrosity into the territory of a number of other well-established aesthetic theories of subjective transgression. The sublime of Burke and Kant, Freud's uncanny, Todorov's fantastic, in addition to - more generally - the gothic, must all be considered as tributaries to monstrosity's discourse. This list draws together, albeit not exhaustively, some of the principal dialectics developed by some of the foremost recorded critical thinkers in this field. 
These dialectics can be used effectively to impose structure around monstrosity's semantic amorphousness.

To appreciate the sublime, as understood by Edmund Burke, astonishment must first be recognized, where astonishment 'is that state of the soul, in which all its motions are suspended, with some degree of horror. ${ }^{77}(E B$, p. 101) Nothing is as effective as fear at robbing the soul and the mind of their faculties in this way, and so 'terror is in all cases... the ruling principle of the sublime.' ( $E B$, p. 102) That which engenders terror, however, does not automatically give rise to sublimity, because the state of sublimity is dependent upon two additional factors: first, whether or not the terrifying object is posing or can pose an overwhelming threat to the perceiving subject; second, whether or not the terrifying object is imposing or can impose an overwhelming pain on the perceiving subject. The experience of the sublime cannot abject the subject: 'when danger or pain press too nearly, they are incapable of giving any delight, and are simply terrible; but at certain distances, and with certain modifications, they may be, and they are delightful, as we every day experience.' $(E B$, p. 86) The most prominent instigators of fear, for Burke, include obscurity, infinity, power, privation, vastness, and rapid change (e.g., from darkness into light and vice versa or from quietness into noisiness and vice versa). ${ }^{8}$ These stimuli may act alone or in conjunction with each other.

By comparison, for Immanuel Kant, the sublime 'is to be found in a formless object insofar as limitlessness is represented in it." 'What is properly sublime cannot be contained in any sensible form.' (IK, p. 129) 'We call sublime that which is absolutely great,' (IK, p.

\footnotetext{
${ }^{7}$ Edmund Burke, A Philosophical Enquiry into the Origin of Our Ideas of the Sublime and Beautiful, in Edmund Burke, "A Philosophical Enquiry into the Origin of Our Ideas of the Sublime and Beautiful" and Other Pre-Revolutionary Writings, ed. David Womersley (London: Penguin Books, 1998), 49-199, hereafter $E B$ (p. 101). The version of Burke's Enquiry that is included in this collection is the second (1759) edition.

${ }^{8}$ For qualification of these, see $E B$, pp. 102-16.

${ }^{9}$ Immanuel Kant, Critique of the Power of Judgment, ed. Paul Guyer, trans. Paul Guyer \& Eric Matthews (Cambridge: Cambridge University Press, 2000), hereafter $I K$, p. 128.
} 
131) where 'absolute greatness is not greater than the greatest greatness... [but] designates rather that there is, absolutely, greatness. ${ }^{10}$ This approach jars against that of Burke, for whom there are, for example, certain animals which 'though far from being large, are yet capable of raising ideas of the sublime, because they are considered as objects of terror.' ( $E B$, p. 102) Having said which, Burke's sublime does still push towards the absolute greatness which is so important to Kant through the vast conceptual scope of the numerically few stimuli that are able to initiate it. Samuel Monk, in his paraphrase of Kant, provides further material with which to resolve this limited versus limitless disparity between the two:

In experiencing the sublime, the imagination seeks to represent what it is powerless to represent... This effort and this inevitable failure of the imagination are the source of the emotions that accompany the sublime, which achieves its effect by the opposition between the object and our faculties of knowledge... It is upon this lack of harmony between object and subject, upon the futile effort on the part of the imagination to grasp and represent the formless, that Kant erects his theory of the sublime. ${ }^{11}$

To put it another way, the relationship between the physical status of an object and a subject's imaginative perception of it is not necessarily directly correlative. Therefore, an object which is limited may still point a subject's imagination towards the limitless. For example, a mariner on a boat in the middle of an ocean may only be able to see unbroken water in every direction, but this does not mean that the ocean is perpetual. Although it is hard to quantify, scientific delineation of the world's water cycle tells us that the total amount of water that is present in our atmosphere and physical environment is constant, and the ocean's size is therefore limited by implication. However, when surrounded by water and imposed upon by the sea's sheer volume, the latent presence of the sea could conceivably result in the impression of its being infinite, i.e., limitless. Thus, something which is

\footnotetext{
${ }^{10}$ Jean-Luc Nancy, 'The Sublime Offering,' in Jean-François Courtine, et al., Of the Sublime: Presence in Question, trans. by Jeffrey S. Librett, (Albany, N.Y.: State University of New York Press, 1993), 2553 (p. 37).

${ }^{11}$ Samuel H. Monk, The Sublime: A Study of Critical Theories in XVIII-Century England (Ann Arbor: University of Michigan Press, 1960), p. 4.
} 
provably limited may nevertheless appear to be limitless and will therefore be capable of giving rise to a state of sublimity when represented under appropriate circumstances.

These paragraphs are obviously summary, but they still serve the purpose of demonstrating the sublime - as understood by two of its principal exponents - to be an aesthetic condition of transgression and of the self which is thereby closely akin to monstrosity. Both sublimity and monstrosity give rise to fear, both threaten the boundaries of subjective normalcy, and both are bound up with that which is alien, that which is different, and that which it is difficult to get hold of. The uncanny, the fantastic, and the gothic can all be added to or seen as modifications of Burke and Kant's list of sublime - and, apparently, monstrous - stimuli.

The uncanny, as defined by Sigmund Freud, is enmeshed in the semantic possibilities of the German unheimlich, under which title Freud initially presented his research on the subject:

The German word unheimlich is obviously the opposite of heimlich, heimisch meaning "familiar", "native", "belonging to the home"; and we are tempted to conclude that what is "uncanny" is frightening precisely because it is not well known and familiar. Naturally not everything which is new and unfamiliar is frightening, however; the relation cannot be inverted. ${ }^{12}$

From the meaning range that Freud gives to the German heimlich, it is clear that he is keen to point out that the word's negated form cannot and should not be interpreted solely as meaning 'new and unfamiliar.' Instead, an understanding of unheimlich must also take into account the term's literal rendering, i.e., unhomely or, and this subtle change of emphasis is extremely important, not at home. For Freud, the uncanny - where uncanny is the now ubiquitous English translation of Freud's unheimlich - is frightening because it embodies the new, the unfamiliar, the unhomely, and the not at home. It is a vehement discourse of

\footnotetext{
${ }^{12}$ Sigmund Freud, 'The "Uncanny" (1919),' trans. Alex Strachey, in Sigmund Freud, Collected Papers, Authorized Translation Under the Supervision of Joan Riviere, 5 vols (London: The Hogarth Press, 1950), IV, 368-407, hereafter $S F$ (p. 370).
} 
alienation and difference, which 'undoubtedly belongs to all that is terrible - to all that arouses dread and creeping horror.' $(S F$, p. 368)

It is interesting to note, though, that after a series of determined assertions on the subject, Freud backtracks on his description of the uncanny by revealing that 'it is equally certain... that [the uncanny] is not always used in a clearly definable sense, so that it tends to coincide with whatever excites dread.' (SF, p. 368) That which, in one breath, undoubtedly belonged to all that aroused dread is in the next only tending to coincide with it, and Freud's definition of the uncanny subsequently becomes defined by its indefiniteness: '[it] becomes uncanny because [its] attempts to define the uncanny begin to collapse in strangely uncanny ways. ${ }^{, 13}$ This indefinition, of course, is at least in part the point, because Freud's written methodology starts to act as an extended metaphor for one of the foremost phenomena that contributes to the uncanny's construction, i.e., obscurity (remembering that obscurity was on Burke's list of sublime inducing factors). The obscurity of the uncanny is of a particular sort that turns upon the not-at-home translation of the German unheimlich. It is of a type that returns into the home, into the normal, into the established, to threaten them with its not-at-homeness, its abnormality, and its disestablishment. It worries the subject by drawing boundaries of normality and then stepping over them, by being that with which the subject should be in touch and able to control and yet is not and cannot. It is, as David Punter has it, almost like an aesthetically heightened sense of déjà $v u$ :

What does this mean? What does "déjà vu" mean? What could it possible mean to have a false sense of déjà vu, whereby one only imagines one has "been here before", when that is the very structure of déjà vu in the first place (if there is a first place)? ${ }^{14}$

\footnotetext{
${ }^{13}$ Andrew Smith, Gothic Radicalism: Literature, Philosophy and Psychoanalysis in the Nineteenth Century (London: Macmillan Press, 2000), p. 150.

${ }^{14}$ David Punter, 'Shape and Shadow: On Poetry and the Uncanny', in A Companion to the Gothic, ed. David Punter (Oxford: Blackwell Publishers, 2000), 193-205, (p. 195).
} 
The uncanny, then, inhabits that special sort of obscurity that is known and yet cannot be known, that is of the home and yet is not at home. It is a transgression from within. It is a transgression of the self by the self.

Tzvetan Todorov's fantastic occupies a similar territory to Freud's uncanny, as it delineates the hesitating moment when borders break down between the real and the literary or between fact and fiction: 'the fantastic occupies the duration of this uncertainty., 15

'I nearly reached the point of believing': that is the formula which sums up the spirit of the fantastic. Either total faith or total incredulity would lead us beyond the fantastic: it is hesitation which sustains its life.

$$
(T T, \text { p. 31) }
$$

Lucie Armitt sees Todorov's fantastic as the essential median between the (arguably) separate modes of the uncanny and the gothic:

In many ways it is the gothic, of all fantasy modes, that forms the closest parallel with Todorovian readings of the fantastic. Structured around the discourse of the uncanny, unlike the defamiliarizations of science fiction this world has invaded our own to fracture and disrupt the reassuring presence of inner worlds. ${ }^{16}$

From this, the gothic is constituted upon the prospect of uncanny terror in combination with the fantastic's hesitation over the unfixable distance between actual and textual (un)realities: 'gothic [signifies] a trend towards an aesthetic based on feeling and emotion and associated primarily with the sublime., 17

Thus, a brief trek through the realms of the uncanny, the fantastic, and the gothic, returns to its starting point by restating the contextual value of sublimity, ${ }^{18}$ and it is sublimity at the

\footnotetext{
15 Tzvetan Todorov, The Fantastic: A Structural Approach to a Literary Genre, trans. Richard Howard (Ithaca, New York: Cornell University Press, 1975), hereafter TT, p. 25.

${ }^{16}$ Lucie Armitt, Theorising the Fantastic (London: Arnold, 1996), p. 7.

${ }^{17}$ Fred Botting, Gothic (London: Routledge, 1996), p. 3.

${ }^{18}$ It should be noted that this trek's briefness does justice neither to these theories' manifest importance and complexity, nor the amount of effort that has been invested in researching them for use here. It is presented in this way purely for the purposes of highlighting in it that which is fundamental to this discourse in as compact a form as possible. Further reading on each of these separate theories, as well as on theories of monstrosity, can be found in this thesis' bibliography.
} 
end of this journey that can now most readily assist the binding of monstrosity's nebulous structure. Over the mass of currently available criticism of the gothic, Clive Bloom states that two schools of thought preside:

The first sees such fiction as disturbing but conservative, restoring things to the status quo and dedicated to the ultimate return to normalcy. The second sees such fiction in the opposite light as disturbing in order to change, not recuperative and conservative but radical and subversive, dedicated to excess and marginality. ${ }^{19}$

The first of these two explains the experience of sublimity. The transgressive operation of an object that is perceived as sublime (as described in the terminology of Burke and Kant, as well as - to a greater, lesser, or related extent - in the discourses of the uncanny, the fantastic, and the gothic) is received by but does not overwhelm the subject. At the end of that object's action, the subject's threatened selfhood is recomposed and reinforced as normality returns and fear departs. By comparison, Bloom's second classification explicates the occurrence of monstrosity. Monstrosity begins, as it were, where sublimity ends, as that which engulfs the subject as a result of its latent terrificness. After monstrosity, a return to normality is unthinkable and a reconstitution of the self as it previously was is impossible: monstrosity indeed 'bears witness to... the aw(e)ful prospect of human integrity transgressed.' To do this, it does not have to come in a form that is evil, freakish, and non-human. In fact, remembering the obscuring duality that is indispensable in both monstrosity itself and in its uncanny contributor, monstrosity must actually be at its least effective - its least monstrous when it comes in the polar form of something evil or freakish. Its incidence will be far more powerful when it is present as something familiar but other, as something at home but not at home, as something human but non-human: 'a refraction of its mirror image: the delineation of quintessential humanity.' (EG, p. 64) Monsters attend, paradoxically, as that which they

\footnotetext{
${ }^{19}$ Clive Bloom, 'Introduction: Death's Own Backyard: The Nature of Modern Gothic and Horror Fiction,' in Gothic Horror: A Reader's Guide from Poe to King and Beyond, ed. Clive Bloom (Basingstoke: Macmillan, 1998), 1-22 (p. 13).
} 
are but that which they are not, and, by their etymologically defined prerogative to show, they change those with whom they interact. That is their function. That is, whether they like it or not, what they do.

\section{(iii) Inheritance}

In review of the terms here established around monstrosity's dialectic, their descriptive application with respect to human children must now be clear. The birth of a child is arguably the biggest event in human life. It engulfs the parental self and changes it to such an extent that what it was before can never return. The subsequent development of the child is a perpetual transgression, even abjection, of the parental self, because the child exists throughout its life as that which is of the parent and yet not the parent, that which is at home and yet not at home. Nothing delineates quintessential humanity more than the climax of humanity's reproductive process and yet nothing is more incomprehensible and ungraspable, even when it is rationalized scientifically:

Everyone starts from a single fertilized egg; from six feet of DNA. An adult, though, is made of a hundred thousand billion cells - one of those numbers so large as to be almost without meaning, ten with fourteen zeros after it - every one with its own copy of the genetic instructions, deriving, after many rounds of duplication, from that in the egg. What is more, many body cells continue to divide, with ten followed by sixteen zeros cell divisions in an average lifetime. Some cause a minute egg to grow into an enormous adult, but many more renew the body as it wears out. The body makes tens of thousands of miles of DNA an hour (men more than women as they constantly produce new sperm - a hundred million a day, containing enough DNA to put a girdle twice round about the earth - while women use up a store of eggs made before puberty). ${ }^{20}$

Statistics such as these are incredible but provable, notionally limitless but verifiably limited, monstrous but human, and they begin with the essence of the child: six feet of DNA in a single fertilized egg. Put simply:

\footnotetext{
${ }^{20}$ Steve Jones, In the Blood: God, Genes and Destiny (London: Flamingo, 1997), p. 267.
} 
Monsters are our children. They can be pushed to the farthest margins of geography and discourse, hidden away at the edges of the world and in the forbidden recesses of our mind, but they always return. And when they come back, they bring not just a fuller knowledge of our place in history and the history of knowing our place, but they bear self-knowledge, human knowledge - and a discourse all the more sacred as it arfertilizes from the Outside. These monsters ask us how we perceive the world, and how we have misrepresented what we have attempted to place. They ask us to reevaluate our cultural assumptions about race, gender, sexuality, our perception of difference, our tolerance towards its expression. They ask us why we have created them ${ }^{21}$

Although Jeffrey Jerome Cohen is writing metaphorically here, his commentary willingly submits to non-metaphoric consideration. Monsters are, figuratively but also literally, our children. We make our monsters (both physically and mentally) as we reproduce and they change us because they are part of us.

The problem is, of course, that the process of change that results from the presence of monsters can actually be deeply threatening and profoundly painful, and it is at this point that our monsters, our children, can take on a level of difference that is unacceptable and unreadable to us because of our proximity to them. Children are brought into the world with only limited selves and consequently they can easily become a voiceless commodity in the middle of the ongoing adult argument about how best to form young people into responsible adults. Children, as they fight to find themselves and their subjective personalities, are monstrous because their simultaneous selflessness but potentially uncontrollable selfhoods overwhelmingly threaten adult notions of cultural, communal, and personal self. This is reflected in the developmental methods applied to children by adults, which often result in the silencing and the maintenance of selflessness in children rather than in their individualizing development. An extreme example of this in literature can be found in Mary Shelley's Frankenstein, in which Frankenstein's offspring - 'no human father ever played so

\footnotetext{
${ }^{21}$ Jeffrey Jerome Cohen, 'Monster Culture (Seven Theses),' in Monster Theory: Reading Culture, ed. Jeffrey Jerome Cohen (Minneapolis: University of Minnesota Press, 1996), hereafter $J C$, 3-25 (p. 20).
} 
thorough-going a role in any birth ${ }^{22}$ - is rendered voiceless and communally selfless by his beyond-sublime monstrousness, no matter how verbally eloquent he evolves to be. Children, therefore, make adults' self-identification indeterminate, as they posit possibilities for new ways and new life. Where this indeterminacy threatens too nearly, children become rejected, ostracized, and made monstrous in the wicked sense of the word. To reiterate, children monsters - are not essentially wicked, but they can be made so by those who perceive them.

The fact that there exists a body of writing known as children's literature is testament to all these cultural perceptions of children being different. Children, this separate canon suggests, cannot participate immediately in literature. Instead, they need literature to be premodified to create a special literature, a unique literature, a monstrous literature, a children's literature all of their own. This literature and its remit are ironically defined, in the main, by adults, the very social group who (unwittingly) perpetuate the alienating notion of children's fundamental divergence from them. Thus, through examination of children as readers and as literary figures in English children's literature, it is possible to document the evolution of the alienation that defines them in the medium that is prescribed for them. The effect of this estrangement, the demonstration of this difference, takes many divergent forms, but its unusualness, its threat, and its monstrosity (in the terms in which monstrosity has been defined here) remain consistent. 'Monsters are our children,' writes Cohen, and it is impossible to disagree with him. To do these monsters justice, to be 'prepared... to welcome the monstrous arrivant, ${ }^{23}$ what they are perceived to be must be studied and demystified. Only then can that which they show (about) us be truly read. Only then can the real power of children's literature be truly understood.

\footnotetext{
${ }^{22}$ Marilyn Butler, 'Introduction,' in Mary Shelley, Frankenstein. 1818 Text, ed. Marilyn Butler (Oxford: Oxford University Press, 1994), ix-li (p. xliv).

${ }^{23}$ Jacques Derrida, Points... Interviews, 1974-1994, ed. Elisabeth Weber, trans. Peggy Kamuf \& others (Stanford, California: Stanford University Press, 1995), p. 386.
} 
CHAPTER TWO

THE GENESIS OF ENGLISH CHILDREN'S LITERATURE 
Specialized academic studies of children's authors and their writing remain comparatively rare. For whatever reason, only a very limited number of these authors and only a select few of their books have ever received the ostensible accolade of consistent critical recognition. It seems that frequent and specific intellectual engagement with children's literature has been and still is in some way unacceptable to the adult scholarly establishment. Studies of this medium are not the things with which to make one's mark.

Having said which, one type of critical text has long since flourished on the subject of children's literature, and that is the overview commentary. Typically, this appears in one of two forms: a chronology, such as F.J. Harvey-Darton's oft-reprinted Children's Books in England: Five Centuries of Social Life; or a compendium, such as The Oxford Companion to Children's Literature. Although presentationally different, these two approaches to the topic tend to find themselves asking the same questions of it: first, what is children's literature, and second, where, when, and with what does children's literature begin? The answer to the first of these is fluid and changes from age to age (as this thesis will tangentially demonstrate). The answer to the second is more readily resolvable and more immediately relevant here, because it defines chronologically and culturally where this study should begin. Before moving on to discussions of specific works of English children's literature, therefore, it is necessary to examine the circumstances of that literature's genesis.

The title of Darton's early twentieth-century historical treatise implies that children's books in England can be identified across (the last) half a millennium of English writing. This is broadly substantiated by Philippe Ariès' influential L'enfant et la Vie Familiale Sous L'ancien Régime (translated into English as Centuries of Childhood), ${ }^{24}$ which argues that children's literature did not and could not exist during or before the medieval period because the concept of childhood was not widely recognized before approximately the beginning of

\footnotetext{
${ }^{24}$ Philippe Ariès, Centuries of Childhood, trans. Robert Baldick (London: Jonathan Cape, 1962).
} 
the seventeenth-century. For Ariès, pre-1600 children were young adults. They were not an autonomous social group and they could not, therefore, have their own literature.

More recent scholarship, however, disputes the assumption upon which Ariès' inference is based. Writing in 1988, T.G. Ashplant and Adrian Wilson state, in relation to Centuries of Childhood, that:

The "discovery of childhood" is in fact an optical illusion, based in the main upon a naïve reading of iconographic material. People in medieval society did have "an awareness of the particular nature of childhood" - though probably an awareness different to the modern one. ${ }^{25}$

Nicholas Orme's substantial Medieval Children vindicates Ashplant and Wilson, both with respect to notions of childhood in general and children's literature in particular, by citing collections of pre-Renaissance rhymes (collated by, amongst others, the Opies and Helen Cooper) as distinct evidence of what appears to be medieval poetry - medieval literature - for children. $^{26}$ Orme's work, in conjunction with the research of those who have studied later periods of history, effectively shows that both childhood and children's literature have existed in England as discernible ideas for the better part of the last thousand years. They are not, in fact, the relatively new concepts that Ariès perceives them to be.

Within this framework, though, and in deference to Ariès, there is good reason to emphasize in this discussion the contextual significance of the seventeenth- and eighteenthcenturies. On Ariès' intellectual legacy, G.J. Barker-Benfield writes that:

Ariès's notion (from Centuries of Childhood) that the idea of childhood was "invented" from the seventeenth through the nineteenth centuries is dubious. Nonetheless, inspired by Ariès, historians have endorsed the idea of a significant change in childrearing in the eighteenth century, linking it to the spread of the ideas of Locke and, later, Rousseau, whose views were popularised by fiction...

${ }^{25}$ T.G. Ashplant \& Adrian Wilson, 'Present-Centred History and the Problem of Historical Knowledge,' The Historical Journal, 31.2 (1988), 253-74 (p. 255). This article draws on some of Wilson's earlier work, which is published as Adrian Wilson, 'The Infancy of the History of Childhood: An Appraisal of Philippe Ariès,' History and Theory, 19 (1980), 132-53.

${ }^{26}$ Nicholas Orme, Medieval Children (New Haven: Yale University Press, 2001), pp. 136-8. 
Parents' greater literacy, that primary mode for self-fashioning, was echoed by their children's, as commercial booksellers... published and priced reading materials to reach all but "the very poorest families of unskilled labourers."27

In short, as England moved into the eighteenth-century, a substantial cultural shift occurred which favoured the growth of children's literature. This movement consisted broadly of two interrelated parts: one philosophical and one practical. Philosophically, beginning in the seventeenth-century and continuing into the eighteenth-, acceptance of and engagement with notions of selfhood and identity became more prevalent with the accession of Enlightenment thinking:

In the seventeenth century there is clear iconographic and literary evidence for a new interest in the self, and for recognition of the uniqueness of the individual. This is a development common to Europe, and which apparently has its origins in two different strands of thought: the secular Renaissance ideal of the individual hero as expressed in the autobiography of Cellini or the essays of Montaigne; and religious introspection arising from the Calvinist sense of guilt and anxiety about salvation. ${ }^{28}$

This newfound tendency towards self-awareness, which revelled in the mid seventeenthcentury Cartesian doctrine of cogito, ergo sum, was heightened in the case of children's literature by the popularity of, amongst others, John Locke's Some Thoughts Concerning Education (1693) and Jean-Jacques Rousseau's Émile (1762). Practically, the rapid dissemination of this plethora of innovative ideas was made possible by the eighteenthcentury's burgeoning print culture. As John Brewer puts it, 'by the late eighteenth century, the professional author, the creator of unique works of literature, had become a recognizable type, distinguishable from both the liberal writer and the hack. ${ }^{29}$ In other words, by the late eighteenth-century, the diversity of extant writing types was sufficient to necessitate the

\footnotetext{
${ }^{27}$ G.J. Barker-Benfield, The Culture of Sensibility: Sex and Society in Eighteenth-Century Britain (Chicago: University of Chicago Press, 1992), p. 102.

${ }^{28}$ Lawrence Stone, The Family, Sex and Marriage in England 1500-1800, abr. edn (London: Penguin, 1990), hereafter $L S$, p. 153.

${ }^{29}$ John Brewer, The Pleasures of the Imagination: English Culture in the Eighteenth Century (Chicago: University of Chicago Press, 2000), p. 151.
} 
breakdown of the overarching title of author into discrete sub-categories of authorship. Writing and the population's knowledge of writing were both on the up, as printing and selfidentification boomed in mutuality. 'Literacy,' as Lawrence Stone writes, 'is... a necessary pre-condition for the growth of introspection.' (LS, p. 153) Lego, ergo sum.

In terms of post-Locke English children's literature, John Newbery was one of the first men who effectively harnessed eighteenth-century England's dual swing of interest towards print and the self. Newbery was born, in 1713, to an agricultural family, but, rather than taking over his parents' farm when he came of age, he chose instead to take his astute commercial acumen into trade in Reading. Having energetically learnt his letters as a young man, Newbery swiftly became the assistant to and eventually the partner of the printer William Carnan. When Carnan died in 1737, Newbery took over his business, and expanded it to become jointly a distributor of medicines and a publisher. From this base, he began a concerted effort to publish literature for children, notably including the probably self-penned A Little Pretty Pocket Book (1744), one of his earliest and most famous publications. Much if not most of Newbery's output was strongly influenced by the educationalist ideals of Locke.

Newbery accrued credibility and scale to his publishing venture by associating himself positively and publicly with many of his period's literary heavyweights, including Dr Johnson, Oliver Goldsmith, Tobias Smollett, and Christopher Smart. In fact, it is the commercial success that resulted from such associations that has led to the still-proliferated supposition that Newbery was England's first publisher of children's literature. As Charles Welsh (a distant relation of Newbery) points out, however, the nature of Newbery's contribution to this field is more subtle:

The first bookseller who made the issue of books, specifically intended for children, a business of any importance, [Newbery] brought before the world a number of works 
which have proved of great benefit, and of which the memory and the influence have survived to the present day. ${ }^{30}$

Note that Welsh is not saying that Newbery was the first publisher of English children's literature. What he is saying is that Newbery was the first publisher of children's literature to make it a business of any importance. Writing over a century later, Margaret Kinnell agrees exactly with this sentiment, by stating that 'John Newbery has often been credited with originating the publication of children's books; in reality, though, his role was even more important: he began the serious business of publishing for children.'31 'Newbery's significance,' according to Kinnell, 'lay in developing the children's side of his publishing business to such an extent that this class of book could be seen as worthy of the kind of artistic and financial investment reserved for adult books.' $(M K, \mathrm{p} .35)$

Thus, it is clear from the evidence of the success of Newbery and those like him that, by the middle of the eighteenth-century, children's literature in England had developed into not only an identifiable artistic notion but also a viable commercial prospect. English children's literature may not have been born in the seventeenth- and eighteenth-centuries, in the way that Ariès perceives it to have been, but it certainly evolved in them into a medium of sufficient significance to warrant intensive study. Taking the mid eighteenth-century as the starting date for this thesis' primary material, therefore, the final issue to be considered at this stage is the ostensible purpose of this formative writing for children. That purpose may be thought of, in short, as a socio-literary argument between sentiment (sense) and sensibility.

Roy Porter, citing Locke as one of the instigators of the Enlightenment's social revolution of English perceptions of children and childhood, writes that 'Locke did not idealize infant

\footnotetext{
${ }^{30}$ Charles Welsh, A Bookseller of the Last Century: Being Some Account of the Life of John Newbery, and of the Books he Published, with a Notice of the later Newberys (London: [printed for] Griffith, et al., 1885), p. vii.

${ }^{31}$ Margaret Kinnell, 'Publishing for Children 1700-1780,' in Children's Literature: An Illustrated History, ed. Peter Hunt (Oxford: Oxford University Press, 1995), 26-45, hereafter $M K$ (p. 34).
} 
innocence - sentimentality came later, and child worship began only with Romanticism., 32 Porter is surely correct but his terminology raises a problem. The cognates of the noun sentiment, particularly when viewed against the malleable context of the eighteenth-century's sentimental literature, can cause a lot of difficulties. Above, Porter uses sentimentality as a term to describe a pre-cursor condition to Romantic child worship. This implies that sentimentality should be linked with strong, perhaps even obsessive, emotions, which in this instance lead to the idealization of infant innocence. Understandings of sentiment, though, do not always reconcile with this:

In all forms of sentimental literature, there is an assumption that life and literature are directly linked, not through any notion of a mimetic depiction of reality but through the belief that the literary experience can intimately affect the living one...

A "sentiment" is a moral reflection, a rational opinion usually about the rights and wrongs of human conduct; the early eighteenth-century novel of sentiment is characterized by such generalized reflections. But a "sentiment" is also a thought, often an elevated one, influenced by emotion, a combining of heart with head or an emotional impulse leading to an opinion or a principle. ${ }^{33}$

The fact that there are different forms of sentimental literature is important, because these alternative renderings of sentiment, taken from Janet Todd's Sensibility: An Introduction, certainly do not construct it as a term which links in with Porter's use of sentimentality. For Todd, eighteenth-century sentiment joins life and literature within a moral and/or emotionally elevated (though not neurotic) reflective framework. This is certainly not the language of emotional hyperbole, with which sentimentality is most frequently linked. This is something else, something balanced, something which sounds - in fact - really quite sensible.

Now consider this account of sentiment alongside Todd's contrasting description of sensibility:

\footnotetext{
${ }^{32}$ Roy Porter, Enlightenment: Britain and the Creation of the Modern World (London: Penguin Books, 2000), p. 340.

${ }^{33}$ Janet Todd, Sensibility: An Introduction (London: Methuen \& Co., 1986), hereafter JT, pp. 4-7.
} 
Little used before the mid-eighteenth century, although Addison among others employed it to suggest delicate emotional and physical susceptibility, it came to denote the faculty of feeling, the capacity for extremely refined emotion and a quickness to display compassion for suffering...

"Sensibility," an innate sensitiveness or susceptibility revealing itself in a variety of spontaneous activities such as crying, swooning and kneeling, is defined 1797 by the Encyclopedia Britannica ( $3^{\text {rd }} \mathrm{edn}$ ) as "a nice and delicate perception of pleasure or pain, beauty or deformity," which, as far as it is natural, "seems to depend upon the organization of the nervous system."

$$
(J T, \text { p. 7) }
$$

Particularly in the latter half of this explanation of sensibility, we find material which seems coterminous with definitions of sentimentality. Heightened feelings, coupled with excessive nicety and delicacy, which lead to crying and swooning, i.e., physical manifestations of emotional melodrama, all sound like the hallmarks of contemporary sentimentality. Thus, if Todd's separate account of sentiment is correct, ${ }^{34}$ then - at least as far as the eighteenthcentury is concerned - sensibility and sentimentality seem to share semantics whereas sensibility and sentiment do not. The noun sentiment certainly has different and more positive connotations than those which are associated with the adjective sentimental and the noun sentimentality. One can have a noble and sturdy sentiment, as it were, but one cannot be nobly and sturdily sentimental. So, the literature of sentiment, as defined by Todd, has no interest in idealizing infant innocence, whereas the literature of sentimentality, as used by Porter, may well have. Also, if sentiment is truly a literary mode which can demonstrate the merits of morality and the value of literature as a means by which to establish it, then what

\footnotetext{
${ }^{34}$ It is important to recognize that there are views other than Todd's on this subject, and Markman Ellis is one who proves wary of wholeheartedly subscribing to her approach. Writing in 1996, Ellis states that: "Many recent critics, taking a "history of ideas" approach, have located the origin of literary sentimentalism in the writings of the moral philosophers of the early eighteenth century, constructing a history of sentimentalism - which might be called the "Enlightenment account" - that traces the progressive refinement of ideas about virtue and society, benevolence and taste through the philosophical writings of the period.' (Markman Ellis, The Politics of Sensibility: Race, Gender and Commerce in the Sentimental Novel (Cambridge: Cambridge University Press, 1996), hereafter MA, p. 9) In particular, Ellis accuses some writers - Barker-Benfield, for example - of overstating the case that sensibility was a phenomenon of middle-class gender evolution, which heightened the emotions of women on the one hand whilst feminizing men on the other. (MA, p. 27) However, whilst introducing some interesting variations upon the theme, neither Ellis, Barker-Benfield, nor Jerome McGann (The Poetics of Sensibility: A Revolution in Literary Style) - to name but a few - contradict the divergent descriptions of sentiment and sensibility that are used by Todd.
} 
should be expected from a sentiment (as opposed to a sentimental) text is an educationary, even didactic, approach to its contents.

This latter trait, of tending towards the often overt propagation of often equally overt moral maxims, is one of the foremost characteristics of eighteenth- and early nineteenthcentury English children's literature. It is certainly not the mode's only characteristic, but it is nevertheless, broadly speaking, where popular English children's literature begins. This sentiment (or, as one might contextually rename it, sense) approach argues, in the wake of Locke and Rousseau, that the lives of children should be imbued as soon as possible with an unambiguous moral context, regardless of the debatable state of theological or social innocence into which they are born. By comparison, advocates of the 1740-1770 'cult of sensibility' (JT, p. 3) would be more likely to espouse the emotionally driven beginnings of Romantic child worship, in which all youthful foibles would be justified by children's ongoing state of childish innocence and excellence. Between these two warring factions, children are caught and objectified. They are made into pawns to be manipulated in adult social games. They emblematize that which adults dislike about each other. They unnerve, disquiet, and speak volumes about the society that writes them and writes for them. In children's literature, they become, quite literally, little monsters. 
CHAPTER THREE

THOMAS DAY: SENSE VERSUS SENSIBILITY 
Thomas Day, one of late eighteenth-century England's best-selling writers of children's literature, is more-or-less disregarded by modern criticism. On the rare occasions when he is mentioned, he usually suffers a quick dismissal as a deeply eccentric Rousseau obsessive. This viewpoint is understandable when considered in the context of Day's unconventional life story, but it is also an oversimplification. It is certainly true that Day was enthusiastic about Rousseau's Émile, and that in some of his apparent behaviour towards that book there is plenty of evidence to convict him on multiple charges of outrageous eccentricity, but these are reductions which do not alone do him justice. Against the backdrop of eighteenthcentury children's literature, Day's writing epitomizes the dialogue between sense (sentiment) and sensibility which more generally characterizes the children's literature of the period. Against the backdrop of monstrosity and its discourse of the different, both Day's biography and his authorship provide excellent examples of the effects of social deviance at work. In short, Day's current position in the critical canon underestimates him and is in need here of reconfiguration. This will be done by evaluating some of the more piquant aspects of his famously peculiar biography, before looking at the ways in which these (wrongly) devalue appreciation of his most famous children's book, Sandford and Merton.

\section{(i) An English Disciple of Rousseau?}

Thomas Day was born on June $22^{\text {nd }} 1748$ and was brought up in London. His father - a wealthy man, who held a number of substantial country properties - died barely thirteen months later, leaving his son a fortune of $£ 1000$ per annum. Day junior was educated at Stoke Newington and at the Charterhouse School in London. He was admitted as a gentleman commoner into Corpus Christi, Oxford, in 1764. 
Also attending the College at that time, having entered it in 1761, was Richard Lovell

Edgeworth (later the father of Maria Edgeworth), with whom Day swiftly became a firm friend: ${ }^{35}$

Their long conversations dealt with literature and metaphysics, particularly the latter. And in their admiration for Rousseau's educational system as given in Emile there was much subject for discussion. Edgeworth had decided to rear his child as Emile had been reared; Day wished to do all things as Emile had - to travel, to marry, to retire to a country retreat where he might give a natural education to his own hardy brood of Emiles.

$$
(G G, \text { p. 37) }
$$

Despite such evidence of Day and Edgeworth's fervent conversations about Émile, we have no record of the date upon which Day first encountered Rousseau's text. We do know that Day was approaching his fourteenth birthday when Émile and Du Contrat Social were initially published in their native French (1762). We also know, according to George Warren Gignilliat's biography of Day, that he was an established Émile addict by the time he reached eighteen. By that time, 'what Robinson Crusoe was to Émile $e^{36}-E^{\prime} m i l e$ was to Thomas Day. $^{, 37}$

The essence of Émile's approach to youth instruction is that children are born as God's innocents $^{38}$ into nature ${ }^{39}$ and are subsequently corrupted by poor teaching and society. ${ }^{40}$ The

\footnotetext{
${ }^{35}$ George Warren Gignilliat, The Author of Sandford and Merton: A Life of Mr. Thomas Day, Esq. (New York: Columbia University Press, 1932), hereafter $G G$, p. 28.

36 'Since we must have books, there is one book which, to my thinking, supplies the best treatise on an education according to nature. This is the first book Emile will read; for a long time it will form his whole library, and it will always retain an honoured place... What is this wonderful book? Is it Aristotle? Pliny? Buffon? No; it is Robinson Crusoe... Robinson Crusoe on his island, deprived of the help of his fellow-men, without the means of carrying on the various arts, yet finding food, preserving his life, and procuring a certain amount of comfort; this is the thing to interest people of all ages, and it can be made attractive to children in all sorts of ways.' (Jean-Jacques Rousseau, Émile, trans. Barbara Foxley (London: J.M. Dent, 1993), hereafter JR, p. 176)

${ }^{37}$ Muriel Jaeger, Experimental Lives: From Cato to George Sand (London: G. Bell \& Sons, 1932), p. 142.

38 'God makes all things good; man meddles with them and they become evil.' $(J R$, p. 5) 'Let us lay it down as an incontrovertible rule that the first impulses of nature are always right; there is no original $\sin$ in the human heart, the how and why of the entrance of every vice can be traced... Cease to blame others for your own faults; children are corrupted less by what they see than by your own teaching.' ( $J R$, pp. 66-70)
} 
only way of breaking this otherwise inevitable chain of events is to provide a child, in isolation, with a carefully selected tutor who will act throughout that child's young life as its sole companion and confidante. Edgeworth and Day - both of whom held a strong educationalist desire to contribute to humanity's improvement - fell voraciously upon these principles and were quick to put them to the test. Edgeworth attempted to bring up his first son, also a Richard, according to Émile's maxims, and he met with a degree of success:

I dressed my son without stockings, with his arms bare... I succeeded in making him remarkably hardy: I also succeeded in making him fearless of danger, and, what is more difficult, capable of bearing privation of every sort. He had all the virtues of a child bred in the hut of a savage, and all the knowledge of things, which could well be acquired at an early age by a boy bred in civilized society... He was bold, free, fearless, generous; he had a ready and keen use of all his senses, and of his judgment. ${ }^{4 l}$

However, the overall result of the trial was far from satisfactory:

But he was not disposed to obey: his exertions generally arose from his own will; and, though he was what is commonly called good-tempered and good-natured, though he generally pleased by his looks, demeanour, and conversation, he had too little deference for others, and he shewed an invincible dislike to control. With me, he was always what I wished; with others, he was never any thing but what he wished to be himself.

$$
\text { (RE, p. 179) }
$$

The conclusion of Day's experiments was equally disappointing. Without a child of his own upon whom to impose his interpretation of Émile, Day instead analogized himself with the character of Émile (the child in Rousseau's text to whom its various educational practices are

\footnotetext{
39 'We are born sensitive and from our birth onwards we are affected in various ways by our environment. As soon as we become conscious of our sensations we tend to seek or shun the things that cause them, at first because they are pleasant or unpleasant, then because they suit us or not, and at last because or judgments formed by means of the ideas of happiness and goodness which reason gives us. These tendencies gain strength and permanence with the growth of reason, but hindered by our habits they are more or less warped by our prejudices. Before this change they are what I call Nature within us.' $(J R$, p. 7$)$

${ }^{40}$ 'The natural man lives for himself; he is the unit, the whole, dependent only on himself and on his like. The citizen is but the numerator of a fraction, whose value depends on its denominator; his value depends upon the whole, that is, on the community. Good social institutions are those best fitted to make a man unnatural, to exchange his independence for dependence, to merge the unit in the group, so that he no longer regards himself as one, but as a part of the whole, and is only conscious of the common life.' $(J R$, p. 8)

${ }^{41}$ Richard Lovell Edgeworth \& Maria Edgeworth, Memoirs of Richard Lovell Edgeworth, Esq., 2 vols (London: [printed for] R. Hunter, 1820), I, hereafter RE, pp. 178-9.
} 
applied) and set out to find himself a Sophie (the young lady who is selected by Émile's tutor to become Émile's eventual wife). To this end, Day purchased two orphan girls (aged eleven and twelve) from a foundling hospital with the intention of grooming them so that one could eventually become his Sophie. He could not, of course, marry them both, but having two subjects rather than one to work on increased the chances of his research resulting in a successful outcome. One of the girls would hopefully develop in an agreeable way, and the other one could then be discarded and provided for. Unfortunately for Day, despite his assiduous pursuit of this path, he was eventually forced to admit defeat when it became obvious to him (and everybody else) that neither of his two protégées was Sophie material. The experiment was abandoned, put down to experience, and one of the girls went on to marry Day's friend, John Bicknell.

The image of Day conjured up by this last and most frequently emphasized episode from his biography is undeniably that of a man who was hugely eccentric, and it adds fuel to the fire of those who wish to write him off as one who became simply too fanatical in his discipleship to Rousseau. Indeed, the noun discipleship could hardly be a more apt descriptor when it is considered that Day once reported Émile to be a book second only in his mind to the Bible:

Were all the books in the world to be destroyed, except scientific books (which I should except, not to affront to you) the second book I should wish to save, after the Bible, would be Rousseau's Emilius. It is indeed a most extraordinary work - the more I read, the more I admire - Rousseau alone, with a perspicuity more than mortal, has been able at once to look through the human heart, and discover the secret sources and combinations of the passions. Every page is big with important truth... "Excellent Rousseau!" first of humankind! ${ }^{42}$

Understandably, Day's well-documented obsessive views on Émile, coupled with the diverse ways in which they were made manifest in his behaviour, have muddied the majority of what

\footnotetext{
${ }^{42}$ Thomas Day, in $R E$, p. 226.
} 
little criticism exists on his writing. Even beyond this fixation, most biographies of Day represent him as a man who was an antisocial philanthropist, who advocated indigent simplicity whilst living off a substantial annual income, and who took a calculatedly pragmatic view of marriage and relationships whilst frequently and not very pragmatically falling in love. His life, in short, seems to have been characterized by a series of paradoxes, inconsistencies, and mania. It is all too easy to dismiss him as a lunatic.

This dismissal, in fact, is made all the easier by its essential accuracy: a lunatic - in the sense of being a member of the Lunar Society of Birmingham - was quite literally what Day was. It is not a little ironic that Jenny Uglow, in her book which details the history and actions of the Society, is one of the most recent critics to suggest that there is more to Day than his apparent lunatic madness suggests:

'[Day] became touchingly devoted to [William] Small, who sensibly argued him out of studying medicine, persuading him he might not be the most effective of doctors. Instead Day poured his idealism into education, anti-slavery campaigns and political causes, and into writing his famous children's book Sandford and Merton. For all his oddities, he become, in many ways, a remarkable figure and the older Lunar men rightly took him seriously. ${ }^{43}$

Clearly, Uglow is not trying to say that Day was not a peculiar man, because to do so would fly in the face of irrefutable evidence that he was. She is, however, saying that there was a degree of substance beyond his too-well-documented strangeness that makes him worthy of more considered study. In this context, Day is perhaps best summarized in the connotations of a phrase taken from the first epistle in Maria Edgeworth's Letters for Literary Ladies (which was based on a letter written by Day to Maria's father Richard ${ }^{44}$ ): 'prodigies are

\footnotetext{
${ }^{43}$ Jenny Uglow, The Lunar Men: The Friends Who Made the Future 1730-1810 (London: Faber \& Faber, 2002), p. 184.

44 '[Day] was horrified that his friend was encouraging the young Maria to read philosophy and politics. His outrage was even greater when Richard Lovell Edgeworth told him he had also begun to encourage his daughter to write. Edgeworth had, in fact, asked his daughter to begin a translation of Madame de Genlis' Adèle et Théodore: ou, lettres sur l'education. Adelaide and Theodore was, in fact, never published as another translation made it to the shelves first. This delighted Day... He
} 
scarcely less offensive to my taste than monsters.' ( $M E$, p. 1) Day, undoubtedly, was something of a prodigy. He is now regarded, because of his apparently excessive interpretations of Rousseau, to have been something of a monster as well. This last though, to reiterate, is an oversimplification, albeit a comprehensible one. Day may well have been deviant, different, and strongly influenced by Émile, but solely a disciple of Rousseau - as we shall see - he categorically was not.

\section{(ii) Sandford and Merton: Sense, Sensibility, and Solitude}

In 1778 , Day finally managed to acquire a wife - Esther Milnes - and they lived variously in Essex and Surrey throughout their eleven years of wedded life (until Day was killed in a horse-riding accident in September 1789). It was during this period that Day set about the composition of his most famous book, The History of Sandford and Merton, ${ }^{45}$ which is immediately - on its title page - identified as 'A Work Intended for the Use of Children., 46 In Sandford and Merton's preface, Day writes that 'all, who have been conversant in the education of very young children, have complained of the total want of proper books to be put into their hands, while they are taught the elements of reading.' (TD, I, p. iii) Since the purpose of Day's book is to address this apparent want, this comment is perhaps unsurprising. However, implicit self-congratulation aside, Day proposes to manage this

\footnotetext{
wrote at once to Richard Lovell Edgeworth, congratulating him on having saved his daughter from the despicable world of female authorship. Maria based the first two letters in Letters for Literary Ladies on this exchange.' (Claire Connolly, 'Introduction,' in Maria Edgeworth, Letters for Literary Ladies, ed. Claire Connolly (London: J.M. Dent, 1993), hereafter $M E$, xvi-xxvi (p. xix))

${ }^{45}$ Sandford and Merton presents something of bibliographical problem. It was first published in three anonymous volumes (in 1783, 1786, 1790, respectively), but was subsequently edited, revised, and abridged into innumerable divergent editions. Although a number of these different versions have been examined in the course of researching this thesis (and are listed in the bibliography), the citations to Sandford and Merton that are made in it are to the book's earliest complete edition, i.e., the three volume collection of 1790. An intriguing aside to the naming of Day's book is the fact that he lived for significant stages of his life in both Oxford and Surrey, during which times he would have been close to Sandford-on-Thames and Merton, respectively. No evidence has been found in this project's research which suggests that Day had links with either place, but, contextually, it seems hard to countenance that their presence in Sandford and Merton's title is nothing more than a coincidence.

${ }^{46}$ Thomas Day, The History of Sandford and Merton, $5^{\text {th }}$ edn, 3 vols (London: [printed for] John Stockdale, 1790), hereafter $T D$, I, p. i.
} 
important enterprise by drawing together passages from what he considers to be essential authors and texts - named examples of which include Xenophon, Plutarch, and Robinson Crusoe - within a narrative framework that is suitable for young minds:

I have only to add, that I hope nobody will consider this work as a treatise on education. I have unavoidably expressed some ideas upon this subject, and introduced a conversation not one word of which any child will understand; but all the rest of the book is intended to form and interest the minds of children; it is to them that I have written; it is from their applause alone I shall estimate my success; and if they are uninterested in the work, the praises of an hundred reviewers will not console me for my failure.

$$
\text { (TD, I, pp. viii-ix) }
$$

What is imperative here is the vehemence of Day's insistence that he is writing for children and not adults: the alienated peculiar adult is writing for what he claims to be an underattended - and hence, to a degree, marginalized and alienated - social group. This constitutes a manifold refutation of Émile's educationalist methodologies. The very fact that Day is writing a book, which he claims repeatedly is a work which is to be read by children, differentiates it clearly from Émile, because Jean-Jacques (Émile's tutor) would neither read to nor let his youthful charge read anything other than Robinson Crusoe. Texts by two of Ancient Greece's most famous philosophers could never have been on Jean-Jacques' literary menu for Émile, because such a diversity of potentially thought-inducing material would have had catastrophic effects upon the young Émile's upbringing. Indeed, the very act of writing a book for children could not have been on Émile's agenda because the act represents a tacit promotion of child reading. It is notable also that Day's narrator takes the fact that one of Sandford and Merton's youthful protagonists cannot read by the age of six to be a point of censure, (TD, I, p. 14) whereas one presumes that the child of Émile who could read by that age would be regarded as an utter failure. Émile's discourse is essentially directed towards the parents or guardians of children: 'tender, anxious mother, I appeal to you.' ( $J R$, p. 5) Sandford and Merton is intended for children themselves. 
Thus, whatever the nature of Day's indebtedness to Emile (the general existence of which, from Day's biography, is indisputable), it is vital that Sandford and Merton is not mistakenly read as a straight homage to or reinterpretation of it. Gignilliat's study, for all the helpfulness of its biography, illustrates many of the problems that result from such approaches:

The philosophy [of Sandford and Merton] was Rousseauistic in origin, but Day, the follower, was prone to emphasize some details out of all proportion. Rousseau advocated as a part of the simple life, simple clothes; Day was a fanatic on the subject, and... made the climax to Tommy's conversion the scene where he raked the powder from his hair and clipped the buckles from his shoes. Educate a child hardily that he may be prepared for any changes in fortune, says Rousseau; give a child a hardy education, says Day, that he may take care of himself when he is cast upon a desert island. A hardy education brings virtues which conduce to a happy life, says Rousseau; a hardy education brings virtues, and virtues are always rewarded, says Day.

$(G G$, p. 293)

This reading is reductive because it assumes that the young Émile-obsessed Day is the author of the relatively mature Sandford and Merton. It exaggerates the links between the two and in doing so misrepresents the purpose of Day's text. Gerald Newman gets closer to the heart of the matter when he writes that, in Sandford and Merton, 'Day divides all society into two groups, persons of fashion and everyone else. ${ }^{, 47}$ This is a much more interesting proposition because it gestures towards the essence of Sandford and Merton's central social critique. On the one hand, Newman says, are persons of fashion and on the other are persons who are not. Or, to put it another way (and with all due apologies to Jane Austen), on the one hand are persons of sensibility and on the other are persons of sense.

These two polarities - by way of example of the practice in children's literature of using young people as pawns in adult cultural arguments - are represented in Sandford and Merton by two little boys. Tommy Merton, in the sensibility corner, is the son of a wealthy

\footnotetext{
47 Gerald Newman, The Rise of English Nationalism: A Cultural History, 1740-1830 (London: Weidenfeld \& Nicolson, 1987), p. 102.
} 
Jamaican-estate-owning English merchant. Harry Sandford, in the sense corner, is the son of a poor farmer. Tommy and Harry are brought together by Mr Barlow, the parish clergyman and Harry's tutor, who - at the request of Tommy's father, Mr Merton - agrees to take on Tommy as a second pupil. Mr Barlow's function in the friendship which develops between the boys is twofold. First, he provides a balanced intermediary between them. Second, he acts as an indicator by which they can measure the acceptability of their behaviour towards one another and towards other people. In the second of these capacities, Mr Barlow seems to be biased consistently in Harry's favour, because he condones the simplicity and courteousness of the Sandfords above the gentlemanly excesses and falsity of the society kept by the Mertons. This means that Tommy is the child who is most overtly educated in Sandford and Merton and who appears to be the subject of most of its social criticism. However, it is not Tommy himself who is under attack, but rather the value system that makes him the sickly, weedy, and plaintive individual that he is at the story's beginning. $\mathrm{Mr}$ Barlow facilitates Tommy's dialogue with Harry in order to effect the improvement of Tommy's character. He permits exchange where otherwise, one presumes, there would merely be schism.

The narrative structure within which Tommy's improvement occurs is, in fact, strikingly simple. Tommy, under the care of Mr Barlow and with the assistance of Harry, becomes a more robust, healthy, and happy child, through a combination of instruction and experience. The instruction element of Tommy's tuition takes the form either of words of guidance (usually from Mr Barlow) or of didactic stories which are interpolated into Day's narrative. Later in the text, when Tommy returns home to his parents' house for a series a social functions, he loses all of his newfound benefits amid the ignorance, folly, and caprice of his sensibility-ridden social peers. It is only when Tommy has occasion to realize the true value 
of his friendship with Harry that he is made aware of the errors of his regression. Tommy is then reinstated on the path of Barlowian sense and the book resolves accordingly.

Mr Barlow's educative methodology relies for success upon its learners' perceptions of causality and the educator's explanation of causality's operation. ${ }^{48}$ When Tommy first moves in with Mr Barlow, the clergyman and Harry undertake a morning of energetic work in the garden in which Tommy refuses to participate because he is 'a gentleman, and [does not] chuse to slave like a ploughboy.' (TD, I, p. 54) The result of this is that, when $\mathrm{Mr}$ Barlow and Harry take a break from their labours in order to eat some cherries, Tommy is not offered any. He responds to this treatment by bursting into tears:

What is the matter, said Mr. Barlow very coolly to [Tommy]? Tommy looked upon him very sulkily, but returned no answer. Oh! sir, if you don't chuse to give me an answer, you may be silent; nobody is obliged to speak here. Tommy became still more disconcerted at this, and, being unable to conceal his anger, ran out of the summerhouse, and wandered very disconsolately about the garden; equally surprised and vexed to find that he was now in a place where nobody felt any concern whether he was pleased or the contrary.

$$
(T D, \text { I, p. 55) }
$$

In summary, Tommy's behaviour renders him mute. He tries his standard response when faced with disappointment, i.e., crying the tears of over-emotional sensibility, but he is rebuffed. He has no discourse which he can use to resolve this situation and he is utterly shut out from the society of Mr Barlow and Harry. This process continues until dinner time, when Tommy expects to be permitted back into communion with the others. Again, though, he meets with Mr Barlow's closed door policy:

No, sir, as you are too much a gentleman to work, we, who are not so, do not chuse to work for the idle. Upon this, Tommy retired into a corner, crying as if his heart would break, but more from grief than passion, as he began to perceive that nobody minded his ill temper.

$$
(T D, \text { I, p. 60) }
$$

\footnotetext{
${ }^{48}$ This provides yet another contrast with Émile, in which the process of reasoning with Émile is shunned in favour of his complete and unquestioning submission to the teachings of Jean-Jacques.
} 
On this second occasion, the reason for Tommy's ostracization is made absolutely clear to him: he has not worked and he will not therefore be rewarded with work's earned fruits. Once more, he is left without a voice and is reduced to tears, but his crying - which he has used hitherto to command what he wants - is again reiterated to be worthless in this new context of Mr Barlow's house. Tommy is backed into a literal and figurative corner from which he cannot on his own escape. Fortunately for him, Harry subsequently offers to share some of his dinner with Tommy, and Tommy, sensible of this gesture's generosity, is allowed out of his corner and back in to the narrative as it is recorded by the narrator that he thanks Harry for his kindness.

It is no accident that, after this occasion has been completed, Tommy's reported speech is not reintroduced into the text until a number of narrative weeks have passed. His voice - his viewpoint and his vehicle of self - is kept out of Sandford and Merton, because it has been deemed in some way unacceptable to the Barlowian context. In order for Tommy to truly reinvigorate himself, in order for his character to truly stake a claim on the evolution of Sandford and Merton's narrative, he needs to make a clear signal of his intention to move away from his sensibility ridden past. He achieves this through his dealing with his inability to read. The initial step of this process is for him to publicly admit - to Mr Barlow and Harry - his inadequacy: '[Tommy], looking a little ashamed, said, he had never learned to read.' (TD, I, pp. 61-2) Note that it is still the narrator's voice and not Tommy's that records this confession, but this is nonetheless a definite and positive gesture towards truthfulness in the little boy's character, particularly since he realizes that his inability to read is somewhat shameful. However, it is only later, when Tommy wants to indulge in a book but finds noone available to read it to him, that his own voice is reintroduced into the text as he mulls over potential solutions to the problem presented to him: 
Now if I could but read like Harry Sandford, I should not need to ask any body to do it for me, and then I could divert myself: and why... may not I do what another has done? To be sure, little Harry is very clever, but he could not have read if he had not been taught; and if I am taught, I dare say, I shall learn to read as well as he. Well, as soon as ever he comes home, I am determined to ask him about it.

$(T D, \mathrm{I}, \mathrm{p} .73)$

The detail and the movement in this short speech are nothing short of staggering: in three sentences, they achieve a renaissance of Tommy. First, he compares himself - in a constructive and unjealous way - to Harry, and acknowledges to himself that Harry has a useful ability that he, Tommy, has not. If Harry can acquire special skills, rationalizes Tommy, then so too can he. Indeed, he shall be motivated to do so, because becoming literate will permit him to read to himself and therefore avoid being beholden to other people for his pleasure. Finally, Tommy realizes that by asking Harry - not commanding or cajoling Harry, but by asking Harry - for assistance, he is likely to be granted constructive help with his difficulty. These are astounding progressions for the lad and they lead to him undergoing two months of hard reading lessons with Harry, and, at the end of it all, he can read. (TD, I, p. 74) He sees the chain of logic between work and reward, and is permitted to enjoy the fruits of his labour by surprising Mr Barlow with a demonstration of his new proficiency. (TD, I, pp. 75-84) Admittedly, Tommy lets himself down a little by a display of vanity at the end of his reading, (TD, I, p. 85) but he has nevertheless - in a relatively short space of narrative time - evolved greatly. He has a new talent and, more importantly, he has his voice back. He is included again and he is acceptable again. 'In this manner did Mr. Barlow begin the education of Tommy Merton.' (TD, I, pp. 85-6)

Sequences such as these are typical of the method by which Mr Barlow shapes Tommy's learning curve, which nearly always revolves around the redefinition of Tommy's notion of himself as a gentleman. This is logical because, to reiterate, it is not Tommy who is under attack in Sandford and Merton but the (nominally gentlemanly) value system which has 
previously moulded him. Mr Barlow's denigration of the gentry and their sensibilities does not, when it comes, pull any punches:

So, now I see what constitutes a gentleman - A gentleman is one, that, when he has abundance of every thing, keeps it all to himself; beats poor people if they don't serve him for nothing; and, when they have done him the greatest favour, in spite of his insolence, never feels any gratitude, or does them any good in return.

$$
\text { (TD, I, p. 101) }
$$

The overall effect of this approach, as has already been seen, is forcibly to break Tommy apart from the gentlemanly niceties which he increasingly regards as disgusting. This occurs as part of a two stage process. First, when Tommy displays gentlemanly pretensions, $\mathrm{Mr}$ Barlow's vilification of them alienates Tommy from the new community of his ostensibly more worthy master and peer. Second, as Tommy realizes that he actually prefers his new community to his old one, he realizes that it is not him that is being alienated but the incorrect lifestyle (in terms of $\mathrm{Mr}$ Barlow) which his character can all-too-readily emblematize. Tommy - as a single, self-contained unit - is opened to the possibility of philosophical realignment by Mr Barlow's direct invasion into the structures of his life. The isolation, the alienation, the monstrosity, which this brings to Tommy is - the narrative implies - self-inflicted, and arises as a result of Tommy's tendency to pretend to the position of gentleman in a context in which such paper titles have no worth. Tommy's improvement can only be facilitated by the combination of his awareness of this monstrosity, his ability to identify with what it is associated, and his desire to get it out of his system. This, implicitly, is designed to have a mimetic effect upon Sandford and Merton's projected child reader: as Tommy is made monstrous and his sadness is experienced, so too the reader is meant to identify with him and share his wish to leave behind that which makes him so patently unacceptable. 
Sandford and Merton, then, operates through what Judith Plotz terms its counterbalancing of 'social exposure with subnarratives of isolation." 49 This phrase is particularly helpful, but it must be qualified with the caveat that isolation in Sandford and Merton - as we have clearly seen - is not restricted solely to the book's subnarratives. The defence for Plotz's terminology is that the specific narratives that she refers to - beyond the overt narrative of Tommy's development through his alternate isolation and reintegration are the interjected separate narratives which Day inserts into his history's framework. These subnarratives, like Tommy's main narrative, are certainly dominated by the theme of isolation, and, as such, they restate and reinforce the overarching story to which they contribute. One of these tales is called 'Extracts from a Narrative of the extraordinary Adventures of four Russian Sailors, who were cast away on the desert Island of East Spitsbergen;' (TD, I, pp. 137) it documents how four men deal with the adversity of their difficult circumstances on an isolating island. In another story, a corpulent gentleman is cured of his gout by a programme of abstinence, exercise, and lack of servants to wait upon him: he is isolated from the laziness and wantonness of his former lifestyle and is subsequently made well. (TD, II, pp. 25-49) In another, a group of people living near to the Alps are trapped in a stable by an avalanche: through their frugality and their good management of the resources that are enclosed with them, they manage to survive their imposed isolation. (TD, II, pp. 85-93) Even in Greenland, one of the world's coldest and most isolated countries, the populace - the reader learns - can efficiently maintain a subsistence living. (TD, II, pp. 171-86)

Thus, isolation is a highly significant educative tool within Sandford and Merton because it reveals so many important traits and skills within the characters to whom it gets applied. It is not, however, the be-all-and-end-all, and it is certainly not a condition towards which $\mathrm{Mr}$

\footnotetext{
${ }^{49}$ Judith Plotz, Romanticism and the Vocation of Childhood (New York: Palgrave, 2001), p. 66.
} 
Barlow ultimately wishes to push Tommy. Although Mr Barlow does not approve of society, in the gentlemanly sense of the term, he nevertheless appreciates sociability, and wishes to demonstrate the power of discourse. It is this dialogic nature, in fact, which reveals the height of Tommy's alienation when he shuts himself off from the community of $\mathrm{Mr}$ Barlow and Harry, because, in a book which is called The History of Sandford and Merton, it is difficult to exist as one of the title's named characters without participating in the title's conjunctive mutuality. Sandford and Merton - a community, a togetherness, a mutuality, a reciprocity, a conjunction - is the ideal towards which Day's history moves. Diversions from it serve to heighten that ideal and to emphasize its power when it is eventually restated.

With this inherently mutual nature in mind, then, it is important to realize that Tommy is not the only character who suffers social ostracization in Sandford and Merton. Although Tommy is the child at the centre of the book, because it is he who - in the book's terms - is in need of education, it is nevertheless imperative to the book's dialogism that mutuality should exist between its namesake protagonists. It is necessary, therefore, that Harry should also participate in and experience Tommy's monstrosity, and the occasion for this occurs at the book's midpoint, at the zenith of Tommy's initial progress. At this time, 'Tommy was by appointment to go home and spend some time with his parents,' (TD, II, p. 222) and, at Tommy's father's request, Harry is scheduled to accompany him. Harry, note, 'had no great inclination for the expedition; however, his temper was too easy and obliging to raise any objections, and the real affection he now entertained for Master Merton, rendered him less averse than he would otherwise have been.' (TD, II, p. 223) Harry's lack of enthusiasm for the occasion is born from his hitherto negative experience of polite society, but, because Tommy is his friend, he determines to put aside his reservations and go (which implicitly shows him in a courageous and virtuous light). Unfortunately, both for Harry and Mr Barlow - the latter of whom had seen this coming - Tommy's return to the society of his social 
equals does nothing other than put him back in the way of the caprice and sensibility that he has been at such pains to set aside. Even worse, Tommy's ready assimilation of this caprice and sensibility endears him to the genteel company at the Mertons' and distances him from Harry, who cannot understand the compromises of character that Tommy is prepared to go through in order to ingratiate himself with the assembled party. Now it is Harry who is in the position of the monstrous social outcast. He has no fashion. He has no money. He has neither rhetorical nor physiological elegance. He has, in short, nothing to recommend him to high society, and so now it is he who is backed into a corner.

Of course, Harry's lack of upper class social graces is actually to his credit within the narrative of Sandford and Merton, and so the alienation which he experiences is subtly different to that which has been previously experienced by Tommy. Harry acts as a beacon of Barlowian sense in the midst of Mertonian sensibility, and is unappreciated by all except Miss Simmons, who is the only other young person present at the Mertons' who has a set of true manners equal to Harry's own. It is this difference in degrees of understanding of manners (and their attendant faculties) that sets Harry and Miss Simmons apart from the society around them. The two communities speak the same language, but they understand different things by it, in the same way that - at the story's beginning - Tommy and $\mathrm{Mr}$ Barlow had very different understandings of gentlemanliness. There is disjuncture. There is no mutuality. There is - in the context of Sandford and Merton, a book which is confessedly about conjunction - a disaster waiting to happen.

The first prominent example of this disunion's implications arises when Mrs Merton and Mrs Compton allude in conversation to what they perceive to be the merits of the young Lord Squander. (TD, II, p. 235) Miss Simmons interjects herself into their eulogizing discussion to balance it with some more negative reflections on the Lord's character that she has derived from her cousin's first hand experience of him. The list of vices which Miss Simmons 
attributes to Squander is considerable. He has little genius and less application. He is a gamer and a horse-racer. He manages, despite his large allowance, to remain perpetually in debt. His word has been broken so frequently that it can no longer be regarded as authoritative:

Added to this, [Miss Simmons has] heard that he is so haughty, tyrannical, and overbearing, that nobody can long preserve his friendship, without the meanest flattery and subservience to all his vitious inclinations. And to finish all, that he is of so ungrateful a temper, that he was never known to do an act of kindness to any one, or to care about any thing but himself.

$$
\text { (TD, II, p. 237) }
$$

By anybody's standards, these are strong slurs on a young man's character, and, given his absence, one would expect those present who appreciate him to refute them on his behalf. This, however, is not quite what happens, as Miss Matilda leaps to Squander's defence:

Miss Matilda could not help interposing with warmth: she said, that his lordship had nothing in his character, or manners that did not perfectly become a nobleman of the most elevated soul. Little, groveling minds, indeed, which are always envious of their superiors, might give a disagreeable turn to the generous openness of this young nobleman's temper. That as to gaming and running in debt, they were so essential to a man of fashion, that nobody who was not born in the city and oppressed by city prejudices, would think of making the least objection to them. She then made a panegyric upon his lordship's person, his elegant taste in dress, his new phaeton, his entertaining conversation, his extraordinary performance on the violin, and concluded that, with such abilities and accomplishments, she did not doubt of one day seeing him at the head of the nation.

$$
\text { (TD, II, pp. 237-8) }
$$

In this counterargument, Miss Simmons' accusations against Squander - when they are actually mentioned - are revalued rather than rebutted. The supposed faults in the Lord's temper are transferred from him to the little and envious minds of those who interact with him. His gaming and indebtedness are accepted not as vices but as attributes for a man of fashion. The remainder of Miss Matilda's commentary dissolves into insignificant fripperies before culminating in the hyperbolic suggestion that it in some way qualifies Squander to be 
an eventual leader of the country. Miss Matilda has attempted - although she probably would not see it like this - to reconfigure vices as virtues and folly as wisdom. She has shown simultaneously that she has not understood the accusations made against the defendant by Miss Simmons (because she has not effectively engaged with and contested them), and that her discourse is riddled with the exaggeration and imperception of sensibility. In a book which loathes all forms of sensibility, this sets a substantial gulf between Miss Simmons and Miss Matilda, and damns the latter as a character who should be given no credit.

Although Squander himself does not figure directly in Sandford and Merton, he is given an immediate analogue after the above exchange in the form of Master Mash:

Master Mash was the son of a neighbouring gentleman who had considerably impaired his fortune by an inordinate love of horse-racing. Having been from his infancy accustomed to no other conversation than about winning and losing money, he had acquired the idea that to bet successfully was the summit of all human ambition. $\mathrm{He}$ had been almost brought up in the stable, and therefore had imbibed the greatest interest about horses; not from any real affection for that noble animal, but merely bacause [sic] he considered them as engines for the winning of money.

(TD, II, p. 241)

Master Mash is off to a very bad start, because his love of horse-racing and of gaming implicitly puts him alongside the already established negative character of Squander. Mash gets no better as he is given more narrative time: he is usually to be found as the ringleader of the troublemakers who do their best to steer Tommy down the path of bad behaviour at the end of volume two. Harry often intercedes in this process, both on behalf of his friend (who ignores him) and on behalf of those who are going to be wronged by the naughtiness of the young gentlemen, but Harry is still at this time playing the role of the voiceless alien and so his Barlowian words go unheeded. The distance which opens up between Harry and Master Mash is comparable to if not greater than that which existed between Miss Simmons and 
Miss Matilda. In fact, the earlier argument between the girls serves to accentuate the later arguments between the boys.

Day's history, though, is of Sandford and Merton and not of Sandford and Mash, and the relationship between the latter is only important because of what it does to the relationship between the former. Master Mash's influence on Tommy effectively breaks down Tommy's respect for Harry, which leads to Tommy's ultimate fall from grace:

No, Master Tommy, answered Harry, it is you and your friends here that insult me. What, answered Tommy, are you a person of such consequence, that you must not be spoken to? You are a prodigious fine gentleman indeed. - I always thought you one, till now, answered Harry. - How, you rascal, said Tommy, do you say that I am not a gentleman? - Take that, and immediately struck Harry upon the face with his fist.

(TD, II, pp. 291-2)

The symbolic regression of Tommy's words is absolutely clear. He is back again, after two volumes of education, to being stuck on the issue of his supposed gentlemanliness. Harry, until this point, had regarded him as a true gentleman (a proper gentleman, a Barlowian gentleman) but the sort of gentleman that Tommy at this moment wishes to be is a gentleman of sensibility (the sort of gentleman that he was at the story's beginning). The conjunction between Sandford and Merton is split asunder with Tommy's fist and a wedge is driven between them. Harry is made utterly monstrous, because, for the moment, Tommy is lost to his new community of young gentry.

Harry, however, is not as willing to give up on Tommy as Tommy appears to be to give up on Harry, and a fight subsequently ensues between Harry and Master Mash, which Harry resoundingly wins. Immediately afterwards, Harry - with the assistance of a poor black to whom he had earlier given a little money - saves Tommy from a bull which runs wild at a local bull-baiting. Harry then leaves with the black - the social outcast accepting the social and racial outcast - and returns not to the Mertons' but to his own father's house. Sandford and Merton's second volume ends and another phase of its story is completed. Harry, the 
former pariah of the gentleman's household, has confirmed Tommy's safety and has reestablished himself through his acceptance of a new - and equally monstrous - friend. Harry has been the monster, been the lonely one, and has worked his way through it.

Tommy, by comparison, has not. He, in fact, has worked his way back into it. His position is now perhaps more difficult than it ever was because he has rejected both his best friend and the conjunctive essence of the title of the book in which he features. He is now slammed back into the position of difference at which he started and must begin again on his journey towards Barlowian redemption. His first step on this course is swift to come when, upon his return to his house after having been injured by the bull, his mother launches into a vitriolic diatribe against Harry because she has it on the authority of a maid that it was he who led her son into danger at the bull-bait. Tommy, however, now enlightened in Harry's absence by the magnitude of his friendship, quickly sets his mother right, and shoulders full responsibility for putting himself in danger:

Mrs. Merton stood amazed at this information; for her prejudices had operated so powerfully upon her mind, that she had implicitly believed the guilt of Harry upon the imperfect evidence of the maid...

Mrs. Merton was now silent with shame at reflecting upon her own unjust prejudices, and the ease with which she had become the enemy of a boy who had saved the life of her darling son; and who appeared as much superior in character to all the young gentlemen at her house, as they exceeded him in rank and fortune.

(TD, III, pp. 4-7)

Mrs Merton's condition here is by now readily recognizable as she is disqualified from and made silent in Day's narrative. Her son, shoved back into a position of demonstrative monstrosity as a result of his own wilful and selfish actions, has forced her - through his truthfulness - to engage too nearly with her own wilful selfishness. The full weight of her prejudices is brought to bear on her and the realization of her injustice is too much for her character to take. Unlike Tommy, Mrs Merton never gets the chance to regain and change 
her voice, and the muting of her previous verbosity at this point symbolizes everything from which Tommy must use the duration of Day's third volume to escape.

And, of course, escape Tommy eventually does, for the simple reason that he is sensible of the wrong that he has done and resultantly desires to put it right. When Mr Merton confronts Tommy with the baseness of his behaviour towards Harry, and Tommy bursts into a fit of crying, the ladies who are in attendance agree 'that there was no crime he could have been guilty of which was not amply atoned for by such a charming sensibility.' (TD, III, pp. 8-9) The irony in this phrase could not be more pronounced, because the response which they misread as an act of sensibility is actually the opposite: it is an act of very good sense. Tommy is right to cry, not because he is seeking attention in the self-serving manner of sensibility but because he is sensibly aware that he has done something very foolish and is contrite about it. Time after time in Sandford and Merton's third volume, this contrition is used actively to slough off the skin of his previous character - quite literally, by brushing the powder from his hair and by removing the fripperies from his clothing - and to draw on the mantle of the new. (TD, III, p. 255) Even after this demonstration, his mother still does not understand, still cannot see what Tommy is showing to her in his isolation, and tells him that he looks 'more like a ploughboy than a young gentleman.' (TD, III, p. 256) Yet, of course, for Tommy, this is exactly what he wants because his long-misvalued definition of what it is to be a gentleman has now finally been solidified into something more hopeful. The new Tommy is able to give of himself generously, both financially (to help the destitute) and physically (to help people or creatures that are in danger). (TD, III, pp. 97-101) The new Tommy is prepared to talk to his mother about what he now considers to be his life's faults, and to tell her - albeit with desperate solemnity - about the ways in which he proposes to change them. (TD, III, p. 256) Above all, perhaps, the new Tommy can sit down and listen to those so far beneath his social - and, indeed, in eighteenth-century England, racial - station 
that he would probably not before have even credited them with having a voice. As Tommy listens enraptured to the life-story of the bull-fighting black, (TD, III, pp. 276-95) his metamorphosis is almost complete:

The foolish distinctions which pride had formerly suggested were gradually obliterated from [Tommy]'s mind. Such a change in his sentiments rendered him more mild, more obliging, more engaging than ever... and Harry, although he had always loved him, now knew no limits to his affection.'

$$
\text { (TD, III, pp. 295-6) }
$$

Tommy's sentiments ${ }^{50}$ have become more sensible with the collapse of his pride and the loss of his sensibilities: the sequence could not be written more clearly. At the end of the book, although Harry and Tommy go their separate ways, it is to Harry not Mr Barlow that Tommy addresses his final eulogy, and it is to Harry that Tommy says he will return if he is ever in need of further instruction. (TD, III, 308) Mr Barlow's purpose has been achieved and his character takes a quiet back seat to the solidified and blessed friendship between Harry and Tommy, which truly, logically, and dialogically draws The History of Sandford and Merton to a close.

\section{(iii) 'The Great Business of Education'}

Although Day hopes that 'nobody will consider [it] as a treatise on education,' it is quite clear that Sandford and Merton is designed to have an educational function. It may be a stated work of children's literature and the theoretical subject of education may not frequently enter into its subject matter, but it is nevertheless meant to educate. This is not, even slightly, to give credit to the suggestion that Sandford and Merton is derived solely

\footnotetext{
${ }^{50}$ Note that Tommy's sentiments here are regarded as a positive thing, and that Mr Barlow previously recommends to Mr Merton that he should take advantage, for the purposes of improving his boy, of Tommy's sentiments of shame in the wake of his shabby treatment of Harry. (TD, III, p. 23) By comparison, in Sandford and Merton's preface, Day slams the vacuousness of sentimental novels. (TD, I, p. v) We may take it, therefore, that the distinction between positive sentiment and negative sentimental is one that Day understood too.
} 
from Rousseau's educationalist Émile, because that proposition has been shown to be both inaccurate and unjust. Even if there were nothing else to distinguish the two books, the basic differences of approach that are signalled in their respective titles would do the job perfectly well: Émile is a monologic text, with Émile - on his own - being dictated to without discussion by Jean-Jacques; Sandford and Merton is a dialogic and reciprocal text, which aims unmistakably to establish and celebrate the conjunction between its two child protagonists that is proclaimed in its title. What Day has achieved is what Mr Barlow refers to as 'the great business of education to apply such motives to the imagination, as may stimulate it to laudable exertions.' (TD, III, p. 22) In other words, if something is going to educate then it has got to get its audience thinking in a positive way. For Tommy, education takes the form of removing, re-establishing, and then removing again the isolation from true friendship that Sandford and Merton associates with wanton sensibility. For Harry, education is to stay true to the sensible and unspoilt principles that he believes to be correct, no matter - and, on occasion, because of - the hardships and isolation that they impose upon him. Both boys experience the stigma of social deviance within the other's social community. Both are, therefore, made monstrous by social circumstances, and find the lessons of that monstrosity hard. For all of what can now be regarded as its conservatisms, didacticisms, and hyper-moralizations, the hardness of these lessons resolves Sandford and Merton as a profound and unsettling text, which tackles head-on the issues that arise from finding and losing one's social context. 


\section{CHAPTER FOUR}

ANNA LAETITIA BARBAULD: DOUBLE DISSENSION 
The selection of Anna Laetitia Barbauld's children's literature which is to be examined here the Lessons for Children series and Hymns in Prose for Children - was all published either before or during the publication period of Day's Sandford and Merton. There are, however, good reasons to discuss it after rather than before Day's work. Sandford and Merton is more representative of late eighteenth-century England's new breed of children's literature, as described in chapter two, than either Lessons for Children or Hymns in Prose. Sandford and Merton is typical of its time as a fully developed and complex narrative text. Barbauld's writing is not because, unusually for this period, it is intended explicitly for very young infants. Barbauld caters for a highly specific, perhaps even a not-yet-literate audience, by comparison to the more general and more erudite readership that is targeted by most other instances of popular eighteenth-century English children's literature (including, Sandford and Merton). Barbauld, then, is best examined in the light of having already thought about Day rather than vice versa: Day provides a context for Barbauld which would be far less effective if reversed.

There are, as well, a number of intriguing biographical parallels between these two writers, the most notable of which is their mutual suffering of the difficulties associated with social abnormality. In Barbauld's case, though, this aberration exists for very different reasons and is manifest in very different ways to that which causes problems in the case of Day. Barbauld's difference, her monstrousness, results from the machinations of a two part contextual schism. The first of these is biographical and religious. The second is literary and chronological. These traits emerge in her writing for children as problematic disjunctures, and it is the repercussions of these divisions that this chapter will analyse. 
Anna Laetitia Aikin was born on $20^{\text {th }}$ June 1743 into a family of Dissenters. Her father, John Aikin, had been a Presbyterian minister in the small Leicestershire town of Kibworth Harcourt, but, after his health became too frail for him to maintain this clerical vocation, he opened and ran a small school for boys. By the time his children were born - first Anna and then John four years later - Aikin had established for himself an excellent reputation as a nonconformist educator. This religious background was evidently one which Anna took to heart, in spite of the socially disenfranchising implications of Dissenting affiliations (which resulted from the then still active anti-nonconformist statutes from the end of the previous century). In 1774, she married Rochemont Barbauld - a Dissenting minister of French descent, who was six years her junior - and she maintained her parents' religious preferences throughout her life's work as an authoress and an educator. Like that of her more frequently studied contemporary, Hannah More, Anna Laetitia Barbauld's written output, primarily under her married but also under her maiden name, was prodigious and varied. She can be described justifiably as a poet, an essayist, a critic, an editor, a pamphleteer, a hymnist, and a writer for children.

Also like More, Barbauld was, in her time, a considerable literary celebrity. Following her move to Warrington at the age of fifteen, which occurred because her father accepted a post at the town's newly opened Dissenting academy, she met and grew in friendship with Joseph Priestley. It was at Warrington that she began her most prolific period of poetic writing, for which Priestley, later recalling this time in his memoirs, takes upon himself no small degree of credit:

I was myself far from having any pretension to the character of a poet; but in the early part of my life, I was a great versifier, and this, I believe, as well as my custom of writing after preachers... contributed to the ease with which I always wrote prose. Mrs. Barbauld has told me that it was the perusal of some verses of mine, that first induced her to write any thing in verse, so that this country is in some measure indebted to me 
for one of the best poets it can boast of. Several of her first poems were written when she was in my house, on occasions that occurred while she was there. ${ }^{51}$

Regardless of the accuracy of Priestley's account of its origins, Barbauld's work was eventually published - after some cajoling from her brother - in Poems (1773). The praise which this volume received was fulsome, almost without exception, and is epitomized by the glowing commendation in the Monthly Review:

We congratulate the public on so great an accession to the literary world, as the genius and talents of Miss Aikin. We very seldom have an opportunity of bestowing praise with so much justice, and with so much pleasure. ${ }^{52}$

After this eulogy, which was so extensive that it needed to be split across two issues of the Monthly Review, the tributes to Barbauld from substantial literary figures came in thick and fast. Dr Johnson lauded an essay which she wrote in imitation of his own hand. ${ }^{53}$ Samuel Taylor Coleridge compared her favourably to Robert Hall (a Baptist pastor and celebrated preacher), ${ }^{54}$ walked the forty mile trip from Stowey to Bristol simply for the purpose of meeting her, ${ }^{55}$ and went on to become a vociferous advocate of her style. ${ }^{56}$ Even William

\footnotetext{
${ }^{51}$ Joseph Priestley, Autobiography of Joseph Priestley: Memoirs Written by Himself / An Account of Further Discoveries in Air, intr. Jack Lindsay (Bath: Adams \& Dart, 1970), p. 89.

52 Anon., 'ART. XI. Poems. By Miss Aikin, concluded: See our last Month's Review,' Monthly Review, 48 (Feb. 1773), 133-7 (p. 37).

${ }^{53}$ James Boswell records that Johnson attacks Hugh Blair, for Blair's lecture-based attempts to reproduce the Johnsonian style, by saying, 'Sir, these are not the words I should have used. No, Sir; the imitators of my style have not hit it. Miss Aikin has done it the best; for she has imitated the sentiment as well as the diction.' (Samuel Johnson, in James Boswell \& Samuel Johnson, Boswell's Life of Johnson Together with Boswell's Journal of a Tour to the Hebrides and Johnson's Diary of a Journey into North Wales, ed. George Birkbeck Hill, rev. L.F. Powell, 6 vols (Oxford: Clarendon Press, 1934), hereafter $S J$, III, p. 172)

${ }^{54}$ 'I wish that I could reach the perfection of his style. I think his style is the best in the English language - if he have a rival, it is Mrs. Barbauld.' (Samuel Taylor Coleridge, 'To Benjamin Flower, April 1, 1796,' in Collected Letters of Samuel Taylor Coleridge, ed. Earl Leslie Griggs, 6 vols (Oxford: Clarendon Press, 1956), I, hereafter SC, p. 197)

${ }^{55}$ Writing a footnote to a letter of Coleridge's, dated 19 August, 1797, Earl Leslie Griggs states that, 'On his arrival at Stowey, Coleridge found Richard Reynell there on a visit. Reynell's letter to his sister also describes Coleridge's journey from Bristol: "On my arrival at Stowey and at Mr. Coleridge's house I found he was from home, having set out from Bristol to see Mrs. Barbauld a few days before... He returned on Saturday evening after a walk of about 40 miles in one day apparently not much fatigued."' (Earl Leslie Griggs, in $S C$, p. 341)

56 "The more I see of Mrs Barbauld the more I admire her - that wonderful Propriety of Mind! - She has great acuteness, very great - yet how steadily she keeps it within the bounds of practical Reason. This I
} 
Wordsworth - never the most generous of critics - could not resist offering a half-compliment

on the final stanza of 'Life.

Alongside these acclamations, however, disparagement was never far away. Johnson, in

particular, lost the faith after Barbauld's marriage:

Miss [Aikin] was an instance of early cultivation, but in what did it terminate? In marrying a little Presbyterian parson, who keeps an infant boarding-school, so that all her employment now is, "To suckle fools, and chronicle small-beer." She tells the children, "This is a cat, and that is a dog, with four legs and a tail; see there! you are much better than a cat or a dog, for you can speak." If I had bestowed such an education on a daughter, and had discovered that she thought of marrying such a fellow, I would have sent her to the Congress.

$$
\text { (SJ, II, pp. 408-9) }
$$

In addition to this, Charles Lamb's lambasting of Barbauld - ironically enough, in a letter to Coleridge - has become so famous that scholars of all three writers now quote it ubiquitously:

Mrs. Barbauld's stuff has banished all the old classics of the nursery; and the shopman at Newbery's hardly deigned to reach them off an old exploded corner of a shelf, when Mary asked for them. Mrs. B.'s and Mrs. Trimmer's nonsense lay about in piles. Knowledge insignificant and vapid as Mrs. B.'s books convey, it seems, must come to a child in the shape of knowledge, and his empty noddle must be turned with conceit of his own powers when he has learnt that a Horse is an animal, and Billy is better than a Horse, and such like; instead of that beautiful Interest in wild tales which made the child a man, while all the time he suspected himself to be no bigger than a child... Damn them! - I mean the cursed Barbauld Crew, those Blights and Blasts of all that is Human in man and child. ${ }^{58}$

almost envy as well as admire - My own Subtleties too often lead me into strange (tho' God be praised) transient Out-of-the-waynesses.' ('To John Prior Estlin, March 1, 1800,' in SC, p. 578)

57 'Life' was first published in the 1825 two volume The Works of Anna Laetitia Barbauld. With a Memoir by Lucy Aikin, in which its position - according to Barbauld's modern editors - suggests a date of composition ca. 1812. (William McCarthy \& Elizabeth Kraft, in Anna Laetitia Barbauld, The Poems of Anna Letitia Barbauld, ed. William McCarthy \& Elizabeth Kraft (Athens: The University of Georgia Press, 1994), p. 318) Of 'Life,' Henry Crabb Robinson records that Wordsworth said: "'Repeat me that stanza by Mrs. Barbauld." I did. He made me repeat it again, and so he learned it by heart. He was at that time walking in his sitting-room at Rydal with his hands behind him, when I heard him mutter these words to himself: "I am not in the habit of grudging people their good things, but I wish I had written those lines."' (Henry Crabb Robinson, On Books and Their Writers, ed. Edith J. Morley, 3 vols (London: J.M. Dent \& Sons, 1938), I, p. 8)

${ }^{58}$ Charles Lamb, 'To S.T. Coleridge, October 23, 1802,' in The Letters of Charles and Mary Lamb, ed. E.V. Lucas, 3 vols (London: J.M. Dent \& Sons, 1935), I, p. 326. Sarah Trimmer, a contemporary of Barbauld's, is the subject of this thesis' next chapter. 
So, after accepting Barbauld's early work with such positivity, her contemporary literary community - represented here by, but by no means limited to, Johnson and Lamb - fell into a quagmire of indecision about the way in which it should receive and treat this new authoress. The reason that Johnson and Lamb are exceptionally interesting in this context is that they condemn the exact same branch of Barbauld's work, i.e., her children's literature, for what appear to be the exact opposite reasons. Why, one wonders, should this be?

The answer is that Johnson and Lamb are representatives of the two (albeit notionally broad and then unqualified) dominant literary factions of their day - Augustanism and Romanticism - and that Barbauld's children's literature fits satisfactorily under the auspices of neither. Both Johnson and Lamb, it should be noticed, fashion their attacks around not only Barbauld's children's literature but the very same aspect of it (its ostensible simplicity) before they subsequently diverge. For Johnson, the nominal Augustan, a lack of willingness to engage with the imaginative potential of Barbauld's work prevents him from seeing beyond its plain monosyllabism to the full implications of the inter-special comparisons and interrelations that it proposes. Such metaphors constitute, for Johnson, a step too far down the road to childishness and they condemn Barbauld's tracts as the products of hypothetical imaginative silliness. For Lamb, the nominal Romantic, an inability to connect with the practical moral lessons in Barbauld's writing makes him see in it nothing other than excessive dryness, insufficient expanse, and - above all - a want of imagination. There is a mutual philosophic exclusivity here, between the (again, broadly) down-to-earth common sense of Augustanism and the vaunting imaginative landscapes of Romanticism. Barbauld's children's literature is stuck somewhere between the two.

Distillation of this contextual material leads to the conclusion that Barbauld, especially with respect to her children's literature, should be regarded as a double dissenter (a double monster - a figure who stands out). Biographically, she was a Dissenter, in the proper noun 
and religious sense of the word, and literarily, she was a dissenter, as one whose chronological positioning situated her between two literary movements into neither of which her children's literature fitted. There is self-evident potential for a figure of such dual difference to be marginalized by his or her contemporaries: it is notable that Johnson derides Barbauld as much for her decision to marry 'a little Presbyterian parson' as he does for her writing of unfussy tracts for infants; as much for her religious dissension as for her literary dissension. The overall result of this twofold schism has been to produce a rift in Barbauld's literary reception which has never been truly resolved, and which even, whether or not she knew it, affected her writing during its production. The nature and implications of this double dissension's manifestations are particularly fascinating, because - as will be shown they were of sufficient force to cause a palpable shift in Barbauld's method of composing her literature for children.

\section{(ii) The Voices of Authority: Lessons for Children and Hymns in Prose}

After the publication of Poems in 1773 and her marriage the following year, Barbauld relocated to Palgrave in Suffolk where she assumed with her husband the joint management of a Dissenting boarding school for boys. Her next major publications - her first as a married woman - were the Lessons for Children series (1778-9) and Hymns in Prose for Children (1781). These were books designed to function jointly as educative tools for the boys in her school and, especially in the case of Lessons for Children, for her adopted son, Charles Rochemont Aikin. Charles was born in 1775, the third son of Barbauld's brother John. Barbauld and her husband adopted him in 1777, and it is consequently assumed that he provided at the very least a model for the Charles to whom Lessons for Children are addressed. It may be taken, therefore, that the Lessons for Children enterprise has a dual purpose. It is simultaneously public and private, professional and familial: 
This little publication was made for a particular child, but the public is welcome to the use of it. It was found that, amidst the multitude of books professedly written for children, there was not one adapted to the comprehension of a child from two to three years old. A grave remark, or a connected story, however simple, is above his capacity; and nonsense is always below it; for Folly is worse than Ignorance. Another great defect is the want of good paper, a clear and large type, and large spaces. They only, who have actually taught Young children, can be sensible how necessary these assistances are. The eye of a child and of a learner cannot catch, as ours can, a small, obscure, ill-formed word, amidst a number of others all equally unknown to him. - To supply these deficiencies is the object of this book. The task is humble, but not mean; for to lay the first store of a noble building, and to plant the first idea in a human mind, can be no dishonour to any hand. ${ }^{59}$

There are striking similarities between these self-justifications of Barbauld's project and those which would later be published by Day in his preface to Sandford and Merton. Both writers complain of the contemporary want of appropriate books with which to educate children. Both avoid expressions of interest in theories of education, but both very clearly want to educate and demonstrate. Both target children as their implied audiences. However, Barbauld's preface differs from Day's in its privileging of the linguistic and bibliographical presentation of Barbauld's material, which stems from her desire to make her books legible and appealing for young minds. Very young minds, in fact, because the Lessons for Children series is confessedly aimed at three separate but narrowly proximal age groups: two to three years, three years, and three to four years. This segregation speaks volumes about Barbauld's thinking on the ways in which children form in relation to literature. The fact that she sees a need for three age-directed Lessons for Children, in spite of their age ranges' closeness to each other, means that she must regard each of her three chosen groupings as distinguishable developmental stages in young people. Barbauld sees infant learning as an identifiable, precise, and linear process. She feels that it is best to engage with this through a series of identifiable, precise, and linear lessons.

\footnotetext{
${ }^{59}$ [Anna Laetitia Barbauld,] Lessons for Children, from Two to Three Years Old (London: [printed for] J. Johnson, 1787), hereafter $L C 2$, pp. 3-4.
} 
All this being said, it is easy to form an expectation that Barbauld's approach to child development in Lessons for Children will be pedantically meticulous. Precise lessons for children of two to three years, three years, and three to four years do not seem to leave much scope for enjoyable follies or flights of fancy. These books look as though they are going to be sensible, logical, clear, consistent, and dull. Perhaps Lamb's Romantic lampooning of Barbauld is going to be justified after all.

And, in fact, none of these anticipations strays too far from the truth, at least in terms of the books' structures. The three Lessons for Children, true to the simultaneously personal and private applications of their claimed inception, are written consistently and exclusively in a reciprocal and conversational style to a child called Charles. Their formats, in the main, comprise questions, answers, and explorations, with occasional pauses for expository stories. Their narratives are delivered primarily from the point-of-view of parent or guardian figures. All of these static features, coupled with a self-confessed desire to be attractive and readable to young children, combine to construct these books as texts which are intended to be read aloud to a child by an appropriate adult, with the child reading - whether silently or not alongside. The child can then identify with the authoritative voice of the reading narrator whilst enjoying and benefiting simultaneously from the books' physical features.

This voice of demonstrative authority, however, unearths a serious problem, remembering that the established expectation for these texts is of logicalness, clearness, consistency, and linearity. Consider the following extract from the early stages of Lessons for Children, from Two to Three Years Old:

I want some wine.

What, wine for little boys! I never heard of such a thing. No, you must not have wine. Here is water.

Do not stand so near the fire. Go to the other side.

Do not tread upon mamma's apron.

Go away now, I am busy. 
The linguistic clarity of this extract cannot be queried, as it is lexically easy and syntactically simple. Nevertheless, it is far from being either logical or linear. Charles opens the discourse with a request for wine, to which his unnamed guardian responds with a stated question (of which the exclamatory rather than interrogative tone linguistically precludes the possibility of an answer) and a sequence of negatives. Water is then provided instead of wine and the boy is thereby summarily dismissed. However, the adult continues afterwards to address Charles in imperatives, for which no direct explanations are offered: 'do not stand near the fire,' etc. It is easy enough to imaginatively interpolate circumstances that would justify such instructions, but - as far as the actual written text is concerned - linearity nevertheless breaks down. This, therefore, is not logic. It is a series of commanding nonsequiturs.

The importance of this scene cannot be overstated because it is a clear example of logical implosion in what is professedly, even essentially, a logical book. Charles' whim for wine is turned down, perhaps not unreasonably for a child of merely two to three years, but he is then faced with a series of unlinked instructions which culminate in an unqualified statement of rejection: 'go away now, I am busy.' His participation in this process presents him with all sorts of insoluble questions. Does the adult's sudden business result from his initial misdemeanour of requesting wine? Does it result from his incorrect location with respect to the fire? Does it result from something else to which neither he nor indeed his reader are privy, and which perhaps has nothing to do with him at all? Each of these questions is unanswerable because this scene is neither linear nor logical and because there is so much about it which is left unsaid. Indeed, perhaps the only certainty about this scene is that, in its lack of linearity and logicalness, it can be best described as being very human.

In brief, the net result of this demonstrative sequence is very simple: Charles is - without clarification - shut out from the text, told to go away, isolated, and made alien. The 
education of children through Lessons for Children is subsequently problematized by the fact that adults, no matter how much they aspire to linearity and logic for the sake of transparency, are actually illogical, unpredictable, and potentially hurtful creatures. What this scene purports to show is a dialogue between a child and an adult, but what it truly shows is the voice of a child being rendered unexplainedly subordinate to that of an adult. It consists rather of a monologue than a reciprocal dialogue, as though the adult is prepared to interact with Charles to only a mysteriously limited extent. The implied justification for this must be that a child of two to three years is too young to understand all of the logic which contributes to adult commands, but yet there runs concomitant with this an unspoken suspicion that the true reason behind it is that the only way in which adults can maintain authority over children is by commanding not illuminating them. The voice of authority in Lessons for Children effectively produces a clash with the books' professed educative methodology: control not mutuality seems to be the name of the game here.

Thus, within what initially appears to be the overtly Augustan framework of Lessons for Children, young people (unwittingly) acquire the potential to ask difficult and expansive questions of their adult educators. Why do adults, for example, when faced with an interactive situation involving children that demands an explained resolution, leave behind linearity and logic and resort instead to unreasoned imperatives? Could it be that adults do not actually adhere to linearity and logic themselves? Could it be that some adult requests if explained fully - might have no better justification and no less caprice to support them than those of a young child who bullishly requests a cup of wine? The presence of the child here quite clearly threatens and shows up the adult. The adult who is supposed to be demonstrating instead becomes subject to the demonstrative pressure of the child. The only way in which the adult can respond to this is by restating its authority over the child through 
a series of domineering (though not necessarily relevant) imperatives, because these will silence the child and thereby take away the voice of difficulty.

If the textual example that we have looked at thus far may be taken as representative, then we may deduce that comparable problems, comparable inconsistencies, are likely to arise in Lessons for Children in situations that demand dialogue or interactivity between adults and children. Consistent with this expectation is the fact that the beginning of Lessons for Children, of Three Years Old presents no such difficulties because it simply functions to situate Charles chronologically and physically in relation to his surroundings (through an explanation of days, weeks, and months, and a list of the differences between humans and animals). Sequentially, this is absolutely logical, absolutely clear, and demands no dialogue whatsoever. It starts with a basic and comprehensible description of the western calendar:

It is January. It is very cold. It snows. It freezes. There are no leaves upon the trees. The oil ${ }^{60}$ [sic] is frozen, and the milk is frozen, and river is frozen, and every thing. ${ }^{61}$

This vein continues to produce a month-by-month summary of the year. February is associated with yellow crocuses, snow drops, and cawing rooks; March is associated with young lambs and primroses; April is associated with singing birds and blossoming trees; and so it continues. These statements are purely factual. They are delivered - by and large - in simple sentences, and they demand no interactive, no emotional, explanation.

However, having established the principle of using the natural world as a chronological locator, the narrative subsequently expands to incorporate a sense of humanity's benevolent stewardship over nature. Suddenly, as humanity re-enters the text, things once again start to unravel. Take the example of the fallen fledglings, which, according to the adult narrator, must be cared for because 'the little birds [sic] papa and mamma will be very sorry if they

\footnotetext{
${ }^{60}$ This is probably meant to read 'the soil is frozen,' unless, at the end of the eighteenth-century, Palgrave was somehow not beholden to the established laws of physical chemistry.

${ }^{61}$ [Anna Laetitia Barbauld,] Lessons for Children, of Three Years Old. Part I [II], 2 vols (Dublin: R. Jackson, 1779), hereafter $L C 3, \mathrm{I}, \mathrm{p} .9$.
} 
come to die.' ( $L C 3$, I, p. 18) So far, so good, but, when the narrator and Charles later encounter a dying fish, the discourse crunchingly changes gear:

Here is a fish that somebody has caught: Poor little fish! Throw it on the grass. See how it flounces about! It has a hook in its gills. Take it by the tail; it is slippery, you cannot hold it. See, these are fins. It has got fins to swim with; and it has got scales, and sharp teeth. It will be dead soon. It is going to die. It cannot stir any more. Now it is quite dead. The fish dies because it is out of the water, and Charles would die if he was in the water.

$$
\text { (LC3, I, pp. 48-9) }
$$

Charles learns a good and important lesson here, in that he now knows that he is not like a fish and that he therefore cannot exist easily, if at all, in water. Letting the fish die, though, is far from essential to the successful acquisition of this knowledge, particularly since - when juxtaposed with the fledgling incident - there is now a marked discrepancy between the ways in which Charles has been taught to treat metaphorical and literal fish out of water. In fact, the brutality of the imperative, 'throw it on the grass,' as the direct successor to an exclamatory expression of sympathy with the fish, emphasizes the fact that this scene is unfolding in direct contravention of the compassion encouraged under the comparable circumstances of Charles' lesson with the fledglings. For the sake of consistency, it would have been more appropriate to command Charles to return the fish to the water, but the narrator chooses instead to dwell for multiple sentences upon the fish's death-throws:

It will be dead soon. It is going to die. It cannot stir any more. Now it is quite dead.

The brusqueness of these short simple statements underlines the pragmatic fact that human interrelations with animals are as full of contradictions and variations as human interrelations with each other. What is good enough for little birds, apparently, is not good enough for a fish. Yet, in teaching that this is so, Lessons for Children does not explain why this should be and by what terms such interrelations can be governed. The child (both the in-text 
Charles and potential external reader) is caught in the middle of what claims to be a logical exercise in linear educative exposition but which seems paradoxically to be fast becoming an act of irresolvable obscurity.

Trying to find a solution to this obscurity, particularly in Lessons for Children, is very difficult, because the underlying (perhaps even the unconscious) theme for this series seems to be that nature, whilst undoubtedly red in tooth and claw, is far from fair in logic and justice (in the moralistic human sense). In addition to the fledglings and fish incidents, the recurring character of Puss also goes a long way towards demonstrating this truth:

Ask puss to teach you [how to climb trees]; she can climb... She wants to catch birds. Pray puss do not take the little birds that sing so merrily! She has got a sparrow in her mouth. She has eat it all up. No, here are two or three feathers on the ground all bloody. Poor sparrow.

$$
\text { (LC3, I, pp. 53-4) }
$$

By observing Puss, Charles may learn a little about how to climb trees, but he will also learn - if indeed he has not already inferred this - that the nominally just cause of supporting the weak is not promoted by all of nature's participants. Puss needs to eat and she will therefore catch birds. For her, this primal logic takes precedence over the moral logic of protecting the birds that are weaker than her (from which process she would get no material gain). This selfsame quandary, as William McCarthy points out, occurs earlier in the series as well when Puss kills a rabbit:

There is much more here than death to notice. The question put to Puss, "Why did you kill the rabbit?" is both funny and profound. It is profound because it points towards ultimate issues: why are cats permitted to kill rabbits? Why is cruelty in the world? Or $i s$ it cruelty for one animal to kill another? Puss is supposed to catch mice, not kill rabbits - but "supposed" by whom? Is it part of the Divine Plan that cats are ordained to catch mice, or is it rather that human beings demand certain behaviors of them and condemn others? Is Puss guilty? The question is funny because, of course, Puss can't answer it. Everybody knows you do not ask animals to account for their actions - 
everybody, that is, except two year olds like Charles, who do not yet realize that animals lack speech. "Puss cannot speak," and that ends the discussion. ${ }^{62}$

Once again, as in the case of Charles' request for wine, a number of irresolvable questions arise from this scene. The adult educator is faced with the enormous profundity of being asked indirectly to engage with ultimate issues as a result of a direct query to a cat which everybody knows that the cat cannot answer. Everybody, that is, except Charles. Once again, a simple and childish question - 'Why did you kill the rabbit?' - pushes the adult towards irresolvable complexity. Once again, the child's presence unacceptably threatens the adult's integrity. Once again, the child is made monstrous.

In summary, Lessons for Children has a problematic tendency to imply or encode more than it is actually prepared to deal with. It is, as McCarthy puts it, 'much more than a reading primer,' since it also introduces elements of society, symbolisms, conceptual structures, and ethics. $(M D)$ The trouble is that myriad complexities abound where humanity is required to interact either with itself or with nature, so an authoritative adult voice becomes necessary in order to cut these off. Statements of fact cause no difficulty. Statements of fact in a discursive context do. The abstract lack-of-fairness theme that recurs unerringly in Lessons for Children jars against the claimed linear logicalness of the series' approach to produce a hotchpotch sequence that presents more questions than it successfully answers. In doing so, to reiterate, it is deeply human, but its effect is consistently to distance its audience of children by keeping them necessarily subordinate to the self-referential, controlling, but really quite vulnerable voice of authoritative adulthood. Lessons for Children simultaneously justifies and refutes the criticisms of both Lamb and Johnson: it posits imaginative expanse in one moment but then disables it in the next.

\footnotetext{
${ }^{62}$ William McCarthy, 'Mother of All Discourses: Anna Barbauld's Lessons for Children,' Princeton University Library Chronicle, 60.2 (Winter 1999), 196-219, http://ccl.princeton.edu/index.php?app=download\&id=100, hereafter $M D$. Pagination to a physical edition is not provided by the online service from which this essay was downloaded and is therefore not offered here.
} 
To understand how Barbauld moves on from this, there is a helpful point in the passage from McCarthy quoted above, which is taken no further in his essay but which is nevertheless highly significant here. He mentions the idea of 'the Divine Plan' with respect to the behaviour of cats in Lessons for Children. Barbauld, crucially, does not, either on the subject of Puss or indeed anywhere else in the Lessons for Children series. Neither God nor Christianity gets a look-in in these early books, and the closest Lessons for Children comes to engaging with theological material is in its story of the mischievous lamb which manages to get itself eaten by a wolf because it runs away from its (Christ-like) good shepherd. (LC3, II, pp. 36-48) Even this connection, though, is far from being clearly signalled because a good knowledge of New Testament imagery (unlikely in a three year old) would be required to comprehend its Christian link. This absence of religion is strange, given the production context of Lessons for Children as a series of tools which is designed at least in part to educate little boys in a Dissenting religious boarding school. In fact, it gets even stranger, because Barbauld's sequel to Lessons for Children, Hymns in Prose for Children by the Author of Lessons for Children, places great stress, even in its title, on its clear-cut religious affiliation (through its use of the noun hymns). The seeming generic paradox of hymns in prose is derived, according to Barbauld, from a desire to produce memorable hymnic devotional material for children which does not overbear them with the literary and linguistic excesses of poetic hymnody:

The Author of these Hymns has therefore chosen to give them in prose. They are intended to be committed to memory, and recited... The peculiar design of this publication is, to impress devotional feeling as early as possible on the infant mind; fully convinced as the author is, that they cannot be impressed too soon, and that a child, to feel the full force of the idea of God, ought never to remember the time when he had no such idea. ${ }^{63}$

\footnotetext{
${ }^{63}$ [Anna Laetitia Barbauld,] Hymns in Prose for Children by the Author of Lessons for Children
} (London: [printed for] J. Johnson, 1781), hereafter $H P$, pp. vi-vii. 
The purpose of Hymns in Prose, therefore, is to induct young minds into Christian thinking as soon as possible, which, from a writer who is a worker at a Dissenting boarding school and who comes from a background steeped in Dissenting education, seems perfectly sensible and perfectly logical. This, though, from the selfsame writer who published a series of lessons barely a few years earlier which made no direct mention of this Christian thinking, is much more peculiar. Here, it seems, is yet another inconsistency. Here is yet another breakdown in Barbauld's much prized logic.

It is worth emphasizing parenthetically that the disparity of religious presence between Lessons for Children and Hymns in Prose is made contextually more obvious than it otherwise might have been by the manifold features that the texts share. Structurally, Hymns in Prose is very similar to Lessons for Children, in that it operates through the same simple language, uses comparable natural metaphors and imagery, and maintains the presentational consistency which helped to make its predecessors so successful. The justification for its production is familiar too, which is that, although there are a number of books available which unfold the systems and doctrines of religion, there are very few 'to assist [children] in the devotional part of it, except indeed Dr. Watts' Hymns for Children. ${ }^{64}$ (HP, pp. iii-iv) Hymns in Prose even goes so far as to re-emphasize the importance of chronological situation, by spreading its broadly life-death-and-rebirth theological account across a calendar-reminiscent twelve hymn arrangement. In fact, the only major features which distinguish Hymns in Prose from Lessons for Children are that the former is written in a style of prose hymning which is reminiscent of bipartite parallelistic psalmic compositions (e.g., 'Come, let us praise God, for he is exceeding great; let us bless God, for he is very good' $(H P$, p. 1)), and that it includes the presence of God.

\footnotetext{
${ }^{64}$ Watts' Hymns for Children was republished soon afterwards by Hannah More's Cheap Repository.
} 
As has already been suggested, this presence of God in Hymns in Prose is actually a very big change from Lessons for Children but why it should suddenly be introduced into the later text is debatable. One explanation for it does seem particularly plausible, however, given Barbauld's literary context as one who worked between the modes of Augustanism and Romanticism. If it is accepted that the Lessons for Children were written by Barbauld with the intention of putting over the sort of simple and didactic educative content which Lamb went on to loathe, then the absence of God from them would be justified by the argument that the inclusion in them of things theological would have introduced precisely the sort of metaphysical and philosophical complexities which they were so determined to avoid. Unfortunately, this absence simultaneously leaves Lessons for Children without any objective authority beyond the word of its adult narrator, which we have already found to be incapable of bearing up against the strain which childish questions and even childish presence puts on it. Lessons for Children indirectly states that if a single adult is given authority under such circumstances then consistency, logic, and structure will collapse into autonomous individualism and whim. Who is to say what a cat can or cannot do, or why it is acceptable to watch a fish die but not little birds? Who is to say why it is inappropriate for a little boy to drink wine? Everything and everyone under such circumstances are reduced to a state of childishness because there is nothing which can be turned to for an expression of objective truth. In her life, one presumes, Barbauld would have looked to God for that truth, and so it is logical, sensible, and consistent she should insert God into her later educative children's literature in order to fill the authority vacuum that abounded in its earlier instances. Since we may take it that God was initially omitted from this earlier context because Barbauld considered the concept of God to be too problematic to embody within the literalism (Augustanism) of simple didactic prose, it is clear that a more imaginative (Romantic) framework will be required in order to represent him effectively. Thus we arrive 
at Hymns in Prose for Children, which will satisfy the need to maintain the structural simplicity established in Lessons for Children whilst offering the poetic scope that is required to ascend into the theistic abstract. Jerom Murch refers to a saying that Hymns in Prose is 'poetry in everything but the metre: ${ }^{65}$ the manifold implications of this description sum up most elegantly the shift in styles between Lessons for Children and Hymns in Prose.

This shift is easier to recognize when it is illustrated. Consider 'Hymn 1' from Hymns in Prose, which eulogizes natural features (e.g., sun and moon, whale and elephant, worms, birds, brooks, rivers, etc.) in a way that is in keeping with the precedents established in Lessons for Children. However, by taking these features and relocating them in the context of God's creation, the meaning of the descriptions associated with them necessarily undergoes a relocation as well:

The lambs just dropt are in the field... their young limbs can hardly support their weight.

If you fall, little lambs, you will not be hurt; there is spread under you a carpet of soft grass, it is spread on purpose to receive you.

$$
\text { (HP, pp. 8-9) }
$$

If this were an extract from Lessons for Children, the idea of grass being 'spread on purpose to receive' falling lambs would have been really difficult. In that context, the grass would have had its own more logical agenda, and would probably not have had much interest in providing a soft landing site for gambolling lambs. However, this extract is not from Lessons for Children, and the potential for such a hyper-literalistic interpretation of its content is negated in Hymns in Prose by the presence of God. Here, grass need not be a materialistic autonomous unit which functions merely to serve its own ends. Here, it can operate instead as a multi-purpose entity - as part of a wider schema in which there is an authority and purpose that is external to the earthly self - as a cushioning site for wobbly lambs as well.

\footnotetext{
${ }^{65}$ Jerom Murch, Mrs Barbauld and her Contemporaries; Sketches of Some Eminent Literary and Scientific Englishwomen (London: Longman, Green and Co., 1877), p. 74 (my emphasis).
} 
Why? Because God wills it to be so. There is no longer an obligation here for the narrating educator to provide an all-encompassing and reductive definition and explanation of everything. The child's imagination can now roam expansively across what it finds, and is permitted to discover indicators of a power, a knowledge, and a divinity which is beyond that of the educator. God is 'the shepherd's shepherd,' 'the parent of the mother,' and 'the sovereign of the king.' (HP, pp. 14-8) All authority is deferred to him:

[God] made all things, but he is himself more excellent than all which he hath made: they are beautiful, but he is beauty; they are strong, but he is strength; they are perfect, but he is perfection.

$$
\text { (HP, pp. 24-5) }
$$

God, then, is beyond comparatives and superlatives. He is the essential. He is not more beautiful than earthly beauty: he is, actually, beauty. He is not the strongest of earthly strengths: he is, actually, strength. God is the definition, the explanation, the rationale, and the justification, and it is the sum of these realizations that makes Hymns in Prose so much more logical, consistent, and linear than its predecessors. Hymns in Prose does not affirm that everything becomes rationally explicable when given a theistic context; rather, it belies the need for rational explicability. It encourages its implied audience to give to God those things which are incomprehensible, and to accept that - although the adult is a powerful and knowledgeable authority on Earth - the adult, and hence the child, can never be the be-alland-end-all. In Lessons for Children, the epithet 'child of reason' would perhaps have been a mantle of achievement and a title to be desired. In Hymns in Prose, it becomes a mark of fixity, beyond which the child is commanded to expand in order to aspire instead to a logic which is ruled by God:

God is in every place; he speaks in every sound we hear; he is seen in all that our eyes behold: nothing, O child of reason, is without God; - let God therefore be in all thy thoughts.

$$
(H P, \text { p. 42) }
$$


All are God's family; he knoweth every one of them, as a shepherd knoweth his flock: they pray to him in different languages, but he understandeth them all; he heareth them all; he taketh care of all; none are so great that he cannot punish them; none are so mean that he will not protect them.

$$
\text { (HP, pp. 59-60) }
$$

\section{(iii) Enabling Children}

The achievement of Hymns in Prose, then, is that it diminishes the palpable threat which children hold over adults in Lessons for Children. When the child's voice can ask questions to which there is no immediately logical earthly explanation, secular adult authority is rattled by its inherent reflexiveness. The adult does not know the answers to the questions asked of it, and its solution - to maintain its own integrity - is to dominate the child with orders rather than reason with it through dialogue. The child is resultantly shut out, precisely because it is such an imminent danger to the adult self. However, when adult authority is subsumed by the authority of God, this threat no longer occurs because the adult's role in listening to a child's difficult questions is - at its most complex - to act as a mediator between them and

God. Hymns in Prose, by implication, enables children to question, whereas Lessons for Children merely seeks to instruct them. The difference between these two positions is profound.

So, God seems to have been ejected from Lessons for Children because of what we may speculate to be the problems of imaginative scope that his attendance would have engendered in it. Ironically, through, his presence in Hymns in Prose actually resolves the imaginative problems that turned out to exist in Lessons for Children anyway. Hymns in Prose certainly provides a more effective rebuttal of Johnson and Lamb than its predecessors, precisely because it enables rather than denies youthful imagination. Instead of rejecting imagination for didacticism, Barbauld's later text grasps the nettle with which her earlier text seems so unwilling to engage. In doing this, she promotes her educative schema - that of Dissenting Presbyterianism - far better than she did earlier when she exorcized God from its framework. 
Also, she confirms her double dissension, both theologically and literarily, as the genrestraddler with whose work neither Johnson nor Lamb felt at home: she can be seen, in terms of her writing for children, as both an Augustan and a Romantic, or, just as convincingly, as neither. As an anonymous critic in The Hibbert Journal puts it, '[Barbauld] believed that children should be happy. ${ }^{, 66}$ Happiness, it seems, is to be found where God, children, and literature meet in constructive and enabling dialogue.

${ }^{66}$ Anon., 'A Forgotten Children's Book,' The Hibbert Journal, 63 (1964-5), 27-34 (p. 32). 


\section{CHAPTER FIVE}

SARAH TRIMMER: THE GUARDIAN OF EDUCATION 
The recent co-publication by Thoemmes Press and Edition Synapse of the first modern edition of Sarah Trimmer's The Guardian of Education has done a great service to those who would research the history of children's literature. In its initial form, The Guardian was a periodical designed to monitor the content of early English writing for children whilst simultaneously theorising methods for its improvement. The Guardian was originally distributed from 1802 to 1806 , during which period it gathered together for the first time a substantial number and range of named English children's books, from instruction manuals through to fairy tales. It became, quite literally, the critical culmination of the educational and children's literary work that filled Trimmer's life; she died in 1810 , only a few years after the publication of The Guardian's final issue. Even now, the unique depth and breadth of The Guardian's content stands as a testament to both the individuality and the importance of its remarkable writer. It is, in itself, reason enough to pay attention to Sarah Trimmer. In spite of this, though, The Guardian will not be this chapter's primary textual focus, but will rather provide an essential backdrop to it. The book which is to be investigated here in the light of The Guardian is Sarah Trimmer's most famous work for children: Fabulous Histories (1786).

For a book which was produced alongside the major children's literature of Day and Barbauld, it is interesting that Fabulous Histories unites into one the foremost concerns of these two immediate contemporaries. It participates in Sandford and Merton's battle between representatives of sense and sensibility, and it shares Barbauld's anxiety about the ways in which books should go about enabling the imaginations of their child readers. Fabulous Histories should be considered against this background as a text that touches upon the monstrous possibilities of both these discourses on its way to demonstrating the benefits of a humane lifestyle. These alienating prospects are exacerbated, according to a problematic essay by Moira Ferguson, by Trimmer's supposed flirtation in Fabulous Histories with class 
and racial tensions, although these - as shall be seen - do not operate in quite the manner that

Ferguson suggests. In brief, Fabulous Histories is every bit a documentation of difference.

Its purpose is to show that wicked, bad, and unacceptable divergences can arise wherever education is insufficiently guarded.

\section{(i) The Guardian of Education: The Parent of Parenting}

The most obvious point to be gleaned from Trimmer's decision at the beginning of the nineteenth-century to publish a serious periodical entitled The Guardian of Education is that she felt that her time required someone to act as guardian to its educational principles. She also thought that she, with her monarchist Anglican standards to support her, was suitably equipped to perform this task. To this end, The Guardian homes in on children's literature as its period's most important educative tool, and reduces the vast scope of work which could potentially be discussed under such a remit to a smaller body which could be manageably and coherently criticized:

Trimmer... set clear rules as to what she would and would not review [in The Guardian], and by doing so she... broke new ground in defining children's literature. She did not consider foreign-language publications for review (5:94), and by and large... she did not review her own work... Her decision to exclude broadsheets from her reckoning, that is to say single-sided publications often printed with ballads or comic songs and stories, had more far-reaching implications $(3: 208)$. Trimmer was specifying what should and what should not, with propriety be considered children's literature. She was unequivocal, for instance, that "Novels certainly, however abridged, and however excellent, should not be read by young readers." $(2: 29)^{67}$

There is a lot of clear-cut sense in these editorial choices. Trimmer's decision to review only

English children's literature is logical, firstly because her mother tongue was English, and secondly because including works in other languages would have made impossible her

\footnotetext{
${ }^{67}$ Matthew Grenby, 'Introduction,' in Sarah Trimmer, The Guardian of Education: A Periodical Work, intro. Matthew Grenby, 5 vols (Bristol / Tokyo: Thoemmes Press / Edition Synapse, 2002), hereafter $G E$, I, v-xli, hereafter $M G$ (pp. xv-xvi).
} 
already substantial supervisory commitment. ${ }^{68}$ Likewise, her resolution to discard broadsheet publications is also understandable because they were then being produced at too rapid a rate to make a considered inclusion of them realistic. Indeed, some of Trimmer's greatest concerns for her society form around this latent uncontrollableness of production and the sheer volume of unchecked children's material that was fast becoming available. There was, for her, simply too much inappropriate material flooding the contemporary market:

Formerly children's reading, whether for instruction or amusement, was confined to a very small number of volumes; of late years they have multiplied to an astonishing and alarming degree, and much mischief lies hid in many of them. The utmost circumspection is therefore requisite in making a proper selection, and children should not be permitted to make their own choice, or to read any books that may accidentally be thrown in their way, or offered to their perusal; but should be taught to consider it as a duty, to consult their parents in this momentous concern.

(GE, II, p. 407)

For Trimmer, then, the idea that children should read is imperative but the momentous choice of what they should read is more their parents' concern than it is their own. Notably, Trimmer is not trying to set herself up in isolation as education's guardian. Instead, she is attempting to inculcate her principles of guardianship into the minds of her journal's adult parent readership.

Amongst all of these editorial decisions and explanations, though, the most important and the most misinterpreted is that in which Trimmer rails against the prospect of children reading novels: 'novels certainly, however abridged, and however excellent, should not be read by young readers.' No matter the quality of novel, Trimmer says - allowing, importantly, that novels can be excellent - children should not read them. This statement is taken by some of Trimmer's critics as an emblem of her aversion towards all works of

\footnotetext{
${ }^{68}$ By way of parenthesis, it should be pointed out that The Guardian does include commentaries on English translations of certain foreign-language stories, e.g., Mme de Genlis' Adelaide and Theodore.
} 
literary imaginativeness, especially, as Matthew Grenby points out, when viewed in tandem

with her attitude towards fairy tales:

[Trimmer's] notorious hostility to fairy tales, the literary form which has generally been seen as the most important influence on children's literature in the early nineteenth century, only confirms this characterization, apparently establishing Trimmer as the enemy of imagination. And so it is that critics have been content to view Trimmer as the representative of all that was retrograde in the late eighteenth and early nineteenth centuries, whether in the political, religious or literary sphere.

$$
(M G, \text { p. xxii) }
$$

This representation of Trimmer as one who is anti-imagination, is, as Grenby's derisory tone implies, just not correct. It is certainly fair to say that she blasts fairy tales as a reading medium that it is inappropriate to give to children, but her attack arises out of problems far more fundamental than any fairy tale's potential to enable youthful fancifulness:

In Blue Beard, for instance, the second plate represents the opening of the forbidden closet, in which appears, not what the story describes, (which surely is terrific enough!) " a floor clotted with blood, in which the bodies of several women were lying (the wives whom Blue Beard had married and murdered,") but, the flames of Hell with devils in frightful shapes, threatening the unhappy lady who had given way to her curiosity! The concluding print is, Blue Beard holding his terrified wife by the hair, and lifting up his sabre to cut off her head.

$$
(G E, \mathrm{IV}, \mathrm{pp} .74-5)
$$

Trimmer here is not rejecting Blue Beard for its imaginative scope but because, in her view, it is simply too gory and contains too many mutilated women for children to cope with. Even in the liberal twenty first-century west, one wonders how many parents would be willing to supply material to their children which could be summarized in terms such as these. Denying children access to stories like Blue Beard can arguably be called an act of conservative censorship, but it can hardly be termed imaginatively retrograde. Indeed, at heart, it encapsulates a crucial debate about what is and what is not appropriate for children that is still very much alive today. 
Trimmer, then, is categorically not imagination's enemy, but it is true enough that there are aspects of imagination's scope which worry her greatly. In guarding education, she is, after all, implicitly guarding imagination as well. Against this backdrop, Trimmer is, for example, vitriolic in her rejection of Rousseau's Émile. She claims that 'the greatest injury the youth of this nation ever received, was from the introduction of ROUSSEAU's system, given to the world in the history of Emilius, an imaginary pupil, educated upon an entirely new principle; which proposed to banish Christianity from the nursery and the school, to make room for a false PHILOSOPHY, which has no foundation in truth or reason.' ( $G E, \mathrm{I}, \mathrm{p}$. 10) More generally, Rousseau's writing, for Trimmer, is 'a perpetual mixture of truth and error' which is 'visionary, fallacious, and dangerous.' (GE, I, p. 184) Émile, in short, is a bad thing. If used in relation to children, it will give rise in them to bad imagination and bad understanding.

By comparison, Trimmer's good imagination and good understanding are founded essentially upon Christian principles, i.e., the very things which she is so worried to find Rousseau's Jean-Jacques banishing from Émile's nursery. Trimmer's flavour of Christianity, when it is juxtaposed with that of some of her contemporaries (e.g., Mary Martha Sherwood, the subject of this thesis' next chapter), is neither fundamentalist nor Evangelical. Instead it is akin to modern Anglicanism, complete with a relatively liberal approach to such thorny doctrinal issues as the nature of original sin:

Either the child is cleansed from the original corruption of human nature by baptism, or he has received no spiritual grace at all; and if he has been cleansed, can he be considered as still in a state of confusion in consequence of Adam's sin? This would be to destroy at once the efficacy of that Holy Sacrament, in which there is perfect remission of sins and sanctification. And so far from allowing that children are naturally disposed to wickedness, we are fully persuaded, that by the gift of the Holy Ghost bestowed upon them in Baptism, they are disposed to goodness, but the animal nature in children, as we have before observed, gains strength whilst their reason is weak and imperfect, and if left to themselves, passion and appetite will certainly increase.

$$
\text { (GE, II, p. 468) }
$$


In other words, for Trimmer, children become disposed to goodness through baptism, but it is the framework into which they are set after receiving this fundamental sacrament that will determine the eventual outcome of their characters. In support of this tenet, Trimmer rejects traditional conservative religious pedagogy - catechetical rote - by saying that want of spiritual understanding in children is in a great measure to be ascribed to the prevailing method of exercising the memories of children in learning by rote lessons greatly above their capacities, and suffering them to read without reflection, instead of initiating them by such simple instructions as would generally unfold their understandings, and render their minds capable of receiving lasting impressions concerning things of the utmost importance to their present and future happiness. ${ }^{69}$ For Trimmer, education is rather about explanation, assimilation, and comprehension. If the learning subject cannot participate in and fully understand what it is being taught then, in Trimmer's terms, the lesson is not being taught successfully, and, if the lesson is not being taught successfully, then a fertile base for good and sensible imagination will not be rightly established.

Thus, from the evidence of The Guardian, Trimmer's view of her topic may be summarized by stating that in opting to become a writer for children one commits oneself to the production of material which will nourish the minds of children in (broadly) a Christian context. Likewise, in opting to become a parent, one commits oneself to the careful monitoring of the material which contributes to one's child's mental nourishment. These two semi-related agenda define The Guardian's content, in which Trimmer sets up herself as the guardian of education and the parent of parenting. They are the essence of her work and they are what she was about. They provide, in all their arguable arrogance and with all their undeniable achievements, a conceptual foundation upon which well-founded analyses of her work must be based.

\footnotetext{
${ }^{69}$ Sarah Trimmer, Reflections Upon the Education of Children in Charity Schools (London: [printed for] T. Longman, J. \& F. Rivington, 1792), p. 34.
} 
From the title of Trimmer's very first publication for children - An Easy Introduction to the Knowledge of Nature, and Reading the Holy Scriptures, Adapted to the Capacities of Children - it is clear that the juxtaposition of nature with theology is as important to her as it was to Barbauld. $^{70}$ Indeed, one might even say that they are inseparable, since the significance of their concurrence continues into the shaping of the advertisement which opens Trimmer's most famous children's work, Fabulous Histories:

It certainly comes within the compass of Christian Benevolence, to shew compassion to the Animal Creation; and a good mind naturally inclines to do so. But as, through an erroneous education, or bad example, many children contract habits of tormenting inferior creatures, before they are conscious of giving them pain; or fall into the contrary fault of immoderate tenderness to them; it is hoped that an attempt to point out the line of conduct, which ought to regulate the actions of human beings, towards those over whom the SUPREME GOVERNOR hath given them dominion, will not be thought a useless undertaking. ${ }^{71}$

From this, Trimmer's primary concern for her book seems to be that it should imaginatively teach Christian knowledge to govern children's physical and emotional responses to nature, and that these responses should constitute a notional midpoint between the negativities of giving torment on the one hand and being immoderately tender on the other. It is this midpoint, this line of conduct, which delineates - in Trimmer's terms - what it is to be human, and deviations from it can arise either from poor education or from bad example. Successful parents are defined by their ability to mediate between God and their children in order to facilitate their children's discernment of this right path of moderate tenderness and subsequently start their journey along it.

\footnotetext{
${ }^{70}$ Grenby goes so far as to suggest that the 1780 publication of An Easy Introduction was 'probably... motivated by the appearance of Anna Laetitia Barbauld's Lessons for Children, the first part of which had been published in 1778.' ( $M G$, p. vii) If this is so, perhaps Trimmer was concerned by the absence of Christianity from Lessons for Children and was looking for ways in which to compensate for it.

${ }^{71}$ Sarah Trimmer, Fabulous Histories: Designed for the Instruction of Children; Respecting Their Treatment of Animals (London: [printed for] J. Longman, et al., 1786), hereafter $F H$, p. vii.
} 
This clear and basic manifesto is made more complicated, however, by Trimmer's explanation of the way in which she proposes to effect its promotion in Fabulous Histories.

This is a book, the reader is told:

In which the sentiments and affections of a good Father and Mother, and a family of children, are supposed to be possessed by a Nest of Redbreasts; and others of the feathered race are, by the force of imagination, endued with the same faculties: but, before [children begin] to read these Histories, they [should be] taught to consider them, not as containing the real conversation of Birds, (for that it is impossible we should ever understand,) but as a series of FABLES, intended to convey moral instructions applicable to themselves, at the same time that they excite compassion and tenderness for those interesting and delightful creatures, on which such wanton cruelties are frequently inflicted, and recommend universal Benevolence.

(FH, pp. x-xi)

The content of this syntactic marathon is more than a little confusing. It states that those who use Fabulous Histories should suspend their disbelief whilst reading it because birds are represented in it as having a human sentience and ability to converse which it is impossible that they could possess in real life. Nevertheless, the real life lessons contained in Fabulous Histories implicitly rely upon the compassion and tenderness which arise from the existence of this avian sentience and conversation - the very things which it has just been pointed out are not possible in reality. Like is not being compared with like here, as the implied child audience is asked to believe literally and yet not literally in Fabulous Histories' contents. In this instance, Trimmer is pointedly enabling young imaginations in a way that Barbauld particularly in Lessons for Children (thinking, for example, of Puss' problematic inability to speak) - could not countenance. She is using selective and signalled misinformation to impart essential lessons in a way which resonates distinctly with the terms of Todorov's fantastic. She is creating but crucially controlling a hesitation between the real and the literary for the sake of impacting unhesitatingly on her audience's perception of the real. She 
does not want to conflate the real and the literary ${ }^{72}$ but she does want to suggest that the two can have functional interplay. It is in the way that Trimmer tackles this interplay that the demonstrative power of Fabulous Histories is most effectively realized.

From their prominence in the book's prefatory material, one could be forgiven for thinking that talking animals are going to be the central characters in Fabulous Histories. Indeed, Trimmer later goes on to refer to Mr and Mrs Redbreast - a pair of robins - as 'the Hero and Heroine of my tale.' ( $F H$, p. 220) However, in spite of the claimed importance and the frequency of their presence, the speaking creatures in Fabulous Histories are actually little more than functional. True, the Redbreasts provide an avian analogy to the story's human family, the Bensons, in whose orchard the Redbreasts live. They also work hard to demonstrate to their offspring the logic behind Trimmer-endorsed educational principles, such as remaining obedient to one's parents. However, beyond these points and their occasional interjections into the life of the Bensons, the history of the robins is by-and-large unremarkable. $^{73}$ At the beginning of Fabulous Histories, the Redbreasts establish their nest in the security of the Bensons' orchard. They then hatch their four children - Robin, Dicky, Flapsy, and Pecksy - and the subsequent development of these little ones thereafter dominates the movement of the Redbreasts' narrative. Naturally, the narrator points out carefully that the names given to the four young robins are not their real names because robins do not actually have real names. They are names which are to be used in Fabulous Histories merely 'for the sake of distinction.' (FH, p. 4) Of the four children, Pecksy alone

\footnotetext{
${ }^{72}$ The narrator of Fabulous Histories is pointedly mindful of the transition between the imaginative reality in which birds can speak and the human reality in which they cannot. The shifts between these two are usually made very obviously at the end of chapters, ensuring that their respective worlds are kept clearly separate and denying them the opportunity to blend into one another.

${ }_{73}$ In 1818 and 1819, respectively, the phrase The History of the Robins was incorporated as a subtitle and then a full alternative title to abridged editions of Fabulous Histories. By all accounts, and perhaps because the Redbreasts' history is neither overly exciting nor her story's central focus, Trimmer always preferred the title under which she had originally released her book. This explains why Fabulous Histories was never given any other published name during Trimmer's lifetime. (See Donelle Rowe, 'Guarding the British Bible from Rousseau: Sarah Trimmer, William Godwin, and the Pedagogical Periodical,' Children's Literature, 29 (2001), 1-17)
} 
grows up to become the robin equivalent of a model citizen: 'all the little Redbreasts, excepting Pecksy, in turn committed some fault or other, for which they were occasionally punished; but she was of so amiable a disposition, that it was her constant study to act with propriety and avoid giving offence.' (FH, p. 25) Pecksy achieves this ideal state by being a 'happy medium betwixt self-conceit and timidity:' (FH, p. 95) she knows that she is able but she is willing in all things to cede to the wisdom and guidance of her parents. Dicky and Flapsy, by comparison, are more vacuous characters, who are too self-conceited and too timorous to have any substantial worth in Fabulous Histories. Their giddiness and minor greed eventually lead to them being captured and incarcerated in an aviary, in which they are required to learn humility and to become contented with their lot. Finally, the last little Redbreast, Robin, is too quick tempered and thinks too much of himself for being the nest's first-hatched son to be wholly satisfactory. He pays consistently for both these faults by being frequently ostracized from the loving bosom of his family. On the most telling of these occasions, Robin, having failed to accept his father's advice on the subject of flying, suffers a fall which injures one of his wings. He undergoes a (by this time in the narrative typical) period of solitude and becomes genuinely contrite for his pride and stubbornness, but the damage to his wing turns out to be permanent. He is obliged to confine the rest of his days to the orchard in which he was brought up. He, like Dicky and Flapsy, becomes subject to an imprisoned existence; an existence limited by the results of immoderation.

Already the discourse of sense and sensibility that was so prevalent in Sandford and Merton can be seen to hold sway Fabulous Histories. Mr and Mrs Redbreast are represented as bastions of sense and the character success of their children is measured by the children's success (or not) in emulating their parents. Pecksy is shown to be sensible by her consistent display of courage and humility, whereas Robin, Dicky, and Flapsy all give way to their sensibilities and are resultantly penalized. Such, in Fabulous Histories, are the stories of the 
Redbreasts. They tend towards the cautionary but resolve fundamentally into contentment. Although Robin, Dicky, and Flapsy all finish the book suffering the consequences of their respective weaknesses, they are nevertheless represented as being as happy as their concluding circumstances will permit them to be. The narrative punishes them for their sins but their sentences are far from being absolutely abjecting. This is because, to reiterate, the Redbreasts are not the direct focus of Trimmer's story. Instead, true to the book's introductory material, their presence is intended simply to advance the proposition that animals might relate to one another with a depth and complexity comparable to that which defines human interactions. In fulfilling this function, the Redbreasts raise their audience's perception of the value of animal life. In the Redbreasts' presence, animals cannot be viewed as dull and unsophisticated beasts over which humans have controlling dominion. Rather, from the Redbreasts' clear and simple analogy to a nuclear human family, animals must become regarded as advanced creatures over which humans have the responsibility of careful stewardship. The existence of the Redbreasts, therefore, tangentially reinforces the purpose of Fabulous Histories: to demonstrate to humanity, personified in the Bensons, that animals require respectful treatment, and that those who do not accord to this requirement should be regarded - in the most negative sense of the word - as monsters (because of their immoderation). To this end, the specific familial developments of the Redbreasts need only be of secondary interest because the implications of these developments pale by comparison to the wider implied impact of the simple fact that the robins are present. Robin, Dicky and Flapsy need not be punished any more than they are for their misdemeanours because none of them is a significant enough character in the text to warrant it. There are, in Fabulous Histories, characters who are contextually guilty of far more monstrous crimes than the small divergences exhibited by these three little robins. 
To find these characters, we need to move away a little from Fabulous Histories' talking creatures and to give time instead to their human counterparts. Let us consider first the Benson family. The evolutions and characterizations of the young Bensons are pointedly similar to those of the juvenile Redbreasts, and this serves the narrative function of reinforcing the inter-species parallelism between the young birds and the human children. Even though the young Redbreasts are more minor characters in Fabulous Histories than the young Bensons, there is still potential for the reader to learn lessons from both communities. Harriet, aged 11, compares directly with Pecksy as the embodiment of youthful virtue in the Benson establishment. She is kind, intelligent, rarely in need of chastisement, and - allimportantly - attentive to the wills and the advice of her parents. Frederick, aged 6, is more temperamental, and is still, as the story unfolds, very much on the learning curve of young childhood. Like Harriet, he is good natured and benevolent, but he remains in greater need than her of parental guidance and regulation. This is made clear at the very beginning of Fabulous Histories, when Frederick declares - after having fed the Redbreasts for the first time - that he should like to spend all his money on taking care of birds. 'Hold, my love, said Mrs. Benson, though I commend your humanity, I must remind again, that there are poor people as well as poor birds.' (FH, pp. 7-8) Thus, Frederick's wishes are seen to do him credit, but their youthful impulsiveness is tempered to ensure that they are directed and ordered in a prioritized fashion. He needs to move his generosity beyond the Redbreast family, to which the reader of Fabulous Histories is being so deliberately attracted, and apply with a broader philanthropy the lessons which he has learnt with respect to the robins.

Having been thus established, the relationship between the Bensons and the Redbreasts subsequently builds up around the Redbreasts' regular applications for sustenance at the Bensons' (especially during the period when the four little Redbreasts are still confined to the nest and their family is therefore particularly needy). Harriet and Frederick form quite a 
rapport with their small visitors and there develops an implied co-evolution between the two families as the book proceeds. Like the young robins, the two Benson children go through a number of set-piece developmental events and lessons, the most obvious and longest narrative example of which comes during their visit to the family of Farmer Wilson in the latter stages of Fabulous Histories. On Wilson's farm, Harriet and Frederick are introduced to a plethora of animals, and are given opportunities to apply the knowledge which they have learnt throughout the book to this wider range of animal creation. At the same time, Mrs Benson and Mrs Wilson simultaneously reinforce the need for humanity to act responsibly and empathetically with those creatures over which it has stewardship:

I am of the opinion, said Mrs. Benson, that it would be a good way to accustom one's self, before one kills any thing, to change situations with it in imagination...

Indeed, Madam, said Mrs. Wilson, I have often wished that poor dumb creatures had somebody to speak for them; many an innocent life would then be saved, which is now destroyed to no end.

(FH, pp. 159-60)

Here again, as in Trimmer's introduction to her book, the deliberate privileging of imagination is meant to prevent any tendency in the reader to dismiss animals - or, indeed, in Mrs Wilson's terms, anything with which one cannot communicate directly - as necessarily subordinate. Mrs Benson and Mrs Wilson give thought to the unthought of and voices to the voiceless: they knowingly suggest impossible role reversals between humans and animals for the sake of educational benefit. They use animals, filtered through imagination and reinforced in Fabulous Histories by the confessedly fantastical voices of the Redbreasts, as demonstrative tools to inculcate the principles of Christian benevolence in both their textual and their reading audiences. Theirs is a striking double act, which breaks down the class differences between their two families by demonstrating that even those from divergent social backgrounds can show identical levels of understanding about certain imperative issues, e.g., the importance of acting with humanity towards all members of God's creation. 
In essence, and judging by the evidence of The Guardian, they behave much like one would expect Trimmer (to want) to behave.

As representatives of sense in the discourse of sense versus sensibility, however, the demonstrative mutual power of Mrs Benson and Mrs Wilson is only limited. Neither of them is, in the strongest senses of the word, a monster, because neither of them wields the full revealing clout of monstrosity's latent unacceptability. Nevertheless, Fabulous Histories' introduction has already provided a contextual location in which this sort of intolerable monstrosity can be looked for, by making deplorable those whose sensibilities lead them to treat animals with either excessive cruelty or excessive deference. Where can such characters, who are prepared to violate the lessons laid down both by the speaking Redbreasts and by the sensible Bensons, be found in this text?

The first of them can be found in Edward Jenkins, the son of a local family, who, with his sister Lucy, comes to visit the Benson's in Fabulous Histories' eighth chapter. Master Jenkins is the same age as Miss Benson but this is the only characteristic that the two share. Where Harriet is civil, Edward is brutish. Where she is respectful, he is discourteous. Where she is kind, he is cruel. The narrative's reservations about Edward are instigated by his avowed desire to harm birds, the very animals that are given prominence above all others in Fabulous Histories. He steals nests, blows out their eggs, and then threads the shells together for Lucy to keep. (FH, p. 56-7) This, though, is only the tip of Edward's immoral iceberg. He throws kittens off roofs, plucks feathers out of live chickens, and drowns a litter of puppies in the sight of and against the protestations of their mother. (FH, pp. 62-3) He, in terms of Fabulous Histories, is the foulest of monsters.

To make matters worse, Edward's behaviour is explicitly endorsed by his father. When Mrs Benson attempts to remonstrate with Mr Jenkins on the subject of his son's conduct, 'this gentleman, so far from reproving his son, applauded him as a lad of life and spirit, and 
said he would be fit to go through the world.' (FH, p. 65) The irony of crediting a child who drowns puppies as 'a lad of life' is far from lost on Trimmer's narrative, as Mr Jenkins unwittingly validates the claim that the badness of children stems from the badness of their parents. Mr Jenkins, certainly, is no adequate guardian of education, and he is therefore - in Trimmer's terms - a total failure as a father. The world through which he claims that Edward is fit to go is not one that Trimmer is prepared to tolerate. With poetic justice, the little boy dies at the story's conclusion when he is thrown by a horse that he has persistently mistreated. (FH, p. 220)

Edward's opposite number - the character who maltreats animals through exorbitant fondness rather than neglect - is Mrs Addis, a lady on whom Mrs Benson and Harriet pay a visit at the midpoint of Fabulous Histories. Mrs Addis, like the Jenkins and the Bensons, has two children, Augusta (7) and Charles (12), although, from her behaviour, one would hardly know it. Mrs Addis' house is a menagerie in which all attention is given over to its faunal occupants. Augusta is seen briefly in the drawing room into which Mrs Benson and Harriet are received by Mrs Addis, but the little girl is so unkempt, awkward and (ironically) bestial, that she is swiftly dismissed. (FH, pp. 103-5) By comparison, Mrs Addis' animals are indulged utterly, particularly her monkey, who, having broken his restraining chain, is greeted by his owner with the words:

O my dear sweet pug... are you come to see us? Pray shew us how like a gentleman you can behave; just as she had said this, he leaped upon the tea-table, and took cup after cup, and threw them on the ground, till he broke half the set; then jumped on the back of his mistress's chair, and tore the cover of it; in short, as soon as he had finished one piece of mischief, he began another; till Mrs. Addis, though vastly diverted with his wit, was obliged to have him caught and confined.

$(F H$, p. 105)

Mrs Addis' vulgarity is clear for all to see and her unchecked amiability with animals is as degenerate as Edward's physical cruelties are diabolic. As Mrs Benson sagely observes to 
Harriet, 'Mrs Addis... has absolutely transferred the affection she ought to feel for her child, to creatures who would really be much happier without it.' ( $F H$, p. 107) Intolerable dissoluteness results from this transference, exhibited first when Mrs Addis forgets to treat her guests with the appointed social niceties when her parrot falls ill, (FH, pp. 108-10) and second when the Bensons later discover that Mrs Addis has abandoned poor people who live close to her in favour of maintaining her animals in the lap of the luxury. $(F H$, p. 111) Not only, therefore, does Mrs Addis' skewed outlook on life unbalance her and her children with respect to the created order (Charles grows up to be an animal-hater and Augusta an animalfearer $(F H$, p. 224)) but it also makes her forego her most basic duty of Christian charity. To be fair, she does eventually realize the monstrosity of her existence but far too late for her to do anything about it. By the end of Fabulous Histories, her children - not unreasonably - no longer wish to know her, and it is her final lot to suffer an ignominious descent into lonely old age. $(F H$, p. 222)

To summarize, Master Jenkins and Mrs Addis are both monsters, inasmuch as they demonstrate approaches to life which are, contextually, utterly unacceptable. In fact, they are made doubly dangerous in Fabulous Histories because the blinkeredness of their respective conditions arises from their incorrect imaginative engagement with animals: they provide divergent examples of the very sensibilities against which Trimmer's text sets itself in opposition. Edward, at one extreme, has no imaginative engagement with animals: he, in every possible sense, is unable to hear the conversation of the robins. For him, animals are objects to be exploited, without feelings or emotions that should in any way mitigate his behaviour towards them. According to his father, Edward's demonstrable inhumanity towards animals serves to make him more of a man. According to Trimmer's narrative, it does not. It serves instead to make him more alien, more reprehensible, less benevolent, and less human. Mrs Addis, by comparison, has an imaginative engagement with animals which 
blinds by its absoluteness. She sees such life, such personality, and such joy in animals that she cannot countenance anything other than their complete indulgence. From this stance, she becomes not only an appalling mother to her children, but also an unfit steward of the animal creation. Hers is an undisciplined and ultimately selfish vantage point, which is derived from an excessively heightened imagination and a complete lack of common sense.

Calculatedly, and in spite of their delivery in a children's book, neither of these two attacks is meant to provide lessons for children alone. True, Edward Jenkins' malice is as reprehensible as Augusta Addis' wildness is socially intolerable, but these crises are not wholly of the children themselves. As was the case with Day's Tommy Merton, Edward and Augusta's problems stem from their parenting, and Trimmer's voice, as the self-appointed guardian of education, speaks to adults in the chastisement of the children's respective flaws. By representing wickedness and calamity in child characters, who presumably began their lives as innocents but have since fallen into corruption, the narrative of Fabulous Histories apportions blame to those who have failed to bring up their children better. In a story in which the real heroine and hero, Harriet and Frederick, are models of virtue and goodness, those who fall short of their example confront the reader with stern queries about the origins of character defects. These origins, it is implied, are found in a lack of interactive parenting and a paucity of imaginative training. In manifold senses, shoddy parents - unguarded educations - produce little monsters, as surely as immoderation leads to pointed earthly punishment.

Clearly, then, Fabulous Histories can be readily identified as a documentation of difference. Correctness in it is established by and associated with the Bensons, the Wilsons, and to a lesser degree the Redbreasts, and divergence from the pathways that they advocate (which is seen, for example, in the Jenkins and the Addis) is intolerable. Leading from this framework, it is notable that Moira Ferguson, in her 'Sarah Trimmer's Warring Worlds,' 
identifies an alternate locus of deviance in Fabulous Histories in Trimmer's supposed advocacy in her book of class and racial prejudices. There are two particular events that Ferguson homes in on to illustrate this contention, which are Mr Redbreast's admonishment of Dicky for his weak-hearted lack of willingness to fly, and a collective attack by a number of birds on a passing cuckoo:

Dicky began to think that it was in his interest to obey his father, and said he would endeavour to fly up [to the nest], but was still fearful that he should not be able to effect it. Never despair, replied his father, of doing what others have done before you. Turn your eyes upwards, and behold what numbers of birds are at this instant soaring in the air. They were once all nestlings like yourself. See there the new fledged Wren, with what courage he skims along; let it not be said, that a Redbreast lies grovelling in the earth, whilst a Wren soars above him!

(FH, pp. 92-3)

So saying, [Mr Redbreast] flew on, and they soon saw a Cuckow, surrounded by a number of birds, who had been pecking at her till she had scarce a feather left upon her breast, whilst she kept repeating her own dull note, Cuckow! Cuckow! incessantly. Get back again to your own country, said a Thrush; what business have you in ours, sucking the eggs, and taking the nests of any bird you meet with? Surely it would be sufficient, could you have the privilege of building for yourself, as we do who are natives; but you have no right to seize upon our labours, and devour our offspring. The Cuckow deserves his fate, said the hen Redbreast. Though I am far from bearing enmity to foreign birds in general, I detest such characters as his. I wonder mankind do not drive Cuckows away, but I suppose, it is on account of their being the harbingers of summer.

(FH, pp. 138-9)

As instances of the sort of tensions that Ferguson is attempting to discuss, neither of these incidents is actually very persuasive. To suggest, in the first example, that Mr Redbreast's use of the soaring Wren to inspire Dicky is meant to do anything other than typify constructive parental chivvying seems to be an over-reading, given its context in a book in which as many species of animals and races of birds are noted for their intelligence and excellence as they are for their faults. Admittedly, the cuckoo incident is a bit more troubling, since its talk of countries and nativeness pushes the impression that it depicts a xenophobic attack on an outsider. This understanding as well, though, must be moderated 
with the realization that the cuckoo is one of the closest natural analogies to a bird parasite: cuckoos do, after all, quite literally destroy the families of those birds into the nests of which they lay their eggs. Maybe Ferguson is right to read this as a racist attack against outsiders, but, given that the cuckoo is its only named target and that the cuckoo does not clearly represent a specific human group or context, this interpretation does not really allow this scene to achieve anything. It appears more likely that this is just another vehicle - amidst a sequence of many others - to show that the world contains many characters who are lazy and exploitative and who will quite happily, if permitted, live for nothing off the hard work of others. This is not a comment on race. It is a comment on temperament and being temperamental.

Ferguson's choice of examples with which to illustrate her contention thus looks to be a little skewed, but this is not to say that the gist of her point and the strains embodied in it should be dismissed as invalid. Indeed, one of the little Redbreasts' most important lessons is learnt when they first encounter humans and are overwhelmed by the racial (specific) differences between them. In the sixth chapter of Fabulous Histories, Mrs Redbreast returns to her nest to find her children in a state of utter terror. When she enquires what has driven them to this condition, Dicky replies: 'Oh! I do not know... but we have seen such a monster as I never beheld before.' ( $F H$, p. 36) After hearing his children's descriptions of a hugeeyed, vast-beaked, and generally horrific entity, Mr Redbreast circles about the vicinity to see if he can identify the monster. His excursion is successful. The monster turns out to be the gardener, Joe, who, having watched the flight paths of the senior robins, decided to inspect their nest (without, of course, damaging it or its contents). However, Mr Redbreast's later assurances of Joe's friendliness do little to pacify his brood, who dread the prospect of seeing such a creature again until after Joe has brought the two little Bensons to view the nest as well. After receiving this empirical evidence that humans can be benign in spite of their 
shocking size and physiognomy, the little robins are eventually placated, particularly when they are supplied with the knowledge that the Bensons have on numerous occasions acted as benefactors to their family. Clearly, the dismissal of creatures purely on the basis of the outward structure - the physical signs of their race or species - is not satisfactory. Humans, it seems, need not be as bad as they might initially look.

The problem is, of course, from the evidence of Mrs Addis and Master Jenkins, that some humans can be just as bad as they initially look if circumstances dictate them to be so. $\mathrm{Mr}$ Redbreast, it turns out, lost an earlier nest to the evil of human bird thieves, upon discovery of which his previous mate died from grief. (FH, pp. 50-4) Immediately after Fabulous Histories relays this tragic story, its enormity is hammered home by Edward's detailed description of his own nest-snatching exploits. (FH, pp. 56-7) A subtle blend between the world of the robins and the world of the humans consequently occurs, adding magnitude through imaginative interplay - to the badness of Edward's deeds. Although there is no explicit suggestion that Edward was the crook who stole Mr Redbreast's previous nest, $\mathrm{Mr}$ Redbreast's tale nevertheless adds an extra emotional dimension to the iniquity of Edward's actions. In doing so, it makes the boy even more manifestly repulsive. When the Redbreasts later see first-hand evidence of nest-snatching, the boys who are involved are referred to conspicuously as 'little monsters.' (FH, p. 188) These boys are just like Edward and they remind us of him. They remind us that some humans can be just as bad as they initially look.

\section{(iii) Fabulous Histories: The Demonstration of Humanity}

Thus, in Fabulous Histories, monstrosity exists in multiple forms. First, there are the parents of the Benson and Redbreast families, whose function is to provide demonstrative mediation and guidance to their children so that their little ones may grow up into wisdom and benevolence. Secondly, there are the Benson and Redbreast children, who variously fall 
away from or maintain their parents' moral statures, and, in doing so, step further away from or move closer to Fabulous Histories' prescribed method of child growth. Finally, and strongest of all, there are Mrs Addis and Edward Jenkins, who embody monstrosity at its most potent and at its most revealing. They are characters who disgust, who appal, and who are so unacceptably different to the standards of Fabulous Histories that they resolve into prototypes of how not to live one's life. All these figures have demonstrative functions and all of them are intended to contribute to the education of the reading audience, whether adult or child. Alongside them, Trimmer toys with notions of alienation and difference in, for example, her apparent interest in the specific (or, more accurately, the phylic) variations between humans and birds. These multiple monstrosities all combine to produce a documentation of difference, which is meant to instruct both children and adults not only respecting their treatment of animals but also respecting their treatment of humanity and nature more generally.

At the heart of this programme are the basic philosophies set out in The Guardian, which is why it is so important to consider Fabulous Histories in the context of that larger work. All of the problems, all of the monstrosities, and all of the revelations in Fabulous Histories are about guarding education and being a responsible parent. Children are taught through it by being given both positive and negative behavioural examples, which are then - through Trimmer's guarding narrative - explained to them in order that they may subsequently determine right from wrong (sense from sensibility). This process is made more compelling in Fabulous Histories by the enablement in it of the child's imagination to accept whilst reading it what more conservative writers would regard as an unacceptable manipulation of the truth, i.e., the pathetic fallacy of giving human qualities to birds. This positive interjection into the imagination of the child, which encourages them in the practice of universal benevolence (into which the advertisement's Christian benevolence intriguingly 
morphs), is, for Trimmer, a far better prospect than the child receiving no imaginative training at all. This is, after all, a way in which education's guardian can promote in her audience a greater understanding of animals, humanity, and God.

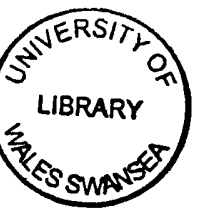




\section{CHAPTER SIX}

MARY MARTHA SHERWOOD: KILLJOY OR JOYFUL KILLER? 
Understanding of the work of Mary Martha Sherwood (née Butt) has been occluded to a uniquely high degree by the myopia of modern criticism. Even when she is situated alongside the difficulties raised by contemporary renderings of, for example, Day and Trimmer, Sherwood remains a writer who is distinctively misread. The reason for this is very simple. Sherwood's biography - characterized, as it is, by evangelical zeal and colonial pedagogy - suggests, correctly, that she was a woman who was both deeply serious and highly committed to her Christian ideals. Indeed, so serious and so committed does she appear that she is often understood to have been a humourless and forbidding woman; one who, as it were, wanted to prescribe life rather than live it. It is from the inferential jump between these demonstrable biographical facts and these debatable biographical extrapolations that misinterpretations of Sherwood arise, because, in spite of her undeniable and serious dedication to religious causes, she was not the killjoy that she is frequently misrepresented to have been. Targeted as she is by post-feminist, post-colonial, and postmodern attacks upon her supposedly uncompromising brand of nationalistic literary educationalism, Sherwood is rather the victim of the temporal and philosophical disjunctures that exist between her and those who now write about her:

What was once so straightforward and logical is now for us embroiling, coercive, and uniformly unsatisfying. Fundamental differences in outlook separating Puritan and Evangelical eras from our own post-Christian, postmodern times afford some reasons for the shift: from a unitary, stable, providential concept of meaning to protean, multiple, and deliberately heterodox hermeneutics; from appeals to order, rank, and authority to daily instances of upheaval, mobility, and interrogation. ${ }^{74}$

Against this background of misapprehension, then, Sherwood's work is ripe for reinterpretation. This process will begin here by briefly examining select events from her biography, which can be used to refute the perception of her domineering sombreness. These

\footnotetext{
${ }^{74}$ Patricia Demers, Heaven Upon Earth: The Form of Moral and Religious Children's Literature, to 1850 (Knoxville: University of Tennessee Press, 1993), p. 2.
} 
will provide a context from which we may consider - and, where necessary, revitalize analyses of her most noted work for children, The History of the Fairchild Family. In this text can be found evidence to support the proposition that Sherwood is indeed a very serious authoress but also one who writes with a fervent - even gratuitous - enjoyment. She is, in fact, an authorial dichotomy, who can blend these apparently disparate elements into a coherent whole. She embodies opposites in one. She is, in her paradoxical duality, an archetypal authorial monster.

\section{(i) Subtle Delights: The Life of Mrs Sherwood}

Born on $6^{\text {th }}$ May 1775, the second child and eldest daughter of George and Martha Butt, Mary Martha Butt had a far from easy upbringing. She records, to exemplify this, in her autobiography that:

It was the fashion then for children to wear iron collars round the neck, with a backboard strapped over the shoulders: to one of these I was subjected from my sixth to my thirteenth year. It was put on in the morning, and seldom taken off till late in the evening; and I generally did all my lessons standing in stocks, with this stiff collar round my neck. At the same time I had the plainest possible food, such as dry bread and cold milk. I never sat on a chair in my mother's presence. ${ }^{75}$

Things did not get much easier for Mary as she grew older. In 1803, she married her cousin, Henry Sherwood, and, in 1805 , she moved with his regiment - the $53^{\text {rd }}$ - to India, where she spent a significant proportion of the next decade delivering Christian teaching to the children of British soldiers. During this period, she lost two of her own children (to whooping cough and dysentery), and, by all accounts, she grieved for them very deeply. Education of her nation's children became at this time a way for her of consolidating her selfhood and fighting against her ongoing impression that she was just a stranger in a strange land. Within such a

\footnotetext{
${ }^{75}$ Mary Martha Sherwood, The Life of Mrs. Sherwood, (Chiefly Autobiographical) with Extracts from Mr. Sherwood's Journal During His Imprisonment in France and Residence in India, ed. Sophia Kelly (London: Darton \& Co., 1854), hereafter MS, pp. 38-9.
} 
framework, it is straightforward enough to agree with Nandini Bhattacharya that 'India formed [Sherwood] as a writer in most ways. ${ }^{, 76}$ If Sherwood should really be regarded as the hyper-sombre writer that she is so often alleged to have been, then experiences like those that she had in India can have only contributed to the gravity of her output.

This reading, though, only considers one side of Sherwood's life story, and it must be balanced out with the fact that Sherwood's autobiography very rarely represents her as having been a sad woman. Yes, her experiences in India were tough, but they did not break her motivation to continue her positive work as a Christian educator. Similarly, her younger days were demonstrably hard but she nevertheless portrays herself as having been 'a very happy child.' (MS, p. 29) Her parents were disciplinarily strict but they were also openminded in their attitude towards female education, and they keenly encouraged the activity of their daughter's imagination. From the age of six, little Mary enjoyed composing stories, which, before she could write them out for herself, she would dictate to her mother. She and her siblings had only limited access to books in their younger years ("'Robinson Crusoe," two sets of "Fairy Tales," "The Little Female Academy," and "Fsop's Fables" formed the whole of our infant library ${ }^{, 77}(M S$, p. 40)), but, as the little Butts grew, they were offered an increasingly liberal rein to roam freely throughout their father's collection. Indeed, unusually for a girl of this period, Mary was even allowed to sit in on her brother's Latin and Greek lessons, and therefore to grow into intellectual equality with her parents' firstborn son. The senior Butts may well have been stern in some ways, but this evidence suggests that they were far from unenlightened and that their children's lives were far from joyless.

\footnotetext{
${ }^{76}$ Nandini Bhattacharya, 'Maternal Plots, Colonialist Fictions: Colonial Pedagogy in Mary Martha Sherwood's Children's Stories,' Nineteenth-Century Contexts, 23 (2001), 381-415 (p. 392).

77 The specificity of this small collection of books is utterly fascinating. It combines Locke's educationalist privileging of Æsop with Rousseau's of Defoe, and yet it simultaneously values the fairy tales which would have been total anathema to both philosophers. It also posits the intriguing question of why Mary's male brother should be encouraged to read The Little Female Academy (which is presumably the book of this title first published by Sarah Fielding in 1749). Clearly, this was an influential book as far as the young Mary was concerned, since her The Governess went on to become alternately titled as The Little Female Academy after its republication in 1827. One suspects that there is more research to be done on the possibilities presented by these textual interrelations.
} 
The important thing to realize from Sherwood's biography, therefore, is that it is incorrect to accuse her simply of being a humourless and obsessive educationalist pedant. Such responses arise either from the temporal disjuncture of modern critical approaches that refuse to situate Sherwood in the context of her period, or from the misconception that the hardship of Sherwood's life made her youthful joyfulness evaporate into unbendingly solemn adulthood. Certainly she took her life's work very seriously indeed (particularly the Christian aspects of it), but this does not mean that she did so without a smile on her face. For example, recording one of Mrs Butt's memories of her daughter as a child at Lichfield, Sherwood writes that:

[Anna] Seward was there, and [Richard Lovell] Edgeworth, and the elder Dr. Darwin. We [the children] were brought into the room to be looked at, and Dr. Darwin took up my brother... by one leg, exclaiming at the same time, "What a fine animal! What a noble animal!" My brother was then a beautiful child, and no doubt he made no small resistance, on being treated thus philosophically; but he was hardly rescued when $\mathrm{Mr}$. Edgeworth's eye fell on me, and having looked at me for some time, he patted his own forehead, and having paid some compliments to my father on my well-nurtured animal nature, he added, with no great tenderness to his feelings, "But you may depend upon it, Mr. Butt, you may depend upon it she wants it here," and the little taps on his own brow were reiterated. This hint made my poor mother for a while very uneasy.

$(M S$, pp. 21-2)

This description, written in the latter days of Sherwood's life, contains neither the vocabulary nor the phraseology of a joyless or humourless writer. The story of Darwin's exclamations, in tandem with the adverbial description of his treatment of Sherwood's brother, is nothing short of hilarious, and the excessive sobriety of Edgeworth's repetitive assessment of Sherwood's mental faculties is dealt with by her with an understated but clearly discernible wit. This is hardly the voice of an exaggeratedly sombre woman, recalling events from a life which has been warped by adversity. This is the voice of one who loves writing, who loves remembering, and who can still see tremendous subtleties and still derive tremendous delight from the gift of her ongoing existence. 


\section{(ii) The History of the Fairchild Family: A Fearsome Hellfire Tract?}

This is also the voice of the woman, however, who, in 1812, began to work concertedly on a book which the normally mild-mannered Humphrey Carpenter would go on to call a 'fearsome hellfire tract: ${ }^{78}$ The History of the Fairchild Family. Clearly, if any credence at all may be attributed to such a statement - and Carpenter's comment is only one among many comparable others - then there still remains further investigation to be done before this chapter's claim of Sherwood's monstrous textual juxtaposition between seriousness and fun can be resolved satisfactorily. The Fairchild Family, eventually published in London in 1818, tells the story of a Mr and Mrs Fairchild, and their three children, Lucy, Emily, and Henry (who are aged eight, between six and eight, and between five and six, respectively, at the time of the tale's beginning). The three little ones never go to school, because they are taught all their lessons by their parents:

Lucy and Emily learned to read, and to do various kinds of needle-work. Lucy had begun to write, and took great pains with her writing: their mamma also taught them to sing psalms and hymns, and they could sing several very sweetly. Little Henry, too, had a great notion of singing. ${ }^{79}$

All the children's skills are learned from their parents by means of the preferred teaching methodology of nineteenth-century British evangelism, i.e., catechetical rote. Any questions that the children have are answered either directly by Mr and Mrs Fairchild or abstractly by God (via Mr and Mrs Fairchild). The book's narrative structure reflects its preference for this practice, since any difficulties that are raised during the little Fairchilds' growth are typically sorted out by the interpolation of expository stories which are told by one of the senior Fairchilds. These are usually concluded with (often psalmic) hymns or prayers, with

\footnotetext{
${ }^{78}$ Humphrey Carpenter, Secret Gardens: A Study of the Golden Age of Children's Literature (Boston: Houghton Mifflin Company, 1985), hereafter HC, p. 3.

${ }^{79}$ Mary Martha Sherwood, The History of the Fairchild Family; or, the Child's Manual: Being a Collection of Stories Calculated to Shew the Importance of a Religious Education (London: [printed for] J. Hatchard, 1818), hereafter $F F$, p. 1.
} 
the implication that the children will learn by heart the moral messages of the stories that they hear.

The Fairchild Family is not, then, a context in which children are distanced from their adult educators by the sort of theosophical difficulties of explanation that plagued the narrator of Barbauld's Lessons for Children. Instead, it utilizes the educational approach of Day's Mr Barlow, of ensuring that children understand at all times where their actions fit in to life's chains of cause and consequence. Also, to a degree, the Fairchilds' existence smacks of Rousseau's regime for his child subject in Émile, inasmuch as none of the Fairchild family members has much to do with society. However, Sherwood's book inclines more generally to being anti-Emile, since the Fairchild children share not only their own and their parents' company, but also have access to Christianity, books, and the arts as well. Remember, for instance, that Henry - rather controversially - entertains a notion of singing, which would have been regarded at this time as an accomplishment to be sought after by fashionable young ladies not gentlemen. Nevertheless, split as Henry is from the vices of society's fashions, his parents have no problem with him taking on board a nominally fashionable female art. In fact, Henry's development of a stereotypically feminine form of expression suggests that - in spite of the children's gender-segregated education (Mr Fairchild teaches his son and Mrs Fairchild her two daughters) - there is no intrinsic gendering in the manner of their growing up. The children are allowed mutual interplay and are represented as happy and good individuals who participate in what is normally a contented home environment.

Thus far, Sherwood's book does not seem to be a particularly obvious locus of either overshadowing gravity or fearsome hellfire, but it is in Mr and Mrs Fairchild's perception of their offspring that these troublesome features eventually present themselves. Contrary to the image just created of the three children, $\mathrm{Mr}$ and Mrs Fairchild do not regard Lucy, Emily, and Henry as straightforwardly happy and good individuals: 
Soon as we draw our infant breath,

The seeds of sin grow up for death:

Thy Law demands a perfect heart;

But we're defil'd in every part.

Hereby, the albatross of original sin is hung firmly about the necks of the junior Fairchilds in terminology which is reminiscent of the Calvinist doctrine of Total Depravity (and which is therefore radically different to the proposition of post-baptismal cleanliness that is advocated by Trimmer). ${ }^{80}$ Suddenly, the children's present spiritual states and their long-term spiritual prognoses no longer seem quite as promising as they did but a few moments ago. Fortunately for them, Sherwood's narrative implies that knowledge of one's sinfulness can go quite some way towards introducing systems through which inherent wickedness may be counteracted. Although the children are not always aware, therefore, of the magnitude and consequences of their inherited spiritual crimes (which alienate and marginalize them both from God and from their parents), Mr and Mrs Fairchild are ever keeping a watchful eye over them to ensure that they become so:

Mr. and Mrs. Fairchild loved and feared God, and had done so, by the mercy of God, ever since their younger days. They knew that their hearts were very bad, and that they could not be saved by any good thing they could do: on the contrary, that they were by nature fitted only for everlasting punishment: but they believed in the Lord Jesus Christ, and loved him for having died for them...

Mr. and Mrs. Fairchild loved their little children dearly; but they did not wish them to be handsome, rich, or great: all they desired for them was, that they might be children of God, and go to heaven when they died.

$$
\text { (FF, pp. 2-3) }
$$

From the spirit of this opening manifesto - in its expression of the senior Fairchilds' shared theological perspective and their resultant desire for their children's lives - come a number of the more prominent critical complications with which The Fairchild Family is now

\footnotetext{
${ }^{80}$ Kenneth Padley, 'The Theology of Robert South, 1634-1716' (unpublished thesis, University of Oxford, 2004), p. 26.
} 
associated. Even by nineteenth-century standards, this is pretty heavyweight and unforgiving stuff, which focuses upon sinfulness, retribution, and death, much more than it does upon the apparently very slim possibility of a redeemed eternity in heaven. In doing this, the book shuts out its audience of children by segregating them from their divine creator. God, in this context, seems much more determined to reject humanity for its inherent sinfulness than he does to forgive and subsequently to save it. What makes the adult Fairchilds' particular interpretation of this material even more confusing, however, is the fact that, in places, they use it with what seems to be hypocritical inconsistency. We are told, for instance, that 'Mr. and Mrs. Fairchild loved and feared God, and had done so... ever since their younger days,' and yet Mrs Fairchild willingly recounts tales of her youth which portray her as having been an especially naughty child. She used to torment animals, break crockery, and steal from the store-room, and she continued in these lapses in spite of her awareness of their iniquitousness. (FF, pp. 32-3) Admittedly, these transgressions are explained away by the inadequate spiritual education which the young Mrs Fairchild got from her aunts, with whom, as a little girl, she went to live after her mother died. The teaching which Mrs Fairchild received, the narrative states, was insufficient for her to develop a relationship with God that was robust enough to allow her to quell the impious sensibility of her unchecked impulses. However, none of these practices seems to have manifested themselves negatively in Mrs Fairchild's adulthood, and she still claims - in the face of the evidence of her misspent youth - that she is a long term child of God. In fact, the true lesson to be derived from the example of Mrs Fairchild's life must surely be that if one is carefully repentant one can be forgiven one's sins, and that experiences of minor dissolution in youth can culminate to make one a more informed speaker on such subjects as a parent. One might even infer that the troubles of childhood, rather than condemning one to hell, can actually turn into the assets of adulthood. 
Mrs Fairchild, then, embodies a strange double-standard in her mediation between the sinful lives of her children and the perfect life of God. There is a disjuncture in her, which wants her children to be good on the one hand and yet wants to maintain an allusive relationship with her childhood's naughtiness on the other. She aspires to the celestial and yet she is drawn to the earthly, and her children become caught - as little monsters - in the middle of the resultant schism. An even more problematic variation upon this inconsistency's theme, however, occurs in the full implications of the senior Fairchilds' designation of themselves as children of God. This permits the occurrence in them of a messy conflation between parental and divine authorities, between literal and figurative children of God. In one of the formative episodes in The Fairchild Family, for example, Mr Fairchild - the book's principal paternal creator - draws his children's attention to an apple tree in the family's garden. Apples from this tree, the children are told, are not to be touched, but Henry still succumbs to temptation and consumes some of the fruit. In doing so, he falls from grace... and the parallels with the biblical book of Genesis need hardly be laboured any further. Mr Fairchild later becomes aware of this contravention of his instructions, but Henry denies any involvement in the crime. It is only when Mr Fairchild eventually learns the truth from talking to one of the servants that Henry, confronted with incontrovertible evidence against him, falls 'down on his knees before his papa, and confesse[s] his wickedness.' (FF, p. 64) Mr Fairchild's response to this admission is short and sharp:

"Go from my sight, bad boy," said Mr. Fairchild: "if you had told the truth at first, I should have forgiven you; but now I will not forgive you." Then Mr. Fairchild ordered John to take Henry, and lock him up in a little room at the top of the house, where he could not speak to any person... "It is better," [Mr Fairchild] said, "that [Henry] should be punished in this world, whilst he is a little boy, than grow up to be a liar and a thief, and go to hell when he dies."

$$
(F F, \text { pp. 64-5) }
$$


In this way, Henry is ostracized from his family for the period of a day (his sin is uncovered just after breakfast), and he is only later reintegrated with them when his mother comes to see him to ensure that he is duly penitent and that he has truly understood the appalling extent of his misdeed. When she is satisfied on both counts, Henry is taken back downstairs and is presented to his father:

"Henry," said Mr. Fairchild, "you have had a sad day of it; but I did not punish you, my child, because I do not love you, but because I wish to save your soul from hell." Then Mr. Fairchild cut a large piece of bread and butter for Henry, which he was very glad of, for he was very hungry.

There are many moments in the totality of this sequence when the position of $\mathrm{Mr}$ Fairchild becomes disquietingly melded with that of God. First, when Henry falls down on his knees to admit his transgression to his father, the manner in which the child's actions are delivered seems to be out of place: its clearest analogies are either to a sinner asking a priest for absolution or to a private penitent praying to God for forgiveness. There is a very real sense here that Henry is confessing as much to his spiritual papa as he is to his earthly papa, and that these two paternal roles are intermingled unexplainedly in the figure of Mr Fairchild. Neither of this scene's two analogues is satisfactory, however, since Mr Fairchild is neither a priest nor God, and yet his physical position and his tangible spiritual authority over Henry very clearly imply that he is an amalgam of both. Indeed, Mr Fairchild adds to this perception by shunning Henry with the brutal phrase 'I will not forgive you.' In doing this, Mr Fairchild further takes upon himself the power to approve or reject the use of ultimate clemency in a manner which once more seems to be reminiscent of a celestial rather than an earthly authority. Mr Fairchild's act of damnation and rejection becomes implicitly the act of God, and Henry's subsequent isolation is therefore total. Henry is taken away not only from his earthly community but also from the wider spiritual community of God's faithful, and 
only following his lonely prayers to Jesus will his father welcome him - the black sheep, the pariah, the monster - back into the fold. Only through confession and demonstration of repentance can Henry achieve a restitution that will satisfy his papa and save the little boy from the fires of hell. As Lynne Vallone succinctly puts it:

The threat of eternal damnation is a constant presence in much Evangelical writing for children, but in The Fairchild Family it is domesticated by obedience to an earthly father and a heavenly father. (One kind of obedience cannot exist without the other.) ${ }^{81}$

One cannot exist without the other indeed, because, as they are represented in the being of Mr Fairchild, Henry's earthly and heavenly fathers actually resolve into a single entity. Christianity is broken down here into Mr Fairchild's particular model of it, in which he - to bastardize the gospel of John - becomes the way, the truth, and the life. No-one, it seems, in The Fairchild Family can come to the Father except through the father.

\section{(iii) Knowing One's Audience: Dicing with Death}

Suddenly, then, The Fairchild Family seems to have unleashed hellfire in abundance. The happy atmosphere of its overview has dissolved into the megalomaniacal God-complex of Mr Fairchild, and the gruesome puppet-master-like management that he and, to a lesser extent, his wife exercise over their offspring. What once appeared to be a fairly innocuous narrative now does indeed appear to be terrifying, coercive, and of debatable appropriateness for children. And yet, in its extremity, in its terrificness, and even in its arguable unsuitableness for its implied audience, The Fairchild Family nevertheless makes for compulsive caricaturish reading. Herein, the delicacy of Sherwood's balancing act in the writing of this particular story is revealed. She has what she would clearly regard to be deeply serious instruction to impart and yet she does not want to present that information in a

\footnotetext{
81 Lynne Vallone, “A Humble Spirit Under Correction”: Tracts, Hymns, and the Ideology of Evangelical Fiction for Children, 1780-1820,' The Lion and the Unicorn, 15 (1991), 72-95 (p. 85).
} 
dry, didactic, boring, and - crucially - unmemorable framework. Remember that evidence suggests that this was a woman who loved a great variety of writing throughout the entirety of her life, and such a woman - no matter how motivated she may have been by her subject matter - would hardly want to write a book that was so arid that no-one would actually be interested in reading it. Therefore, whilst it is undeniably true that Mr and Mrs Fairchild are represented occasionally as being sinister, cloying, and monster-making in their behaviour towards their three children, this realization is accounted for by the fact that they are couched in a text which appears determined - whether consciously or not - to weave its imperative content into a garishly readable framework. Yes, these characters are extremities, but that extremity is actually their point. The Fairchild Family is a book which operates similarly to Samuel Richardson's Pamela, which (hypocritically, some might say) utilizes a semipornographic subtext to encourage its audience through its morally heavy-handed content. It also deploys comparable principles to those that sustained More's Cheap Repository, inasmuch as it establishes a simple yet addictively readable structure through which to impart its Christian lessons. The Fairchild Family is a book which even operates in equivalence with the writing techniques employed by that most modern of children's authors, Roald Dahl, who revels - alongside his regular artistic collaborator, Quentin Blake - in the exaggerated vulgarities that have made his many children's books so consistently appealing to their youthful audiences. Without a doubt, Sherwood intended The Fairchild Family to be excessive, to be scary, to be monstrous, because these are - secretly - some of its greatest marketing assets. Sherwood knew both what she thought her target audience needed and what she thought her target audience wanted. In The Fairchild Family, she gave them both.

The aspect of The Fairchild Family in which this salacious grotesquery can be found at its most effective is in the book's dealing with the subject of death. Given Sherwood's experience of bereavement throughout her life, with respect to the shock of her beloved 
father's departure and the later loss of her two children in India, it is easy to contend that she acquired a morbid interest in dying which subsequently made itself manifest in her work. Perhaps this is so - there is little evidence which can be used to argue against it - but her attitude to death in The Fairchild Family is much more akin, once again, to the black-humour excessiveness of Dahl than it is to any more solemn approach. There are four important death events in The Fairchild Family, of which the first is the scene for which the book is now best known. Relatively early on in the narrative, Emily is given a doll by one Lady Noble (a local gentlewoman) in exchange for Emily having found Lady Noble's lost diamond ring. Lucy is envious of her sister's new doll, and her mother tries to persuade her to talk through this new and wicked sentiment:

I love you, my child: notwithstanding which, I know that you have a wicked heart, and that your wicked heart will often make you unhappy where there is nothing else to make you so... Is there any thing in your wicked heart, my dear child, do you think, which makes you unhappy now?

Lucy subsequently confesses her heart's lamentable evil and Mrs Fairchild duly points her back on the road to righteousness, but Lucy's jealousy is not yet nullified. Use of the doll later causes a fight between the children which results in Emily and Lucy exchanging vows of hatred. Mr Fairchild, true to form, reads a sermonizing prayer over them and whips their hands, but remains unconvinced that they have fully learned their lesson. In order to impress upon them the full gravity of their actions, he resolves to take all his children - Henry included - to Blackwood to see a gibbet:

The man who hangs upon it is a murderer - one who first hated, and afterwards killed his brother! When people are found guilty of stealing, they are hanged upon a gallows, and taken down as soon as they are dead; but when a man commits a murder, he is hanged in iron chains upon a gibbet, till his body falls to pieces, that all who pass by may take warning by the example.

$$
\text { (FF, p. 57) }
$$


The premise upon which this scene is based is again an exaggerated form of Calvinism which declares that there are no venial but only mortal sins, and that a demonstrative analogy may therefore be drawn between the childish argument had by Emily and Lucy and the row which eventually led the man who now hangs at Blackwood to fratricide. Mr Fairchild recalls that the gibbet-man, whose name was Roger, killed his brother James out of envy, and that Roger was then sentenced to death when his crime was later uncovered. 'These brothers,' $\mathrm{Mr}$ Fairchild tells his daughters, 'when they first began to quarrel in their play, as you did this morning, did not think that death and hell would be the end of their quarrels.' $(F F$, p. 59$)$ Nor, one suspects, did Emily and Lucy, but that is precisely what they are now being taught: a quarrel over a doll will result in death on a gibbet. Clearly this sequence is just too inflated and too bizarre to be straightforwardly realistic, but, alongside Mr Fairchild's wanton dwelling on the decomposing details of Roger's corpse, it nevertheless imparts a good and basic lesson: try not to quarrel and be subject to hatred because to do so can have bad consequences. Maybe not everyone who fights over a doll will end up rotting on a scaffold, but the prospect of them doing so is strikingly memorable. This is not a lesson which it is easy to forget.

Now that the reader's appetite for deathly melodrama has been suitably stimulated, the next occasion when Sherwood whets it is at the death of the gardener, John Roberts. This scene, however, functions in a very different manner to that of Roger the brother-killer, because John Roberts has lived the life of a good man and his death therefore cannot be construed as a moral lesson in the way that the death of Roger can. John has lived worthily and has died simply of old age, and the only reason that the senior Fairchilds have to become involved in his departure is through their decision to go and pay their respects to his widow. This choice having been made, Mr Fairchild turns to his children and asks, as though he is offering them a tremendous treat: 
"Should you like to see the corpse, my dears?... You never saw a corpse, I think?"

"No, Papa," answered Lucy: "we should like to see one."

"I tell you before-hand, my dear children, that death is very terrible. A corpse is an awful sight."

"I know that, Papa," said Lucy; "but we should like to go."

$(F F$, p. 146)

In his allusions to death's terribleness and awfulness, Mr Fairchild could hardly make the prospect of seeing a corpse more appealing, and this exchange encourages the reader to be as engaged as Lucy claims the three little Fairchilds are by the prospect of seeing John's body. Mr Fairchild is, of course, incorrect to say that his children have never seen a corpse before, since it was he himself who introduced them to Roger's gibbet at Blackwood. Even after that seemingly forgotten experience, though, and even after $\mathrm{Mr}$ Fairchild's (unconsciously encouraging) admonitions about death's fearsomeness, his children are nevertheless unabatedly determined to see the body of the dead gardener. This leads first to a discussion on the nature of death, in which Mr Fairchild's dogmatic speech becomes positively Miltonic as he dwells rapturously on images of the inevitable Day of Judgment, ( $F F$, pp. 147-9) before the family eventually arrives at the Roberts' house and is admitted into the presence of the deceased:

At last Mr Fairchild said, "My dear children, you now see what death is: this poor body is going fast to corruption - the soul, I trust, is with God; and my reason for this hope is, that the poor man, when living, was a follower of the blessed Lord Jesus Christ, his Redeemer - but such is the taint and corruption of the flesh, by reason of sin, that it must pass through the grave, and crumble to dust. And this shews the exceeding sinfulness of sin, and its horrible nature, that the soul, which has sinned, must be born again, and the sinful body be dissolved and fall to dust in the grave..."

"Oh, sir!" said Mrs. Roberts, "it comforts me to hear you talk!"

$$
(F F, \text { p. 150-1) }
$$

Two sentiments operate across this scene. First, in spite of the situation's ostensible sobriety, Mr Fairchild's relish for the dissolution of the flesh inevitably draws the reader in to a voyeuristic appreciation of evangelical death theology. Second, after Mr Fairchild has 
finished his speech, Mrs Roberts' enthusiastic exclamation undercuts it by juxtaposing total seriousness with camp affectation. With the vocative 'oh, sir' at its beginning, Mrs Roberts' statement reads like a line which would not be out of place in one of the late twentiethcentury Carry On movies, and - although one suspects that this is not quite the tone that Sherwood was trying to achieve - this sort of reading is difficult to discount entirely. Mrs Roberts' is more than entitled to be delighted by Mr Fairchild's high esteem of her late husband's faith, but her manner of expressing her pleasure can hardly avoid drawing a smile. Thus, there is another palpable modal split here, between ultra-serious evangelical pedagogy at one extreme and disturbingly humorous Gothic thrill-seeking at the other, and the presence of the latter once again militates against the dryness of the former. Even tragic and holy deaths, it seems, can be used in the context of The Fairchild Family to offer a pleasurably morbid respite from the educational aridity of the book which surrounds it.

The most gruesome example of The Fairchild Family's death-fixation is to be found in the demise of Augusta Noble, the daughter of the aforementioned Lady Noble (whose family the book increasingly reveals to be an overpoweringly unpleasant and worldly group of people). Augusta's death is announced at the midpoint in Sherwood's narrative and is greeted with devastation at the Fairchild household: Mr Fairchild, normally immovable in his stoicism, is even forced to retire to his study when faced with the combined tears of his wife and children. ( $F F$, p. 154) Mrs Barker, another of the Fairchilds' neighbours, relays to them in detail the circumstances of Augusta's untimely (and hellfire-ridden) end:

Miss Augusta had a custom of playing with fire, and carrying candles about, though Lady Noble had often warned her of the danger of this, and had strictly charged the governess to prevent it. But it seems that the governess, being afraid of offending, had suffered her very often to be guilty of this piece of disobedience, without telling Lady Noble. And the night before last, when Lady Noble was playing at cards in the drawing-room, with some visitors, Miss Augusta took a candle off the hall table, and carried it up stairs to the governess's room. The governess was not in the room. Miss Augusta went to the closet, and it is supposed was looking in the glass, with the candle in her hand: but this is not known. Lady Noble's maid, who was in a room not far off, 
was frightened by dreadful screamings: she ran into the governess's room, and there found poor Augusta all in a blaze, from head to foot! The maid burnt herself very much in putting out the fire; and poor Miss Augusta was so dreadfully burnt, that she never spoke afterwards, but died in agonies last night - a warning to all children how they presume to disobey their parents!

$$
(F F, \text { pp. 155-6) }
$$

Spicy though this account undoubtedly is, none of its detail is in any way necessary to imparting the simple fact that Augusta is dead. Neither the reader nor the Fairchilds really needs this specificity in order to comprehend the intensity of the story's tragedy. There are, accordingly, only two narrative outcomes that can be used to justify Mrs Barker's extended account of Augusta's demise. The first of these is that Mrs Barker's words allow the communication of a multitude of pious lessons. In Augusta's conduct, the sins of lying, vanity, and stealing all lead towards her death, just as, in Lady Noble's conduct, the desire to play cards (rather than, it is implied, to attend to her parental duty) in turn contributes to her daughter's sad end. These are all bad things and they have all led to a bad conclusion. However, none of them are vices that the narrative has not dealt with before. Sherwood's book has already examined lying, vanity, stealing, and inadequate parentage, and - other than for the arguable sake of emphasis - it does not need therefore to examine them again here. Accordingly, the second and more realistic justification of Mrs Barker's report is that its gossipy thrillingness drives the scene and the narrative around it relentlessly forward with all the sensationalism of a tabloid article. Building its suspense from its opening mention of fire and candles, Mrs Barker's anecdote gives light to The Fairchild Family as it powers towards its blazing, screaming, burning, and agonizing finish. This makes for a deeply satisfying scene in which, yes, a child dies, but a child dies whom the narrative has previously established as a foul character and who thus deserves everything that she gets. This is hard justice but it is effective, and its lessons, again, are highly memorable. It operates once more upon the principle of dividing its sentiments between two extremes, in this instance of overt 
pathos and wanton fulfilment. There is sadness at the death of a young lady who was badly brought up and who, by implication, did not have much of a chance in the world. There is also, though, the disturbing pleasure of watching brutal justice being served; of being a witness to a death that is, in multiple senses, really well done.

The last of The Fairchild Family's death sequences is the genuinely affecting decline into illness of little Charles Trueman, ( $F F$, pp. 287-95) an especial friend of Henry's. Throughout the chapter in which this sad event occurs - titled, somewhat inevitably, 'A Happy Death' Charles spends his time locked in profound conversation with Henry, talking Henry through his biblically founded belief that death will provide deliverance for him from the pains of life. When Henry eventually goes to see his small companion for the last time, it is clear that the end is near:

[Charles] was much changed since the day before: his eyes were sunk, his face become deadly pale, and his mouth drawn close. When Henry looked at him, he could keep his tears back no longer; they overflowed his eyes, and ran fast down his cheeks.

$(F F$, p. 294)

The intimacy of this tableau, especially when it is compared to its predecessors, is acutely unsettling. Perhaps because Sherwood has previously built up a loving rapport with the character of Charles, or perhaps because Charles' death is happening now - in a present progressive sense - in the narrative, the power of this scene to impose death's enormity upon its viewers is unique. Clearly, as Charles dies with the words of Job's nineteenth chapter on his lips, $(F F$, p. 294$)$ there is a model being shown here of what the narrative thinks that death ought to be about. This is what The Fairchild Family's other deaths have been leading towards. This is the context in which those other deaths should be remembered.

Even here, though - even in this tragic and intensely religious scene - the narrative's caricaturish tendency still comes into play: 
[Charles'] frequent startings and convulsions, with his slow and solemn breathings, shewed that death was coming on apace... After a while his eyes half shut, and he fell into the agonies of death.

Death, even the death of those whose souls are redeemed, is a dreadful sight; for the sinful body struggles hard with it. Satan then does his worst: but it is written, "He that is with us is stronger than he that is against us;" and he will surely deliver those, whom he hath purchased with his precious blood, even from the power of death and hell.

After several compulsive pangs, little Charles stretched himself; he breathed slower, and slower, and slower; then, fetching a deep sigh, his features became fixed in death.

(FF, pp. 294-5)

This is not, in spite of the claim of its chapter's title, the most obviously happy of deaths: Charles patently suffers a lot. What is more interesting about it, though, is that even here even at the death of one who is good and holy - The Fairchild Family's narrative only affords one aside to reassure its audience that Charles is one amongst 'those whose souls are redeemed.' The rest of its text is given over again to the description of death's physical presence, of death's physical power, of those things about death that fascinate to the point of terrifying humanity, and of those things about death that persuade the viewer to keep watching.

\section{(iv) Making Memories}

To conclude, it is impossible to argue directly against assertions like those made by Carpenter with respect to The Fairchild Family. Evidently, Sherwood's book is, in many ways, very much a fearsome hellfire tract, and for none of these ways does it make any apologies. The fact that some treat its fearsomeness with deadly seriousness, however, is more problematic, because it seems quite clear that extremity in Sherwood's writing is used to create a demonstrative, revealing impact rather than to impart a literal template for familial life. There is no evidence, for instance, that Sherwood truly advocated the taking of children to see the gibbets of criminals, or that she revelled fetishistically in the physical processes of human decay. Nevertheless, such focuses within her writing ensure that the scenes in which 
they appear remain unforgettable, and that any underlying lessons which are shown in association with them become equally memorable as a result. Thus, not only does The Fairchild Family utilize the alienation of its child protagonists as a teaching tool (in a manner akin to the sensibility marginalization deployed by Day against the initial values of Tommy Merton), but it also uses powerful and extreme examples to impose upon its audience the idea that humanity is transient. This allows a dark fascination with the grotesque, equivalent to that seen in the work of modern children's authors like Dahl, to boil beneath the surface of The Fairchild Family, and to raise its monstrous and terrifying head to ensure that its audience is still paying attention, is still watching, and is still being demonstrated. In these terms, Sherwood's writing can in places become precisely that which it is so frequently accused of not being: darkly, sinisterly, and joyfully good fun. 


\section{CHAPTER SEVEN}

CHARLES KINGSLEY: EXPANDING MARGINS AND (MIS)READING THE WATER-BABIES 
In the earliest period of its concentrated production (ca. 1770-1830), English children's literature has now been shown to be a writing medium which, in the main, engaged prescriptively and didactically with its ostensible projected audience. Literature for children during this time was usually created in overt accordance with the theological, philosophical, and educational preferences of its writers, with a view to promoting to youngsters these viewpoints at the expense of all else. Against this background, children and the notion of childhood necessarily became reduced to tokens of cultural exchange - of ideological coinage - through which old arguments could be continued on the new battlefield of children's literature.

Whilst this sense of contestation is never lost during any stage of the children's canon, the English children's writers of the latter half of the nineteenth-century together succeeded in injecting a new and important feature into its process, i.e., fantasy. Walter de la Mare identifies this introduction as one which occurs alongside a sea-change in adult attitudes towards children:

None even of its kindliest apologists would deny that in the earlier years of the nineteenth century the attitude of mind towards children tended to the over-solemn - a state which resembles a lantern without any light in it. Excesses may secrete their own antidotes. The mothers and fathers who had been brought up on Scotch oats with a pinch of salt for savour were to realize that honey is also a provision of nature. ${ }^{82}$

Although the evidence collected here thus far demonstrates that at least the literary part of de la Mare's Scotch oats were not always quite as bland as he claims them to have been, the overall gist of his point nevertheless remains correct. The middle of the nineteenth-century marked out a period of growth in writing for children, as authors attempted to stimulate a wider imaginative breadth in their youthful audiences. The change that was signalled earlier

\footnotetext{
${ }^{82}$ Walter de la Mare, Lewis Carroll (London: Faber and Faber, 1932), hereafter WM, p. 8.
} 
in the Dahl-like descriptive excesses of The Fairchild Family was finally coming to fruition.

The margins of English children's literature were starting to expand.

The first truly significant contributor to this new developmental course was Charles Kingsley's The Water-Babies (1863), although, from the indifference with which readers both academic and more general - now treat it, one would hardly know it. With what is perceived to be the lumbering and somewhat confusing religiosity of its narrator, sitting all too close beside Kingsley's staunch promotion of English Protestantism, The Water-Babies has become increasingly regarded as a critical butt to be lampooned by comparison to the merits of its supposedly more worthy contemporaries. Although The Water-Babies has never been out of print since its initial publication, ${ }^{83}$ its enchantment is undoubtedly waning. The few studies of it which have been produced recently tend rather to comment on its diminishment instead of on the book itself. Without rectification, the ongoing process of what Deborah Stevenson poetically terms 'the drowning of The Water-Babies ${ }^{84}$ looks set to continue. Kingsley's consignment to the margins of the English children's literature canon appears to be assured.

The fact that such an important text has become bibliographically demonized in this way is, of course, one of the foremost features that make it so very noteworthy in the context of this thesis' theoretical discourse. Ironically enough, the other is that the central themes of Kingsley's book operate around the testing of borders, the investigation of boundaries, and the explosion of limitations: The Water-Babies is, as it were, a marginalized text which specifically and fantastically examines notions of marginalization. In order to give both of these features due attention, the analysis of them here will be split into three distinct phases. First, it will confirm what it is about The Water-Babies position in the canon of English

\footnotetext{
${ }^{83}$ Brian Alderson, 'Introduction,' in Charles Kingsley, The Water-Babies, ed. Brian Alderson (Oxford: Oxford University Press, 1995), hereafter $C K$, ix-xxix, hereafter $B A$ (p. xiii).

${ }^{84}$ Deborah Stevenson, 'Sentiment and Significance: The Impossibility of Recovery in the Children's Literature Canon or, the Drowning of The Water-Babies,' The Lion and the Unicorn, 21 (1997), 11230, hereafter $D S$.
} 
children's literature which immediately reveals Kingsley's to be a text which exists on and

defines literature boundaries. Second, it will examine the reasons that have led to the increasing abandonment of The Water-Babies by recent generations of readers, and it will link these reasons to Kingsley's use of his text to discuss the imposition and destruction of social and sociological margins in Victorian Britain. Third, it will argue that modern rejections of The Water-Babies are based primarily on incorrect, or at least inadequate, denigrations of its narrative competence, which are perpetuated by a critical determination to attack Kingsley and his personal values rather than accurately to evaluate his writing.

\section{(i) Marginal Demarcator}

The Water-Babies was initially serialized across eight editions of Macmillan's Magazine from August 1862 through to March 1863, and it was first published in book form in the summer of 1863. From its outset in Macmillan's Magazine, The Water-Babies' subtitle - $A$ Fairy Tale for a Land Baby - announced it as a type of story that was still relatively unusual to its contemporary audience. The Water-Babies is a fairy tale, a post-Romantic ${ }^{85}$ fantasy, and a story which - even if parts of its contents are located in nominal reality and include

${ }^{85}$ The Water-Babies contains a number of textual indicators which suggest that its post-Romantic context is significant to it. Although there is no documentary proof to confirm whether or not Kingsley had any especial preference for Romantic literature, the similarities between The Water-Babies and William Blake's 'Chimney Sweeper' poems (from Songs of Innocence and Songs of Experience) are too great to be coincidental. For example, not only does 'The Chimney Sweeper' in Songs of Innocence tell the story of 'little Tom Dacre' (my emphasis), but it also gives details of little Tom dreaming about an angel who comes to rescue all the dead chimney sweeper boys from their black coffins: 'Then naked \& white, all their bags left behind, / They rise upon clouds, and sport in the wind; / And the Angel told Tom, if he'd be a good boy, / He'd have God for his father \& never want joy.' (William Blake, 'The Chimney Sweeper,' in William Blake, Poems and Prophecies, intro. Kathleen Raine (London: Everyman's Library, 1991)) It could be argued that the similarities between Blake's poem and Kingsley's book arise merely through a chance consistency of their respective subjects, but with their shared images of nakedness, cleanliness, redemption, etc. - it seems more likely that a chain of influence exists between the two. It is worth noting also that Macmillan's decision to publish Alexander Gilchrist's two volume Life of William Blake: "Pictor Ignotus" at the same time as the first edition of The Water-Babies, allusively reinforces the link between Blake and Kingsley. Perhaps the most obvious evidence, though, of The Water-Babies' post-Romantic self-contextualization, is found in the material with which Kingsley introduces the chapters in the bound volume edition of his book. This includes extracts from Wordsworth's 'Lines Written in Early Spring' (Chapter 1), 'The Tables Turned' (Chapter 4), 'Ode to Duty' (Chapter 5), and 'Ode ("There was a time...")' (Chapter 6), not to mention Coleridge's 'Rime of the Ancient Mariner' (Chapter 3). 
morals to aid the lives of its ostensibly young audience - is meant to stretch the imagination. This is not to say that fairy tales did not exist in children's literature prior to Kingsley's investment in them. It is just to say that there are very few examples of popular books from earlier periods in the English children's canon that make such an explicit claim on the fantastical realm of fairies. Thus, even before its title page has been passed, The WaterBabies identifies itself as a textual herald which stands astride a border between the didactic realism of children's literature past and the imaginative fantasy of children's literature present. With its titular emphasis on fairy, it seems to favour the latter.

It is important, though, not to make the mistake of inferring that the fantasticalness of Kingsley's book necessarily intends to pull its readers away from realism. Writing about Kingsley and his approach to his writing, John C. Hawley observes that 'while encouraging the development of imagination... Kingsley did not conceive of children's literature as a refuge from the real world. ${ }^{86}$ A brief summary of Kingsley's activities throughout his life corroborates that Hawley's assessment is likely to be correct: Kingsley was, amongst other things, a minister, an advocate of Christian Socialism, a social reformer, a writer, a student of Darwinian evolution, a Regius Professor of History at Cambridge, and a tutor to the Prince of Wales. He was very much involved in his reality and he believed deeply that general reality - general life - could be made better through a combination of Christianity and education (probably in that order). We are not talking here, therefore, about a man who sought in literature a refuge from the real world. Instead, we are talking about a man who sought through literature to change it.

Care, then, needs to be taken when trying to separate Kingsley's work with social reality from his work with imaginative fantasy. In The Water-Babies, he seems determined to privilege the latter but not at the expense of the former. Criticism of The Water-Babies,

\footnotetext{
${ }^{86}$ John C. Hawley, 'The Water-Babies as Catechetical Paradigm,' The Children's Literature Association Quarterly, 14.1 (1989), 19-21 (p. 19).
} 
however, tends to ride roughshod over this balance by dealing in an overly segregative way with what may be termed the book's real section (Tom the chimney-sweep) and its fantastical section (Tom the water-baby). In such breakdowns, the latter is usually damned by comparison to the former, with little suggestion that the two might combine to form a constructive union. In fact, The Water-Babies' unity of design - or, rather, its supposed lack of it - is the issue that seems to dominate most academic commentaries on Kingsley's book. Q.D. Leavis writes that:

No child is going to have any difficulty in enjoying the magnificent first section [of The Water-Babies] which ends with Tom's apparent death by drowning. The trouble starts after this, when Kingsley, having exhausted the original inspiration and the élan with which he wrote the first chapter in half an hour and without correction, ${ }^{87}$ decided on a higher purposes, "to make children and their elders understand that there is a quite miraculous element underlying all physical nature."

Why Kingsley's decision to bring a higher purpose into his text should be regarded as one for which to condemn him, even if he did only make it following the completion of his first chapter, is not made clear by Leavis' essay. Nevertheless, the generally disparaging attitude of her piece is echoed frequently by others, such as John Rowe Townsend, who, in his wideranging study of children's literature, observes that:

The first chapters of The Water Babies, where Tom is a chimney-sweep, are splendid. There is no doubt that Kingsley could have written a first-class realistic story for children had he chosen to do so. Then there is a change of gear into fantasy as Tom enters the water. The second section, in the river, is also very fine in a different way. The watery passages are sensuous and poetic, and are written out of expert, loving naturalistic knowledge. In the later sections the story unfortunately grows ever more wild and woolly; Kingsley becomes entangled in his symbolisms and comes near to destroying his own work. ${ }^{89}$

\footnotetext{
${ }^{87}$ The persistent longevity of this version of The Water-Babies' initial conception - which comes from an account given by Kingsley's wife, Fanny - is incredible. As Alderson notes, Kingsley must have taken a good few hours to produce a mere draft copy of such a chapter. $(B A, \mathrm{x})$

${ }^{88}$ Q.D. Leavis, 'The Water-Babies,' Children's Literature in Education, 23 (1976), 155-63, hereafter $Q L$ (p. 157).

${ }^{89}$ John Rowe Townsend, Written for Children: An Outline of English-Language Children's Literature (Harmondsworth: Penguin, 1974), p. 99.
} 
Townsend, unlike Leavis, at least permits the possibility that there might be fineness to be found in The Water-Babies after Tom's descent into the river, but this allowance is still qualified by what he perceives to be the book's parallel descent into intractably dense narrative confusion. For Leavis and for Townsend, an alleged lack of consistent quality between The Water-Babies' two narrative phases prevents Kingsley's book from achieving its potential. In The Water-Babies, for them, reality and fantasy do not meet satisfactorily.

The repercussions of this problem - the idea that The Water-Babies is deprived of coherence (both with itself and with its author) as a result of its bipartite structure - cause Kingsley's book to be damned by its broader readership. Louis MacNeice, on vicious form, slams Kingsley by declaring that 'it is [his] own fault that [The Water-Babies] is neglected, since it is one of the most uneven and ragbaggy books in the language. ${ }^{, 90}$ It is with such terms that The Water-Babies has been banished from literary acceptability. It has become a piece which, because of its straddling of generic boundaries, its lack of willingness to fit into a definable literary category, is now ostracized as a monster on the boundaries of the canon. It has both delineated and expanded its contributory genres in a way which, quite simply, its audience frequently does not (or refuses to) recognize.

Deborah Stevenson tackles this subject from another angle, by arguing that the popular and academic survival of children's books (with especial emphasis on The Water-Babies) is dependent upon their successful entrance into what she refers to as 'a canon of sentiment:' $(D S$, p. 112)

Even beloved books... can eventually fall out of favor and memory. It is difficult to imagine indifference to a book one loves, and people tend to think if a text has made it past one generation then it will be beloved forever... There have already been books whose star has risen, hovered, and fallen again, despite the tacit assumption that a book whose popularity has survived to the adulthood of its audience will survive forever. The Water-Babies achieved that goal, but it is slipping from memory nonetheless. An adult seeking a book to give to a child picks up Kingsley's fantasy thinking not with

\footnotetext{
${ }^{90}$ Louis MacNeice, Varieties of Parable (Cambridge: Cambridge University Press, 1965), p. 83.
} 
nostalgia of a childhood memory worthy of sharing, but rather, "I think I've heard of this" - if s/he picks it up at all, or can find a copy to pick up. Academics note the text's historical significance, but Kingsley's book no longer has a place in the sentimental canon; the chain of affection has been broken. At some point, for reasons of taste, or marketing, or competition, or fashion, "Mother loved this" failed to become "I loved this" and "I want my children to love this." That failure is the loss of canonicity. Children's literature needs the generational chain of evidence, the handing down, to be canonical.

$(D S$, p. 126)

The loss of canonicity, identified by Stevenson, has occurred in the case of The Water-Babies at least partly in response to the sort of problems identified by Leavis, Townsend, MacNeice, et al. In a commodity driven textual market, the sort of literary difficulties posed by The Water-Babies are now tacitly understood by readers and publishers alike to be more trouble than the book is worth. Puffin, for example, a well established and respected producer of children's material, does not at present print an uncensored edition of the book because certain points in it - which are notably not referenced - have been deemed too sermonesque for popular taste. ${ }^{91}$ This closed-door decision is mirrored by the views of a large swathe of the academic community, which says, to return to Leavis, that:

It had better be admitted that for infant-school children (ages 5 to 7) [The WaterBabies] needs reading aloud selectively, with judicious skipping of the unpalatable parts (for that age-group) where Kingsley forgot he was supposed to be writing a book for his five-year-old son Grenville and made digressions, often satiric or obscure, more suitable for his three older children... not to mention such longeueurs to amuse himself as affected sentences modelled on his favourite Rabelais... An edited edition might well omit some of Kingsley's imperfect sympathies, such as Welsh and Irish characteristics, Tractarians, American-type democracy, etc., in which passages he was partly joking tastelessly and partly blowing off steam.

$$
(Q L, \text { p. 155) }
$$

In other words, instead of trying to tackle the problems addressed in and caused by The Water-Babies, the consensual policy of both publishers and professors appears to be that it is

\footnotetext{
91 'In this abridged Puffin version of The Water Babies, the passages of blatant sermonizing have been removed, although the background is still clear: the hero, Tom, is a badly treated "climbing boy" - a chimney sweep - until he escapes to find adventure as a Water Baby in an underwater realm.' (Anon., in Charles Kingsley, The Water-Babies: A Fairy Tale for a Land-Baby (abridged) (London: Puffin Books, 1994), p. ii)
} 
best to amputate the book's most troublesome - and intriguing - paragraphs. The reason given for this course of action is that the abstract body of innocent child readers, towards which the book is purportedly targeted, needs to be defended from the complexities of Kingsley's narrator. This, though, forgets that The Water-Babies was not originally published for child readers but rather for a select body of magazine-reading Victorian gentlefolk. At the same time, this modern process of undocumented editorial pruning serves to exacerbate one of the main textual misdemeanours for which The Water-Babies was criticized in the first place, i.e., its supposed lack of author-controlled developmental narrative coherence.

To summarize, approaches to The Water-Babies like those that we have considered thus far seem to turn back on themselves and become inward looking. Something new is required in order to move this investigation forwards. With this is mind, let us review the facts of the matter as we now have them. First, for whatever reason(s), The Water-Babies is no longer the popular book that it once was. It exists now merely as a monstrous border-wanderer on the edge of the canon of children's (and indeed more general) literature. Second, The WaterBabies was, in its time, an innovative and border-straddling book, in its combination of factuality with fairyland and morals with mellifluence. Third, The Water-Babies' divides its textual content into two (if not more) unequally sized sections, which chart the progress of its protagonist, Tom, from human child to water-baby and beyond. Heretofore we have focussed on the first and second of these points, in order to demonstrate that - even at a bibliographical level - The Water-Babies is ever engaged by the issues of marginality that are announced by the novelty of its subtitle. We need now, in order to further this discussion, to move on to considering the details of Kingsley's text. 
The reader's introduction to The Water-Babies is made through Kingsley's description of the character of Tom, the chimney-sweep. Tom is a child who is stuck in a rut of destitution and insecurity. He works for money, which is spent by his master, Mr Grimes. Tom is therefore deprived of financial security. Tom can neither read nor write. He is therefore without (certain aspects of) communicative and educative security. Tom has never been taught to say his prayers and he knows nothing of God. He is therefore bereft of spiritual security. Yet, against all these odds, Tom's life is not wholly miserable. In fact, the narrator's description of it divides it evenly between sadness and happiness:

[Tom] cried half his time, and laughed the other half. He cried when he had to climb the dark flues, rubbing his poor knees and elbows raw; and when the soot got into his eyes, which it did every day in the week; and when his master beat him, which he did every day in the week; and when he had not enough to eat, which happened every day in the week likewise. And he laughed the other half of the day, when he was tossing half-pennies with the other boys, or playing leap-frog over the posts, or bowling stones at the horses' legs as they trotted by, which last was excellent fun, when there was a wall at hand behind which to hide.

$$
(C K, \mathrm{p} .8)
$$

Tom, then, is defined from the outset of The Water-Babies as a child on a cusp, who is forever caught between extremes. He is sad but he can be happy. He is naughty ${ }^{92}$ but he retains the capability to be good. ${ }^{93} \mathrm{He}$ is dirty but he aspires to be clean. He is a child on a border which, to realize his hitherto unfulfilled potential, he wants to cross.

The last of these definitions, and the point towards which all of the others are directed, is expanded by Valentine Cunningham, who contextualizes The Water-Babies amidst the fairy tale discourse of the ash-brother:

\footnotetext{
${ }^{92}$ Tom drinks, gambles, attempts to hurt animals, has been in gaol, and looks forward with relish to the days when he can keep apprentice chimney-sweeps and treat them every bit as badly as Grimes now treats him.

${ }^{93}$ When the Irishwoman, whom Tom and Grimes meet on the road to their commission at Harthover Place, declares that all those who wish for cleanliness will find it, $(C K, \mathrm{p} .12)$ her intended audience is Tom, since she knows full well that he has the capacity to be a better boy than he now is.
} 
The ash-brother - whether Abel, Esau, Aschenbrödel, or Cinderella - is that member of the family who is neglected, not-cherished, cast-out, defrauded of his/her birthright, and who is severely put-upon, exiled in various ways, even done to death, by some more prosperous, lucky, cunning, powerful, better-organised member or group of members of the family. As a model for the Victorian working-class, especially its children, in relation to the Victorian bourgeoisie, the figure of the ash-brother could not be more apt. The essence of the ash-brother's plight is that he has been driven away to the margin, the border, the edge: that place... for doubtful, feared people and substances, the place of the physical exuvia that are ejected and rejected at the margins of the human body, the skin (that edge), the exits at the borderline of the body, the place of human debris and castaways, people construed as discardable and inferior, the place where sanity is at hazard ("on the border"), and where the wholeness of societies, individuals, and writings is most in question. ${ }^{94}$

Cunningham's clause-piling, effluvious, and abject-reminiscent ${ }^{95}$ description of this common fairy character, embodies Tom absolutely. Indeed, Cunningham goes on to argue that Tom's ash-brother status within The Water-Babies should be regarded as one of peculiarly high emphasis, since Kingsley's narrator states that 'the wisest man knows only the very smallest corner [of this world], and is, as the great Sir Isaac Newton said, only a child picking up pebbles on the shore of a boundless ocean.' ( $C K, \mathrm{p} .40)$ If it is inferred from this that The Water-Babies' narrative position is that all members of humanity can only ever be borderwalkers with respect to the grand wonder of the world's creation, then those humans who are isolated by their peers to become ash-brothers must approach a notional superlative in their degree of social segregation. ( $V C, \mathrm{p} .127)$ Tom, therefore, is an outsider from a community of outsiders, who is written about in a book which inhabits generic borderlands at best and is a complete bibliographical outcast at worst:

And thus is Tom presented. His working day is timed for the edge of the lives of "fine gentlemen and ladies." He gets up at 3 a.m., so that he's "just ready to get up when the fine gentlemen and ladies were just ready to go to bed" (Ch. 1). In classic Cinderella fashion he's laughed at and rudely pointed at by the more fortunate boys at the little Dame's School on the river bank (Ch. 2). The girl pupils at the School cry when he shows up. The Dame herself pities him alright. But she nevertheless puts him in "an

\footnotetext{
94 Valentine Cunningham, 'Soiled Fairy: The Water-Babies in its Time,' Essays in Criticism, 35 (1985), 121-48, hereafter $V C$ (pp. 125-6).

95 Julia Kristeva, Powers of Horror: An Essay on Abjection, trans. Leon S. Roudiez (New York: Columbia University Press, 1982).
} 
outhouse" because he's too dirty for anything better. "If thou wert a bit cleaner I'd put thee in my own bed, for the Lord's sake. But come along here": even the Good Samaritan flinches from the ash-brother and seals him in the outcast position.

$(V C$, p. 127)

Thus indeed is Tom presented: he is a quite literal, and very monstrous, ash-brother. He is a child who gets covered in soot and who, notwithstanding his tendency towards naughtiness, is eventually hounded to the very edge of his human life for committing a crime no worse than coming down the wrong chimney and standing on a hearth whilst being dirty. (CK, pp. 16-34) He is criminalized for coming too close to the border between his world, with all its literal and metaphorical working class griminess, and the bourgeois sanitary domesticity of the world of Ellie, the little girl into whose pristine room he mistakenly tumbles after he gets lost in the Harthover chimneys. Tom runs away from this transgression for a sin no greater than being grubby. He is brought, at the end of his real life, to a new border on the other side of which he can be made clean.

It is usually at this point in The Water-Babies that Kingsley's critics begin to decry his narrative technique. The logic for this is that his book has, until the end of Tom's flight from Harthover, been a pretty standard critique of the relationship between the social classes of Victorian Britain, which is combined transparently with elements of Christian allegory. Such fare is to be expected and is acceptable from Kingsley the socialist, Kingsley the priest, and Kingsley the didactic tutor. Such fare flatters the reader's expectations and leaves them undisturbed. However, after Tom runs away, meets the old dame, and subsequently descends into the river which runs alongside her school, Kingsley's book clearly starts to become more complicated and more confusing. Tom, after all, now begins a new teleological investigation of life which is aided and abetted by an assortment of creatures and a couple of theologically ambiguous fairies. The Water-Babies is no longer quite so comfortable because the reader is no longer quite so certain about its direction and agenda: this underwater world into which 
Tom has moved seems to have little or no bearing on its predecessor. In a narrative, and possibly even in a mental sense, Kingsley looks as though he has lost the plot.

Or has he? To validate such an assertion, one needs to assume that there is a given way in which texts should perform, as Leavis does when she comments that, on certain occasions, 'Kingsley forgot he was supposed to be writing a book for his five-year-old son Grenville' (my emphasis). For Leavis and for critics like her, The Water-Babies should be a clearly motivated and monotypic text, but this consistency is disrupted for them by Kingsley's decision to shift his protagonist between the modes of realism and fantasy. Yet, when push comes to shove, what actually changes for Tom when he steps into the river and becomes a water-baby? Yes, the river represents a border between the realms of Tom's previous world and those of another prospective world, and yes, Tom manages to move through it as a result of his desire to be washed and to be clean. Yes, he evolves past, progresses from, and is made superior to the class-ridden, judgemental, and seemingly irreligious inhabitants of the reality that used to be his normal place of residence. Yes, he is, sublimely and transcendentally, made into a water-baby. Yes, he is pushed beyond what he was to be become a higher calibre of being.

Yet, in truth, the real world which Tom has left is mirrored distinctly in the fantastical underwater environment in which he newly finds himself. To his benefit, Tom is no longer externally dirty, and he no longer has any chimneys to sweep, but these - other than 'having round the parotid region of his fauces a set of external gills' $(C K$, p. 39) - are the only major advantages that he has acquired over his previous situation. His life is still, for example, plagued by class differentiation which is still made manifest through inter-class violence. The animals which he meets 'describe the differences between the species in terms of social 
relationships rather than of natural selection or evolution, so physical nature and social identity blend together. ${ }^{96}$ In the words of the female otter:

[Salmon] are the lords of the fish, and we [the otters] are the lords of the salmon... We hunt them up and down the pools, and drive them up into a corner, the silly things; they are so proud, and bully the little trout, and the minnows, till they see us coming, and then they are so meek all at once; and we catch them, but we disdain to eat them all; we just bite out their soft throats and suck their sweet juice... and then throw them away, and go and catch another.

(CK, p. 59)

In real terms, then, Tom's aquatic life is not in fact so different from or irrelevant to his terrestrial life as is commonly thought: as with anything that is put underwater, it may look different to the external observer, but this is only because water has refractive properties and distorts the images of things that are seen through it. Tom has undoubtedly passed over a border by stepping in to the river, but the movement that his character has achieved by doing so is no more than fractional. If, as a human, he existed on the very edge of a water-surface thin margin, then, as a water-baby, he exists on just the other side of it. His proximity to the real world and his character's potential to castigate it, have barely changed at all.

The point is, of course, that even when real Tom is reborn or metamorphoses to become a fantastical water-baby, he remains a no-less-potent vehicle through which Kingsley can attack what he perceives to be the marginalizations, exploitations, and follies of Victorian society. Tom the water-baby is still as much a monster, a demonstrator, as ever he was. As Cunningham points out, from the moment of Tom's transition, The Water-Babies - even more than it did before - 'offers a potent drama of the... degradation of apartness and margins.' $(V C$, p. 129) The water-babies are affected by this apartness and these margins, and Tom's transformation to become one of them makes their fantastical existence and

\footnotetext{
${ }^{96}$ Mark Loveridge, 'The Water-Babies' (unpublished lecture notes, University of Wales Swansea, n.d.), hereafter $M L$. Mark Loveridge gave me access to these notes after it was brought to my attention that he used to lecture on The Water-Babies at the University of Wales Swansea as part of a class series on narratives. Since these notes are neither published nor paginated, pagination to a physical edition is not offered here.
} 
experiences more immediate, more intimate, and more relevant to those who read about them:

Only where men are wasteful and dirty, and let sewers run into the sea, instead of putting the stuff upon the fields like thrifty reasonable souls; or throw herrings' heads, and dead dog-fish, or any other refuse, in to the water; or in any way make a mess upon the clean shore, there the water-babies will not come, sometimes not for hundreds of years... but leave the sea-anemones and the crabs to clear away everything, till the good tidy sea has covered up all the dirt in soft mud and clean sand, where the waterbabies can plant live cockles and whelks and razor shells and sea-cucumbers and golden-combs, and make a pretty live garden again, after man's dirt is cleared away.

$(C K$, p. 102)

Kingsley's metaphor here is quite clear: one can either push all one's effluvium - whether it is sewage, herrings' heads, or little chimney-sweeps - to the margins of one's existence and ignore it, or one can be responsible and deal with it. The first of these approaches, by implication, destroys health and beauty en route, and therefore degrades both the life of the person who lazily adopts it and the lives of those who have to cope with its unwanted products (in this case, the water-babies). Idleness of whatever sort is intolerable in The Water-Babies because idleness breeds misunderstandings of margins, borders, and the significance of those things that can be found at them. Even the world's wisest men, like Professor Ptthmllnsprts, standing on the margins of the sea into which men tip all the waste with which they cannot cope, will not believe the empirical evidence of their own eyes when faced with something that is so apart that it might shatter their indolently cosy preconceptions of the way in which the world works. Ptthmllnsprts sees Tom, the water-baby, but refuses to credit the idea that what he sees is real because to do so would mean that he would have to change his established perception of life. This would require activity and Ptthmllnsprts' character cannot cope with that. Even when Ptthmllnsprts manages to catch hold of Tom, he still cannot admit to Ellie that he is actually holding a water-baby. Such a thing is to him, as the responsorial implied reader determinedly states in Kingsley's second chapter, 'contrary to 
nature.' (CK, p. 39) It is no mistake that Ptthmllnsprts' chair is in 'Necrobioneopalæonthydrochthonanthropopithekology:' (CK, p. 81) the irony of an ostensible naturalist whose professed discipline begins with dead life would not have been lost on Kingsley. Ptthmllnsprts is a researcher into pickled life (put-them-all-in-spirits), preserved life, and life as he already knows it to be. When Tom eventually bites him, the Professor is therefore all too glad to throw the water-baby back into the sea: out of sight, out of mind; throw it over the margin; it does not exist. Such sedentariness and slothful reinforcement of the status quo are, in The Water-Babies, signs of regress not progress. Such approaches to life, as advocated by Ptthmllnsprts and to a greater extent in the later characters of the Doasyoulikes, produce what may be thought of as a Kingsleyan model of Darwinian de-evolution. ${ }^{97}$ Here, the participants do not move forward at all, but rather return - metaphorically and literally - to primordium:

And in the next five hundred years [the Doasyoulikes] were all dead and gone, by bad food and wild beasts and hunters; all except one tremendous old fellow with jaws like a jack, who stood full seven feet high; and M. Du Chaillu came up to him, and shot him, as he stood roaring and thumping his breast. And he remembered that his ancestors had once been men, and tried to say, 'Am I not a man and a brother?' but had forgotten how to use his tongue; and then he had tried to call for a doctor, but he had forgotten the word for one. So all he said was, 'Ubboboo!' and died.

Kingsley here deems that the equality query made famous by Josiah Wedgwood's antislavery medallions does not deserve to be spoken by the last Doasyoulike, who in turn confirms his fate by asking for mercy as a dumb animal when he would have shown none to those creatures that his people in their heyday would have treated as dumb animals. He becomes a foul monster where once he made and exploited monsters. He, in the pragmatic

\footnotetext{
${ }^{97}$ It is frequently noted of Kingsley that he was an avid early reader of Charles Darwin's Origins of Species (1859). See, amongst others, Arthur Johnson, 'The Water-Babies: Kingsley's Debt to Darwin,' English, 12 (1958-9), 215-9.
} 
and harsh social and sociological terms of The Water-Babies, is responsible both for his speechlessness and for his death.

Against The Water-Babies' clearly developing narrative critique, which remains entirely consistent with the issues raised in its reality located initial section, the typical academic response to Kingsley's book now seems somewhat surprising. There is a clearly developing train of thought here, which leads logically from Tom's rejection at Harthover into the (admittedly refractive and therefore both illusive and elusive) underwater world of the waterbabies. Why do so many analysts have a problem with this framework? The answer is to be found in the brilliant - perhaps too brilliant - duplicity of Kingsley's narrative technique. The Water-Babies, remember, is subtitled A Fairy Tale for a Land Baby, which seems to make children its implied audience. However, it was first published in Macmillan's Magazine, which seems to make adults its implied audience. ${ }^{98}$ A logical solution to this apparent dichotomy in The Water-Babies' intended readership can be found in the idea that the adult context of the book's initial publication would have encouraged the book's older readers to read it aloud to youngsters. It was, as it were, a book being offered to adults for use with their own children. However, this explanation presents its own problem, which is that a goodly number of the adults who would have had access to The Water-Babies through Macmillan's Magazine would themselves have possessed some if not all of the negative societal qualities that Kingsley's narrator so aggressively attacks. They would have been

\footnotetext{
${ }^{98}$ The material which surrounds The Water-Babies, in the eight editions of Macmillan's Magazine in which it appears, demonstrates that the journal has a highbrow projected audience. On the pages of Macmillan's Magazine, political material - particularly American - shares space with a poem by Christina Rossetti (March 1863), a review of a collection of Arthur Hugh Clough's poetry (August 1862), and a theosophical essay by Matthew Arnold (January 1862), to cite but a few of the more significant contributions. The relevance of this context can be argued in two ways. First, among the subscribers to Macmillan's Magazine, there would have been those who came to it for an involved, possibly even a combative reading experience - those who we may think of as the journal's thinking readership. Second, there would have been those who came to it who merely wished to give the impression of desiring the above experience, whilst actually being apathetic to such matters - those whom we may think of as Macmillan's Magazine's coffee table readership. In order for The WaterBabies to be successful in this context, it would have to satisfy both of these audience types, although, as this chapter implies, The Water-Babies' divergent audiences would have been likely to get very different things out of their readings of it.
} 
lazy, they would have been sedentary, and they would have abused the margins and boundaries of their society. In order to ensure The Water-Babies' successful propagation, therefore, a layer of narrative duality needed to be incorporated into it to ensure that none of its adult audience could read it as a text which ran in flagrant opposition to their way of living:

If The Water-Babies is to be a genuine heterotopia, a fantasy- or absurd world AND ALSO partly a straight reflection of the world, this has important consequences for the book's ideological stance. It means that it has to reflect the Victorian social and political world as a mirror of the world of natural selection and natural law, the survival of the fittest. It has to reflect the values of social Darwinism, it has to allow the dominant voice of the narrator to express these values. The notorious Puffin edits The Water-Babies for political correctness, because the narrator is at some points beautifully politically incorrect, which is to say that he is sometimes VERY politically correct as far as Victorian values go.

In other words, the narrative of The Water-Babies is exceptionally good at overtly giving its adult readership precisely what it believes that the majority of them will want (i.e., something akin to Ptthmllnsprts' static life as he already knows it to be) whilst simultaneously mocking these same practices behind their backs. With its faux-conservatism, cod-racism, pseudocolonialism, and determination to destroy the credibility of unwitting readers by forcing them on occasion to read complete misinformation, ${ }^{99}$ The Water-Babies is laughing audibly at those who read it as a simple monogenous children's story. The whole purpose of this book is, on a surface reading, to support the Victorian standards on which it commentates, whilst decimating those standards when it is perused more deeply. By doing so, it concurrently represents the social polarities of Kingsley's writing career, from the working class

\footnotetext{
${ }^{99}$ The beginning of The Water-Babies third chapter, with its sardonic and entirely fabricated Government pupil-teacher explanation of the adjective amphibious, provides but one example of this syndrome. 'Amphibious. Adjective, derived from two Greek words, amphi, a fish, and bios, a beast. An animal supposed by our ignorant ancestors to be compounded of a fish and a beast; which therefore, like the hippopotamus, can't live on the land, and dies in the water.' $(C K, \mathrm{p} .47)$
} 
radicalism that inhabited his earlier works (such as Alton Locke) through to his later status as an apparently keen participant in the middle class establishment.

What it is vitally important to understand about The Water-Babies, though, is that, whilst the death of Tom and his descent into the world beneath the water is undoubtedly an important feature in the book, inasmuch as it is a clear indicator on the path of Tom's moral evolution, it is nevertheless neither the beginning nor the end of that evolutionary path. It is merely part of a wider whole, in which, as we have already seen, the scale of Tom's translocation from his terrestrial life to his under water life is no greater than the thickness of water's surface. In this context, Tom's metamorphosis is actually something of a red herring, which is deployed to offer the succour of an unreal fairy landscape to those readers for whom the acidity of Kingsley's social attack might otherwise become too apparent and too great. For those, though, who see continuity rather than difference between Tom's two living environments, the little boy's movement from real world to mirror world serves to highlight the static - and, in Kingsley's terms, inherently flawed - societal background against which Tom's moral evolution is defined.

What seems to have happened, both in criticism of The Water-Babies and in its reception amongst more general readers, is that the significance and even the presence of this audience juggling-act has been lost. Devoid of any sense of its original Macmillan's Magazine textual context, as The Water-Babies so frequently is when it is presented to modern audiences, an appreciation of it like the one detailed here becomes impossible. Even in the presence of this textual context, a superficial and inaccurate expectation of The Water-Babies can be raised, which suggests that it should function as a straightforward story that will readily reconcile with the reader's perception of Kingsley's social position and with the marginalizing standards of wealthy Victorian life. Instead, what is actually offered is a karmic tale, in which life in nature - no matter how fantastical or fanciful its representation - is governed by 
causality. In this latter story, the closest that Kingsley gets to the Victorian orthodoxy which so many of his readers seem to expect from him is to be found in the multipartite structure which he gives to the figure of The Water-Babies' fairy God/Mother. Even this, though, is only revealed at the book's end, when she discloses herself as one who embodies many facets in a single entity, like a misshapen and indefinable version of the Christian Trinity or a fairy personification of Mother Church. Indeed, in her socialistic causal assault on the orthodoxy of the nineteenth-century's religious establishment and its wealthy supporters, Kingsley's fairy seems at times to be the epitome of the mechanized Victorian imperialism which gives rise to that establishment. Speaking as Mrs Bedonebyasyoudid, she says that:

I am the best friend you ever had in all your life. But I will tell you; I cannot help punishing people when they do wrong. I like it no more than they do; I am often very, very sorry for them, poor things: but I cannot help it. If I tried not to do it, I should do it all the same. For I work by machinery, just like an engine; and am full of wheels and springs inside; and am wound up very carefully, so that I cannot help going.

(CK, pp. 107-8)

This machine-like industrial discourse of causal inevitability - a process which cannot help going and which is subject neither to human intervention nor human prevention - is hardly the voice of the ostensibly caring God of the New Testament. Yet the significance of Mrs Bedonebyasyoudid and her other forms arises precisely from the fact that they exist in effective unspoken mutuality with that selfsame God. The metaphorical and paradoxical cocktail which results from this and The Water-Babies' other comparable acts of jamming together seemingly irresolvable concepts is absolutely what Kingsley's book is about. It is about finding logic in contradictions and making sense of absurdities.

Mark Loveridge is particularly helpful on this subject. He provides, for example, a rationalization of The Water-Babies' gloriously weird final chapter which once more takes shape around the idea that The Water-Babies is a text which is meant to be read to children. Following Grimes' relegation to Etna's crater, wherein he is to sweep indefinitely to atone 
for his life's sins, the relationship between Tom and Ellie is finalized by the words of both the implied child listener and the implied adult reader:

So Tom went home with Ellie on Sundays, and sometimes on week-days too...

" And of course Tom married Ellie?"

My dear child, what a silly notion! Don't you know that no-one ever marries in a fairy tale, under the rank of a prince or princess?'

Loveridge follows this up brilliantly by writing that:

So, the Victorian father realises, with what's left of his hair standing on end, that he has been bamboozled into reading [his] precious infant a Rabelaisian tale which closes with dubious phallic symbolism [in the form of what we would now read as the distinctly Freudian policemen's truncheons, who guard Grimes and his companions], illicit passion, and unbridled unmarried going-home-with, filled with disturbingly unEnglish religious mythology, all disguised as a moral fairy-story with pseudo-Christian overtones, written by a Victorian clergyman! And Tom and Ellie's liaison has no moral overtones or consequences at all!

\section{$(M L)$}

For those who misread The Water-Babies as an attempted attack on but ultimate reinstatement of the values of Victorian Britain, this final and unlicensed coming-together of boy and girl must constitute the destruction of all that is proper. The Christian religion is here having at least one of its core values denigrated by a writer whose social position as a priest dictates that he should actually be engaged in their promotion. Fortunately for this audience, Kingsley's narrative - remembering that it needs to satisfy a divergent readership offers a convenient get-out clause: 'But remember always, as I told you at first, that this is all a fairy tale, and only fun and pretence; and, therefore, you are not to believe a word of it, even if it is true.' ( $C K$, p. 184) Thus, such amoral crises can quickly be dismissed as issues that are relevant only to Kingsley's choice to write in the fairy tale genre, in which strange and disturbing and abnormal events can occur without having the slightest consequence in or implication for the world which exists outside the book. In fact, this actually makes The 
Water-Babies into a rather good joke - a book which almost encourages exaggeratedly serious readings of daft little fairy stories.

To those for whom The Water-Babies' monstrosity reveals information on a deeper level, however, Kingsley's conclusion to his book begs an alternative explanation. If Tom's evolutionary moral progress has been defined throughout by Kingsley's fairy's principle of causal deservedness - punishment when Tom is naughty, and reward when he is good - then The Water-Babies' narrative, although cautious of giving a premarital union its complete approbation, must nevertheless deeply approve of Tom's partnership with Ellie. The fact that they do not - indeed, the narrative tells us that they cannot - marry is a reflection not on the value of their relationship but rather on the marriage-values of their fairy tale society. Princes and princesses (upper class people with money) can marry and be blessed by matrimony's social significance, whereas hard working paupers (a status to which Ellie has shifted, despite her affluent origins) do not receive such license. Upon what does this reflect most negatively: the unlicensed paupers or the society that denies them license? Once again, what is being achieved here is a final attack upon the emptiness of Victorian class schematics, even those of systematized Christianity, in which the marital status of relationships has been made more important than the work which has been put into ensuring their spiritual deservedness. That Kingsley has left this parting shot so open to interpretation may suggest that a concentrated and direct attack on the doctrines of his church was not one that even he could countenance, but, in a book which has so consistently dealt with the moral consequences of stagnation as opposed to evolution, this reading cannot be discounted. Tom and Ellie have worked towards one another, demonstrated fidelity to each other, and deserve their eventual going-home-together time. This is their right moral and spiritual ending, and its apparent lack of religious and societal licence is irrelevant. And, of course, if this demonstration of true relational value becomes too much for the reader, the book can always 
be put down and left alone. After all, as its narrator puts it, it is not as though The WaterBabies can force us to believe in it, even if it is true. 


\section{CHAPTER EIGHT}

LEWIS CARROLL: WHO THE F**K IS ALICE? 
The abundance of criticism now available on Lewis Carroll's Alice serves as much to complicate as it does to clarify her character. In part, there is a very good and simple reason for this: Alice is, inescapably, complicated, and scrutiny of her necessarily draws out this complicatedness. However, there are three common problems that pervade evaluations of Carroll which obscure his Alice unnecessarily and inaccurately. First, the manifold implications of the distance between Charles Lutwidge Dodgson and Lewis Carroll are frequently ignored in such writing, thus disregarding the significance for Dodgson's work of his decision to publish it under a pseudonym. Second, and logical successor to the first, Carroll's Alice is often and mistakenly treated as a character who is wholly dependent upon a perceived relationship between her and Alice Liddell, the little girl known by Dodgson who supposedly became the real life model of Carroll's Alice. Finally, modern combined editions of Alice's Adventures in Wonderland (1865) and Through the Looking-Glass and What Alice Found There (1871) encourage in contemporary criticism the incorrect notion that these two books - published initially a number of years apart - can be conflated, by implying that their author conceived of them as a single volume work.

Against the background of these difficulties, a striking consistency nevertheless remains in Alice's character, which is that she comes under concerted mental attack from adult figures and grown-up environments in both the major books in which she features. Consequently, Alice's identity is always in crisis (pulled apart by adult social games and conventions that she does not understand) and she becomes recognizable only as one who is monstrous, one who it is difficult to know, and one who barely even knows herself. Who the $\mathrm{f}^{* *} \mathrm{k}$, indeed, is Alice ${ }^{100}$ To represent effectively her disintegrative identity and its predicament, we need initially to examine and subsequently dispel some of the critical

\footnotetext{
${ }^{100}$ This somewhat explicit question is not quite so arbitrarily self-indulgent as it might at first appear. It is taken from the chorus to a song called 'Living Next Door to Alice,' which was first recorded by Smokie in 1976. Although the Alice in Smokie's track has nothing whatsoever to do with Carroll's Alice, the immediate applicability of this querying refrain to Carroll's young protagonist is simply too good and too relevant a contextual opportunity to miss.
} 
difficulties caused by conflations of the relationships between Dodgson and Carroll, and Alice Liddell and Carroll's Alice. These can then be fed into individual discussions of Carroll's two texts, in order to examine the selfhood dilemma of, and in order to get closer to, the fractured and demonstrative identity of their namesake protagonist.

\section{(i) Approaching Alice: Charles Lutwidge Dodgson vs. Lewis Carroll}

Charles Lutwidge Dodgson was born in Daresbury, Cheshire, on the $27^{\text {th }}$ January 1832 , the third child from the marriage of the Revd Charles Dodgson and Francis Jane Lutwidge. An ebullient young man, he matriculated from Christ Church at Oxford in the Trinity term of 1850 , and, having achieved a $1^{\text {st }}$ Class Degree in Mathematics in 1854 , was nominated for a Studentship at his College by Dr Pusey (he of the Oxford Movement and an old friend of Charles Dodgson senior). Dodgson's attachment to Christ Church remained undiminished throughout the rest of his life, most of which was spent in the College as a residentiary Tutor of Mathematics. He was ordained deacon in 1861.

Dodgson's decision to construct a pseudonym for his writing persona was made in 1856 , at a time when he was a literary contributor to the newly established periodical, The Train. According to Stuart Dodgson Collingwood (Dodgson's nephew), four names were mooted as being suitable for this task. The first two were formed by anagrammatically rearranging the letters of Dodgson's forenames, and the last two by Latinizing and subsequently reAnglicizing his forenames. The latter of these four - which was formed by converting Lutwidge to Ludovicus to Lewis, and Charles to Carolus to Carroll - was favoured by Edmund Yates, The Train's editor, and it thereafter became inscribed as Dodgson's literary nom de plume. ${ }^{101}$ The overarching significance of this gesture should not be understated, especially since it is made even more imperative by the fact that Dodgson, as de la Mare

\footnotetext{
${ }^{101}$ Stuart Dodgson Collingwood, The Life and Letters of Lewis Carroll (Rev. C. L. Dodgson) (London: T. Fisher Unwin, 1899), p. 67.
} 
points out, generally refused to accept any correspondence or tributes addressed to him as Lewis Carroll. 'If his morning postman brought messages of joy and gratitude in a strange handwriting to the explorer of Wonderland, Dodgson retorted with a punctiliously truthful, printed, and rather frigid reply: "Mr C.L. Dodgson... neither claims nor acknowledges any connection with any pseudonym or with any book not published under his own name."' (WM, p. 26) Likewise, communications signed by Carroll - other than the occasional missives to his readership that were included in his published works - were extremely rare, to the extent that Carpenter comments on the inappropriateness of applying the title Letters of Lewis Carroll to the 1979 Morton N. Cohen edited collection. Not only, Carpenter argues, are the majority of the documents in this edition signed by Dodgson not Carroll, but it is almost impossible to detect the spirit of Lewis Carroll anywhere in [them].' (HC, p. 67)

From these details, it is plain that Dodgson desired it to be understood that there existed an important distinction between himself and Carroll as private and published personæ. There were even circumstances in which Dodgson would deny that there was any connection between himself and his alter ego. The reasons behind this transference or denial of authorship have rightly been the subject of a substantial body of study, which is diverse in its conclusions. One school of thought advocates the suggestion that Dodgson invented Carroll to provide himself with semi-anonymity, using which he could circumvent his welldocumented nervousness about putting his real name to his published Alice material. ${ }^{102}$ The fact, though, that Dodgson would have only just met Alice Liddell (the child in whose company the narrative Alice primarily took shape) at the time of Carroll's manufacture, if indeed he had met her all, renders this problematic as the sole explanation of the pseudonym's creation. Florence Becker Lennon offers an alternative and perhaps more plausible rationalization in her position that, as Dodgson grew, he felt that his existence

\footnotetext{
${ }^{102}$ See, for example, Florence Becker Lennon, Victoria Through the Looking-Glass: The Life of Lewis Carroll (New York: Simon and Schuster, 1945), hereafter FL, p. 109.
} 
became increasingly analogous to that of a genie that had escaped its bottle but wanted to return into it. (FL, p. 8) Something in the child-to-adult development of the left-handed Dodgson was not quite right, as it were, and this embedded in him a desire to stabilize a definable part of himself which could remain in literature to dwell in, investigate, and commentate upon social perceptions of childhood.

This second explanation from Lennon has much to recommend it, but it has been damaged considerably by being misappropriated by more recent critics. Peter Coveney, for example, in 'Escape," ${ }^{103}$ argues that Carroll encapsulated a nostalgic portion of Dodgson, for the purpose of providing a segregated play-area in which the author could pathetically seek the friendship of his child readers. Coveney justifies this stance from what he perceives to be the aspiringly retrogressive tone of the 1876 'An Easter Greeting to Every Child Who Loves "Alice."'104 Apparently, this document fulfils the wistfulness apparent at the end of Alice's Adventures, at the point when the narrative acknowledges the inevitability of Alice's growth into womanhood. This, in turn, facilitates Coveney depiction of Dodgson as a morose individual whose primary desire was to be left as an ageless author - Carroll - with his child friends - particularly Alice Liddell - in the safety of children's books.

Approaches to Dodgson like this one of Coveney's unfairly degrade their subject matter, as well as misread Dodgson's relationships with both his child-friends and with Carroll. By way of alternative, the research done for this thesis concludes rather that the facts of these matters should be regarded as follows. It is certainly true that Dodgson, the academic mathematician and deacon, was highly interested in children. During his life he had many young companions, with whom he loved interacting and in whose presence he took great

\footnotetext{
103 Peter Coveney, 'Escape,' in Lewis Carroll, Alice in Wonderland, ed. Donald J. Gray (New York: W.W. Norton \& Company, 1992), 327-34.

${ }^{104}$ Lewis Carroll, 'An Easter Greeting to Every Child Who Loves "Alice,"' in Lewis Carroll, Alice's Adventures in Wonderland; Through the Looking-Glass, ed. Roger Lancelyn Green (Oxford: Oxford University Press, 1998), hereafter $L C$, 248-9. This was written as an epistle from Carroll to his child readership that was included as a miniature pamphlet in early copies of The Hunting of the Snark.
} 
delight in practising two of his favourite hobbies: entertainment and photography. Concomitantly, Dodgson thought that childhood was a special phase of life and he had a tendency to mourn its passing: his interest in many of his child-friends disappeared when they entered their teenage years. None of these observations, though, even in combination, justifies the common inferences that Dodgson was any combination of a morose retrogressive, a naïve child-idealist, or a paedophile in the modern sense of the term (the latter of which is a charge laid against him with especial frequency by his critics but to support which there appears to be no evidence that is not conjectural). Indeed, as shall be seen from the Alice books, whatever part of Dodgson became inscribed in Carroll actually succeeded in creating a deeply serious (though, like Sherwood's, not always a solemn) series of literary comments on the condition of childhood, rather than a collection which obsessed over or idealized it.

\section{(ii) Reality into Fantasy: Alice Liddell vs. Carroll's Alice}

In spite of its ubiquitousness in Carroll criticism, the (misuse of the) history of Alice's Liddell's involvement in the production of Alice Adventures and Through the Looking-Glass is of sufficient contextual consequence for it to bear one more repetition here. On the 4 th July 1862, Dodgson went out rowing on the Isis with his friend Robinson Duckworth and the three Liddell sisters, Lorina, Alice, and Edith, the daughters of the Dean of Christ Church, Henry George Liddell. Throughout the course of this expedition, Dodgson constructed and related the story of what was to become, in its first written form, Alice's Adventures Under Ground, with which Alice Liddell became so enchanted that she commissioned Dodgson to write it out for her. ${ }^{105}$ An early manuscript draft of Alice's Adventures Under Ground

\footnotetext{
105 This statement should be read with the caveat that de la Mare notes the happening of a 1854 Mathematical Reading Party, referred to by Dr Paget (later Dean of Christ Church and a friend of Dodgson's), in which 'the [Alice] story... was "incubated" by Dodgson, then only twenty-two, to amuse a circle of eager youngsters of both sexes.' (WM, p. 49) Interestingly, neither de la Mare nor
} 
reached the Deanery by February 1863 , where it received the commendations of not only the little Liddells, but also Henry Kingsley, brother of Charles, who read it through one day during a visit. Following further consultation with Duckworth (who recommended John Tenniel as an illustrator for the story), and the effusive praise of George MacDonald's children, ${ }^{106}$ Dodgson was eventually convinced that his tale should be published. The earliest complete manuscript of the book arrived with Alice Liddell on 26th November 1864, with pre-publication manuscripts having been submitted to Macmillan earlier that year.

Across this developmental sequence, Taylor identifies three distinct evolutionary stages between the private aural origins of Alice's Adventures and its eventual resolution as a public published text:

It began as a story for children, the three Liddell children... Next it became a private and personal matter between Dodgson and Alice Liddell... Lastly, he rewrote the story for a public which was to consist, like Kingsley's, of "children and grown folks."

$$
(A T, \text { p. 62) }
$$

This is a convincing rendering, inasmuch as it represents implicitly the disappearance of Dodgson and the materialization of Carroll as Alice's Adventures moves from being a private to a public affair. Taylor's version is corroborated by consistent evidence that Dodgson came more and more to regard Alice's Adventures as a general children's book as its growth unfolded, rather than as a specific book for a specific child. He was, for example, genuinely moved by the commendations on his writing made by all the Liddell and MacDonald children, as opposed just to those made by Alice Liddell. He also, in the earliest of his letters

\footnotetext{
Alexander Taylor (who later commented on this episode as well) explain the anomaly of why children were attending what was presumably an academic Mathematical Reading Party, or - more importantly give any sort of detailed citations to substantiate their references to it. (Alexander L. Taylor, The White Knight: A Study of C.L. Dodgson (Lewis Carroll) (Edinburgh: Oliver \& Boyd, 1952), hereafter AT, p. 17) Beyond the comments of these two critics, no other reference to this occasion or its importance to the genesis of the Alice books has been found during the research for this thesis. Assuming, however, that there is some truth in its influence, it does serve in a small way to further belie the recurrent suggestion that Alice Liddell was the originator of Wonderland.

${ }^{106}$ Greville MacDonald records in his autobiography the splendid detail of his younger self wishing that there might be ' 60,000 volumes of [Alice's Adventures].' (Greville MacDonald, Reminiscences of a Specialist (London: George Allen \& Unwin Ltd, 1932), p. 15)
} 
to Macmillan that has been found by modern editors, made it clear that his choice of bright red as the colour for the cover of Alice's Adventures was warranted because it would be 'the most attractive to childish eyes, ${ }^{107}$ i.e., to the eyes of a multitude of children, not just those of a particular child. Finally, throughout the rest of his life, he willingly distributed copies of the Alice books to children, especially girls, to whom he took a liking. ${ }^{108}$

Thus, although Alice Liddell demonstrably provided one of the initial motivations for and one of the most important early readers of her namesake character in Carroll's books, this brief textual history suggests that we should not make the mistake of looking in them solely for some sort of biographical or realistic account of her person. Undoubtedly, indicators can be found which link both Carroll's Wonderland to Dodgson's reality and Alice Liddell to the literary Alice. However, just as Dodgson explicitly divorced himself from Carroll, so too should the Wonderland Alice be distanced from the real girl who contributed to her creation. Against this, it may be noted that at the beginning of the published Alice's Adventures, Carroll marks the book's Dodgsonian origin with a prefatory poetic retelling of his 1862 boat trip with Duckworth and the three little Liddells. This seems to bring Dodgson's reality and Carroll's narrative closer together. Also, in the 1864 manuscript edition that Dodgson gave to Alice Liddell, her presence in the text is emphasized by the inclusion of a photograph of her at the tale's end. Nevertheless, even these gestures turn out to be as much about dislocation as they are about location. The prefatory poem in Alice's Adventures

\footnotetext{
${ }^{107}$ See Charles Lutwidge Dodgson, 'Dodgson to Macmillan, November $11^{\text {th }} 1864$,' in Lewis Carroll and the House of Macmillan, ed. Morton N. Cohen \& Anita Gandolfo (Cambridge: Cambridge University Press, 1987), 35. 'Kingsley's best known children's book, The Water-Babies, was published by Macmillan in 1863, two years before Wonderland. Its format was the one that Macmillan suggested to Carroll, Carroll choosing bright red for his cover instead of Kingsley's green.' (Jo Elwyn Jones \& J. Francis Gladstone, The "Alice" Companion: A Guide to Lewis Carroll's "Alice" Books (London: Macmillan Press Ltd, 1998), p. 146) There is a hint here that Dodgson's choice of cover colour might have been motivated, in addition to its attractiveness, by a desire to distance himself from and to snipe at Kingsley's book, since Kingsley was a man that Dodgson viewed with an equal measure of respect and dislike.

${ }^{108}$ Michael Hancher, 'Alice's Audiences,' in Romanticism and Children's Literature in NineteenthCentury England, ed. James Holt McGavran (Athens, Georgia: University of Georgia Press, 1991), hereafter $J M, 190-209$ (p. 195).
} 
demonstrably embellishes on the real events which it allusively describes, ${ }^{109}$ and thereby distances itself from those events and the reality in which they occurred. Likewise, the photograph of Alice Liddell used in the 1864 manuscript captures her at the age of seven (approximately the same age as the Alice who enters Carroll's Wonderland), but Alice Liddell was over twelve years old by the time she was presented with the 1864 text. ${ }^{110}$ This means that the photograph of her included in that text was taken approximately three years before Alice's Adventures was even conceived. In short, although homage to Dodgson's friend is undoubtedly present in the spirit of these signals, they are indubitably not the actions of an author who wishes to allow her full dominion over his work.

(iii) 'I ca'n't explain myself, I'm afraid... because I'm not myself you see'

The net result of the presence in Carroll's Alice of these fracturing features - which locate her on the one hand and dislocate her on the other - is that her character is split asunder almost before it comes into textual being. Where is her identity? From what does her identity come? Is being Alice actually about anything at all? These are all questions which are asked with increasing insistence throughout Alice's progress - or, rather, her lack of it - through Wonderland. She is defined by queries about her indefinition, and these make her paradoxically freakish, paradoxically monstrous, as she tries to resolve herself in a concrete and definable persona.

\footnotetext{
${ }^{109}$ Carroll's poem begins: 'All in the golden afternoon / Full leisurely we glide.' $(L C$, p. 3) However, Martin Gardner states that 'it is with sadness I add that when a check was made in 1950 with the London meteorological office (as reported in Helmut Gernsheim's Lewis Carroll: Photographer) records indicated that the weather near Oxford on July 4, 1862, was "cool and rather wet." There is little likelihood that this is wrong. Nor is it possible that Carroll incorrectly dated his entry about the trip to Godstow, for his diary has an entry for every day of the week in question.' (Martin Gardner, in Lewis Carroll, The Annotated Alice: Alice's Adventures in Wonderland and Through the LookingGlass, ed. Martin Gardner, rev. edn (London: Penguin Books, 1970), hereafter $A A$, p. 23) Not such a golden afternoon after all then...

${ }^{110}$ U.C. Knoepflmacher, Ventures into Childland: Victorians, Fairy Tales, and Femininity (Chicago: University of Chicago Press, 1998), hereafter $U K$, p. 168.
} 
With the benefit of hindsight, almost the first action performed by Alice in Alice's Adventures causes a rift into her character. She falls asleep, leaving half of herself in her narrative's real world whilst the other half descends into a dream landscape of her subconscious' manufacture. In this dreamland, Alice's method of problem solving immediately reveals her schizophrenia, and informs the reader that self-division is a problem with which she lives on a daily basis (even in narrative reality). Consider, for instance, her response to being shrunk after consuming the contents of the DRINK ME bottle (the strength of the monosyllabic and capitalized first person imperative on the label of which demonstrates that even inanimate objects in Wonderland have more purposive foundation than Alice). She breaks down in tears but then chastises her crying self by recommending to herself that she pull herself together:

She generally gave herself very good advice (though she very seldom followed it), and sometimes she scolded herself so severely as to bring tears into her eyes: and once she remembered trying to box her own ears for having cheated herself in a game of croquet she was playing against herself, for this curious child was very fond of pretending to be two people. "But it's no use now," thought poor Alice, "to pretend to be two people! Why, there's hardly enough of me left to make one respectable person."

$$
(L C, \text { p. 15) }
$$

The narrative's use of reflexive pronouns here amplifies the fact that the very thing Alice cannot do is pull herself - her self - together. To be able to do this, she would have to have at least some idea of the things - the self - that she was pulling on, and, even at this early stage in Alice's Adventures, she does not. Alice's fondness for pretending to be more than one person continues in all the books in which she features, and points to the fact (that we already know) that she embodies several people. She contains the ghost of the Alice Liddell, who, at the age of ten, inspired the Alice stories to some degree. She contains the projected ghost of Alice Liddell's seven year old self, who was interjected into Carroll's text by the inclusion of her photograph in the manuscript edition. She contains bits of the illustrated Alice, who was 
initially drawn in sketches by Carroll before being adapted in accordance with the images of Mary Hilton Badcock that appeared in Tenniel's popular illustrations of Carroll's books. She contains bits of the sleeping narrative Alice, who is coddled by her sister on a warm river bank. She embodies the dreaming narrative Alice, who follows the White Rabbit down the hole which leads to into the fantastical underground Wonderland. She is, quite literally, all over the place, and yet, in spite of all her multiplicity, there is not enough of her to create one respectable person.

In fairness to her, this torn apart little monster does her best, in the face of tremendous odds, to consolidate herself into a locatable identity. Her problem is, though, that her taught logic - that which she has hitherto, like all children, used to define herself - makes sense in her new context neither to herself nor to the inhabitants of Wonderland. Indeed, if anything, her knowledge serves only to undermine her further. Following the reappearance of the White Rabbit, by which point Alice - through her consumption of the EAT ME cake (another notably powerful monosyllabic imperative) - has grown to massive proportions, she becomes even more concerned that she is no longer herself. Instead, she concludes that she must be one of the other children of her own age that she knows; that she must, in fact, be someone else. She becomes so convinced of this that she has to have recourse to those techniques designed to locate and establish her character's veracity that she has been taught in her real life lessons, but her attempts to do this fail twice. First, her geography is all to pot: 'London is the capital of Paris, and Paris is the capital of Rome.' $(L C$, p. 19) Second, her confused multiplication tables fall away from traditional arithmetic pedagogy, in ways that are admittedly mathematically logical but which are nevertheless highly unlikely in one so young. ${ }^{11}$ The fact that both these tests fail Alice reinforces her perception that she is

\footnotetext{
${ }^{111}$ Alice's multiplication runs $4 \times 5=12,4 \times 6=13$, etc., and her concern is that this is not a sequence that will allow her to reach 20. An increment by her of 1 to both the multiplicator and the result of each of these calculations will eventually lead to $4 \times 12=19$, and, since there is a tradition that recited multiplication tables conclude when the original operand has been multiplied by 12 , this sequence is
} 
somebody else, but this realization does not really help her because she does not know who she was in the first place. She cannot be somebody else, so to speak, without knowing who she is or who she was. By the time she reaches the hookah-smoking caterpillar, a few chapters later, the annihilation of Alice's selfhood is effectively complete:

"Who are you?" said the Caterpillar...

Alice replied, rather shyly, "I - I hardly know, Sir, just at present - at least I know who I was when I got up this morning, but I think I must have been changed several times since then."

$$
\text { (LC, pp. 40-1) }
$$

To a potentially metamorphic insect, a crisis of self resulting from physical reconfiguration is incomprehensible. Dramatic, and relatively swift physical changes, are, after all, perfectly in keeping with the life cycle of a normal caterpillar. For little girls, on the other hand, such radical alterations do not feature quite so regularly in the natural order of things, and this shows Alice's evolution in Wonderland to be a burlesque distortion of the normal processes undergone by her child counterparts. In Wonderland, instead of starting at a beginning with a view to achieving an end, Alice merely traverses from illogical dislocation to illogical dislocation. Without any sort of identity, she, quite literally, cannot make progress here.

Consequently, it becomes clear that the best way to describe Alice's presence in Wonderland is in terms of its inability to make linear progress. Initially, the story features Alice's fall downwards, in a vertical plane, into a long low hall with locked doors along its sides. The only thing which she can find to break the monotony of this scene is a glass table with a golden key on it. Unfortunately for her, with the ironic tautology that is necessarily omnipresent in a world that appears devoid of any fixed frame of reference, 'either the locks

indeed one which will not allow her to reach $20 .(M G$, p. 38) For the more academically and mathematically minded, Taylor points out that scales of notation will not allow this sequence to get to 20 either. If Alice's sequence begins on the scale 18, then $4 \times 5=12$ (one-two, equivalent to 20). If the scale is incremented by 3 with each new calculation, then $4 \times 6=13$ (one-three, equivalent to 24 on the scale 21), $4 \times 7=14$ (one-four, scale 24), $4 \times 8=15$ (one-five, scale 27), etc., until we reach 4 X $12=19$ (one-nine, scale 39). However, 4 X $13=1(10)$ (one-ten, equivalent to 52 on the scale 42 ), (AT, pp. 46-7) not 20. This sequence, therefore, also denies Alice her desired outcome. 
were too large, or the key was too small, but at any rate [the golden key] would not open any of [the doors]' (LC, p. 12). Eventually, however, Alice does find a little door with a little lock into which the key fits, and this door opens out into 'the loveliest garden you ever saw.' ( $L C$, p. 13) Irritatingly for Alice, her vertical size precludes the possibility of her immediately entering into this paradise, of her making any linear progress, and from this moment on the movement of the narrative becomes directed at Alice's desire to pass through the door. This aspiration is repeatedly thwarted, though, because she is trapped in a twodimensional world. By drinking potions and eating cakes, she can move in vertical planes, and by talking to the other inhabitants of Wonderland, she can move in lateral planes, but these activities merely serve to stall her in her current environment. Even when she does manage to reach an appropriate size to get into the idyllic garden, things fare no better for her, because she now finds herself in a place which affords her no more linear progress than the places she has just left, and which is presided over by a murderous monarch whose subjects are the epitome of duo-dimensionality, i.e., a pack of playing cards. Instead of acquiring the linear depth that she has been seeking throughout the book, Alice simply manages to swap one stasis for another. Only in a chapter entitled 'Alice's Evidence' $(L C$, p. 103) - a reference both to her interjections during the trial of the Knave of Hearts (the evidence that she gives), and the need for her to find some sort of substantiation by which to prove her existence (the evidence of herself) - can Alice engage with and ultimately assert an objective truth: 'You're nothing but a pack of cards!' $(L C$, p. 109). Only in these final moments of her tale can she fixedly identify herself for long enough to muster the objective selfhood required to facilitate her escape from Wonderland.

Looking back on Alice's Adventures, the reader knows of course that the Wonderland from which Alice escapes at the book's end is only that of a dream, even though this is 
initially a detail towards which Carroll's narrator merely hints. ${ }^{112}$ However, in spite of its subtlety, Alice's transition to her Wonderland dream world is vitally important to a correct understanding of Alice's Adventures, because it turns out to be the most significant of the many acts of dislocation undergone by Alice's character. The Alice who goes into Wonderland is a girl extracted from reality who then tries to relocate herself by repeating that which her reality has taught her. However, her lessons and facts consistently fail her, either because she is unable to deploy them correctly or because Wonderland's inhabitants are just not prepared to listen to them. In fact, the only character who comes close to understanding Alice in this context - 'the only figure other than Alice who encompasses all the others' - is the Cheshire Cat, for the simple reason that the Cat 'is aware of his own madness:'113

"But I don't want to go among mad people," Alice remarked.

"Oh, you ca'n't help that," said the Cat: "we're all mad here. I'm mad. You're mad." "How do you know I'm mad?" said Alice.

"You must be," said the Cat, "or you wouldn't have come here."

$$
\text { (LC, p. 58) }
$$

The Cheshire Cat's honesty and logic in this scene are disarming, and there is no response that Alice can give that would shake either of them. In fact, Nina Auerbach goes so far as to suggest that 'in [the Cheshire Cat's] serene acceptance of the fury within and without, his total control over his appearance and disappearance, he almost suggests a post-analytic version of the puzzled Alice.' (NA, p. 39) In other words, for Auerbach, the Cheshire Cat functions as the Wonderland embodiment of the self-knowledge that Alice so desperately wishes to achieve. Alice's failure to realize this target, however, stems, to reiterate, from her steady use in Wonderland of a reality discourse that doggedly refuses to gel with

\footnotetext{
${ }^{112}$ The opening poetic idealization of Dodgson's trip along the Isis with the little Liddells is daydreamy in tone, and the heat-induced doziness which takes over Alice at the story's beginning is gently soporific.

${ }_{113}^{13}$ Nina Auerbach, 'Alice and Wonderland: A Curious Child,' Victorian Studies, 17 (1973), 31-47, hereafter $N A$ (pp. 38-9).
} 
Wonderland's fantastical inhabitants. As a result, she is seen and not heard. Her identity is rendered void and she is made monstrous.

Thus, when W.H. Auden asserted that '[Carroll's Alice] knows that the answer to the question, "Who am I?" is really: "I am Alice Liddell, a daughter of the Dean of Christ Church," 114 he could hardly have been more wrong. Alice Liddell is, at the most, the tiniest fragment of Carroll's Alice, and Carroll's Alice certainly does not have sufficient knowledge of herself to make any sort of definitive pronouncement on the subject. Even after she eventually escapes from Wonderland, and repositions herself accurately in narrative reality with the words, 'Oh, I've had such a curious dream!' (LC, p. 110) Carroll's Alice is subsequently dismissed by her sister - who tells the little girl to run along and have her tea from her own book. Even in her narrative's reality, it seems, Alice is to be spoken down to and denied a voice. Everywhere she goes, she is marginalized, shut out, and made monstrous. And finally, although the narrator tells us that Alice muses on the wonderfulness of her dream as she runs away from her adventures in Wonderland, we who have read about them know that Alice's visions have been far from unreservedly wonderful. She has faced dangers, puzzles, crises, and a series of discourses in which she has been unable to participate, and she has had to resolve all of these against the backdrop of her disassociating self. The self-awareness of adulthood, towards which Alice appears to have been trying to move throughout Alice's Adventures, has resolutely been denied her.

\section{(iv) 'White Pawn (Alice) to play, and win'}

The Alice of Through the Looking-Glass, who was first seen in published form some seven years after her predecessor, is usually received as the diametric opposite of her earlier incarnation. After all, this later Alice is portrayed principally as a 'White Pawn [who is] to

\footnotetext{
${ }^{114}$ W.H. Auden, Forewords and Afterwords, selected by Edward Mendelson (London: Faber \& Faber, 1973), hereafter $W A$, p. 289.
} 
play, and win in eleven moves.' ( $L C$, p. 114) She is described, from these words on the opening page of her host text, as a girl with a role, an agenda, and a fixed period of time within which to fulfil the terms of both. She is called to move forwards, to move linearly, to move through the looking-glass. As James R. Kincaid puts it:

[Alice is] a figure of power in the looking-glass world and is never subject to the sorts of ominous physical threats so common in Wonderland, [and therefore] we are seldom asked to pity her... Through the Looking-Glass is, as the prefatory verses indicate, about the "'happy summer days' gone by, / And vanish'd summer glory-." But these things are gone largely because the child is... so obsessed with death, predation, and egoism that she fails altogether to recognize the beauty of the White Knight or the danger of the powerful Queens. ${ }^{115}$

If the Alice in Wonderland was an occasionally desperate and identity-deficient little girl, then Kincaid's understanding of the Looking-Glass Alice finds a young lady who has discovered enough of herself to see and grasp determinedly the light of adult identity at the end of the proverbial developmental tunnel. This new Alice wants nothing more than to be a woman and a Queen, and she is equipped with the faculties to achieve both. She, it seems, is a completely different proposition to her predecessor.

Having said which, and in apparent recognition of her younger self, the Looking-Glass Alice is nothing if not equivocal, and she again resists a reading as simplistic as Kincaid's. If, for instance, she does fail to recognize beauty or danger in the characters that surround her then her failure is, Carroll's narrator implies, the fault of the same conditioning that rendered her earlier self unable to help herself when she was put up against the new and problematic situations posed by the dreamscape of Wonderland. Again, the purpose here is not to critique the child protagonist, but rather to critique the state of her childhood. Carroll's Alice is a character whose past has consigned her to silence, and so her slightly-more-grown-up self in the Looking-Glass can hardly be blamed if, through a supposedly greedy desire to acquire the

${ }^{115}$ James R. Kincaid, 'Alice's Invasion of Wonderland', $P M L A, 88$ (1973), $92-99$ (p. 94). 
contextually monarchic powers of adulthood, she attempts to establish a voice for herself. Dodgson we know to have been a man who was enchanted by dialogue with children. It appears increasingly as though the purpose of Carroll's monstrous Alice is to demonstrate what can happen to children when they are deprived of such dialogic potential.

Now that her history has been restated, even the idea that the Looking-Glass Alice has established a sufficient sense of selfhood to possess solidified aspirations towards a future adult goal becomes somewhat prickly. Yes, her text states that she is to play and win, but she remains a chessboard pawn nevertheless. Pawns, in chess, are the front-line; the short, menial, sacrificial lambs that are disposed of in order to protect their hierarchical superiors. They are devoid of individual identity and are usually described in terms of ownership that is related to the figure that they initially cover from frontal attack, e.g., King's Pawn, Queen's Pawn, Bishop's Pawn, etc. ${ }^{116}$ They are inflexible and are able only to move forwards (albeit, occasionally on a diagonal trajectory). With their relatively small size and relatively low mobility, the chessboard to pawns is a huge and peril-filled wasteland which they must cross exposed, either to protect their seniors or - if they are fortunate enough to reach the other side - to be upgraded to some new and more powerful status.

Against such a background, the fact that circumstances have arisen in which a child can be rendered as a metonymic chess Pawn is a truly damning social indictment. Pawns are little people who are played with by bigger people, just as, Carroll suggests, adults play social or political games with the lives of children. This is a vicious environment into which Alice has been put, because it is one which, like a looking-glass, reflects the real. It is an environment that is created by an author on the attack.

However, in spite of its perils, Alice's newfound pawn status does offer her character the capacity to move linearly in a way that her Wonderland predecessor could not, and it could

\footnotetext{
${ }^{116}$ Alice, when she first makes her entrance on the Looking-Glass chessboard, becomes the White Queen's pawn. ( $L C$, p. 144)
} 
be argued that this provides a degree of positive recompense for her lowly and endangered status on the chessboard. It might well have done, at least in part, if her new location did not impose as much degradation as it does promotion on her dimensionality. Chessboards, of course, are flat: they have, at least as far as their playing characters are concerned, no vertical dimension. The only time in a chess game during which a piece can move in the vertical plane is when that piece is taken, i.e., killed, at which point it is picked up and removed from the board. Small wonder, then, that when Alice first enters Looking-Glass house she reduces the White Queen to silence by picking her up and putting her with her daughter. Similarly, Alice's later offer of comparable help to the White King leads to his falling over in horrified shock. (LC, pp. 130-33) Once again, as in Alice's Adventures, Alice's circumstances deprive her of full dimensional movement and development. It seems that, at least within the boundaries of the Carroll books in which she features, this is one aspect of Alice's growth which is to be perpetually denied her.

In addition to the above, however, it may also be deduced from Carroll's early focus on Alice's pawn existence that one of Through the Looking-Glass' central interests is in the operation of relativism between different levels of inter-character control. This may be seen, for example, in both the hierarchical organization which defines Alice's relation to her chessboard counterparts, and the implied organization between the chess pieces and the unknown players who control them. For this reason, writers like Kincaid have identified in Alice what they believe to be an invasive desire for power - control - as a feature by which to denote her as monstrous. On the chessboard, they view her as wanting nothing more than the power of monarchy, which will then be translated into all the off-board megalomania, wickedness, and desire to consume that it is possible to find in selfish adult humanity.

Alice would be a repulsive monster indeed if this were a true reading, but it is flawed by its tendency to give the Looking-Glass Alice more self-awareness than she actually has. She 
is, remember, whether in Carroll's writing or Tenniel's illustrations, nothing more than a little girl, with barely seven years of - in Carroll's terms, low-worth - knowledge to guide her actions. To combat this lack of experience, she has certainly moved beyond the confused stasis of her younger Wonderland self: the fact that the Red Queen allows Alice to substitute for Lily because 'Lily's too young to play,' ( $L C$, p. 144) confirms this, by pointing out that Alice has reached a stage of seniority that permits her to participate more actively on life's proverbial developmental chessboard. The seeming anarchy of childhood (Wonderland), in which Alice was unaware of - if not untroubled by - the adult controls which dominated her, has come to an end. Locating herself, and her ability to control, amidst the new and confusing laws of adult interaction has now become her goal (Looking-Glass). In order to do this, she must move linearly, progressively, across the Looking-Glass chessboard, and direct herself inexorably towards womanhood. She must, as we have already been told, play and win.

Auden captures precisely the spirit of this shift from Wonderland to Looking-Glass by stating that 'in Wonderland, Alice has to adjust herself to a life without laws; in LookingGlass Land, to one governed by laws to which she is unaccustomed.' (WA, p. 290) However, even if Alice did understand the rules of chess - the laws to which she is unaccustomed - her information would be of precious little help to her here, because, as Falconer Madan and others have opined, Carroll's Looking-Glass chess does not follow rules that are either fair or readily recognizable. ${ }^{117}$ By way of justifying himself against such censure, Carroll writes, in his 'Preface to Sixty-First Thousand:'118

As the chess-problem, given on a previous page, has puzzled some of my readers, it may be well to explain that it is correctly worked out, so far as the moves are

\footnotetext{
${ }^{117}$ Sidney Herbert Williams, Falconer Madan, \& Roger Lancelyn Green, The Lewis Carroll Handbook: Being a New Version of 'A Handbook of the Literature of the Rev. C.L. Dodgson' (London: Dawsons of Pall Mall, 1970), p. 62.

${ }^{118}$ The first paragraph of this 'Preface' (i.e., that which is cited here) was first included in the 'People's Edition' of Through the Looking-Glass in 1887. (LC, p. 265)
} 
concerned. The alternation of Red and White is perhaps not so strictly observed as it might be, and the "castling" of the three Queens is merely a way of saying that they entered the palace: but the "check" of the White King at move 6, the capture of the Red Knight at move 7, and the final "checkmate" of the Red King, will be found, by any one who will take the trouble to set the pieces and play the moves as directed, to be strictly in accordance with the laws of the game.

$$
(L C, \text { p. 118) }
$$

Given that Dodgson was a lover of mathematical doctrines and sequences, it would seem strange for his writing persona to doctor aspects of a game as structurally strict as chess without having some very good reason to do so. Taylor, in what amounts to a refutation of Madan's bickering on this point, offers the plausible riposte that Carroll 'was not interested in the game as a game, but in the implications of the moves:' $(A T, \mathrm{p} .101)$

In the first place it would be illogical to expect logic in a game of chess dreamed by a child. It would be still more illogical to expect a pawn which can see only a small patch of board to understand the meaning of its experiences.

$$
(A T, \text { p. 101) }
$$

In these terms, Carroll's chess game becomes an entirely realistic representation of the process of growing up. It is a game in which one starts off as a sightless pawn and in which one has to pick up the rules as one's life unfolds. The system of governance within which this happens may be neither readily recognizable nor comprehensibly fair to those who operate within it, but it nevertheless rules the board upon which one plays. Without shrewd gaming skills, involving intricate interactions with one's counterparts, it will not be long before one's piece gets taken, subsumed, and loses its identity (with all of the unknown corollaries that these actions entail). It is the task of the pieces on life's chessboard to learn about their world with sufficient speed and accuracy, to ensure that such a fate does not befall them.

To reiterate, then, the immediate problem for new chess pieces, such as Alice, is that multiple layers of control exist in their potentially hostile surroundings. Alice's experiences 
represent to her the way in which the world works and she therefore operates within their parameters, and yet part of life's complexity is that one has to operate alongside other characters with experiences that are different to one's own and who therefore operate within different parameters. Where there are no apparent rules governing the deployment of such experiences, no one thing can have more power than anything else, which gives rise to an environment like Wonderland. There, the Queen of Hearts, who is nominally Wonderland's ruler, has a predilection for head-lopping that is never carried through in practice. The Queen does not have the power necessary to control a game of croquet, let alone that which is required to preside autocratically over a system of capital punishment. However, where rules preside over or interact with experience, as they do in Through the Looking-Glass, a series of laws becomes established which differentiates between the relative powers of the environment's participants, even if those who become subject to these laws do not wholly understand them. Thus, through the Looking-Glass, power accrues to those who understand the rules of their environment, and the two Queens, whose speed and flexibility of movement decrees that they must hold more experience of their surroundings and its rules than their counterparts, possess the most power. The Red Queen, with her breadth of understanding, realizes that, in the Looking-Glass, the fundamentals of real physics are inverted. ${ }^{119}$ The White Queen, by comparison, knows that, in the Looking-Glass, memories become prophecies. $^{120}$ They both know that, in the Looking-Glass, inanimation becomes animation. They both know that, in the Looking-Glass, progress becomes regress.

\footnotetext{
119 'In our world speed is the ratio of distance to time: $\mathrm{s}=\mathrm{d} \div \mathrm{t}$. For a high speed, the distance is great and the time small; so many miles per hour. Through the Looking-glass, however, speed is the ratio of time to distance: $s=t \div d$. For a high speed the time is great and the distance small. The higher the speed, the smaller the distance covered. The faster Alice went in time, [when she was running alongside the Red Queen $(L C$, p. 144-5)] the more she stayed where she was in space.' $(A T$, p. 98)

${ }^{120}$ During a conversation between Alice and the White Queen, the Queen observes that 'it's a poor sort of memory that only works backwards.' When Alice asks her to expand on this, by enquiring what sort of things the Queen remembers best, the Queen replies, 'Oh, things that happened the week after next.' (LC, p. 175)
} 
Progress becomes regress: this is the conceit upon which turns the full significance of Though the Looking-Glass. Indeed, this is the conceit upon which turns the full significance of Alice's character as well, remembering that, in both of her books, Alice has (in a very Victorian sort of way) been obsessed with progress. In Alice's Adventures, she progresses, or rather attempts to progress, towards some sort of unknown and perhaps unknowable target. In Through the Looking-Glass, she progresses towards the fixed yet strangely undefined notion of winning a fantastical chess game. It is this notion, the notion of progress, which defines Alice as a character with a demonstrative function, because it is her progress, or her lack of it, that tears her apart - that forces her identity into disparate bits - whilst she fights to move forwards. It is in this idea that the bitterness of Carroll's societal castigation lies; in the monstrosity of the ways in which children are manipulated during their growth.

With this in mind, then, when the Looking-Glass Alice first leaves Looking-Glass House and enters into the Garden of Live Flowers, she sees a hill from the top of which she believes that she will get a better view of her surroundings (and thereby increase her experiential knowledge). She walks towards this hill but repeatedly ends up back at the place where she started. In despair, she attempts to talk to the flowers, which, since they cannot talk on the real side of the Looking-Glass, are naturally erudite after a reality-inverting journey through it. They advise her to walk in the opposite direction to that in which she intends to go, because, since going forwards in the real world is the action by which one gets somewhere, going backwards in the Looking-Glass is the action required for progress here. After Alice follows the flowers' advice, she comes face to face for the first time with the Red Queen, and, at the end of their meeting, the Queen instructs Alice to 'remember who you are.' ( $L C$, p. 147) Contextually, this instruction has three potential meanings. First, a real world interpretation finds the Queen referring to the progress already made by Alice. Alice should, quite literally, remember who she now is and what her character has already achieved in the 
books in which she has featured. Second, a Looking-Glass-internal rendering makes this an anticipatory instruction to Alice to remember the importance of her chessboard role, to progress and become a Queen (recalling that Looking-Glass memory is equivalent to real world prophecy). Thirdly, a Looking-Glass-external explanation finds the Queen telling Alice that she must remember who she is back on the other side of the mirror, i.e., a sleeping little girl, who is the narrative past and future of her currently dreaming self. Whichever shade(s) of these meanings is ascribed to the Red Queen's edict, however, its implication remains constant: Alice is now an identity with the potential to forget herself. Alice's position has shifted discernibly from that of the child protagonist who entered and left Wonderland devoid of voice and bereft of self. She now has a character. She now has individuality. She now, quite distinctly, has something to lose.

Ironically, almost immediately after her encounter with the Red Queen, Alice forgets who she is when she walks into the darkened wood of forgetfulness. She is warned by a large Gnat that the insects in this wood are without names, $(L C$, p. 152$)$ without identities, and yet she determines to proceed anyway, "'for I certainly won't go back," she thought to herself, and this was the only way to the Eighth Square.' ( $L C$, p. 155$)$ Alice determination to go forwards towards the eighth square and her projected crowning blinds her to all else, even though she has only recently been told that in order to make progress in the Looking-Glass she must go backwards. She goes into the wood, in which she meets and walks with a Fawn. Neither of them recognizes the other, either nominally or specially, until they leave the wood behind them and the Fawn realizes that Alice is a human child. To the Fawn, Alice's named identity and personality are irrelevant by comparison to the terror evoked by her species. Human children grow into human adults - the destroyers of forests and the hunters of woodland beasts - and thus humans are animals with which the Fawn wishes to have no association. It bolts. Alice, for all she appeared unmotivated to do any harm to the Fawn, is 
deemed unsafe because of what we can presume to be the Fawn's generic experience of those adult members of the little girl's species who have power over the Fawn's native environment. Alice is vilified for the actions of others, for the actions of her species, for the actions of adulthood, and yet she still determines to press forwards towards what amounts to a vindication of that vilification. In the Fawn's fear, she is warned of the dangers of what she is attempting - of growing up, of becoming a monstrous adult who manipulates, controls, and dominates - and yet she determines to do it anyway.

As Alice travels over the Looking-Glass chessboard, the other characters with whom she interacts do nothing other than substantiate the suspicion of adult humanity that is established by the Fawn. Although very few of the characters are actually human themselves, they nevertheless - almost without exception - embody caricatured versions of humanity's faults. The Walrus and the Carpenter, in the poem recited by Tweedledee, are the shadiest of social movers, as they manipulate the young Oysters to their doom. ( $L C$, pp. 162-6) Humpty Dumpty, sitting on his wall, pretends to greater intellect than he actually has, first when he appears ready to accept Alice's memorandum calculation even though it is upside-down, and second when he fabricates an interpretation of Alice's recitation of 'Jabberwocky.' ( $L C$, pp. 190-3) The Lion and the Unicorn, despite their venerable appearance in the Tenniel illustration which features Alice holding the plum-cake, ( $L C$, p. 206) are no more methodologically sophisticated in their resolution of disputations than the young Tweedle brothers. The same is true of the Red and White Knights, who, for all the apparent civility and codification of their Rules of Battle, (LC, pp. 209-11) still fight one another like two perpetually squabbling children. As experiential indicators of the rules of adulthood, two things can be learnt from these figures. First, objective good and objective evil are 
frequently hard or even impossible attributes to distinguish and ascribe. ${ }^{121}$ Second, adults fight as often as bickering youngsters, often with faux nobility and without noteworthy purpose. In other words, adults at their worst are no better than children. In fact, they are arguably worse than children, since it reflects badly on them that their relatively greater experience has not taught them to behave more positively.

Carroll's most acidic condemnation in Through the Looking-Glass on the subject of adult-child relations is raised through the characters of the two Queens (the two most powerful pieces on the chessboard and the emblem of what Alice wishes to become). As Jennifer Geer puts it:

\begin{abstract}
Alice initially believes the Red Queen's assurance that "'in the Eighth Square we shall be Queens together, and it's all feasting and fun!'”... Once Alice arrives at the Eighth Square, however, she discovers that her new role is hardly fun. The Red and White Queens are determined not to let her take her place with them as an equal. Instead, they assert their own superior status by treating her like a child, dismissing as ignorance and ill-temper all her attempts to establish her position as Queen. ${ }^{122}$
\end{abstract}

In a book which is so patently engaged in the investigation of the controlling power of adults over children - those who understand the rules vs. those who are trying to learn them - this last dismissal is the final insult to Alice. Having actively encouraged Alice towards the goal of the eighth square, the Queens become unprepared to let her ascend a level of authority which is equal with their own. To them, such a change is unacceptable because allowing a new Queen onto the board would necessarily prompt a proportional reduction in their power.

\footnotetext{
${ }^{121}$ In response to Tweedledee's poem, Alice initially favours the Walrus (because he at least feels partly sorry for the Oysters) but then moves towards the Carpenter (because he eats fewer Oysters than the Walrus). Tweedledee and Tweedledum point out, though, that both characters are selfish in their own ways, as the Walrus gets through more Oysters than the Carpenter, whilst the Carpenter still resolutely consumes as many Oysters as he can get. The net result, as Alice eventually reasons, is that the Walrus and the Carpenter are both revealed to be unpleasant characters: $(L C$, p. 167) neither is a good foil to the other's badness. Neither is more right or wrong than the other. The simple diametric polarities between good and evil that are taught in childhood are clearly not easily applicable in such a context.

${ }^{122}$ Jennifer Geer, “"All sorts of pitfalls and surprises:" Competing Views of Idealized Girlhood in Lewis Carroll's Alice Books,' Children's Literature, 31 (2003), 1-24, hereafter JG (p. 15).
} 
That Alice is ill-equipped for her crowning ${ }^{123}$ is unimportant by comparison with the fact that what has been promised to her, and what in terms of chessboard rules has become her entitlement, is now revoked. She has gone through all the machinations of the LookingGlass' adult idiocies, only to have its most powerful players refuse her that which they had previously promised. She has played but she is not being permitted to win. This last bending of the truth, this lie (in combination with all the lies that Alice has been told throughout her progress through the Looking-Glass) is the final hypocritical rule-breaking that is required to demonstrate to Alice that she cannot win in the Looking-Glass as its laws currently stand. She cannot take up her role as Queen, as woman, because the older generation will not concede its power to her. The only way in which Alice can facilitate her prescribed victory is to seize her entitlement by force and to make up her own gaming rules. Thus, as the land through the Looking-Glass degenerates around her into Wonderland-like farce, Alice uses the same technique to escape from the Looking-Glass that she did to eject herself from Wonderland. She identifies and solidifies herself - makes herself the law - by an assertive action and an objective truth: she grabs, or takes, the Red Queen, and says, 'I'll shake you into a kitten.' ( $L C$, p. 239) Moments later, Alice is holding Kitty instead of the Queen, and is back to being her true self: a conspicuously discrowned child. 'Alice takes R.Q. \& wins:' ( $L C$, p. 114) the monster asserts its authority over that which has for so long unwaveringly rejected it.

\section{(v) 'Which do you think it was?'}

In summary, the distinct dream sequences of Alice's Adventures and Through the LookingGlass offer two different (yet equally damning) appraisals of the relational crisis between

\footnotetext{
123 'Her title notwithstanding, Alice lacks the social experience to be an effective hostess, let alone a ruler. At first, she is even a little relieved when she discovers the feast has started without her; she remarks that she "'should never have known who were the right people to invite!"'... All too soon, however, the order that should have characterized a combination of state dinner and Victorian dinnerparty plunges into chaos in the face of her inexperience.' $(J G$, p. 15)
} 
childhood and adulthood. The former pits a child against an adult world which the child is too young to understand, in which instructions, advice, moralizations, and platitudes are issued confusingly and without the authority of logical explanation. The latter embeds a child in an adult world with which the child begins to interact comprehendingly, and in which rules, codifications, and power exchange are therefore more apparent (and more important). In both books, Alice is defined (and made monstrous) by her isolation, but again this is manifest in two discreet forms. Wonderland decontextualizes and disassociates her from what she knows, as a direct result of its apparent lawlessness. Alice tries to apply her learning in circumstances that doom such applications to failure, and her sense of selfhood becomes diminished with every unsuccessful attempt to locate herself via her stock of knowledge. At this early stage in her life, Alice is quite literally defined by her information, but, bereft of any stabilizing influence to guide and refine that information, her education is made worthless. It has not prepared her for such a full-frontal assault on her fragile identity. Alice's triumph in Alice's Adventures is that she is not utterly torn apart by Wonderland's machinations, which do not exist as a result of any evil that is palpably sourced in any of Wonderland's inhabitants, but simply in the fact that each little identity within Wonderland tries to operate on its own terms whilst shutting out all external interveners. Unfortunately for her, Alice is the most obvious external intervener in Carroll's Wonderland, and it is she who is most obviously shut out from it as a result.

By comparison, the unknown - and, to Alice, unknowable - rules of the land through the Looking-Glass isolate the little girl in a different way. Here, the seeds of her adult identity are established before Through the Looking-Glass even begins: her early rhetoric shows telltale signs of complex adult duplicity. ${ }^{124}$ Across this book, she makes linear progress

\footnotetext{
124 “"Oh, you wicked wicked little thing!" cried Alice, catching up the kitten, and giving it a little kiss to make it understand that it was in disgrace.' $(L C$, p. 124) Here, Alice is saying one thing when she actually means another, like the Cheshire Cat growling when it is pleased $(L C$, p. 58$)$. She is wittingly
} 
towards an idealized fun-filled notion of womanhood, guided and controlled by the experiential superiority of the two Queens (who encourage her up until the point that she becomes a direct threat to them). However, with her pawn short-sightedness, Alice remains unable to assess her Looking-Glass context in the full light of her Looking-Glass learning. She knows, for instance, almost from the moment that she enters the Looking-Glass, that it is backwards and not forwards movement - considered self-consolidation not wilful selfadvancement - that will achieve real progress here. Nevertheless, though, she still moves stubbornly forwards towards a goal for which she is unprepared. Even when she arrives at a wood within the borders of which she has been told directly that her identity will be threatened, she still - like the pawn that she is - cannot countenance the possibility of going back. Thus it is that her achievement of Looking-Glass adulthood disassembles her as quickly as if she were a fish out of water. She is simply unready for its complexities, its codifications, its trivialities, and its spitefulness. Alice needs to spend more time as a child, rather than being forced too soon into an adult mould to which she cannot adapt.

Herein lies the central criticism that develops across Carroll's two books. On the one hand, adults refuse to interact with children, leaving their progeny to infer what they will from the profusion of adult learning, whimsy, and hypocrisy with which they are bombarded. On the other, adults expect their children to become adults overnight, without wishing to deal with the responsibilities and consequences which this entails (both during and after its happening). Both procedures serve to control but not communicate with the child, and it is this communicative breakdown that renders children as monsters. Alice's particular brand of monstrosity is found not only in this but also in her existence as a metaphorical and literal everyman (everychild), whose very lack of identity simultaneously identifies her with everyone and with no-one. Since her veracity is in the majority licensed only by the discernibly adult, speech construction. 
confused teachings of her narrative's adult reality world, whilst she is resolutely silenced or displaced by the confusing contradictions of her narrative's dream worlds, she is rendered null. She becomes a character who is merely present to be pulled about as she is consistently denied the opportunity to fulfil any sort of metaphorical three-dimensional potential. Against this, it is clear that it is fundamentally incorrect to see an idealizing Dodgson as the creator of this text, for what is there to idealize in the existence of Carroll's Alice? If there was an attempt here to retrogress into a blissful world of childhood innocence, then that attempt has categorically failed. Or rather, the childhood innocence hasn't failed, but the blissful world most certainly has. This is no idealization. It is a warning, given at a distance by a covert researcher into the crises of childland, to take seriously and respectfully the condition of infancy, to not will children too soon into adulthood, and to not establish or settle adult scores - as the inhabitants of Wonderland and Looking-Glass Land try to do - through the exploitation and manipulation of a generation of genuine Alices. 


\section{CHAPTER NINE}

GEORGE MACDONALD: GOD'S SOLITARY BABY 
For all the manifold and well-documented personal differences that exist between Kingsley and Dodgson (and Carroll), it is now possible nevertheless to discern a distinct consistency of material between The Water-Babies and the Alice books. All are concerned at the state of their contemporary society, particularly with respect to that society's treatment of its children. All demonstrate their concerns through what was, in their period of children's literature, the still relatively unusual technique of drawing attention to the critical possibilities presented by analyses of the borders between real and unreal worlds. Indeed, both Kingsley and Carroll - by shifting their respective (every)child protagonists into fantasy lands - managed paradoxically to heighten the intensity of their mutual castigation of the monstrous child's situation in real Victorian Britain. If the late eighteenth- and early nineteenth-century English didactics brought with them a desire not to investigate and modify the position of children but rather to prescribe it rigidly, then Kingsley and Dodgson introduced publications which began the process of railing against such static conservative systemization.

The inheritor of this methodological mantle, proposed by The Water-Babies and seconded by the Alice books, is George MacDonald's 1871 novel, At the Back of the North Wind. ${ }^{125}$ Like its antecedents, MacDonald's book shares an interest in margins, borders, and

\footnotetext{
${ }^{125}$ This is a slight oversimplification because it glosses over a few subtleties in the inheritance sequence of Kingsley, Carroll, and MacDonald's books. The Water-Babies was undoubtedly the first of the stories to be serialized and subsequently collated into book form, but it shares more than passing similarities, according to Colin Manlove, to George MacDonald's earlier novel, Phantastes. (Colin Manlove, 'Macdonald and Kingsley: A Victorian Context,' in The Gold Thread: Essays on George MacDonald, ed. William Raeper (Edinburgh: Edinburgh University Press, 1990), 140-62 (pp. 142-3)) However, in what Manlove corroborates as a tit-for-tat authorial exchange, North Wind equally owes a debt of gratitude to The Water-Babies. Lisa Hermine Makman also points out that North Wind was initially serialized between 1868 and 1870, in the Strahan children's periodical called Good Works for the Young (of which MacDonald, during the latter half of the period in question, was the editor). (Lisa Hermine Makman, 'Child's Work is Child Play: The Value of George MacDonald's Diamond,' Children's Literature Association Quarterly, 24.3 (1999), 119-29, hereafter $L M$ (p. 129)) This dates the initial release of North Wind before that of Carroll's Through the Looking-Glass, even though the two books were eventually published alongside one another as single volumes in 1871. This intertextuality does not detract from the overarching point that Kingsley, Carroll, and MacDonald between them heralded in an identifiably new movement in the canon of English children's literature. Nevertheless, it does allude to a rich interrelation between these authors, whether or not they were immediately aware of it.
} 
communicative difficulties, as a result of which its child protagonist, Diamond, like Tom and

Alice, becomes every bit the little monster. Furthermore, like The Water-Babies, North Wind also attempts to engage a target audience that appears to be split between what we may presume to be reading adults and listening children. ${ }^{126}$ Allowing, however, for these likenesses, MacDonald's text simultaneously makes pronounced moves away from The Water-Babies and the Alice books, by concerning itself directly with neither the evolution nor the growth of its alienated young protagonist, nor even with his interaction with the fantastical North Wind (although all of these remain noteworthy features which will require consideration here). Rather, as will be shown, North Wind's focus is to elevate Diamond's significance in relation to his narrative's society beyond that of the Kingsleyan and Carrollian everychild. By doing this, Diamond achieves an application that is far more specialized, arguably more important, and undoubtedly more monstrous than those of his predecessors.

\section{(i) Children That Disturb: The Trusting Solitudes}

On a cursory inspection, MacDonald's Diamond does not appear to be a character who is beset by crises of difference and marginalization. Certainly, he is not from a wealthy background, but he is neither alone nor unhappy with his lot. He appreciates the warmth of his meagre bed in his family's hayloft, the fun that he can have with simple toys ('a broken chair, a three legged stool, and a blanket ${ }^{127}$ ), and the unconditional if uncomprehending love

\footnotetext{
${ }^{126}$ Roderick McGillis states that the research of those writers who contribute to his For the Childlike essay collection demonstrates consistently that MacDonald's nominal literature for children frequently assumes a mature audience. (Roderick McGillis, 'Introduction,' in For the Childlike: George MacDonald's Fantasies for Children, ed. Roderick McGillis (Metuchen, N.J. \& London: The Children's Literature Association \& The Scarecrow Press, Inc., 1992), 1-17 (p. 6)) Lending credence to this, in the case of North Wind, is the tale's opening paragraph and its mention of Herodotus. It is surely unlikely, after all, that an author who was writing a book for a solely youthful audience would choose a Greek Historian as the vehicle by which to locate the beginning of his text.

${ }^{127}$ George MacDonald, At the Back of the North Wind, in George MacDonald, At the Back of the North Wind / The Princess and The Goblin / The Princess and Curdie (London: Octopus Books, 1979), hereafter $G M, 5-292$, hereafter $N W$ (p. 13).
} 
of his devoted parents. In fact, the only obviously peculiar feature about Diamond - other, perhaps, than his angelically placid temperament - is his unusual name, which the narrative explains by the fact that Diamond's father, Joseph (who is a coachman), named his little boy after a favourite horse. ( $N W$, p. 11) Although this may seem a slightly odd reason to choose a name for one's son, MacDonald turns it into the most touching of gestures that reinforces the sense that Diamond dwells in a loving and appreciative familial community. Not only does Diamond's name imply his father's awareness of the boy's material value (like that of a diamond, or of a working horse to a coachman) but it also points towards the boy's spiritual and personal value too (inasmuch as he is named after a creature that Joseph clearly considers to be the most beloved and precious of companions).

However, the narrative's description of Diamond's first interaction with the apparentlyfantastical North Wind subtly suggests that there is more complexity to this little boy's existence than is given away by his uncomplicatedly beautiful initial representation. Consider their opening exchange, from the point when North Wind's voice accuses Diamond of using a strike of hay to stop up her window (a little hole into Diamond's bed, through which the wind blows in on him during the night). (NW, p. 14) Diamond refutes this allegation on the grounds that windows are things through which one looks out. By implication, since his bed is indoors, a hole in it from the outside looks in not out, and therefore cannot be a window. North Wind, however, on the other side of the wall that separates the two speakers, sees things differently, because indoors for her is like outdoors for Diamond. From her perspective, a hole through the side of Diamond's bed looks outwards from her indoors, and can thus function as a more than satisfactory window. Stalemate ensues, because both protagonists believe themselves to be in the same position, i.e., on the inside looking out. A mutual lack of understanding keeps the characters apart and this must be overcome before any progress can be made in their relationship. 
To facilitate this advancement, and trusting North Wind's assertion that he will not be disadvantaged by his decision, Diamond eventually agrees to remove his hay stopper from her supposed window. This action removes the physical barrier between the two, and allows North Wind to enter into Diamond's hayloft bedroom. Very little is actually achieved by this, though, because the cold of North Wind's presence makes Diamond throw up another physical barrier - his bed-clothes - to protect himself from her. The original impasse, of apparent mutual incomprehension, is restored and then reiterated by North Wind's decision to poke fun at her little companion:

"What is your name little boy?" [the voice] asked.

"Diamond," answered Diamond, under the bed-clothes.

"What a funny name!"

"It's a very nice name," returned its owner.

$(N W$, p. 16)

The problem which starts here is exactly the same as it was earlier in the case of the window, and it arises because both characters appear to understand different things by the noun diamond. For Diamond, the only thing other than himself with which he associates his name is Old Diamond ('a great and good horse'), whereas, for North Wind, 'diamond is a useless thing rather.' ( $N W$, p. 17) In an ironic trade-off, Diamond then manages to commit an equal injustice against North Wind's name by referring to her unknowingly as 'Mr. North Wind.' ( $N W$, p. 17) Hiding as he is under his bed-clothes, he does not have the knowledge to right his gender error. $M s$ North Wind responds by persuading Diamond, after some rather angry coaxing, that the only way in which he is going to be able to correct himself is by dropping the barrier that remains between him and his new acquaintance. Eventually, and rather nervously, he does so, and with this final surmounting of the initial barricades between these two characters, a fuller dialogue of mutual comprehension can resultantly ensue between them. 
These early symbols of obstruction and blockage in relation to Diamond draw attention to the fact that - although he is an appreciative, playful, and well-loved little boy - he is also, peculiarly and paradoxically, ever on the cusp of being isolated. In fact, as MacDonald's story unfolds, it becomes clear that Diamond's relationship with North Wind is the truest approximation to a reciprocal friendship that he is ever going to get in the confines of this narrative. Again, this is not to say that Diamond is uncared for or disliked by his counterparts, since there are very few other characters in the book that have even a single harsh word to say about him. Yet, for all the fondness with which Diamond is treated, he is also handled with care, either in the form of the tender molly-coddling that is favoured by his mother, Martha, or in the more general wariness that is used around him by those who know him less intimately.

It is the latter of these two treatments which is contextually the most interesting, because the wariness with which some behave towards Diamond tends occasionally towards fearfulness. This trepidation arises because Diamond, as far as the characters around him are concerned, disturbs the border between reality and unreality, whilst himself remaining undisturbed. As is shown in the scenes already described, North Wind (fantasy) blows in to the homely domesticity of Diamond's bedroom, with no real preparation or compensation for her presence. Fantasy directly invades reality, and the factor which permits it to do so is Diamond (because he hears North Wind, sees North Wind, and tries to understand North Wind). He literally accepts unreality (North Wind) into his reality, but, in terms of those around him, this sort of relationship with the other and the beyond makes him inexplicable, unacceptable, and monstrous. It makes him a character who is to be handled with care; around whom one needs to be wary.

The pattern established by this early border-blending is one which is methodologically significant throughout North Wind, because, as Robert Lee Wolff puts it: 
We are here not dealing with an explicit transfer from the world of reality to the world of dreams, as in Phantastes... [which is a purely dream narrative]. For adults, At the Back of the North Wind is like Hoffmann's Golden Pot: as if falling asleep, almost without warning, we pass from one world to the other, and at times the two worlds are fused. $^{128}$

So, unlike The Water-Babies and the Alice books, during which the reader can detect a relatively clean-cut shift between reality and fantasy (albeit, in Alice's Adventures, with the benefit of hindsight), Diamond's transitions between these two modes are usually much less obviously defined. Indeed, during the overwhelming majority of North Wind, it is debatable whether he actually makes any such transitions at all. After all, Diamond does not perceive there to be any radical difference between his daily existence with his parents and his alternative existence with North Wind. He does not link the presence of North Wind with his descent into delirium or illness (in the way that the narrative increasingly encourages the reader to do as the text progresses). Rather, he simply accepts her as an integral and truthful part of his everyday life. When Diamond hears the voice of North Wind for the very first time, he does not doubt its veracity and he is not frightened by it, 'for he had not yet learnt how to be [afraid]; so he sat up and hearkened.'( $N W$, p. 14) Diamond is defined by this causal link: an unknown voice does not frighten him, because he does not yet know how to be frightened, and thus he is free to listen to it without encumbrance. He trusts and believes simply, like the child that he is:

If Diamond had been a little older, and had supposed himself a good deal wiser, he would have thought the lady was joking. But he was not older, and did not fancy himself wiser, and therefore understood her well enough. Again he stretched out his arms.

$$
\text { (NW, p. 19) }
$$

\footnotetext{
${ }^{128}$ Robert Lee Wolff, The Golden Key: A Study of the Fictions of George MacDonald (New Haven: Yale University Press, 1961), hereafter $R W$, p. 148.
} 
Thus, Diamond's understanding of North Wind stems from the facts that he is neither old nor has any delusions of wisdom beyond his station. The characters that surround him have not these gifts because they are not as young as he, noting that age here is not necessarily an attribute which is described by the number of years for which one has been alive: '[Nanny] called [Diamond] a kid, but she was not really a month older than he was; only she had had to work for her bread, and that so soon makes people older.' ( $N W$, p. 45) Initially, Nanny does not believe Diamond when he tells her about North Wind, and she admonishes him for telling what she presumes to be untruths. $(N W$, p. 47) Yet Diamond knows and believes in North Wind just as well as he knows and believes in Nanny, if not better. Denying one would be as bad and as false for him as denying the other. Accordingly, Diamond is special and different because he tells of truths that no-one else can see, which is acknowledged by MacDonald's narrative but not by any of its other human characters. North Wind is the only person who can comprehend Diamond fully because she is the only person who knows him as the little boy who moves in and out of the nominal unreality of his fantastical relationship with her, without - and this is crucial - ever actually leaving reality. North Wind, a supposedly imaginary figure, offers Diamond the communicative reciprocity which he is unable to attain with any of his counterparts in the real world. She does so because, like a child, he trusts in her completely.

These abilities to listen, trust, and understand, which allow some to see more in their surroundings than others do, are subjects that MacDonald investigated frequently. In one of his later fairy novels, The Princess and the Goblin, MacDonald details the story of a young princess named Irene. Irene is unlike Diamond, inasmuch as she is evidently located in a fantasy world of kingly castles and underground goblins, but she shares Diamond's crisis of seeing things in her world which other characters cannot. One day, at the top of a tower in the castle in which Irene lives, she stumbles upon the dwelling place of her great-great- 
grandmother, but, when she later tells her nurse, Lootie, about this discovery, Lootie chastises the little princess for talking nonsense. Indeed, when Irene goes back the next day to try to find the stairwell that leads to her grandmother's rooms, she fails in her attempts to do so:

Her failure to find the old lady not only disappointed her, but made her very thoughtful. Sometimes she came almost to the nurse's opinion that she had dreamed all about her; but that fancy never lasted very long. She wondered much whether she should ever see her again, and thought it very sad not to have been able to find her when she particularly wanted her. She resolved to say nothing more to her nurse on the subject, seeing it was so little in her power to prove her words. ${ }^{129}$

Irene's response to this disappointment is striking. Instead of doubting the evidence of her eyes and memory, as a more cynical character might have done, she fully accepts that on one day she was able to find her grandmother whereas on the next day she is not. She believes that what she saw was true, and is happily content (although notably not self-satisfied) in that knowledge. This is not the end of the matter, however, because, when Irene later takes her friend Curdie to meet her grandmother, she becomes confronted by a much more immediate attack on her credibility:

"Don't you see the lovely fire of roses - white ones amongst them this time?" asked Irene... "Nor the blue bed? Nor the rose-coloured counterpane? Nor the beautiful light, like the moon, hanging from the roof?"

"You're making a game of me, your royal highness; and after what we have come through together this day, I don't think it is kind of you," said Curdie, feeling very much hurt.

"Then what do you see?" asked Irene, who perceived at once that for her not to believe him was at least as bad as for him not to believe her.

"I see a big, bare, garret-room - like the one in mother's cottage, only big enough to take the cottage itself in, and leave a good margin all round," answered Curdie... "I see a tub, and a heap of musty straw, and a withered apple, and a ray of sunlight coming through a hole in the middle of the roof, and shining on your head, and making all the place look a curious dusky brown. I think you had better drop it, princess, and go down to the nursery, like a good girl."

$$
(P G, \text { p. 417) }
$$

\footnotetext{
${ }^{129}$ George MacDonald, The Princess and the Goblin, in $G M, 295-458$, hereafter $P G$ (p. 320).
} 
Here, the gulf between what Irene can see and what Curdie can see (and therefore the gulf between Irene and Curdie) is plain for the princess to realize. Curdie can stand in the presence of Irene's grandmother, and not even perceive the old lady's possessions, let alone the old lady herself. Under the circumstances, all that Irene can do is let Curdie go, on her grandmother's advice that Curdie will only acquire more complete vision - the vision required to see Irene's grandmother - in the fullness of time.

In summary, Irene can see her great-great-grandmother because she is prepared to listen, trust, and believe in her, even in the face of the incredulity and ridicule of her peers. These abilities, in an otherwise apparently atheistic world, are measures of Irene's successful spiritual progress. Dieter Petzold distinguishes Irene above Curdie in Irene's combination of maturity and education (where "'maturation" is the natural development of a personality which involves also cultural factors, [and "education" is] a gently guiding support of this process'). ${ }^{130}$ Diamond's position with respect to North Wind is identical that of Irene with respect to her grandmother. Both children unquestioningly accept the truth and educative power of their respective (maternalistic) guardians, and yet neither child can successfully communicate the full veracity of these guardians' existences to the normal characters that surround them. A barrier - of an unsettling perceived combination of untruth, illness, and perhaps even incomprehensible power - exists between Irene and Diamond on the one hand, and those with whom they interact on the other. It is this barrier, more than anything else, which characterizes these two children as solitaries. It is this barrier that makes them so disturbing.

${ }^{130}$ Dieter Petzold, 'Maturation and Education in George MacDonald's Fairy Tales,' North Wind, 12 (1993), 10-24. 
To focus again on North Wind, there are two crucial distinctions between North Wind and Irene's grandmother which are important for the ways in which they eventually contribute to Diamond's character. Firstly, North Wind's personality is problematically dual in a way that the personality of Irene's grandmother is not. Secondly, North Wind is a means to an end the country at her back - rather than an end in and of herself. Diamond moves towards the second of these, towards being at the back of the North Wind, throughout North Wind's first half, and it is through his participation in this journey that he is enabled to become palpably more than the beautiful but distanced child that he is at the story's beginning. After the fulfilment of this developmental sequence, Diamond's monstrous alienation and detachment from those around him undoubtedly remain, but the significance of these traits is effectively reduced by the new demonstrative capacity that his character concomitantly acquires. Ultimately, it is not his journey here but what he achieves at the end of it that is important. This chapter will now focus upon the ramifications of this, and identify the ways in which it facilitates Diamond's progress through and to divergent forms of monstrosity.

To begin this analysis, we must start by considering the construction and the consequences of North Wind's doubleness, about both of which Knoepflmacher, in his Ventures into Childland, has written compelling accounts. According to Knoepflmacher, North Wind's role is trapped between the polar extremes of aggressive destructor and maternal protector, and Diamond - the same Diamond who, in the narrative's description of his first contact with North Wind, is identified as being without fear - learns to be afraid of her as he does his best to rationalize the co-existence of these opposing composites inside one entity. (UK, pp. 237-9) Traces of this can first be seen when, on one of their early trips together, North Wind explains to Diamond that she has to take upon herself the form of a 
vicious wolf in order to make herself visible to a drunkard nurse who is calling a child in her charge by bad names:

At the foot of the stair North Wind stood still, and Diamond, hearing a great growl, started in terror, and there, instead of North Wind, was a huge wolf by his side. He let go his hold in dismay, and the wolf bounded up the stair. The windows of the house rattled and shook as if guns were firing, and the sound of a great fall came from above.

$(N W$, p. 35)

Although the principle of this action is arguably maternal, since it is done to protect an innocent child, its execution is vicious and animalistic, in spite of North Wind's subsequent protestations that she does no physical harm to either the woman or the baby. This scene leaves Diamond in a quandary, because he feels after it that he no longer really knows his friend. ( $N W$, p. 36) Can he still regard her as a gentle mother or will she forever be a snarling wolf? Can she, simultaneously, be both?

A yet more obvious occasion when North Wind's duality causes similar problems for Diamond comes at the end of MacDonald's fifth chapter, when Martha tells her son that he looks ill and that he had better go to bed. The little boy assents immediately, because he is good and obeys his mother, and, after gazing at the sky for a moment or two, he falls into a troubled sleep. $(N W$, p. 56$) \mathrm{He}$ is woken in the middle of the night by a storm raging outside, and is called by North Wind (the cause of the squall) to come out to be with her. Straight away, this scene is made uneasy, because North Wind's instructions are in direct opposition to both the imperative (go to bed) and the implication (get some rest) of Martha's. North Wind, the maternally tender fantasy figure, has her role destabilized as she demands strenuous action from a child who is nominally weak and sickly. Nevertheless, because Diamond trusts in North Wind, he agrees to go with her, but, in the process of her lifting him from out of his bed, he becomes afraid: 
The hand felt its way up his arm, and, grasping it gently and strongly above the elbow, lifted Diamond from his bed. The moment he was through the hole in the roof, all the winds of heaven seemed to lay hold upon him, and buffet him hither and thither. His hair blew one way, his night-gown another, his legs threatened to float from under him, and his head to grow dizzy with the swiftness of the invisible assailant. Cowering he clung with his other hand to the huge hand which held his arm, and fear invaded his heart.

$(N W$, p. 58)

Paradoxically, Diamond is being scared here by that which he concurrently loves, and North Wind is not frightening him as a result of any malicious intent but simply because she is doing what she does (i.e., being North Wind). She is the winds of heaven and she is his invisible assailant. It is she that is buffeting him. Diamond calls out in terror, but his voice is muted by the racket around him:

[His words] couldn't get out at all, but were torn away and strangled. And yet North Wind heard them, and in her answer it seemed to Diamond that just because she was so big and could not help it, and just because her ear and her mouth must seem to him so dreadfully far away, she spoke to him more tenderly and graciously than ever before. Her voice was like the bass of a deep organ, without the groan in it; like the most delicate of violin tones without the wail in it; like the most glorious of trumpetejaculations without the defiance in it; like the sound of falling water without the clatter and clash in it: it was like all of them and neither of them - all of them without their faults, each of them without its peculiarity: after all, it was more like his mother's voice than anything else in the world.

$(N W$, p. 58)

These last phrases, which align North Wind's voice with that of Martha (in spite of all the terrors that Diamond has just undergone), intriguingly echo one of the first phrases used by MacDonald's narrator to describe North Wind: '[Diamond] thought [her voice] sounded a little like his mother's.' ( $N W$, p. 16) Partly, this is a comfort to Diamond, but, in some senses, it adds depth to his fright by associating the homely likeness of Martha's speech with the cacophony of North Wind's storm. Diamond addresses this fear by trying to separate the North Wind he loves from the North Wind that scares him, a policy which seems particularly sensible when she goes on to validate such dichotomous assessments of herself by saying that 
she is going to hold Diamond defensively in one arm whilst fulfilling her duty as North Wind by sinking a ship with the other. Diamond takes this to mean that North Wind is literally going to be good on the one hand and cruel on the other - literally bipartite - but she then contradicts this assumption by drawing attention to its illogicality:

"Ah! But which is me? I can't be two mes, you know."

"No. Nobody can be two mes."

"Well, which me is me?"

"Now I must think. There looks to be two."

"Yes. That's the very point. - You can't be knowing the thing you don't know, can you?"

"No."

"Which me do you know?"

"The kindest, goodest, best me in the world," answered Diamond, clinging to North Wind.

$(N W$, p. 61)

At the end of this exchange, Diamond claims to believe in, and indeed is clinging desperately to, what he perceives to be the best, the maternal, part of North Wind, whilst being faced with the imminent prospect of another presentation of her destructive animalistic capabilities. Again, though, she pushes him to rationalize her as one entity by suggesting that, if she were bipartite, what he regards as her kinder side could actually be just a cynical façade that will allow her wicked side the opportunity to be crueller still at some later stage. Such contrary pressure from his fantasy mother-surrogate is beyond Diamond's ken and he crumbles into verbal acceptance of her as a single, though complex, being that he cannot help but adore:

No, no, dear North Wind; I can't believe that. I don't believe it. I won't believe it. That would kill me. I love you, and you must love me, else how did I come to love you? How could you know how to put on such a beautiful face if you did not love me and the rest? No. You may sink as many ships as you like, and I won't say another word. I can't say I shall like to see it, you know.

$(N W$, p. 62)

As this scene concludes, it is quite clear that North Wind has not actually won over Diamond to her way of thinking. The boy's innocent mind still cannot focus upon and resolve North 
Wind as one body which delivers simultaneously what he recognizes as the disparate actions of love and destruction. This occasion, in fact, manifests North Wind's bipolarity to Diamond to such an extent that, no matter how much he still loves her, she - of herself - will never again be wholly satisfactory to him in the context of their previous mother-child relationship. She has destroyed his false image of her as an omnipotent, all-loving, and understanding parent. She is now too split, too apart, and too inconsistent.

The destruction of this image is an essential contributor to Diamond's development alongside North Wind, for it proves that, no matter how loving and powerful she may be, she nevertheless remains bound by the same flaws, restrictions, and hypocrisies that delineate the reality in which she and Diamond exist. She may look beautiful for some of the time, and she may even behave beautifully for some of the time, but there remains a primality and a distortion about her which inevitably define her existence. At this point, and in this realization, the power of Diamond's monstrous other-worldly qualities (innocence, love, trust, carefulness) finally exceeds that of North Wind. He demonstrates a child-like love for her even though he now knows her to be as much of a destroyer as she is a defender. He remains trusting of her and dedicated to her even though he knows her to be flawed. However, the relationship between them is now so unsettled that they can no longer proceed alongside one another in the manner that they have done hitherto. Diamond has been destabilized and he needs now to move beyond North Wind to discover an equilibrium that she can no longer provide for him.

Or, to put it another way, Diamond needs to move through North Wind to access directly those qualities which support her, define her, and create her. He has got to pass the boundaries of her real world self, into the abstract fantastical core of her spiritual being. Having said which, the outward and inward journeys made by Diamond through North Wind turn out to be of far greater significance than the time which he spends at her back (about 
which the narrator remains determinedly ambivalent. ( $N W, \mathrm{p} .91)$ ) Once again, Knoepflmacher is convincing in his description of this process, as he represents Diamond's entry into the country at the back of North Wind (NW, pp. 89-90) as a reunion with the mother-figure:

MacDonald makes it clear that North Wind considers [Diamond's] entry into her body as still another test of the immensity of Diamond's unbounded and unquestioning love a love she more than ever finds difficult to requite in the manner of a living, biological mother. When the boy mistakes her paralysis for indifference, he reproaches her much as a small child might reproach a dying parent for failing to return its hungry passion. North Wind's reply suggests that his compulsive need for reciprocity may be satisfied after he adopts her own condition. He, too, will have to fade, dissolve, and blend with her before moving on.

$$
(U K, \text { p. 246) }
$$

Knoepflmacher is absolutely right to describe North Wind, on this occasion, as a dying parent, since the expedition which Diamond fulfils by walking through her is one which effectively forces her out of MacDonald's book. After the boy's recapitulation with her (in the theological sense, of establishing a union or collating things together into a single body), North Wind is no longer needed so much in the text because those parts of her that are essential - of her essence - become relocated in Diamond. Evidence of this is seen when Diamond, whilst in the country at the back of North Wind, expresses a desire to go home, as a result of a combination of general homesickness and, far more importantly, because one day in a vision 'he saw his mother crying.' ( $N W$, p. 95$)$ Diamond wants to go back home because he wants to deliver parental comfort to his parent. His mother, it is implied, now needs him as much as he needs her, if not more. Yes, Diamond is homesick like a child, but he has a new instinct - acquired from his melding with North Wind - to protect and comfort like a parent.

Thus, when Diamond returns from the back of the North Wind, his role is realigned into one that parallels that of his former friend. The journey that he has been on and the country 
that he found at North Wind's back both become less important in comparison to the fact that his equilibrium is re-established by his assimilation of many of those traits that he adored in North Wind's earlier treatment of him. Note that North Wind's first words to Diamond on his return gesture partly to her original maternal role, as a mother might speak softly to her newborn child, but hint as well at a new weight of years in her, as that of an aged lady who wishes for the warmth and support of a vitalizing younger presence:

“"How very alive you are, child!" she murmured. "Come nearer to me." $(N W$, p. 97)

Even to North Wind, it seems, Diamond comes back as a character renewed, who returns to the real world - as Knoepflmacher rightly has it - like the epitome of Wordsworth's child with its trail of glorious clouds. (UK, p. 248) Unlike Wordsworth's child, however, Diamond is not destined to fade into the shadows of adulthood, because, for Diamond, the essential parts of his growth and evolution are now complete. He is now called upon to perform the new and unique collective role of child and parent. ${ }^{131}$

Of course, such an unusual function hardly serves to make Diamond less monstrous than he was before. In fact, it does quite the reverse, because the child is now in a more-or-less unprecedented position without even the remotest chance of finding real-world empathy. Significantly, though, empathy is now less important to Diamond than his new ability to empathize, because - having been to the back of North Wind - he now carries with him enough of her spiritual presence to ensure that his own empathetic needs are fulfilled. As Makman puts it, 'after [Diamond] travels to the back of the north wind... he returns to the human world to do the "work" of a human angel.' (LM, p 120) In other words, Diamond's renewed self is afforded manifold opportunities to make himself useful in ways that he was

\footnotetext{
131 'For Wordsworth, childhood is bound by time; it passes. For MacDonald, the opposite is true; childhood is a state of being which everyone must aspire to.' (Roderick McGillis, 'Childhood and Growth: George MacDonald and William Wordsworth,' in $J M, 160-67$ (p. 152))
} 
not before. No longer is Diamond the little boy who answered 'I don't know what I do do... Nothing, I suppose' ( $N W$, p. 43) to Nanny's queries about his occupation. Instead, he can now avail himself of every chance to aid the clean-up operation in the wake of what North Wind earlier described as 'those careless, greedy, untidy children [i.e., adults, who] make [the world] in such a mess.' ( $N W$, p. 38) In his family home, Diamond takes on the role of both father (as a coachman) and mother (as a protector and nurse for the smaller children). In the wider world, he enriches and disciplines the lives of ailing adults and children alike, noticeably filling the roles that North Wind would once have taken upon herself.

Exemplifying the widened sphere of influence across which Diamond's new spiritual beneficence impacts is the tale, in North Wind's eighteenth chapter, of Diamond's involvement with the drunken cabman. Here, Diamond wakes in the night, hears a baby crying, and goes to investigate the cause of the noise (because he is 'just as much one of God's messengers as if he had been an angel with a flaming sword, going out to fight the devil'). (NW, pp. 142-3) He enters the house of the drunken cabman (who plainly neglects both his wife and his child), picks up the crying infant from its cot and begins to sing to it. After a while, Diamond begins to speak to the baby in a semi-soliloquy, exhorting against the evils of alcohol:

But your daddy will drink the nasty stuff, poor man! I wish he wouldn't, for it makes mammy cross with him, and no wonder! And then when mammy's cross, he's crosser, and there's nobody in the house to take care of them but baby; and you do take care of them, baby - don't you, baby? I know you do. Babies always take care of their fathers and mothers - don't they, baby? That's what they come for - isn't it, baby?

$(N W$, pp. 145-6)

Having thus ensured not only the propagation of his teetotalist message, but also that of his now fully-fledged understanding of the importance of children and youthfulness, Diamond departs, leaving the just-about-conscious cabman to ponder whether or not an angel has just graced his house with its presence. This scene is utterly reminiscent of North Wind's earlier 
lupine lesson to the naughty alcoholic nurse, except that where North Wind employed guttural bestiality to ram home her message, Diamond instead makes his point through the tender nurturing of an innocent baby. North Wind's role has thus been enmeshed in Diamond's profound emotional and moral responsiveness. The drunken cabman, one might say, gets literally the best of both worlds.

From this example, it is plain that, although Diamond is still as alien as ever he was to the working-class Victorian society in which he dwells, his presence is now of sufficient power to deliver often deeply spiritual messages to those with whom he interacts. These communications may not necessarily come in a form which their recipients can immediately recognize or rationalize, but this is not surprising since they originate from an authority (enabled during Diamond's journey to the back of North Wind) which even MacDonald's narrator claims an inability to describe. $(N W$, p. 91$)$ In the achievement of this, Diamond has actually managed to become even more like the inexplicably sublime Wordsworthian child than either Knoepflmacher or McGillis credit. Indeed, Diamond's alienation becomes increasingly defined in terms of his having become a poetic component, even a poet, inside the realist world of MacDonald's fictional narrative. North Wind's description of what it is to be a poet sharply personifies the rejuvenated Diamond ('a poet is a man who is glad of something, and tries to make other people glad of it too' $(N W, \mathrm{p} .55))$, and it is no coincidence that Diamond is forever dreaming about, singing, and reciting verse. ${ }^{132}$ Note also that Durante - a figure who the narrator implies not only had an excellent grasp of poetic description, (NW, pp. 91-2) but whose very name is a thinly veiled homage to Dante - is one

\footnotetext{
${ }^{132}$ When Diamond and his mother visit the seaside, in chapter thirteen, they see a little book fluttering in the breeze. They pick it up and discover that the book contains nursery rhymes, which Diamond asks Martha to read to him. She assents to his request, even though she finds the poems nonsensical ('So his mother thought it might amuse him, though she couldn't find any sense in it. She never thought he might understand it, although she could not.' ( $N W$, p. 110)) Eventually, Martha gives up on her oratory, declaring that '[she believes] it would go on for ever,' $(N W$, p. 116) at which words Diamond has a flash-back to the river at the back of North Wind which did indeed go on forever. Again, Diamond's mind is operating on a level which Martha cannot comprehend. He identifies with the verse in a way which she cannot.
} 
of the few other people who has successfully made the journey to North Wind's back. The presence of poeticness is clearly an important factor here.

Leona W. Fisher agrees with the gist of this assessment, ${ }^{133}$ but pushes it further by arguing that:

Language is, in fact, inadequate to both Diamond's experience and MacDonald's intentions. He therefore must continually make distinctions between what is and what can be described, between essences and their verbal approximation... Diamond's adventure at the back of the north wind is itself inexpressible.

$$
(L F, \text { p. 41) }
$$

In a context such as this, a child such as Diamond who cannot yet read but who can nonetheless - as he explains to Mr Raymond - create mysterious, almost unspeakable, songs, is an exceptional specimen to behold:

"I make songs myself. They're awfully silly, but they please baby, and that's all they're meant for[," said Diamond.]

"Couldn't you let me hear one of them now?" said Mr. Raymond.

"No sir, I couldn't. I forget them as soon as I've done with them. Besides, I couldn't make a line without baby on my knee. We make them together, you know. They're just as much baby's as mine. It's he that pulls them out of me."

"I suspect the child's a genius," said the poet to himself, "and that's what makes people think him silly."

Now if any of my child readers want to know what a genius is - shall I try to tell them, or shall I not? I will give them one very short answer: it means one who understands things without any other body telling him what they mean. God makes a few such now and then to teach the rest of us.

$$
(N W, \text { p. 170) }
$$

This short conversation tells all that is needed to finalize an assessment of Diamond's character. He has become a poetic song-smith, whose artistry arises from an impulse to please and augment the lives of others. He cannot be compromised by commodification because his poesy arises entirely from his capacity to achieve a pacifying or educative reciprocity with his subject. His talent is recognized (though probably not fully understood)

133 Leona W. Fisher, 'Mystical Fantasy for Children: Silence and Community,' The Lion and the Unicorn, 14 (1990), 37-57, hereafter $L F$ (pp. 40-2). 
by Mr Raymond, further confirming Diamond's status as a poet (since Mr Raymond is a poet himself). His comprehension and empathy are - in the context of North Wind's latter half unsurpassed. Diamond may not be understood but he nevertheless understands. His messages, wrapped up in literal and metaphorical poetry, may rarely fall on comprehending ears, but their impact - in a way which, once again, the narrator refuses to qualify in words remains indubitably profound.

\section{(iv) God's Baby}

For all one must take care to not over- or mis-allegorize any text, it is now surely undeniable that at least part of MacDonald's narrative intention in At the Back of the North Wind must be to analogize Diamond with Jesus. The situation of the contemporary child message-bearer alongside the figure whose professed purpose was to provide a direct intercessor between humanity and divinity (real and beyond real) is unmistakable. That Joseph and Martha are so close in both name and class to Christ's parents in the Gospel stories, ${ }^{134}$ coupled with the fact that Diamond is forever being identified as an angel or as 'God's baby,' provide additional hints about the way in which MacDonald intends Diamond to be read. However, with a narrative playfulness of which Kingsley would have been proud, MacDonald never actually makes explicit beyond doubt the link between Jesus and Diamond. It is a connection which is never wholly corroborated and the strength of which is left entirely to the discretion of the book's reader. Whatever one's stance on Diamond's relationship with Christ, though, the point which is indubitable following Diamond's excursion to the back of North Wind is that

\footnotetext{
${ }^{134}$ In fact, it appears that it is so tempting to read Joseph and Martha literally as Joseph and Mary that Wolff actually makes this very mistake in The Golden Key. (RW, p. 156) To do this, though, negates MacDonald's narratory achievement of affiliating Diamond's family with that of Christ without ever actually making this comparison utterly transparent. In addition, if biblical sources for MacDonald's characters were being sought, it seems that Martha, sister of Lazarus, is a far more apt model for Diamond's mother than is Mary, Mother-of-Christ, since Christ once chided Martha for being too worried and busy with things of the world to understand or have time for spiritual teaching. (Luke 10. 38-42) Such a reproach is also directly applicable to the sort of spiritual impoverishment which deprives MacDonald's Martha of reciprocity with her child.
} 
he subsequently understands himself and his purpose in a way that those around him including us as readers - cannot. We cannot establish beyond the bounds of doubt exactly what he is, as he blends elements of working-class Victorian boy, Romanticized über-child, Son-of-God, and indefinable other. He has become the reverse of his position at the beginning of the book. He is now on the outside looking in. He is extra to humanity and is thereby necessarily isolated from it:

“The cabbies call him 'God's baby,' [Nanny] whispered. "He's not right in the head, you know. A tile loose."

Still Diamond, though he heard every word, and understood it too, kept on smiling. What could it matter what people called him, so long as he did nothing he ought not to do? And, besides, "God's baby" was surely the best of names!

(NW, p. 149, my emphasis)

Like the Christ whom he allusively emulates, Diamond brings a redemptive message that is only ever half heard and even then only half understood. Nanny uses 'God's baby' as a term of derogation, to demonstrate that Diamond is in some way mentally deficient, whereas Diamond hears it as a term of the highest approbation towards the implications of which he should further aspire. Like Christ, Diamond dies and is born again (as he travels to and from the back of North Wind), and is notable for the fact that he does not die at his book's end but instead, to paraphrase the narrator, returns once more to North Wind's back (in his equivalent of Jesus' Ascension). (NW, p. 292) Diamond's monstrosity is confirmed, both by his circumstances in Victorian society and by his associations out of it. Like Tom and Alice before him, Diamond castigates his community, but he does so using a (potentially unsettling, if not frightening) breadth of spiritual wisdom and power towards which they can only aspire. 
CHAPTER TEN

J.M. BARRIE: 'I CAN'T GET MY SHADOW TO STICK ON' 
As a component part in a discussion of the notion and presence of monstrosity in English children's literature, the character of J.M. Barrie's Peter Pan is integral. Pan's monstrosity is manifold, and arises from a combination of some of the more central monstrous phenomena that have already been identified in this thesis' previous chapters. These can be reduced, in this instance, to three primary features: Pan's textual association with his fellow characters; Pan's perceived association with Barrie; and Barrie's construction by literary critics. What is surprising about these, however, is that Pan's textual association with his fellow characters the only relationship from amongst the three for which there is the coherent and enclosing primary evidence of the various Pan texts - is often neglected in comparison to the latter two. In fact, through what appears to be an obsessive compulsion on the part of critics to read Barrie rather than his writing, the character of Pan is ironically rendered even more shut out and voiceless than it already manifestly is. Roger Lancelyn Green has written that 'a study of Peter Pan begins inevitably with a study of James Matthew Barrie, ${ }^{, 135}$ and perhaps it does, but it should not inevitably end there as well. To confirm this point, this chapter will discuss the problems of author-centric readings of Pan, before analysing the ways in which Barrie's construction of Pan's character in relation to those around him reinforces Pan's status as an undoubted textual monster. This will involve the examination of Pan's critical shadow (which comprises the things that haunt him - that are inevitably though distantly joined to him - and from which he tries in part to escape) before concluding, if possible, by sewing it back on. In the elements of Pan's shadow, in short, is to be found his difference. In Pan's shadow is to be found his monstrosity.

${ }^{135}$ Roger Lancelyn Green, Fifty Years of Peter Pan (London: Peter Davies, 1954), hereafter $R G$, p. 2. 
Jacqueline Rose, in the introduction to The Case of Peter Pan, defines what she, in her book's subtitle, refers to as The Impossibility of Children's Fiction:

Children's fiction is impossible, not in the sense that it cannot be written (that would be nonsense), but in that it hangs on an impossibility, one which it rarely ventures to speak. This is the impossible relation between adult and child. Children's fiction is clearly about that relation, but it has the remarkable characteristic of being about something which it hardly ever talks of. ${ }^{136}$

Rose's contention is that the result (perhaps even the purpose) of this notional rupture between addresser and addressee in the case of children's fiction is that it enables the writing adult to grasp independent and distant reading children through the images of youngsters which are built up inside children's books. Children's books are, after all, more often than not about children: 'children's fiction sets up the child as an outsider to its own process, and then aims, unashamedly, to take the child in.' $(C P$, p. 2) This enmeshing of child figures within a literary context is interpretable as an attempt on the part of the writing adult to seduce, appropriate, and control the reading child audience. A more extreme understanding of it might even represent it as the sort of technique that could be used by covert manipulators of children or paedophiles as a means through which to play out their socially unacceptable predilections.

These sorts of approaches, whilst undoubtedly valid on occasion, tend to predispose readings of children's authors towards the twin processes of demonization and witch-hunting. They are not, therefore, universally helpful. Thankfully, Rose goes on to advocate an alternative to them which is both plausible and logical. She suggests that textual fetishization of children does not necessarily constitute the personal fulfilment of either a sexual or a manipulative authorial impulse, especially given that many of the authors who are accused of

\footnotetext{
${ }^{136}$ Jacqueline Rose, The Case of Peter Pan, or the Impossibility of Children's Fiction (Philadelphia: University of Pennsylvania Press, 1993), hereafter $C P$, p. 1.
} 
such practices are characterized biographically as having been nervous of sexual relations (Dodgson is a case in point). Instead, the promotion of or focus upon innocent asexual child figures in such instances might actually comprise an authorial effort, whether conscious or not, to investigate rather than pollute the boundaries of childhood sexuality. In other words, fetishized children, explicitly removed from the real adult world in which the immediacy of sexuality must forever remain an incessant threat to them, can function for a willing author as tools with which to examine the features that define the rupture between the textual and real worlds of children and adults.

This unspoken relationship - the distance between receiving children and writing adults in the case of children's literature (fact as well as fiction), and the alienation of children which is an inherent part of it - is, of course, a large part of what this thesis is about (albeit in somewhat different terms). Children, Rose tells us, are different from adults, yet neither party can quite tell why. As a result, children become monstrous to adults; not necessarily things of evil, but things which are nevertheless of demonstrable and demonstrative divergence. The investigation, whether conscious or not, of this irreducible hinterland between children and adults is certainly one credible explanation of the function of children's literature, and, for Rose's elucidation of this possibility, this work is greatly indebted to her. Rose also shows her balance through her awareness of and caution about modern criticism's inclination to mis-sexualize innocent child figures written about by child-loving adults. Such readings result invariably in an intertext between loaded biography and pliable literature, and seem more concerned to concretize an author's perceived sexual deviance than they are to interpret the author's literature. From amongst the writers of English children's literature, we have already identified Dodgson as one of the men who are most regularly tarred by the implications of this witch-hunting brush. The other main one, of course, is Barrie. In neither case have charges of biographical or textual paedophilia ever been proven conclusively, and 
yet these are accusations that remain tricky to dispel. Barrie's reputation has suffered particularly, perhaps because his supposed transgressions involve not only the possibility of paedophilia, but homosexual paedophilia at that. Pan, it is argued, is a character around whom Barrie built a world in which he could enshrine and ensnare the adorable youthfulness of his eventually adopted children, the five sons of Arthur and Sylvia Llewelyn Davies, for the purpose of maintaining them forever as his textual playthings. Such ostensible literary sordidity, particularly when perpetrated by one who had such an indubitably peculiar childhood $^{137}$ and who never took the trouble to disguise his fondness for certain children, leaves Barrie a clear target for either Freudian analysis or tabloid lampooning. His status, whether rightly or wrongly, has undoubtedly been damaged by a combination of both. However, against such renderings there jars the essential evidence of Nicholas Llewelyn Davies (the youngest of the five brothers), as recorded in a footnote by Andrew Birkin:

I had written to Nico asking him whether he felt that Barrie had been platonically in love with George and Michael. In a later letter he wrote, "I'm 200\% certain there was never a desire to kiss (other than the cheek!), though things obviously went through his mind - often producing magic - which never go through the more ordinary minds of such as myself... All I can say for certain is that I... never heard one word or saw one glimmer of anything approaching homosexuality or paedophilia: had he had either of these leanings in however slight a symptom I would have been aware. He was an innocent - which is why he could write Peter Pan."

In summary, on whichever side of the proverbial fence one sits with respect to the biographical question mark over Barrie's sexuality and its arguable manifestation in relation to his child friends, it seems that one can find plausible evidence to support one's position.

\footnotetext{
${ }^{137}$ David Barrie, the family's favourite son, died on the eve of his fourteenth birthday (when James was only six). 'Jamie felt that if his brother David returned, his mother would be happy again. So he pretended to be David. He put on his brother's clothes and imitated his special whistle. At first his mother must have wept when he did this, but gradually she began to see the humor in it and occasionally even laughed. In a notebook, Jamie kept track of the number of times she laughed in a day and reported the number to the doctor when he came to check on her. He became a convincing actor. At home he tried anxiously to please and impress her. He did everything he could to divert her from thinking about her dead son.' (Susan Biver Aller, J.M. Barrie: The Magic Behind Peter Pan (Minneapolis: Lerner Publications Company, 1994), p. 19)

${ }^{138}$ Andrew Birkin, J.M. Barrie \& the Lost Boys (London: Constable, 1979), hereafter AB, p. 130.
} 
In the context of the research done for this thesis, however, it would appear that, if Barrie did have any sexual leanings towards any of his child friends, these remained both unexpressed and unconsummated. And, in fact, whether or not they existed, as R.D.S. Jack succinctly puts it:

Such concerns still seem at best peripheral to the problem of literary evaluation. The fact remains that many writers on Barrie use the idea of perversion to call into question the validity of his art or to explain its limitations. ${ }^{139}$

In other words, in spite of the dubious intrigue of approaches to Barrie that focus upon relating his debatable sexuality (and indeed any other aspects of his biography) to the contents of his books, such methodologies are objectively unsatisfactory. What needs to be produced henceforth is an investigation into the history and status of Pan, rather than those of his creator.

As a brief caveat, though, and having observed that a monolithic reading of abusive authorial sexuality into Barrie's writing is one that causes misleading complications and which is arguably even irrelevant, it would be naïve to deny in the same breath the presence of sexual and procreative discourse in the Pan texts. Clearly, a character who has an aborted parental background, and who seeks (whether or not he knows it) the maternal whilst denying the paternal, cannot be understood fully away from the mechanisms of human conception. Accordingly, as this discussion addresses the monstrous implications of Pan's boy-eternal alienating stasis, it will examine his complex textual conception and context, and - in the light of this - compare his character's functionality to those of the other characters with whom he associates in Barrie's work. In these two assessments will be found the reasons why Pan should be thought of as the archetypal child solitary, and why his tragic

\footnotetext{
${ }^{139}$ R.D.S. Jack, The Road to the Never Land: A Reassessment of J M Barrie's Dramatic Art (Aberdeen:
} Aberdeen University Press, 1991), p. 9. 
monstrosity can be used - as Rose has done - to speak volumes to us about the impossibility of childhood.

(ii) 'You will be a Betwixt-and-Between:' The Monstrosity of Context

If monstrosity is a feature which is made manifest in discourse by the presence of a somehow unacceptable layer of difference, then it may be extrapolated that occasions will arise when monstrosity will be defined or enlivened simply as a result of the context in which it is born. Frankenstein's monster is one of the foremost literary examples of this syndrome. The creature is born a childlike innocent and is unaware of its monstrous context, but it ends up re-immersing itself in death as a combined result of its creator's rejection of it and its own inherently deathly construction. It becomes a self-fulfilling prophecy. It becomes the monster it was always destined to be.

By comparison, Barrie's conception of Pan is less obviously problematic than the diabolic obstetrics of Frankenstein's creature. From Barrie, Pan just materializes, as a character who lived on the Birds' Island in the middle of the Serpentine, in the Kensington Garden stories with which Barrie used to regale the Llewelyn Davies children:

It was, [Barrie] said, on Birds' Island that all the birds were born who became, in due time, baby boys and girls. The Llewelyn Davies boys heard a great deal about the Birds' Island, and presently another name slipped in, Peter Pan. No one knew where he came from, least of all his creator. Barrie was in the habit of naming his imagined characters after children he knew, and Peter Davies was there, handy. The Pan part tacked itself on quite naturally. Peter Pan. The boys soon got to know him as if he actually existed. ${ }^{140}$

Janet Dunbar's peculiar observation here, that Barrie could not rationalize the origins of Pan, is substantiated by Barrie's own hand, in his dedication to the first published edition of Peter Pan, or the Boy Who Would Not Grow Up:

${ }^{140}$ Janet Dunbar, J.M. Barrie: The Man Behind the Image (London: Collins, 1970), pp. 125-6. 
As for myself, I suppose I always knew that I made Peter by rubbing the five of you violently together, as savages with two sticks produce a flame. That is all he is, the spark I got from you... [It is] my uncomfortable admission that I have no recollection of writing the play of Peter Pan, now being published for the first time so long after he made his bow upon the stage. You had played it until you tired of it, and tossed it in the air and gored it and left it derelict in the mud and went on your way singing other songs; and then I stole back and sewed some of the gory fragments together with a pennib. That is what must have happened, but I cannot remember doing it. ${ }^{141}$

Amidst these authorial admissions of creative amnesia, the Frankenstein analogy no longer seems to be quite so far off the mark. Sinisterly, Barrie talks of his play as a dead thing which has been stitched together from shattered parts. Only after the children who were its inspiration had long since tired of it and left it abandoned, could its grave-robbing author return, gather up its scattered limbs, and return them to unity for re-enlivenment as a published play. ${ }^{142}$ Equally disquieting, in the context of a discussion of monstrous or unnatural creation, is the fact that Barrie uses his dedication to establish his play as the offspring of the Llewelyn Davies boys; the child of children. He figures himself, at the most, as an intermediary in the process of its creation. As an indicator of the distance between the worlds of adults and children, we know that it is not acceptable in either social or biological terms to countenance the idea of children bearing children, and yet that is precisely what we are told is happening - on a figurative level - in this instance. Child and adult roles metaphorically collapse, as Barrie's conceptualization of five little boys leads in his mind to the genesis of a sixth. Pan is the child of children. He is the monster of monsters.

Philosophically, this may be so, but, for the purposes of biological plausibility, Pan also has in his textual history a legitimate (though oft-forgotten) mother. She, along with Pan,

\footnotetext{
${ }^{141}$ J.M. Barrie, Peter Pan, or the Boy Who Would Not Grow Up, in J.M. Barrie, Peter Pan and Other Plays, ed. by Peter Hollindale (Oxford: Oxford University Press, 1995), hereafter POP, 73-154, hereafter $P P$ (pp. 75-6).

${ }^{142}$ Indeed, by this point in Pan's history, two of the five Llewelyn Davies brothers were already dead: George, the eldest, was killed in action in France in 1915; Michael, the fourth and Barrie's favourite, drowned in what was taken to be a swimming accident (although there is an unproven suggestion that it might have been a suicide pact) in Oxford in 1921.
} 
first appears in publication in a book for adults entitled The Little White Bird (1902), which Peter Hollindale summarizes as 'a collection of diverse episodes, widely differing in tone and ranging from whimsy and fantasy to social comedy, with comedy employed at times to veil and permit the utterance of darker, more aggressive meanings. ${ }^{, 143}$ Within this book, there is a section, written as a semi-conspiratorial one-way implied dialogue with a child called David, which tells of Pan and his origins. This material was collated and republished separately, as Peter Pan in Kensington Gardens, in 1906. Peter Pan in Kensington Gardens confirms that Peter has been around for quite some time, and that, in fact, he knew both the parents and the grandparents of the book's implied child reader:

Of course, [this] shows that Peter is ever so old, but he is really always the same age, so that does not matter in the least. His age is one week, and though he was born so long ago he has never had a birthday, nor is there the slightest chance of his ever having one. The reason is that he escaped from being a human when he was seven days old; he escaped by the window and flew back to the Kensington Gardens. ${ }^{144}$

Remembering that, inside Barrie's fantasy world, children begin their lives as birds before eventually becoming human, it would appear that the Pan who flew out of his nursery window (and away from his mother) at the age of one week had not yet been around for sufficient time to make successfully the transition from the avian. Having navigated his way to the island in the middle of Kensington Garden's Serpentine, however, Pan is brought down to earth - literally - by the island's spiritual leader, Solomon Caw. Solomon informs Pan of his humanity, and, in doing so, deprives him of his ability to fly (because humans, obviously, cannot fly):

"You must live here on the island always[," said Solomon Caw].

"And never even go to the Kensington Gardens?" Peter asked tragically.

143 Peter Hollindale, 'Introduction,' in J.M. Barrie, Peter Pan in Kensington Gardens \& Peter and Wendy, ed. by Peter Hollindale (Oxford: Oxford University Press, 1991), hereafter P\&P, vii-xxviii (p. xix).

144 J.M. Barrie, Peter Pan in Kensington Gardens, in $P \& P, 1-65$, hereafter $K G$ (p. 12). 
"How could you get across?" said Solomon. He promised very kindly, however, to teach Peter as many of the bird ways as could be learned by one of such an awkward shape.

"Then I shan't be exactly a human?" Peter asked.

"No."

"Nor exactly a bird?"

"No."

"What shall I be?"

"You will be a Betwixt-and-Between," Solomon said, and certainly he was a wise old fellow, for that is exactly how it turned out. $(K G$, p. 17)

That is exactly how it turned out indeed, for, although Pan eventually regains the power of flight through the magic of the Fairy Queen, his lack of definition has now been, for want of a better word, defined. True, Pan uses his restored gift to return to his nursery and look in silently upon his mother (who, in the way of good mothers everywhere, has left the window open for him to return at a time of his choosing), yet he cannot make the choice to enter permanently. He cannot settle upon being a human child, for, as Solomon has told him, he no longer has the capacity to be exactly a human. By the time Pan does eventually decide that humanity is his rightful road, his point of entry is denied: 'the window was closed, and there were iron bars on it, and peering inside [Pan] saw his mother sleeping peacefully with her arm round another little boy.' $(K G$, p. 40$)$ Pan is shut out from his mother, his childhood, and any semblance of normality that he might have been able to salvage after his early fantastical adventures. He is alone. He is a monster.

Monsters, however, have a habit of returning (Pan kept coming back to his nursery window before it was eventually barred to him), and the character of Pan was not to be wound up so easily. By March $1^{\text {st }}, 1904$, a play about him had been completed in Barrie's notebook under the title of Peter \& Wendy. (AB, p. 103) After a failed application to one London producer, Barrie took the play, under the revised title The Great White Father, to his long-term friend Charles Frohman. Frohman, an influential Broadway producer, fell in love with the text, and, with the one caveat that its title should be changed simply to Peter Pan, 
offered to bankroll the play's production completely. On the $27^{\text {th }}$ of December of that same year, Peter Pan, or the Boy Who Wouldn't Grow Up opened in the Duke of York's Theatre in London, to a rapturous response (which has been recorded effectively in the majority of the available biographies of Barrie). This play's text, with diverse interpolations and alterations, was eventually published in 1928 under the full title Peter Pan, or the Boy Who Would Not Grow Up. Peter and Wendy, the play's novelization, was published previously in $1911 .^{145}$ Finally, the closing scene of Peter and Wendy, in which Pan returns to the Darlings' nursery to discover that Wendy has become a grown up and has acquired a daughter of her own, was published for stage as When Wendy Grew Up: An Afterthought in 1957. This was only once played during Barrie's lifetime, at the end of the 1908 season. $^{146}$

This textual history of Pan, from his inspiration in the Llewelyn Davies brothers through to the publishing of his final bow over half a century later, tells us much about his development through the precision of Barrie's obsessive revisions. We already know that Pan's essential otherness was defined in publication prior to the release of the play which made him so famous, but we must also consider the additions to this otherness which are provided even at the level of the manifold titles under which he is to be found. Frohman was absolutely right to reject the title The Great White Father (which, for all the world, sounds like a grown-up successor to The Little White Bird), for, in spite of the fact that this is the name by which Pan is known to the Piccaninny Braves after he rescues Tiger Lily from the pirates, it is nevertheless a name which is emblematic of that which Pan is not. Pan, as shall be seen later, is not a father, though he plays sporadically at being one. Equally, the full title of Peter Pan, or the Boy Who Would Not Grow Up (which rightly implies that Pan's

\footnotetext{
${ }^{145}$ For the sake of simplicity, given the considerable textual overlap between these two central works, the majority of quotations here will be from the published text of Peter Pan. The only exceptions to this will be on those occasions when either a specific detail that is present only in the novel needs to be addressed or when the texts of the play and the novel deviate substantially. These occasions will be signalled clearly.

${ }^{146}$ Peter Hollindale, 'Introduction,' in POP, vii-xxv (p. vii).
} 
existence as a boy-eternal is one of his own choosing) has palpably different connotations to Peter and Wendy, the notebook title under which Pan's story was first written and under which its novel form was eventually published. The play's fuller title tells the truth of Pan's status; it focuses, as perhaps its namesake would prefer, upon Pan himself and the unique wonderfulness of his never-ending youth. By comparison, the novel's title tells us of two characters, and implies a conjunction between them; a conjunction which one of them (Pan) is, at least on occasion, willing to deny.

So, given the existence of these various alternates, where should titular emphasis be placed? Should it be given to Pan, the specific character, or to one or both of Peter and Wendy? Come to that, can Peter, actually, be separated from Wendy? When Wendy Grew Up: An Afterthought certainly seems to suggest that he can, since Wendy's name has by this point muscled Pan's out of the title picture. Yet, like the monster that he is, Pan comes back in When Wendy Grew Up. He returns to the adult Wendy and, when he finds her changed, transfers his affections onto her daughter Jane. Jane greets Pan with the same words and actions used by her mother in Peter Pan's first act: 'JANE: "Boy, why are you crying?" (Peter rises - they bow as in Act I). ${ }^{, 14}$ All this reveals that the complete name of this short additional conclusion is something of a suggestive misnomer, since this sequence is clearly anything but an afterthought. Instead, When Wendy Grew Up essentially delineates the boundaries of Pan's recurrent condition and shows the contradiction of his fixed transience across the inevitability of passing years. Just as Pan was present in our grandparents' generation in exactly the same way that he is present now, so, When Wendy Grew Up implies, he will be present when we too are grandparents. He will still be the same little boy, and he will remain equally unincorporated and unfixed, and in this paradox is his monstrosity.

${ }^{147}$ J.M. Barrie, When Wendy Grew Up: An Afterthought, in POP, 155-63 (p. 162). 
The variety and shifting emphases that we see in the titles of Barrie's texts are reflected too in the movable name of the island to which Pan flies the Darling children. As Humphrey Carpenter records, the place was called "Never Never Never Land" in early MSS of the play; "Never Never Land" in the final production script, and so usually in performance; "Never-land" in Peter and Wendy; "Never Land" in the published text of the play.' (HC, p. 230) Each of these permutations has it own subtly different resonance. Never Never Never Land possesses the undertone of an exclamatory childish tantrum ('Never! Never! Never!'), and its repetitiveness puts especial emphasis on the negative through the noun Land's appearance as an apparent afterthought. This, surely, must be a place of despair, where the operation of life is governed by the reductive mantra of never never never. Never Never Land, on the other hand, as Green observes, hints simultaneously at a place that is far away and uninhabitable, but which could nevertheless be a site of (unrealizable) utopian imaginings and aspirations. ${ }^{148}$ There is as well, if we read never never in its colloquial form as a term synonymous with the hire purchase system, the allusion that Never Never Land is a place in which one might live on some sort of borrowed time or credit. In that sense, Hook, in relation to the rhythmic pulse of the crocodile that so hungrily and persistently follows him, lives quite literally on the tick. Even Never-land and Never Land suggest different meanings. Never-land, through its hyphenated totalising conjunction, implies a world of pure fantasy (never-land as a site of fantastical nothingness, a land that is never). Never Land, through its segregation and separate proper noun capitalizations, asks that its components be approached without the presumption of complete interdependence (perhaps leaning towards an understanding of a world in which one can never land, never become grounded, in the way that pirates attempt literally to prevent the landing of Pan with the

\footnotetext{
148 'There was an actual place in Australia called the Never, Never Land which in 1902 gave its name to one of Wilson Barrett's last plays: Barrie must have heard of it - but no one would deny that he had chosen the right name for Peter Pan's island, the island which we all seek in childhood but never, never find in anything but dreams and imaginings.' $(R G, \mathrm{p} .34)$
} 
Darlings in Peter and Wendy's early stages). Unfortunately, there seems to be no primary evidence from Barrie himself to corroborate his own feelings with respect to these divergent possibilities (although whether or not it is realistic to expect an author to record selfconscious commentaries on such changes is a moot point). However, the simple fact that they exist suggests, particularly alongside their host texts' fluctuating titles, that the attempt to find a location for Pan - both geographically within his stories, and extra-textually in the outside world - was an essential feature of his character for Barrie.

Of course, though, Pan's must be a location lost, since, from the moment of his inception, he is shut out from location. Pan is, inescapably, a Betwixt-and-Between, and this leads us to what is perhaps the most interesting of Barrie's textual interpolations into the fabric of his play. In Pan's initial conversation with Wendy in the Darling's nursery, he tells Wendy that he has no mother. She responds immediately by trying to give him a sympathetic hug:

(She leaps out of bed to put her arms round him, but he draws back; he does not know why, but he knows he must draw back)

PETER: You mustn't touch me.

WENDY: Why?

PETER: No one must ever touch me.

WENDY: Why?

PETER: I don't know.

(He is never touched by any one in the play)

This exchange between Peter and Wendy was introduced into Peter Pan's 1928 text, supposedly to complement the on-stage skills of Jean Forbes-Robertson, who presented Peter with what has come to be regarded as a unique ethereality between the 1927 and 1935 London seasons. However, there is no analogue to this conversation in Peter and Wendy, in which Wendy and Peter notably manage to exchange 'thimbles' (kisses) before Tinker Bell pulls Wendy off by her hair (in Peter Pan, Tinker Bell's aggression prevents contact between the two). Critical response to this addition is mixed. Hollindale, one of OUP's modern 
editors of Barrie, regards it fundamentally as a good thing: 'a Peter resistant to actual physical contact, always insulated from the mortal, is wholly in keeping with the role and gives ample opportunities for visually effective and meaningful "close encounters" later in the play. ${ }^{149}$ J.A. Hammerton, on the other hand, writing at the time of the change's stage introduction, is more sceptical:

It weakens the conception of Peter as having anything of the boy about him. We cannot have the same sympathy for a changeless and deathless thing that cannot be touched by mortal hands that we had for a Peter who used to be half mortal and half immortal. The immense sense of loneliness which "the tragic boy" left upon us came from the mortal part of him. Cut out his humanness entirely and we lose touch with him. ${ }^{150}$

Both viewpoints are persuasive, but their true fascination lies in the fact that they home in together upon the implications which Barrie's interpolation has for Peter Pan's perceived mortality. Both Hollindale and Hammerton argue that Pan's untouchability makes him less mortal and less easy to fix: the only bone of contention between them is whether or not this effect is desirable.

Intriguingly, Barrie's 1928 addition also serves to align Pan distantly with Jesus, at least according to John the Evangelist's account of the conversation of the resurrected Christ with Mary Magdalene. Christ, on this occasion, provides the western religious example of untouchability par excellence: 'touch me not; for I am not yet ascended to my Father.' (John 20.17) Christ claims untouchability as a result of his unprecedented post-resurrection condition. He has become, as a result of what he has been through, a Betwixt-and-Between: one who is between the dwelling place of humanity and the dwelling place of God. After this conversation, John's Gospel records only one example of Jesus being touched (by Thomas, the disciple who doubts the mortal veracity of the risen Christ). The question and function of attainability in Barrie's young protagonist, therefore, draws him into imaginative proximity

\footnotetext{
${ }^{149}$ Peter Hollindale, in $P O P$, p. 313.

150 J.A. Hammerton, Barrie: The Story of a Genius (London: Sampson Low, Marston \& co., 1929), p. 256.
} 
with the divine figure of Christianity's demonstrative redeemer, and makes Pan, like Christ, a very message bearer. If there were any doubt over the power that is attributable to the demonstrative faculty of Pan's condition, then this association must go some way towards dispelling it.

Returning to the debate between Hollindale and Hammerton, however, and given what has been seen here of the fluidity of the titles and material with which Pan's character is surrounded in Barrie's writing, it would appear that Hollindale is right at least to observe that Barrie's 1928 scene is in keeping with the role of Pan. As Ann Yeoman puts it, 'his elusive character makes Peter Pan impossible to fix: ${ }^{, 151}$ even in the mind and pen of his creator, Pan's is a character that it is not viable to pin down, and he must therefore be untouchable. Thus, Barrie's 1928 conversation between Pan and Wendy corroborates that which is fundamental to the artistry of the Pan works, which is that the little boy's textual status is inherently that of the one who looks in through windows. He is close but he cannot be drawn closer. He is outside but he cannot be welcomed in. He is a boy but he cannot be made human.

\section{(iii) Problematic Paternity}

Textually, then, one might say that Pan is built into a position of monstrosity that is similar to that with which Kingsley surrounds Tom in The Water-Babies. The respective isolations of these two children are not merely a result of any character traits that they share, but are actively promoted by the mechanisms of the textual constructs within which they are framed. Like Tom as well, Pan is a demonstrable monster with respect to his relationships with other characters (as has already been seen in the example of Barrie's 1928 (no) touching addition to the 1928 published text of his play). It is towards this that we shall now turn because it is

\footnotetext{
${ }^{151}$ Ann Yeoman, Now or Neverland: Peter Pan and the Myth of Eternal Youth (Toronto: Inner City Books, 1998), p. 81.
} 
in instances of this syndrome that we may more fully explore the function of Pan's character critique of childhood. A reasonable amount of work already exists in this field, examining Pan through filters such as Freudian analysis, ${ }^{152}$ gender discourse, ${ }^{153}$ and book illustration. ${ }^{154}$ As far as possible, this material will not be repeated here (although it should be noted that Michael Egan's thinking, ideologically if not terminologically, is very much in keeping with the thrust of this thesis). Instead, this chapter will now focus upon a peculiar feature of the figures with whom Pan interacts, the implications of which, when developed, are absolutely of the essence to a full reception of his character.

In all the texts in which Pan has dealings with the Darlings, the participants can be subdivided into one of three categories: (i) children (Pan, Wendy, Hook, Mr Darling, the pirates, and the Lost Boys); (ii) mothers (Wendy, Mrs Darling, and Nana); and (iii) female lovers (Wendy, Tinker Bell, and Tiger Lily). What is interesting about this list is that fathers and male lovers - social and physical positions which are necessarily bound up both with each other and with mothers, female lovers, and children - are noteworthy in it by their absence. Even though fathers and male lovers are present emblematically in the Pan texts, the stories unwaveringly refute them. Wendy, by comparison, is ubiquitous, and takes on every role that the play has to offer. It is the dialogue between these two details which we will now examine.

\footnotetext{
${ }^{152}$ Michael Egan, 'The Neverland of Id: Barrie, Peter Pan, and Freud,' Children's Literature, 10 (1982), 37-55, hereafter $M E$. Egan argues that Barrie's story unconsciously creates a symbolic metaphor (which Egan refers to as the Neverland) of the child's id, and that this becomes populated with characters whose interactions have strong Freudian resonances (as in, for example, the arguably Oedipal relationship between Pan and Hook).

${ }^{153}$ Susan S. Kissel, "'But When at Last She Really Came, I Shot Her:" Peter Pan and the Drama of Gender,' Children's Literature in Education, 19.1 (1988), 32-41. Kissel's study suggests that Barrie's Pan texts have much to say about gender roles in Western culture, and examines the way in which gender difference is reinforced throughout Barrie's work.

${ }^{154}$ Chris Routh, "'Man for the Sword and for the Needle She:" Illustrations of Wendy's Role in J.M. Barrie's Peter and Wendy,' Children's Literature in Education, 32.1 (2001), 57-75, hereafter CR. This article, focussing on Peter and Wendy, considers the way in which three illustrators have responded to Wendy's role as a mother in the novel (focussing on her especially as a storyteller and as a seamstress). Routh reveals that profoundly different visual interpretations of pivotal scenes are more than possible, whilst nevertheless remaining true to Barrie's text.
} 
Let us consider first those who could be called fathers in Peter Pan. Mr Darling is the clearest claimant to this title, as the identified male parent of Wendy, John, and Michael, and the supposed patriarch of the Darling establishment. Yet, in truth, he never even comes close to fulfilling his paternal role. In the play's first act, for example, when $\mathrm{Mr}$ Darling is encouraging Michael to take his apparently foul-tasting bed-time medicine, Wendy's maternal suggestion, that Mr Darling should take his (even more horrid) medicine at the same time in order to encourage Michael, reduces Mr Darling to a linguistic level identical with that of his youngest son:

MR DARLING: That is not the point; the point is that there is more in my glass than in Michael's spoon. It isn't fair, I swear though it were with my last breath, it is not fair... MICHAEL: Father's a cowardy custard.

MR DARLING: So are you a cowardy custard.

$$
\text { (PP, pp. 94-5) }
$$

Subsequently, it having been agreed that both victims will imbibe their respective tonics at the same time, Mr Darling resorts to cheating and misses taking his. Michael, John, and Wendy are struck by the unfairness of this, and their contempt for their childish father is compounded when he pours his medicine into the bowl of the nurse dog, Nana. That Nana then - rightly - receives the sympathy of the others for the crime which has been perpetrated against her, is more than Mr Darling can bear, and he desperately tries to reassert his (nonexistent) paternal authority by chaining up Nana outside:

MR DARLING: I refuse to allow that dog to lord it in my nursery for one hour longer... In vain, in vain, the proper place for you is the yard, and there you go to be tied this instant... Am I master in this house or is she?

(PP, p. 96)

The choice of language here could hardly be more specific: Mr Darling refuses to allow Nana to lord it any longer over the Darling establishment, and he wishes to demonstrate his mastery by making an example out of her. Both terms are attempts by Mr Darling to reclaim 
his masculine authority (he wants to be lord, he wants to be master), but both actually serve to do nothing more than reinforce the growing sense that he is a childish and insecure despot. That he later goes on to retreat into Nana's kennel when faced with the enormity of his children's disappearance finally confirms his position, because he takes up, as a result of clear obsession with ordering things about him, the proper place that has been brought on him by his decision to leave Nana outside on that fateful night. This is not the response of a pro-active father, who would go all-out to find his missing little ones. This is the response of a defensive child, admitting its helplessness and building around itself a cocoon within which to nurse its hurt.

There is, therefore, a disjuncture in Mr Darling. Practically and, by implication, biologically, he is a father: the three Darling offspring certainly regard him as their dad, and there is no suggestion that the children are not legitimately his. However, characteristically, Mr Darling is a child: he shows neither paternal leadership nor responsibility, and is thus reduced to a childish status. The only other character in the play who consistently claims the position of paternity is the very reverse of this model, and is, of course, Pan himself. Pan, unlike Mr Darling, is nervous of (the implications of) the title of father, but he nevertheless shows a greater number of fatherly characteristics. As soon as Wendy's house is built at the end of Act 2, Pan marches up and down outside it in order to protect it and its contents from the carousing pirates. $(P P$, p. 116-7) It is mentioned later that Pan is known amongst the Piccaninnies as the Great White Father for his bravery in rescuing Tiger Lily. (PP, pp. 128-9) In Act 4, when Pan returns home as the breadwinner to the under ground home of the Lost Boys (bringing with him, in a bag, what he claims to be the heads of two tigers and a pirate), Wendy announces him as the boys' father, and, in spite of the incredulity with which John receives this comment, they by-and-large treat him as such. Yet, even in the face of all these 
paternalistic character traits, Pan is clearly unnerved by the role which is being ascribed to him:

PETER: (scared) It is only pretend, isn't it, that I am their father?

WENDY: (drooping) Oh yes.

(His sigh of relief is without consideration for her feelings)

But they are ours, Peter, yours and mine.

PETER: (determined to get at facts, the only things that puzzle him) But not really?

WENDY: Not if you don't wish it

PETER: I don't

(PP, pp. 129-30)

So, whereas Mr Darling cannot cope with the actions of being a father, Pan cannot cope with the notion of being a father, because being a father would mean that he would have to become the one thing which he wishes so much to avoid, i.e., a grown up. Or, rather, in Pan's perception, being a father would mean that he would no longer have the option to be a little boy. Ironically, Mr Darling's little boyishness disputes Pan's supposition, particularly since we are reminded of Mr Darling almost immediately after the above exchange between Wendy and Pan when Pan uses one of Mr Darling's stock phrases to quieten down the Lost Boys: 'a little less noise there. ${ }^{155}$ (PP, p. 131) Pan's embodiment of fatherhood is hereby entirely undercut, not only by his reticence to engage mentally with the consequences of the role, but also by his assumption of the phraseology of a man who is known to be no adequate father. Between Pan and Mr Darling, there is perhaps one father and one rather scared child, but the two roles are confusingly blended within disparate identities.

This leaves us with only one other strong male character in Peter Pan to whom we can look to for potential paternal representation, Captain Jas Hook:

Cruellest jewel in that dark setting is Hook himself, cadaverous and blackavised, his hair dressed in long curls which look like black candles about to melt, his eyes blue as the forget-me-not and of a profound insensibility, except when he claws, at which time

\footnotetext{
${ }^{155}$ We know that this is a phrase used repeatedly by Mr Darling, not only because we have heard it from his own lips $(P P$, p. 91$)$, but also because we have heard John using it imitatively only a few lines before his father. (PP, p. 89)
} 
a red spot appears in them. He has an iron hook instead of a right hand, and it is with this that he claws. He is never more sinister than when he is most polite, and the elegance of his diction, the distinction of his demeanour, show him one of a different class from his crew, a solitary amongst uncultured companions. The courtliness impresses even his victims on the high seas, who note that he always says "Sorry" when prodding them along the plank.

(PP, p. 108)

On the basis of this evidence, Hook is not, perhaps, the most obvious of father-figures, but he undoubtedly possesses a verbal charm and the visual impact of a dark sexual attraction. His, one might say, is a primal fatherhood; a pre-paternal potential paternity. Certainly, his magnetic personality is one to which Wendy - the mother figure in Barrie's texts and their emblem of female sexual possibility - proves far from immune. In the scene from Peter and Wendy in which the pirates capture the Lost Boys, Wendy is notably accorded a very different treatment to the roughness which greets the others:

With ironical politeness Hook raised his hat to her, and, offering her his arm, escorted her to the spot where the others were being gagged. He did it with such an air, he was so frightfully distingué, that she was too fascinated to cry out. She was only a little girl. $^{156}$

In Hook, then, there is the latent and striking masculinity which is so patently lacking from Mr Darling and Pan, but, like the other two, Hook's ability to be a father-figure is neutered by his utter inadequacy in other departments. True, Hook has a following of childlike pirates (in the way that Pan has a following of childlike Lost Boys) but he is nevertheless forced to admit that 'no little children love me... [and] they force the baby to be Hook [in play].' ( $P P$, p. 139) Not only, therefore, is he not loved as a father, but he is also characteristically reduced by the fact that his role is always given to the littlest child whenever children play at

\footnotetext{
${ }^{156}$ J.M. Barrie, Peter and Wendy, in $P \& P, 67-226$, hereafter $P W$ (p. 178). Michael Egan points out that the use of the French distingue in this extract is the only occasion on which Barrie utilizes French in the story, outside its euphemistic employment in relation to Tinker Bell's boudoir and negligeés. (NI, p. 46) Given that Tinker Bell is the story's most sexually aggressive character, this pointed use of French in her absence suggests that Hook is being permitted here to borrow just a little bit of the fairy's linguistic seductiveness.
} 
Peter Pan. Even his occasionally unleashed sex appeal does him precious little good, for the faux allure with which he initially enthrals Wendy amounts to nothing. Like both Pan and Mr Darling before him, Hook is gripped in and isolated by the coils of reductive male childishness: he has no more ability to escape into the idealized familial masculine role of adult paternity than they do. Hook, according to Kathleen Kelley-Lainé, 'is the saddest of the sad children. ${ }^{157}$ She might just be right.

Whilst reviewing Hook, it is important to note that in spite of his function as the ostensible personification of diabolism in the Pan stories, Barrie does not at any time require complete condemnation of his character: 'the man is not wholly evil: he has a Thesaurus in his cabin, and is no mean performer on the flute.' (PP, p. 136) Yes, Hook is an apparently unhinged killer, and, yes, he wishes for the death of Pan, but we are not to believe fully that he is a bad person. In fact, Hook's life situation is really rather sad, and bears direct comparison with those of both Peter Pan and Mr Darling. Describing her father acting the part of Hook in the first London production of Peter Pan, Daphne du Maurier states that:

He was a tragic and rather ghastly creation who knew no peace, and whose soul was in torment; a dark shadow; a sinister dream; a bogey of fear who lives in the grey recesses of every small boy's mind. All boys had their Hooks, as Barrie knew; he was the phantom who came by night and stole his way into their murky dreams. ${ }^{158}$

Here, Gerald du Maurier's version of Hook is resolved not only as a solitary character but also as one who exists independent of the text of Barrie's stories. Barrie himself plays up this aspect of the pirate captain, by stating that 'it is said [that Hook is] the only man that the Sea-Cook ${ }^{159}$ feared.' (PW, p. 114) Similarly, Michael and John get upset when Pan first mentions Hook because 'they knew Hook's reputation,' ( $P W$, p. 108), and Hook is not in fact

\footnotetext{
${ }^{157}$ Kathleen Kelley-Lainé, Peter Pan: The Story of a Lost Childhood (Shaftesbury, Dorset: Element, 1997), hereafter $K L$, p. 70.

${ }^{158}$ Daphne du Maurier, in $R G$, p. 38.

159 The Sea-Cook is Long John Silver, from Robert Louis Stevenson's Treasure Island (which was itself, at one stage, titled The Sea-Cook).
} 
the pirate's real name but 'to reveal who he really was would even at this date set the country in a blaze.' ( $P W$, p. 188) Thus, Barrie deliberately loads Hook with an extra-textual quality, identical to that with which he fills up Pan (remembering that Peter Pan in Kensington Gardens' narrative states that the little boy knew the reader's implied grandparents). From this, both Pan and Hook - at the same time and using the same method - expand beyond the boundaries of the plays and novels which textually confine them. We are told that we know these characters. They are of us. They are real. They are embodiments of cultural fantasy and of those things that culture represses. They are monstrous, inasmuch as they seek to show those things which society elects to hide. All boys may well have their Hooks, as du Maurier says, but likewise they also have their Pans, and as Hook steals as a dark phantom into children's dreams, so Pan too waits until night fall to make his entrance into the security of their nursery bedrooms.

There appears, then, to be a strong case for believing that the characters of Pan and Hook are manifestly bound up in each other. Both are solitaries, both are simultaneously quasichildren and quasi-adults (fathers), both exist extra-textually, and both come to children at night-time or in dreams. Mr Darling too should be added to this mix, although - since he is given less textual space in which to develop than Pan and Hook, and since he has not their fantastical extra-textuality - his function in this character mishmash is proportionally smaller than theirs. The key to the interrelation between these three males, beyond the fact that we were examining them together initially as a group of ostensible fathers, can be found in their interactions with the omnipurpose Wendy, the only character in the play who functions simultaneously as a child, a mother, and a female lover. Hook, for example, requires Wendy to operate in two out of her three roles: he desires her subtly as a lover, and more explicitly as a mother. The first of these is delivered interactively only for the most tenuous of flickering moments. Hook's sexual power is played, greeted with fascination by Wendy, and then left 
alone. The sensation produced is one which alludes to what may conjectured to be a deeper adult male need in the captain's character, but which is nevertheless present textually for so little time that - cleverly - it can never be accused justly of any form of (paedophilic) impropriety. More obviously, by comparison, Hook is also the president of a group of men who require maternity, ${ }^{160}$ and he refers to Wendy as the mother of the Lost Boys and to the Lost Boys as Wendy's children. This is the context in which he and his comrades most readily engage with the image of Wendy, and it is for this reason that he attempts, in Peter Pan, to recover control over his eventually mutinous crew by observing that there "never was luck on a pirate ship wi' a woman aboard.' $(P P, \mathrm{p} .144)$ The presence of a woman, and of Wendy especially, in the midst of the masculine safe-haven of the pirate ship, reminds the crew of the maternity (and perhaps even the sexuality) that they are so patently without. It reminds them of their dysfunction. It reminds them of their loneliness, on the decks of the craft that emblematizes their community.

Alongside the pirates, Mr Darling's relationship with his daughter highlights a similar predicament, except that his desire for Wendy is as a mother (Mr Darling, with his overt need to be coddled, seems to want everyone as a mother) and as a child. When Mr Darling plays his medicine trick on Michael and Nana at the story's beginning, he cannot bear Wendy's subsequent reproach, because it not only distances him from her as his child but it also transfers her caring maternal focus - and, indeed, the caring maternal focus of his wife - from him to Nana. The attention of both Wendy and Mrs Darling are thus removed from him in one moment by the presence of Nana, and - in spite of the fact that it is his mistreatment of Nana which gives rise to the situation - Mr Darling therefore has to dispose of Nana by chaining her up outside. His later withdrawal into the safety of Nana's kennel, however, corroborates his desire for maternal protection, since the kennel provides - by its association

\footnotetext{
${ }^{160}$ A need which is voiced by Smee towards the story's end, when Wendy is threatened with death: 'see here, honey... I'll save you if you promise to be my mother.' ( $P W$, p. 193)
} 
with the motherly nurse-dog - the maternal shelter that Mr Darling gets from nowhere else. Thus, his self-imposed isolation acts dually as an indication of paternal contrition (substituting himself for Nana, in the knowledge that if she had been present in the nursery on that fateful night then the children would not have been permitted to disappear) and selffulfilment. As Hook needs both a mother and a lover, so Mr Darling needs both a mother and his children.

The fact that there has been a tradition, since the original Gerald du Maurier performance in 1904, that Hook and Mr Darling should be played by the same actor, $(R G$, p. 222) combines implicitly the interactive requirements of both these characters inside one dual figure. Hook and Mr Darling, we are told by this (if indeed any further corroboration was needed), are at least related to each other, if not one and the same person. Clearly, $\mathrm{Mr}$ Darling could not in propriety desire his daughter as a lover, in the same way that Hook could not think of Wendy as being his child. Neither man can in his own right investigate fully those features of his existence that distance him from Wendy and from children in general. However, by combining these two characters behind the face of one actor, the loneliness and isolation of both men with respect to Wendy can be amalgamated without breaking any bounds of social or imaginative acceptability. Through du Maurier's physical conjunction of their separate characters, the implied impact of Hook and Mr Darling in their interactions with Wendy increases substantially. On their own, their means of relating to her are limited. Together, they make demands on each of the three major roles that Barrie gives play in her character.

Of course, Pan's remains the only truly single face which suffers the combined loneliness of the merged roles of his story's adult male leads, and his is the only truly single face that can probe fully the confines of his interactive isolation in a way that his antagonists (because 
of their adulthood) cannot. Pan, we remember, breaks through ${ }^{161}$ the boundary put up by the Darling's nursery window with two things in mind: first, to regain his shadow, and second, to hear the end of Wendy's Cinderella story. Unwittingly, though, Wendy gives him a third agendum, in her response to his suggestion in Peter Pan that he should return with her to Never Land:

Oh dear, I mustn't. Think of mother. Besides, I can't fly. $(P P$, p. 102)

Pan, quick as a flash, follows Wendy's unwitting imperative and thinks of mother, but he thinks of Wendy as his mother rather than of, as Wendy is implying, the feelings of Mrs Darling. Wendy, Pan thinks, can be a mother to him and his Lost Boys, and tell them stories and darn their clothes (as is, as Chris Routh has pointed out, her wont). (CR) Pan wishes Wendy to be his mother. However, the proposition that Wendy would also be returning to Never Land as the mother of the Lost Boys, who are all, in some indefinable yet irreducible way, Pan's as well, puts an uncomfortable strain - highlighted in Act 4 of Peter Pan - on Pan's desire for Wendy's maternity. This move suggests that the roles of Pan and Wendy (Peter and Wendy) with respect to the Lost Boys would become identically parental. By desiring Wendy as a mother, Pan inherently desires her as a partner as well. He makes himself, by implication, into a lover and a father. This logic, to Pan, is unacceptable, for it forces him into the adult sexualized context which he fears and from which he has been barred. The only way for him to escape is to require Wendy to be a forever playful child, in which capacity she can act out the role of a mother without ever troubling him with the possibilities of fatherhood. Yet even this option fails, because Wendy returns to the real world, and is provided with her own ending - out of Pan's control - in which she grows up

\footnotetext{
${ }^{161}$ This term is used quite literally - the first chapter in Peter and Wendy is entitled 'Peter Breaks Through.' $(P W$, p. 69)
} 
and becomes a genuine mother. Pan becomes pushed out of his own story by a developmental inevitability in which he, in his monstrosity, cannot participate. Pan is a Betwixt-and-Between; not exactly a bird, not exactly a human, and - as a result of his inability to control Wendy's interactivity in the manner that he so rigidly tries to regulate his own - not exactly anything.

Pan's conundrum, then, is that he shares identical crises of personal value with the combination of his two adult male adversaries. On a fairly low level, Pan's similarity to $\mathrm{Mr}$ Darling is signalled by his occasional petulance and by his repetition of $\mathrm{Mr}$ Darling's paternal catchphrase. His closeness to Hook, however, is far more acute, and is indicated both explicitly ${ }^{162}$ and implicitly ${ }^{163}$ in Peter Pan's third act, and in the substantial evidence of the stage direction at the point of Hook's demise:

Where is Peter? The incredible boy has apparently forgotten the recent doings, and is sitting on a barrel playing upon his pipes. This may surprise others but does not surprise Hook. Lifting a blunderbuss he strikes forlornly not at the boy but at the barrel, which is hurled across the deck. Peter remains sitting in the air still playing upon his pipes. At this sight the great heart of Hook breaks. That not wholly unheroic figure climbs the bulwarks murmuring 'Floreat Etona,' and prostrates himself into the water, where the crocodile is waiting for him open-mouthed. Hook knows the purpose of this yawning cavity, but after what he has gone through he enters it like one greeting a friend.

The curtain rises to show Peter a very Napoleon on his ship. It must not rise again lest we see him on the poop in Hook's hat and cigars, and with a small iron claw.

$(P P$, p. 146)

After all the play, and all the fun-making triviality, the truth of Peter Pan is that Hook is inside him and of him. And, if Hook is inside Pan, then so too must be Mr Darling, for we have seen that Hook and Mr Darling are demonstrably an imaginative amalgam. Thus, when Pan and Hook attack one another with the words 'proud and insolent youth, prepare to meet thy doom' and 'dark and sinister man, have at thee,' $(P P$, p. 145) the rhetorical and rhythmic

\footnotetext{
162 '[Pan] can imitate the captain's voice so perfectly that even the author has a dizzy feeling that at times he was really Hook.' $(P P$, p. 120)

${ }^{163}$ Hollindale suggests that there is a twinning parallelism between the two characters standing opposite one another on top of Marooners' Rock. (Peter Hollindale, in POP, p. 317)
} 
similarity between the two phrases informs us subtly that their speakers are merely two sides of the same coin. Similarly, when Hook is eventually consumed by the no-longer ticking crocodile (the sound of which has hitherto emblematized the inevitability of passing time which so painfully haunts the pirate captain), Pan has in no sense beaten him. Hook is simply subsumed and assimilated into Pan's character, from which he was never particularly far removed in the first place. Pan, inexorably, becomes that which he hates. The boy who is loved becomes the man who is feared.

\section{(iv) Sewing Pan's Shadow}

The outline of the truth has been tailing both Pan and his audience from the moment that his story begins, and, in this context, du Maurier could not have been more accurate when she referred to her father's interpretation of Hook being like that of 'a dark shadow'. Peter first comes to the Darling's nursery to retrieve his shadow: the insubstantial entity that follows him around, and defines his shape and dimensionality. His shadow is first detached from him by Mrs Darling's defensive snapping down of her children's nursery window, and, through this, the audience is alerted to the fact that there is something unusual going on: 'Peter's shadow is not like that of most other children, because it comes off.' $(K L$, p. 48$)$ It is recorded in Peter and Wendy that 'Mrs Darling examined [Pan's] shadow carefully, but it was quite the ordinary kind.' $(P W, \mathrm{p} .78)$ That a shadow is describable as being ordinary means that there must concomitantly be shadows that are not ordinary. From what we have seen here, a combination of Mr Darling and Hook constitute Pan's not-ordinary shadow. They too are insubstantial entities, inasmuch as they are not linked physically to Pan, but they too define his character's shape and dimensionality. By coming back to the Darlings' to collect the ordinary shadow that he has consciously lost, Pan, unknowingly, is forced to confront the secondary shadow about which he knows very little. The monstrous shade 
hanging over Peter Pan - the silhouette which determinedly haunts him but which he never quite manages to stick on and control - is not that formed by the critically misinterpreted image of his character undergoing authorial manipulation or paedophilic sexual abuse, but is instead that which results from the simple fact that there is nowhere that he can run to hide from himself and what he is. This, in the case of the Peter Pan stories, is the crisis of childhood, or, as Rose would have it, the impossibility of children's fiction. Only by embracing the monstrosity of making oneself impossibly extraordinary - by flying out of the nursery window, by flying away from mother, by flying away from mature interactivity, to a place where one can scream never never never - can the inevitability of that which plagues the image of childhood (the imminence of adulthood) be escaped. However, embodied in the vicious social critique of Pan's character, the Never Land to which one flees is an unreal stasis - an oủtó $\pi l \alpha$ - and its residents become changeless whilst remaining uneasily aware of the existence of change: returning to windows to find them barred; returning to windows beyond which can be seen special people who have moved on in some way and have become irrevocably different. Still, though, the Never Land inhabitant must come back to that which it has not, that which it is not, for to do so is its nature: 'it is, of course, the very definition of Peter Pan that he will always return.' (JR, p. 89) Pan, the innocent, the child, returns continually and monstrously to nursery windows, the symbolic point at which he lost his shadow(s) and his location. He becomes as a result, as Barrie himself has indirectly suggested in his play's dedication to the Llewelyn Davies brothers, a pseudo-Frankensteinian vehicle through which to critique the value system of the society around him. Pan's innocence, his childlikeness, protects him from that which he is and that which he could become, personified in Mr Darling and Captain Hook and their combined adult awareness of an irreducible yet indefinable lack. It seems for Barrie and his characters that, 'so long as children are gay and innocent and heartless' ( $P W$, p. 226) this cycle will continue, as a 
testament not only to the impossibility of children's fiction but also simultaneously to the impossibility of childhood. Only when children have lost their joyfulness and their purity and their carelessness, will adult collapse into child, and shadow collapse into body. Only then will the investigative border-demonstrating monster than is Peter Pan finally die. 
CHAPTER ELEVEN

C.S. LEWIS: YOU DON'T NEED EYES TO SEE, YOU NEED VISION 
In his 'Of Three Ways of Writing for Children' - an essay that, in its first form, he read as a paper to a Library Association conference in Bournemouth in 1952 - C.S. Lewis makes a pivotal declaration about his writing for children. 'Within the species "children's story,", he states, "the sub-species which happened to suit me is the fantasy or (in a loose sense of that word) the fairy tale. ${ }^{164}$ Typically of Lewis, this comment is subtle and precise, and its description of his writing for children is notable almost as much for what it does not say as for what it does. Despite asserting his personal allegiance to the modes of fantasy and fairy, for instance, it does not suggest either that all children's stories are fantastic, or that all fantastic stories are for children. In fact, it does not even associate fantasies and fairy stories with any specific age bracket, since this is a tendency that Lewis regards as a habit of publishers that bears little or no relation to the reading patterns of ordinary readers. Instead, Lewis simply associates fantasies and fairy stories with children and their literature.

With this in mind, it is interesting to note that, throughout 'Of Three Ways,' Lewis represents himself as a childlike (or, by some definitions, an anti-adult) being:

Critics who treat adult as a term of approval, instead of as a merely descriptive term, cannot be adult themselves. To be concerned about being grown up, to admire the grown up because it is grown up, to blush at the suspicion of being childish; these things are the marks of childhood and adolescence. And in childhood and adolescence, they are, in moderation, healthy symptoms. Young things ought to want to grow. But to carry on into middle life or even into early manhood this concern about being adult is a mark of really arrested development. When I was ten, I read fairy stories in secret and would have been ashamed if I had been found doing so. Now that I am fifty I read them openly. When I became a man I put away childish things, including the fear of childishness and the desire to be very grown up.

$(T W$, p. 507)

Thus, for Lewis, fairy stories and fantasies are not literatures for people of a given age, but people of a given mentality. Lewis sees childhood as a phase that provides a foundation which should be added to, rather than demolished, as humans progress through their years,

${ }^{164}$ C.S. Lewis, 'Of Three Ways of Writing for Children,' in C.S. Lewis, Essay Collection and Other Short Pieces, ed. Lesley Walmsley (London: HarperCollinsPublishers, 2000), hereafter EC, 505-15, hereafter $T W$ (p. 506). 
and for those true children who manage such a constructive development, fantasy and fairy should maintain a particular appeal. Notably, Lewis does not here qualify solely in his own terms the features from which this appeal arises, but instead chooses to draw his theories on what constitutes a child- and indeed an adult-loved fairy tale from the work of J.R.R. Tolkien and Carl Jung. These extracts, alongside what Lewis considers to be his own derivative thoughts on the subject, are extensive but illuminating, and are worth quoting in full:

According to Tolkien the appeal of the fairy story lies in the fact that man there most fully exercises his function as "subcreator;" not, as they love to say now, making a "comment upon life" but making, so far as possible, a subordinate world of his own. Since, in Tolkien's view, this is one of man's proper functions, delight naturally arises whenever it is successfully performed. For Jung, fairy tale liberates Archetypes which dwell in the collective unconscious, and when we read a good fairy tale we are obeying the old precept "Know thyself." I would venture to add to this my own theory, not indeed of the Kind as a whole, but of one feature in it: I mean, the presence of beings other than human which yet behave, in varying degrees, humanly: the giants and dwarfs and talking beasts. I believe these to be at least (for they may have many other sources of power and beauty) an admirable hieroglyphic which conveys psychology, types of character, more briefly than novelistic presentation and to readers whom novelistic presentation could not yet reach.

(TW, p. 509)

[Fairy tales are] accused of giving children a false impression of the world they live in. But I think no literature that children could read gives them less of a false impression. I think what profess to be realistic stories for children are far more likely to deceive them. I never expected the real world to be like the fairy tales. I think that I did expect school to be more like the school stories. The fantasies did not deceive me: the school stories did. All stories in which children have adventures and successes are possible, in the sense that they do not break the laws of nature, but almost infinitely improbable, are in more danger than the fairy tales of raising false expectations.

$(T W$, p. 510)

The implications of these passages are striking. To reiterate, fantasies and fairy tales are media that - through their inherent metaphoricity and resultant license to, for example, anthropomorphically personify abstracts - have more potential power to make us know ourselves than equivalent media which purport to represent reality directly. Put more simply, fantasy literature can - for Lewis - be more effective, more real, than realist literature. Lewis 
feels that supposed realism can end up supplying its audience with unachievable longings, because its claims to, and nominal representation of, reality give it a false sense of authenticity. Fantasy media, by comparison, promote greater text-reader reciprocity, because they are known to be and are recognized as fantasy. Their characters, places, and events can be delighted in, empathized with, loved, and loathed, for the very reason that they are all unreal. They stir a longing not for the concrete and unachieveable, but for the other and the imaginative. They give richness, depth, colour, and life. They provide a desire to investigate and a desire to believe.

At the time when he was composing 'Of Three Ways,' Lewis was also midway through the production and publication of his seven-volume Chronicles of Narnia, for the analysis of which 'On Three Ways' has great significance. The Narnia series arguably represents the culmination of one of the modal movements that this thesis has charted across the arc of popular English writing for children, from overt and often reality-based didacticism through to more imaginative and often fantasy-based literature. Unlike The Water-Babies, the Alice series, North Wind, and even the Pan texts, however, the Chronicles provide the first fantasy landscape for children that we have seen to which access is granted directly. As Paul Karkainen observes:

Fantasy is never lazy or unreal in Lewis's books. It is a concrete, tangible thing which, for a time, is more real than the everyday world. Lewis purposely avoided a technique often used to introduce fantasy: the dream. Putting fantasy into a dream would make it appear strictly an inner psychological phenomenon used only to escape from reality, and Lewis does not want to create this impression. ${ }^{165}$

So, Narnia is not entered - in line with the medieval and fantasy traditions used by Tom, Alice, and Diamond - through dreams, trances, or deathly experiences. Nor, even, as in the case of the little Darlings, is it the territory of the night time nursery. Instead, Narnia is a

\footnotetext{
${ }^{165}$ Paul A. Karkainen, Narnia Explored (Old Tappan, New Jersey: Fleming H. Revell Company, 1979), hereafter $N E$, p. 13.
} 
land to be entered with both eyes open, or, perhaps more accurately, with unimpaired vision. It is an unapologetically real unreality. In Lewis' Jungian terms, Narnia is a place to which its child adventurers and its readers go to know themselves, or, reconfigured to the terms of this thesis, it is a place to which its child adventurers and its readers go for enlightenment and revelation. It is, therefore, a place of demonstration. It is a place of monsters.

Another difference between the Chronicles and those texts that have been considered heretofore, is in the great and developed variety amongst the monsters - the creatures that are different - that dwell in and visit Narnia. The Chronicles abound with werewolves, hags, evil spirits, and bad men. They also contain a recurrent wicked female figure, who appears variously as Jadis the Queen of Charn (in The Magician's Nephew), Jadis the White Witch (in The Lion, the Witch, \& the Wardrobe), and the Lady of the Green Kirtle (in The Silver Chair). This woman embodies in one person the original sin of mankind's fall (through her selfish consumption of the divine apple in The Magician's Nephew) and the celestial graspingness of Satan.

Such characters are all, by and large, generic and corrupt monsters, which indicates that there is a discernible and uncomplicated struggle going on throughout these books between the forces of good and evil. To balance this scenario, it is necessary that there should be clear cut forces for good as well, and these are personified in the splendour of the selfsacrificing lord of Narnia, the son of the great Emperor-beyond-the-sea, the terrible yet beautiful Great Lion, Aslan. Aslan, of course, in his numinosity, is every bit a monster too. His physical, spiritual, and rhetorical otherness demonstrate and reveal correctness to those who would lay down their lives to follow him.

To maintain parity with our previous analyses, however, this chapter will not investigate in detail the implications of the sort of monsters detailed above. Instead, it will concentrate on the particularly monstrous properties of three of the human children who enter into Narnia 
during the course of the Chronicles: the Pevensie girls, Lucy and Susan, and their cousin, Eustace Scrubb. Each of these, in this thesis' terms, can be defined as monstrous as a result of their position with respect to Narnia: Lucy lives in it, Eustace grows into it, and Susan falls away from it. As such, they represent different degrees of discipleship (or lack of it) within the cycle of Narnia's life, and they therefore provide exemplars from which child readers - in Lewis' sense - may derive a greater knowledge of themselves. Before commenting on these three characters, however, two of the most contentious and most important areas of extant Narnia scholarship must be examined briefly: the debatable order in which the books should be read and the degree of their relationship to Christianity. Both of these areas cast essential light upon the characters who exist within their parameters, and are therefore necessary precursors to the heart of this chapter.

\section{(i) Chronologizing the Chronicles}

Quoting for substantiation from a variety of Lewis' letters and articles, Jim Pietrusz comments that it is quite obvious the [sic] C.S. Lewis had no intention of writing more than one book when he started the Chronicles of Narnia., ${ }^{166}$ Nevertheless, once Aslan had bounded into the picture, a further six books were eventually written to follow The Lion, the Witch \& the Wardrobe, and the full series was eventually published - one volume per year from 1950 onwards - as The Lion, the Witch \& the Wardrobe, Prince Caspian, The Voyage of the Dawn Treader, The Silver Chair, The Horse and His Boy, The Magician's Nephew, and The Last Battle. However, this sequence does not accord with Narnian chronology, and so the Chronicles can be ordered alternately as The Magician's Nephew, The Lion, the Witch \& the Wardrobe, The Horse and His Boy, ${ }^{167}$ Prince Caspian, The Voyage of the Dawn Treader,

\footnotetext{
${ }^{166} \mathrm{Jim}$ Pietrusz, 'Rites of Passage: The Chronicles of Narnia \& the Seven Sacraments,' Mythlore, 54 (1988), 61-63 (p. 61).

${ }^{167}$ The Horse and His Boy is the only one of the seven Chronicles of Narnia which does not involve the transition to Narnia of people from our world. It is set during the monarchic reign of the four
} 
The Silver Chair, and The Last Battle. To those not acquainted with Lewis' writing, this discrepancy may appear to be a subject merely of academic pedantry, but, to support the work in this area done by Peter Schakel, ${ }^{168}$ it is actually of paramount importance to a logical appreciation of the Chronicles. Schakel records that the second of these two orders is becoming increasingly prevalent, to the extent that some editions of the Chronicles now use it without making any reference to the fact that a different organization exists: 'people who purchase new copies of the Chronicles now may never become aware that The Magician's Nephew was not always treated as Book 1.' (IA, p. 42) In addition to this, recent commentators on the series have begun to make unqualified subjective statements in favour of the Narnian chronological approach, ${ }^{169}$ and even Lewis himself has been cited in a letter as showing a preference for this ordering. ${ }^{170}$

There are, though, as Schakel points out, substantial problems with this methodology: 'to read one of the other books before The Lion, the Witch and the Wardrobe sacrifices strategies that Lewis used to lead readers into the world of Narnia and to help them share imaginatively in the experiences of Lucy, and later the other children, as they discover what that world is like.' (IA, p. 45) This argument is persuasive. If Narnia is entered initially through a route other than the door of the wardrobe that stands in the bare spare room of Professor Kirke's house, then the risk is run of negating the wardrobe's power. If The Magician's Nephew is read before The Lion, the Witch \& the Wardrobe then we cannot participate in Lucy's wonder (in the chronologically later book) at the presence of a lamppost in the middle of a

Pevensies, within the time spanned by the narrative of The Lion, the Witch \& the Wardrobe's final chapter.

${ }^{168}$ Peter J. Schakel, 'The "Correct" Order for Reading the Chronicles of Narnia?,' Mythlore, 88 (2001), 4-14, reprinted as a chapter in Peter J. Schakel, Imagination and the Arts in C.S. Lewis: Journeying to Narnia and Other Worlds (Columbia: University of Missouri Press, 2002), hereafter IA.

${ }^{169}$ Michael Coren refers to the second of our two sequences as 'the best reading order' for the Chronicles. (Michael Coren, The Man Who Created Narnia (Grand Rapids, Michigan: Williams B. Eerdmans Publishing Company, 1994), p. 77)

${ }^{170}$ C.S. Lewis, in $I A$, p. 44. 
snowy forest, for we already know how it arrived there. ${ }^{171}$ Equally, Mr Tumnus' explanation to the puzzled Lucy that she has arrived in Narnia $(L W, \mathrm{pp} .16-7)$ becomes pointless, since we already have a pretty good idea where she is. In effect, such a reading would have filled in advance all the gaps in the reader's knowledge that increases mental closeness to and reciprocity with the exploring character of Lucy, and - as shall be seen - Lucy relies upon this audience proximity as she goes on to fulfil her demonstrative function.

If another example is required to demonstrate the ways in which Narnian chronological readings can problematize the whole of Lewis' series, then it need be sought no further than the narrative's introduction to Narnia's theological epicentre, Aslan. The first time Aslan's name is mentioned in Lewis' published writing is in the words of Mr Beaver, in The Lion, the Witch \& the Wardrobe:

"They say Aslan is on the move - perhaps has already landed."

And now a very curious thing happened. None of the children knew who Aslan was any more than you do; but the moment the Beaver had spoken these words everyone felt quite different... Edmund felt a sensation of mysterious horror. Peter felt suddenly brave and adventurous. Susan felt as if some delicious smell or some delightful strain of music had just floated by her. And Lucy got the feeling you get when you wake up in the morning and realize that it is the beginning of the holidays or the beginning of summer.

$$
(L W, \text { p. 65) }
$$

In this extract, the narrator is directly addressing and drawing the reader in to equivalence with the Pevensies: 'none of the children knew who Aslan was any more than you do.' The reader's relationship with Aslan, therefore, is developed at exactly the same pace as those of the children. From their individual reactions to the palpable textual numinosity of Aslan's name, the reader can not only evaluate the current mental state of Peter, Susan, Edmund, and Lucy, but also begin to draw conclusions about the sort of creature who might have such a name; a creature that makes Peter feel brave, Susan sensually aware, Lucy happy, and

\footnotetext{
171 See C.S. Lewis, The Lion, the Witch \& the Wardrobe: A Story for Children (Harmondsworth: Penguin, 1959), hereafter $L W$, p. 14, and C.S. Lewis, The Magician's Nephew (Harmondsworth: Penguin, 1963), p. 102.
} 
Edmund horrified. The reader learns that Aslan is a lion alongside the Pevensies, $(L W, \mathrm{p} .75)$ and meets him first alongside the Pevensies. $(L W$, p. 115$)$ Each experience is a growth, and part of the mutual development between characters and readers in their respective spiritual understandings of Narnia and its workings.

Again, though, if we were to begin our Narnian exploration with its chronological opening - The Magician's Nephew - then we would be unable to participate in the narrative journey of its chronological successor, because we would have already completed many of its elements. Much of the magic, the development, the progress of The Lion, the Witch \& the Wardrobe stems from the fact that the children and their guides travel towards Aslan, both to meet him and to gain an understanding of him. Knowing him from The Magician's Nephew would negate this process. No longer would we be learning equally with the Pevensies, and no longer would the name of Aslan hold the same degree - the essential degree - of numinous mystery with which it is imbued in The Lion, the Witch \& the Wardrobe. Although beginning with The Magician's Nephew remains satisfactory from the point-ofview of meeting Aslan at Narnia's genesis, and although this too is undoubtedly a deeply spiritual and enlightening experience for those who witness it, it nevertheless breaks apart the narrative pattern of its chronological successor. The Lion, the Witch \& the Wardrobe deliberately leaves gaps in Narnian history, and many of these are filled successfully by a reading of The Magician's Nephew, but - strategically - it is more appropriate that these gaps be filled in afterwards, with The Magician's Nephew acting as a prequel to The Lion, the Witch \& the Wardrobe, rather than the latter acting as a sequel to the former. Outside the order of Lewis' publication, the Narnia books still retain much of their mystery and interest, but many of the narrative effects of the chronologically later books - most notably The Lion, the Witch \& the Wardrobe - must be substantially reduced. 


\section{(ii) The Chronicles of Christianity?}

Narnia's timeframe, though, is not its only troublesome component. The core of its content, or the fabric upon which it is based, makes for an equally weighty bone of academic contention, and once again, although this time in earlier research, Schakel's writing proves to be contextually essential. By way of response to a question frequently asked of Narnia "What does this stand for?"- Schakel replies that the fact that this question is being asked at all 'indicates that the Chronciles [sic] are not being approached as stories which are complete in themselves, but as works dependent on outside information for full meaning. ${ }^{, 172}$ More specifically, Schakel's allusion is to the fact that the Chronicles are most frequently analysed with the presupposition that they comprise focussed Christian allegories, and that he believes that this assumption does not do them justice. In observing this, of course, Schakel does not dismiss from Narnia the presence of its alternate rendering of aspects of Christianity, for to do this would be to defy the obvious. Green and Walter Hooper reach a realistic midpoint summary of this situation, by finding typical Lewisian subtlety in the Chronicles' implicit Christianity: 'the Bible is, of course, [the Chronicles'] basic source book, though most readers, even of mature age, recognize little of it except in Aslan's death and resurrection and Lewis intended it to be recognized only subconsciously. ${ }^{173}$ This comment on Lewis' own perception of Christianity in Narnia is derived from his essay 'Sometimes Fairy Stories May Say Best What's to be Said:'

Some people think I began by asking myself how I could say something about Christianity to children; then fixed on the fairy tale as an instrument; then collected information about child psychology and decided what age-group I'd write for; then drew up a list of basic Christian truths and hammered out "allegories" to embody them. This is all pure moonshine. I couldn't write in that way at all...

\footnotetext{
${ }^{172}$ Peter J. Schakel, Reading with the Heart: The Way into Narnia (Grand Rapids, Michigan: William B. Eerdmans Publishing Company, 1979), hereafter $R H$, p. xi.

${ }^{173}$ Roger Lancelyn Green and Walter Hooper, C.S. Lewis: A Biography (London: Collins, 1974), p. 252.
} 
But supposing that by casting all these things into an imaginary world, stripping them of their stained-glass and Sunday school associations, one could make them for the first time appear in their real potency? Could one not thus steal past those watchful dragons? I thought one could. ${ }^{174}$

In other words, with respect to Narnia, Lewis did not believe that he was manufacturing a framework that claimed rigidly to be Christianity in some sort of fantastical fairy disguise. He was not explicitly trying to rewrite biblical material for a child audience, but was instead presenting certain Christian stories and truisms in a way that posits links between Narnian and Christian theologies, spiritualities, and even celestialities. Karkainen summarizes this brilliantly: 'Aslan does not compete with Christ; he illumines him.' (NE, p. 18)

Nevertheless, though, a number of Lewis' oft-quoted 'watchful dragons' remain firmly at their posts, for there are still many who do not discern the subtlety of this allusively allegorical methodology. Consider, for example, the work of David Holbrook, who has produced one of criticism's simultaneously most convincing and most misleading attacks on Narnia's use of Christianity:

The crux of my argument appears if I open Lewis's Christianity to critical analysis and suggest that his Christ is too severe an authoritarian power to whom one needs masochistically to submit. There are, of course, the problems of submission posed by the Book of Job and the story of Abraham and Isaac. But my problem, if I think about Lewis's version of Christ, is that his representation of Him as Aslan seems too full of magic and the impulse to control. These are not on my part religious doubts, but doubts that arise if I examine his meanings as a creative writer within the Christian tradition. ${ }^{175}$

Holbrook illustrates precisely the problem that Lewis was attempting to resolve in 'Sometimes Fairy Stories' for the true crux of Holbrook's argument revolves around the fact that he believes that, in Narnia, Lewis has written a monotypic Christian allegory. This belief is not correct. Aslan is not Lewis' Christ. Christ is Lewis' Christ. Even describing Aslan as a representation or a version of Christ is inaccurate because this still implies an

\footnotetext{
${ }^{174}$ C.S. Lewis, 'Sometimes Fairy Stories May Say Best What's to be Said,' in $E C, 526-8$ (pp. 527-8).

${ }^{175}$ David Holbrook, The Skeleton in the Wardrobe: C.S. Lewis's Fantasies: A Phenomenological Study (London: Associated University Presses, 1991), hereafter $D H$, p. 11.
} 
explicit comparison between the two which Lewis, particularly in the Narnian texts, never actually makes. ${ }^{176}$ Equally, in the context of stories controlled by Lewis' narrative voice, why should Holbrook have a problem with Aslan being magical? Nothing in the framework of the Narnian stories precludes this possibility, and many of Narnia's features actually reinforce it. And, even if these were overt Christian allegories, Holbrook's idea that the biblical Christ does not on occasion seek to control his subjects - or at least to instruct them in the firmest possible terms (which is more akin to what Aslan does) - simply makes no sense. The New Testament doctrine is certainly one of love and forgiveness, but it is also a doctrine of the strictest discipline. Thus, whilst it would certainly be untrue to say that Lewis is not a writer within the Christian tradition (for he undoubtedly is), this tradition remains the only immediately Christian context presiding over the Chronicles. As was the case with The Water-Babies, Lewis' publishing history clearly produces an expectation amongst certain parts of his readership about the way in which his work will be deployed. That expectation, in terms of the Christian content in Narnia, turns out to be an oversimplification.

As Holbrook proceeds in his analysis, he continues to select events from the Chronicles to disprove and problematize the religious consistency of Lewis' narrative. Particularly, Holbrook homes in on the scene from The Lion, the Witch \& the Wardrobe in which Aslan is nominally crucified:

The author is evidently aware of the problem of how deeply he can disturb his readers. He even says in one place there were "other creatures whom I can't describe because if I did grown-ups would probably not let you read this book." The beastliness of the crowd calling, "Puss, puss! Poor pussy," at the humiliated lion, is evidently intended to call out anger in the child reader - an anger that is later invoked and directed against the evil mob: encouraging them rather to hate them than to forgive them in the spirit of

\footnotetext{
${ }^{176}$ The closest that the Chronicles' ever get to admitting that there could be a direct link between the Aslan of Narnia and some notional equivalent in our world is at the end of The Voyage of the Dawn Treader, when Aslan is sending Edmund and Lucy back to England. "I am [in your world too,]" said Aslan. "But there I have another name. You must learn to know me by that name. This was the very reason why you were brought to Narnia, that by knowing me here for a little, you may know me better there." (C.S. Lewis, The Voyage of the Dawn Treader: A Story for Children (Harmondsworth: Penguin, 1965), hereafter $V D$, p. 209)
} 
"they know not what they do." Under the surface, one detects a seething rage, in which Lewis seeks to involve the child reader.

$$
\text { (DH, pp. 46-7) }
$$

Once again, this is a persuasive reading, but, once again, it is strategically flawed. At no stage does Aslan utter Christ's death-words of forgiveness, and there is no reason therefore for him to be bound by them. As a scene from a book that is written by a man who states that, in writing for children, he is happy to 'let there be wicked kings and beheadings, battles and dungeons, giants and dragons, and let villains be soundly killed at the end,' (TW, p. 512) there is no inconsistency in Aslan's death, resurrection, and contribution to the annihilation of the White Witch's army. The only conceivable contradiction that could be drawn in this would rely upon Aslan actually being Christ, which he is not. Also, on the point about drawing forth anger from the child reader, it would be strange indeed if anger were the only response felt by children at the death of the Aslan. In the great lion's death, there is fear, confusion, and sadness - both for the lion himself and for the children witnessing his demise - as much as there is as anger. And, even if this scene does produce anger, fear, and sadness at the terribleness of wrongful death, these are surely not reasons that make it inappropriate or inconsistent for inclusion in what, from its title, is confessedly 'a story for children.'

The final difficulty in Holbrook's argument which it is necessary to detail here comes in his treatment of Lucy's initial venturing into Narnia:

At the beginning of The Lion, the Witch and the Wardrobe, Lucy has been in the "other" world; but the others do not believe her. What is Lewis's point here? $\mathrm{He}$ obviously believes that it is very important that we recognize the existence of spiritual reality. This is something he aspires to teach us. But is he trying to teach us to be more imaginative, more insightful, or more "religious"? Lucy can easily move between the world of the spirit... and the world of everyday; but those who belong to the world of the common light-of-day are not able to accept reports from that "other" world, and are, indeed, hostile to its recognition.

(DH, p. 32) 
Holbrook is exactly right in his statement that Lucy's is a character through which can be recognized the importance of appreciating spiritual reality, and that she, in line with Lewis' Jungian rendering of the function of fairy tales, might even be being used in the context of the Chronicles as a tool to illuminate or demonstrate fact. Indeed, this summary constitutes an abbreviated version of the selfsame case that this chapter will later make on the subject of Lucy's character. However, by dividing into separate entities the notions of imagination, insightfulness, and religious belief, Holbrook overcomplicates what for Lewis was all partand-parcel of the same thing. If Narnia - as understood by critics such as Karkainen, Green, Hooper, and Schakel - was, for Lewis, a vehicle through which he could demonstrate the critical importance of an open imagination as a precursor to spiritual understanding, then imagination, insightfulness, and religious belief must all be bound up together. One cannot function without the additional presence of the other two. Those who cannot move between the world of the spirit and the world of the everyday must lack at least one of these faculties, and are likely therefore to be hostile or at least resistant to the products of their presence. Edmund, initially, appears to be one such person. So too does Eustace, and so too becomes Susan. Lucy, however, possesses from the outset all three of these faculties, and this makes her Narnia's foremost spiritual child proponent. She is the single embodiment of imagination, insightfulness, and religious belief that Holbrook ironically fails to spot. This is not to say that Lucy is faultless, and Lewis does not pretend that she is, but she is undoubtedly special. For our purposes, Lucy's specialness - her embodiment of Lewis' three spirit-enabling faculties - makes her Narnia's principal monster.

\section{(iii) Lucy}

So, having established that to start at the publicatory beginning is a very good place to start in the case of the Chronicles, and having isolated Lucy as Narnia's principal child monster, 
let us now consider what it is that makes her so from the moment of the Chronicles' outset. To précis, The Lion, The Witch, and the Wardrobe details the story of the four Pevensie siblings, Peter, Susan, Edmund, and Lucy, who are evacuated from their home in wartime London to the house of an old professor who lives in the heart of the country. Therein, during a game of hide-and-seek, Lucy (the youngest of the children) discovers and climbs in to an old wardrobe in a spare room, which leads her in to the magical land of Narnia. After an exciting adventure, in which she meets and has tea with a faun, whom she afterwards has to persuade not to hand her over to Narnia's cruel dictatorial queen, the White Witch, Lucy returns to England through the wardrobe door and runs to find her siblings:

It's - it's a magic wardrobe. There's a wood inside it, and it's snowing, and there's a Faun and a Witch and it's called Narnia; come and see.

$(L W$, pp. 27-8)

Lucy, quite logically, makes a claim for her story based on the assumption that she will be able to substantiate it with empirical evidence, but when the four return together to the spare room, there is nothing for them to see other than the wardrobe's back. Peter, Susan, and Edmund come but they cannot see, their cynicism having first been aroused by Lucy's claim that she has been away for many hours (when for them, no time has passed since she says she has been away). Also, in the minds of their youthful adult realism (children, we remember Lewis pointing out, like to think of themselves as being very adult), countries at the back of wardrobes just do not exist. In fact, to the Pevensies, what Lucy is saying simply cannot be true, and yet we, Lucy's reading audience, know that it is true because we have been to Narnia with her. We have heard her conversation with Mr Tumnus, we have shared their meal together, and we have participated in Mr Tumnus' fear of the terrible White Witch. We know that Peter and Susan are misjudging Lucy, with all the superiority of their elder sibling realism, and that Edmund's malicious fun-poking at her is both unfair and unwarranted. We 
stand beside Lucy, share her shame, share her rejection, share the pain of being the historically truthful child who is now accused - incorrectly - of lying.

What Lewis is doing here is privileging Lucy by setting apart her vision from that of the other children and making her different in some way (the implications of which we can not yet be sure). Lewis is, within the community of the Pevensies, making Lucy into a monster, and asking us to stand in solidarity with her because we know her to be right. It is all too easy to take the cynical attitudes of Peter and Susan, or to adopt the mocking tones of Edmund when faced with a story as fantastical as that which Lucy tells, but we cannot do so in this instance because Lucy - through her difference - has guided us in to Narnia. She has opened a path, which, at least initially, the other children do not understand. Lucy's belief and childlikeness have unlocked a unique opportunity to access a new, wonderful, and almost unbelievable landscape.

Before Peter and Susan can also participate in Narnia, they need a lesson in mature logic and youthful vision. In the face of Lucy's persistent maintenance of her story, their pragmatic realism leads them to conclude that she must be either insane or lying, and the weight of these possibilities eventually pushes so heavily upon them that they take their postulations to their host - the child-adult, Professor Kirke - to seek his advice. He, exasperated at the lack of logic taught at modern schools, calmly puts down their arguments with the radical proposition that Lucy is in fact most likely to be telling the truth (on the empirical evidence that she is not mad, and the historical evidence that she is not a liar ${ }^{177}$ ). ( $L W$, p. 48 ) Kirke's thinking forces Peter and Susan to modify their position with respect to

\footnotetext{
${ }^{177}$ One might argue, if one were thinking of the Narnia series as a whole, that Professor Kirke has very good reason to believe in the reality of Narnia, since he was in attendance at its inception as the boy Digory in The Magician's Nephew. The Pevensies do not yet know this, however, and nor do the children who read the Chronicles in their published order, so this fact becomes another one of Lewis' narrative gaps which is only later filled by supplementary information. At this stage in the Chronicles, Kirke is simply providing a mature voice of reason to convince Peter and Susan that there is nothing essentially wrong with what Lucy is telling them. We, and the Pevensies, only realize the strength of his authority to make such a comment with the benefit of hindsight.
} 
Lucy's account of her travels, and subsequently lessens some of the negative loneliness of her alienating monstrosity ('after this things were a good deal better for Lucy' ( $L W$, p. 50$)$ ). Peter and Susan's shift from adult realism to childlike imagination finally permits them full access to Narnia by lowering their disbelief and incredulity towards their sister. When their adult guard is dropped, by the childlike predicament of needing to hide from Kirke's strict housekeeper Mrs Macready, they climb into the wardrobe out of necessity and without prejudice, and are thus permitted - at a time when they least expect it - to see the wardrobe's true contents.

Lucy's monstrous specialness, though, does not cease at this early stage, but remains in place throughout each of the Chronicles in which she features. Later in The Lion, the Witch, and the Wardrobe, for example, when the three children are journeying towards the great castle of Cair Paravel (remembering that, by this time, Edmund has betrayed his siblings and fallen prey to the wiles of the White Witch), they meet Father Christmas, who gives them all precious gifts. For Peter, there is a sword and shield; the symbols of a warrior and a leader. For Susan, there are a bow and arrows, and a small horn with the sound of which she will always be able to summon help; a weapon to be used from a safe distance and, again, an instrument which indicates calling and leadership. But what does Lucy get?

A little bottle of what looked like glass (but people said afterwards that it was made of diamond)... [in which] "There is a cordial made of the juice of one of the fire-flowers that grow in the mountains of the sun. If you or any of your friends is hurt, a few drops of this will restore them," [said Father Christmas]

$$
\text { (LW, p. 100) }
$$

Lucy's primary gift is a healing cordial, and this, in spite of the fact that she also receives a tiny dagger with which to defend herself if absolutely necessary, clearly distinguishes her from Peter and Susan. Here, Lucy is marked as a healer, an intercessor, and a figure of profound spiritual depth. 
Jumping forward a little further, it is no coincidence that, in Prince Caspian, Lucy is the first of the Pevensies to respond to the pull of Susan's horn on the station from which they are meant soon to be returning to their respective schools. ${ }^{178}$ She too is the first to give voice to the collective sense of queerness felt by all the children as they begin to realize that they have returned not only to Narnia but to the ruins of their castle of Cair Paravel. $(P C$, p. 20$)$ Most importantly in the second book, Lucy is also the first of the four to discern the presence of Aslan on their journey to reach and aid the usurped Caspian against the tyranny of his wicked uncle, King Miraz. ( $P C$, p. 110) Her spiritual closeness to Aslan and Narnia, suggested by the fact that she was the first human in the published series to enter the country's boundaries, is thus confirmed: her demonstrative monstrosity brings her into pronounced proximity, even union, with the demonstrative monstrosity of Aslan. In The Voyage of the Dawn Treader, it is Lucy who sees through the exterior of Eustace's monstrous dragon form (as Aslan later tears it off), and it is Lucy who comforts the boy within - monster to monster, as it were - by kissing his now hideous reptilian face. $(V D, p p$. 88-9) Even at the very end of Narnia's time, at the close of The Last Battle, when faced with a group of incorrigible dwarves whose spiritual impoverishment is so great that they refuse to believe the truth of Aslan's existence when he stands directly before them, Lucy continues to plead for their enlightenment long after everyone else has given up. ${ }^{179}$

Lucy's gifts, then, make her every bit the revealing monster, but, for all the frequent clarity of her spiritual vision, she is no unattainable or distant paragon. Lucy is very much the fallible follower of Aslan, both as a human and as a child. Returning to Prince Caspian-

${ }^{178}$ C.S. Lewis, Prince Caspian: The Return to Narnia (Harmondsworth: Penguin, 1962), hereafter PC, p. 12.

${ }_{179}$ C.S. Lewis, The Last Battle: A Story for Children (Harmondsworth: Penguin, 1964), hereafter LB, pp. 132-4. 
the tale in which, as Don King puts it, Lucy's 'susceptibility to failure is underscored'180 we see Lucy's faith tested to the limit. After their day of rowing towards Caspian's stronghold at Aslan's How, all of the companions except Lucy are exhausted by their ventures. Lucy, however, is very much awake, and walks off into the moonlit forest beside Glasswater Creek. The magical ambience of the light and the coolness and the deliciousness of the open air smells lend to Lucy a sense that she is truly back in the Narnia that she once knew, and she tries to awaken the tree spirits by speaking to them directly. The narrator implies that she is almost successful, but then the magic dies away and the forest returns to normal:

Yet Lucy had the feeling (as you sometimes have when you are trying to remember a name or a date and almost get it, but it vanishes before you really do) that she had just missed something: as if she had spoken to the trees a split second too soon or a split second too late, or used all the right words except one, or put in one word that was just wrong.

Quite suddenly she began to feel tired. She went back to the bivouac, snuggled down between Susan and Peter, and was asleep in a few minutes.

$(P C$, p. 104)

This scene is striking for the rapidity with which Lucy's waking clarity gives way to sleepiness. One moment she is awake and active and doing, and the next - following a nonspecific sense that she had failed to fulfil some part of an indefinable process - she is sound asleep. Her devout wakefulness collapses into physical tiredness, and she returns, as a physical rather than spiritual being, to the physical warmth and comfort of her elder (less faithful) siblings. She has been a privileged witness to an event which approached the beauty of old Narnia, and yet her eyes become clouded to the sacredness around her. She does not see, and she sleeps instead.

${ }^{180}$ Don W. King, 'The Childlike in George MacDonald and C.S. Lewis,' Mythlore, 12 (1986), 17-22, 26, http://cslewis.drzeus.net/papers/childlike.html, hereafter $D K$. Pagination to a physical edition is not provided by the online service from which this essay was downloaded and is therefore not offered here. 
The next day, however, Lucy again re-establishes her specialness and demonstrative power when she sees the face of Aslan trying to guide her, her siblings, and Trumpkin (their dwarf companion) back onto the right path. $(P C$, p. 111) She understands that this is Aslan's purpose, and says as much to the others, but they, with the notable exception of Edmund ${ }^{181}$ in spite of Lucy's previously recognized closeness both to Narnia and to Aslan - do not believe in her with sufficient strength to follow her advice. More to the point, in terms of Lucy, she does not believe in herself (or, by implication, Aslan) with sufficient strength to take the hard decision to leave the group and follow Aslan on her own. Ironically, this (perfectly understandable) act of weakness then forces her into solitude anyway, because she knows once again that she is right and she knows once again that she is not believed: 'and Lucy came last of the party, crying bitterly.' $(P C, \mathrm{p} .113)$

On this occasion, though, Lucy has only a little time to wait before she awakens, both literally and metaphorically, 'out of the deepest sleep you can imagine.' $(P C$, p. 120$)$ The next night, after a day which had brought nothing but trouble because of the group's pursuit of the wrong path, Lucy's eyes are opened, and one of the most affecting scenes in the English children's canon unfolds:

A circle of grass, smooth as a lawn, met her eyes, with dark trees dancing all round it. And then - oh joy! For he was there: the huge Lion, shining white in the moon-light, with his huge black shadow underneath him.

But for the movement of his tail he might have been a stone lion, but Lucy never thought of that. She never stopped to think whether he was a friendly lion or not. She rushed to him. She felt her heart would burst if she lost a moment. And the next thing she knew was that she was kissing him and putting her arms as far round his neck as she could and burying her face in the beautiful rich silkiness of his mane.

"Aslan, Aslan. Dear Aslan," sobbed Lucy. "At last."

$$
(P C, \text { pp. 123-4) }
$$

\footnotetext{
${ }^{181}$ By this point in the series, Edmund has made considerable advancements from the boy that he was in The Lion, the Witch \& the Wardrobe. This may be seen even from the beginning of Prince Caspian, when he is the second of the Pevensies - behind Lucy - to respond to the pull of Susan's magic horn. $(P C$, p. 12) That Edmund now supports instead of vilifies the spiritual vision of Lucy, even though he does not share it, is greatly to his credit, and the significance of his faith's growth is measured by the fact that he sees Aslan before his elder siblings. (PC, pp. 130-1)
} 
Lucy, quite literally, comes home to Aslan as her spiritual lord. Her myopia is cleansed and her faith is renewed. But even now her work is only just beginning, for Aslan implies that he considers the fact that she and the others did not follow him to represent a degree of personal failure on Lucy's part. Lucy is required to return to her sleeping companions, to wake them from their own (literal and metaphorical) slumbers, and to tell them to come immediately and follow Aslan. That they may not believe her, that they may react negatively, and that they may not initially see Aslan, are all irrelevances. What is important is that Lucy fulfils her purpose to follow Aslan as he commands:

It is a terrible thing to have to wake four people, all older than yourself and all very tired, for the purpose of telling them something they probably won't believe and making them do something they certainly won't like. "I mustn't think about it, I must just do it," thought Lucy.

$$
\text { (PC, p. 126) }
$$

The narrator's emphasis on the age differentiation between Lucy and the people that she is waking perpetuates the notion that there remains still a deep visionary discrepancy between age and youth, as the former - in Lewis' terms - rejects the imaginative sight of the latter. Indeed, so great is the divergence between them that age and youth look on the same thing and see it completely differently: the elder children and Trumpkin look at Aslan just as Lucy does, but, at least initially, they cannot see him. Only by trusting in Lucy, the one amongst them who has been privileged by Aslan to act as their (and our) spiritual guide, can the others eventually be led back onto the (literally and metaphorically) correct path (to Caspian and to Aslan, respectively). Only by trusting in Aslan can Lucy be vindicated once more and thus be drawn back into the group whilst remaining true to the faith that she refuses to deny.

Lucy's desire for acceptance, and the conflict which this produces with her faith, troubles her again in The Voyage of the Dawn Treader, but this time in the form of a direct assault by the worldly on her spiritual base. When, relatively late in its journey, the Dawn Treader 
arrives at the island of the Dufflepuds, Lucy is required once more to put her conviction to the test when what appears to be an invisible body of enemies demands that she enter the house of an ostensibly hot-tempered wizard in order to remove the spell which condemns them to invisibility. Enter she does, and discovers the magic book which contains the relevant spell. However, as she turns the pages of the book, and reads the corporeal nature of the spells held in its pages, she becomes increasingly drawn to them, until at last she lights upon 'an infallible spell to make beautiful her that uttereth it beyond the lot of mortals.' (VD, p. 131) Lucy, having never been considered a beauty ('grown-ups thought Susan the pretty one of the family' ( $V D$, p. 10$))$, finds it terribly hard to turn this page and continue forward as she has been requested:

The first [image] was a picture of a girl standing at a reading-desk reading in a huge book. And the girl was dressed exactly like Lucy. In the next picture Lucy (for the girl in the picture was Lucy herself) was standing up with her mouth open and a rather terrible expression on her face, chanting or reciting something. In the third picture the beauty beyond the lot of mortals had come to her. It was strange, considering how small the pictures had looked at first, that the Lucy in the picture now seemed quite as big as the real Lucy; and they looked into each other's eyes and the real Lucy looked away after a few minutes because she was dazzled by the beauty of the other Lucy; though she could still see a sort of likeness to herself in that beautiful face... Then it changed and Lucy, still beautiful beyond the lot or mortals, was back in England. And Susan (who had always been the beauty of the family) came home... The Susan in the picture looked exactly like the real Susan only plainer and with a nasty expression. And Susan was jealous of the dazzling beauty of Lucy, but that didn't matter a bit because no one cared anything about Susan now.

$(V D$, p. 132)

Internally blinded by the alluring possibility of acquiring worldly beauty, the real Lucy misses the clue of her book counterpart's 'rather terrible expression,' and determines to recite the spell: 
But when she looked back at the opening words of the spell, there in the middle of the writing, where she felt quite sure there had been no picture before, she found the great face of a lion, of The Lion, Aslan himself, staring into hers... He was growling and you could see most of his teeth. She became horribly afraid and turned over the page at once.

$(V D$, p. 133)

At perhaps her moment of greatest recorded temptation in the Chronicles, Aslan intervenes directly into Lucy's vision to express his displeasure at her decision. His anger and reproach act upon her far more than do the images of her potential beauty, and she resumes her course of progressing through the book in order to find the spell that she was commissioned to seek. Although she finds other fascinating material, both negative and positive, in the book including an enigmatic spell for the refreshment of the spirit, which turns out to be a story about 'a cup and a sword and a tree and a green hill'182 (VD, p. 135) - nothing again distracts her comparably from her purpose. Aslan has, once again, returned his disciple to the right road.

Throughout the series, then, the consistency of Lucy's role as the one who finds the route to a better path, and who remains steadfast and sure in the face of disbelief, incredulity, cynicism, and vilification, all demonstrate her monstrosity. 'Even though Lewis employs an omniscient narrator, [it is surely significant that] much of what we learn about Narnia comes to us as if through Lucy's eyes.' ( $D K$ ) Lucy's charity, generosity, valour, and deep understanding of the Narnian divine function to confront her readers and peers with questions not only about which of her assets we genuinely share, but also about how we go about treating people like her. Are we incredulous? Are we cynical? Do we disbelieve? Do we mock? Do we see with our eyes or do we see with our vision? Lucy's is a discipleship

\footnotetext{
182 Alongside Aslan's death and resurrection, and his comments at the end of The Voyage of the Dawn Treader, the appearance of this mysteriously refreshing story is another of the Chronicles' strongest, though still subtle, Christian markers (in this instance, through delicate allusion to the Last Supper and Christ's Passion).
} 
against all adversity: in its alienation and frequently revelatory power, it is a perfect representation of the condition of the true monster.

\section{(iv) Eustace}

By comparison, the monstering of Eustace Scrubb is a very different process. Whereas Lucy's alienation and demonstrative function are usually depicted in the positive light of her devotion to Aslan, Eustace's difference is defined initially by his active persecution of Narnia. In this sense, Eustace's monstrosity in The Voyage of the Dawn Treader parallels closely that of his cousin, Edmund, in The Lion, the Witch \& the Wardrobe. The Chronicles' account of both boys begins with their scepticism, their adult love of worldly fripperies, and their spite, before subsequently detailing their respective progressions towards spiritual childlikeness via profound and painful conversion experiences. Here, we will focus upon Eustace rather than Edmund, firstly, for the very reason that their respective monstrosities are very similar (and it therefore seems inappropriate to examine both in detail), and secondly, because the monstrosity of Eustace's conversion - more so than Edmund's - manifests itself upon him physically as well as mentally. Physical distortion is a feature of monstrous discourse that there has been little opportunity to examine in this text, and Eustace presents a viable opportunity to address this imbalance.

The opening of The Voyage of the Dawn Treader reveals Lewis' Narnia narrator at his most implicitly acidic:

There was a boy called Eustace Clarence Scrubb, and he almost deserved it. His parents called him Eustace Clarence and masters called him Scrubb. I can't tell you how his friends spoke to him, for he had none. He didn't call his Father and Mother "Father" and "Mother", but Harold and Alberta. They were very up-to-date and advanced people. They were vegetarians, non-smokers and teetotallers and wore a special kind of underclothes. In their house there was very little furniture and very few clothes on the beds and the windows were always open.

$(V D$, p. 9) 
Without once making an explicit attack on the Scrubbs and their offspring, Lewis establishes them in a single descriptive paragraph as people who are antithetical to Narnian imagination. Amongst a detailed account of their modernity and their faddishness, there is not one direct comment about their spiritual condition. The fact that the narrator can find nothing whatsoever to say on this subject, demonstrates - within the Narnian narrative context - the completeness of the Scrubbs' imaginative impoverishment.

After his arrival on the Dawn Treader, it quickly becomes clear that Eustace is far from well conditioned for Narnian life. His only experience of animals in England has come from the dead ones that he collects, and so wild talking animals like Reepicheep, the mouse, are entirely beyond his ken. The drinking of spiced wine after his unceremonious dunking in the sea is equally unsatisfactory, given that what he feels he should be having is 'Plumptree's Vitaminized Nerve Food [made with] distilled water and anyway he insisted on being put ashore at the next station.' $(V D$, p. 18$)$ Eustace disgusts even the odious Pug, the slave-trader who captures Caspian and his companions when they put ashore from their voyage at the Lone Islands:

"Oh him?" said Pug. "Oh take him and welcome. Glad to have him off my hands. I never see [sic] such a drug in the market in all my born days. Priced him at five crescents in the end and even so nobody'd have him. Threw him in free with other lots and still no one would have him. Wouldn't touch him. Wouldn't look at him. Tacks, bring out Sulky.

$$
(V D, \text { p. 58) }
$$

Eustace, then (like Lucy, although for different reasons), is distanced from and treated with incomprehension by the majority of characters with whom he initially comes into contact. He is selfish, manipulative, petulant, and puny, and he simply cannot comprehend that everything he has been taught about nutrition, economics, and sociology (to name but a few), is absolutely valueless in a world such as Narnia where people eat food that does not come out of packets and resolve their problems without the spite and bickering associated with 
English politics. In Narnian terms, Eustace needs to grow up. He needs to be less of a fabricated adult, and more of an adventurous child.

His opportunity to achieve this arises towards the end of the first half of The Voyage of the Dawn Treader, when he wanders off alone on the first island at which the Dawn Treader moors after leaving the Lone Islands. Typically unprepared for his journey, Eustace gets lost, and soon finds himself at the top of a cliff looking down at a terrifying looking creature that he cannot name - it is actually a dragon - crawling out from its cave to have a drink:

But perhaps if [Eustace] had known something about dragons he would have been a little surprised at this dragon's behaviour. It did not sit up and clap its wings, nor did it shoot out a stream of flame from its mouth. The smoke from its nostrils was like the smoke of a fire that will not last much longer... It moved very slowly towards the pool - slowly and with many pauses. Even in his fear Eustace felt that it was an old, sad creature. He wondered if he dared make a dash for the ascent.

$(V D$, p. 76)

Plainly to the reader, if not also to Eustace, this is a dragon that is dying, but - even through the boy's woeful ignorance of what he is looking at ('Eustace had read none of the right books' $(V D$, pp. 75-6)) - it is important to notice that the narrator does something very new with Eustace's character here. Eustace, in spite of his fear (for himself), feels that the dragon is aged and unhappy. He feels emotion on behalf of another creature - an empathy, over and above his selfishness - which is later found to have been wholly accurate. The dragon is highly likely to have been both old and sad, because we later discover that it was probably once the Lord Octesian, one of the seven missing lords of Narnia, friends of Caspian's father, who were dispatched by Miraz on an exploration of the Eastern Seas from which they never returned. When Eustace first sees the dragon, he knows nothing of this, and yet he still experiences emotional reciprocity with the beast. He recognizes sadness, he recognizes loneliness, and he recognizes agedness. 
Eustace identifies these three traits correctly, of course, because he shares in all of them, even if he does not know it. He is sad because he is lonely, and he is lonely - in terms of Narnia - because he is too adult (too old). As the skies open and rain upon him, Eustace bolts into the dragon's cave and discovers the creature's pile of hoarded treasure. Thinking thoughts of material acquisitiveness, just like a dragon, Eustace - a sad, lonely, aged little boy, who is tired out from his day's adventures - falls asleep on the treasure. And when he wakes up, as an inevitable consequence of his interior mentality, his personality has manifested itself exteriorly, and he discovers a terrible transformation: 'sleeping on a dragon's hoard with greedy, dragonish thoughts in his heart, he had become a dragon himself.' $(V D$, p. 81$)$

This moment, for Eustace, is epiphanic. He now has the power to get even with Caspian, Edmund, Reepicheep, and all the others, for all the wrongs that he perceives that they have done him. And yet, in his new condition, he no longer wants retribution:

He wanted to be friends. He wanted to get back among humans and talk and laugh and share things. He realized that he was a monster cut off from the whole human race. An appalling loneliness came over him. He began to see that the others had not really been fiends at all. He began to wonder if he himself had been such a nice person as he had always supposed. He longed for their voices. He would have been grateful for a kind word even from Reepicheep.

When he thought of this the poor dragon that had been Eustace lifted up its voice and wept. A powerful dragon crying its eyes out under the moon in a deserted valley is a sight and a sound hardly to be imagined.

$$
(V D, \text { p. 83) }
$$

Eustace's physical manifestation of what has hitherto been his character's mental nature gives him immediately a better knowledge of himself. He recognizes that he is lonely (which has always been the case but is now accentuated by circumstance), and his imaginative occlusion begins to disperse. All of the verb constructions in this extract push toward the definition of a new Eustace: 'he realized,' 'he began to see,' 'he began to wonder,' 'he longed for their voices,' 'he would have been grateful.' The monstrous condition of the Lord 
Octesian, transplanted onto Eustace, is serving to monstrate the boy internally, as he, in terms of Narnia, becomes increasingly aware of what is truly important and truly valuable. Worldly acquisitiveness, like the bracelet that he pushed up his arm before going to sleep, only brings him pain and further hunger. Friendship is what is required, and so he goes off in search of it.

Returning to his companions, though, has become very difficult for Eustace, since his physical form has been converted into a type of monster that is normally recognized in fantasy tales as being hostile to most other species. Only after the intercession of the insightful Lucy is Eustace recognized for who he truly is, in spite of his new inability to speak. Eustace's newfound power proves to be of great use to his party, since he can now act as an effective hunter and an effective gatherer of the wood that is so greatly needed to repair the Dawn Treader after its battering in a recent storm. The dragon-monster Eustace is, in fact, much more welcome to the Narnians than the conventional-looking human-monster Eustace, and he begins to feel happier as a result of his help being appreciated. Miraculously, after the Dawn Treader's crew had started to worry seriously about how a dragon would be able to proceed with them on their voyage, Eustace returns to the camp in his human shape, and the reader is told the story of his second metamorphosis as he tells it to Edmund (the boy whose comparable character monstrosity in The Lion, the Witch \& the Wardrobe makes him absolutely the logical person to hear Eustace, even though Eustace does not know this). Eustace's final moment of conversion, from physical and spiritual dragonishness to physical and spiritual childlikeness, came with the arrival of Aslan, who took Eustace away to a garden containing a well. Eustace wanted to bathe in the well to ease the pain of the bracelet on his much swollen arm (the pain of the type of boy that he used once to be), but the lion told him that he must undress before bathing. Eustace understood 
this to mean that must slough his scales, but when he "finally tries to peel off the dragon exterior he finds only the same underneath: ${ }^{183}$

"Then the lion said - but I don't know if it spoke - You will have to let me undress you... The first tear he made was so deep that I thought it had gone right through into my heart. And when he began pulling the skin off, it hurt worse than anything I've ever felt. The only thing that made me able to bear it was just the pleasure of feeling the stuff peel off. You know - if you've ever picked the scab of a sore place. It hurts like billy-oh but it is such fun to see it coming away."

"I know exactly what you mean," said Edmund.

$(V D$, p. 96)

And, of course, in Lewis' meticulous phrasing, Edmund does indeed know exactly what Eustace means. Edmund's experiences during his first time in Narnia - ostracization from his companions before eventual reinstatement with them as a new being - are very similar to those of Eustace. The first tear that Aslan makes into Eustace's skin does indeed go through to the boy's heart, his soul, inasmuch as Aslan has to break away all of the ingrained scaliness with which Eustace has hitherto surrounded himself throughout his life. Aslan must break through Eustace's monstrosity - relieve him, as it were, of the weight of his transgressions - and enable him to walk free. And walk free Eustace does - not, by any stretch of the imagination, as a perfect human, but certainly as one who is much improved. His enhancement is measured finally by the negativity of his mother's response to him at the end of The Voyage of the Dawn Treader, which brings the travel book neatly back to the tone of the paragraph with which it began:

Back in our own world everyone soon started saying how Eustace had improved, and how "You'd never know him for the same boy"; everyone except Aunt Alberta, who said he had become very commonplace and tiresome and it must have been the influence of those Pevensie children.

$(V D$, p. 210)

\footnotetext{
${ }^{183}$ Gregory Wolfe, 'C.S. Lewis's Debt to George MacDonald,' The Bulletin of the New York C.S. Lewis Society, 15.2 (1983), 1-7 (p. 6).
} 
The final Narnian monstrosity that we will consider here culminates at one of the Chronicles' saddest moments:

"Sir," said Tirian [to Peter]... "If I have read the chronicles aright, there should be another. Has not your Majesty two sisters? Where is Queen Susan?"

"My sister Susan," answered Peter shortly and gravely, "is no longer a friend of Narnia."

"Yes," said Eustace, "and whenever you've tried to get her to come and talk about Narnia or do anything about Narnia, she says, 'What wonderful memories you have! Fancy you still thinking about all those funny games we used to play when we were children."”

"Oh Susan!" said Jill, "she's interested in nothing now-a-days except nylons and lipstick and invitations. She always was a jolly sight too keen on being grown-up."

"Grown-up, indeed," said the Lady Polly. "I wish she would grow up. She wasted all her school time wanting to be the age she is now, and she'll waste all the rest of her life trying to stay that age. Her whole idea is to race on to the silliest time of one's life as quick as she can and then stop there as long as she can."

(LB, pp. 123-4)

At the end of Narnia's time, after the brutality of the last battle, all of the humans from our world have arrived at the beginning of the new Narnia, the real Narnia, Aslan's country. All have arrived, except for Susan, and we too, who have read the Chronicles aright, might ask why she has been left out of this final chapter. Response comes in the form of the combined comments of Eustace, Jill, and Polly, which together sound very much like the assessment of arrested development in adults from 'Of Three Ways.' As Paul Ford so tersely has it, at the beginning of his Companion to Narnia, 'throughout the Chronicles, Lewis uses "grown-up" as a synonym for wrong thinking, ${ }^{184}$ and Susan, as Jill puts it, 'always was a jolly sight too keen on being grown-up.'

If we think back to the beginning of the Chronicles, a particular poignancy is given to this character denouement by the fact that Susan has always been a jolly sight too keen on being grown-up. Her exclusion at this final moment - with the benefit of hindsight - cannot

\footnotetext{
${ }^{184}$ Paul D. Ford, Companion to Narnia, 4th edn (New York: Harper San Francisco, 1994), hereafter $P F$, p. 1 .
} 
come as too great a surprise. From the first moment that Susan first steps in to Narnia, she is instantly practical, pragmatic, adult-like:

"Ugh!" said Susan, stamping her feet, "it's pretty cold. What about putting on some of these coats?... I am sure nobody would mind... it isn't as if we wanted to take them out of the house; we shan't take them even out of the wardrobe."

$(L W, \mathrm{p} .54)$

Susan's logic and sense is unquestionable on this occasion, and Lewis - one feels - would not deny either, but her comment nevertheless registers her discourse as being on a different level from that of her siblings. The fact that this discourse intensifies when the children arrive at Mr Tumnus' house and find it ravaged by Maugrim (the werewolf captain of the White Witch's Secret Police), confirms Susan's difference and makes her pronouncedly more problematic:

"I - I wonder if there's any point in going on," said Susan. "I mean, it doesn't seem particularly safe here and it looks as if it won't be much fun either. And it's getting colder every minute, and we've brought nothing to eat. What about just going home?"

$(L W$, p. 57)

These are no longer the words of someone who is solely pragmatic but the words of someone who is bordering on being cowardly:

[Cowardice is] a quality despised by all true Narnians, who value courage. Cowardice is distinguished from fear, which is a feeling, and therefore rational and acceptable. Rather, it is the yielding to the temptation of fear that leads to cowardice, and thus away from the adventure that Aslan sends.

$(P F$, p. 116)

Time and again, following these instigative events in The Lion, the Witch \& the Wardrobe, Susan either yields to her fear or becomes bound up in matters that are immediately practical and that demonstrate little faith. At the beginning of Prince Caspian, when the Pevensies are first whisked back to Cair Paravel, Susan's primary concern is for their lack of food and other 
material essentials. When Lucy makes the suggestion that the door to Cair Paravel's treasure chamber must be close by, and Edmund and Peter determine to look for it, Susan's contribution to the excitement appears both tetchy and petulant:

"Oh, do let's leave it alone," said Susan. "We can try it in the morning. If we've got to spend the night here I don't want an open door at my back and a great big black hole that anything might come out of, besides the draught and the damp. And it'll soon be dark."

$$
(P C, \text { p. 26) }
$$

Susan's greatest failure in Prince Caspian comes very soon afterwards, in her lack of confidence in both Aslan and his messenger.

"Look! Look! Look!" cried Lucy.

"Where? What?" asked everyone.

"The Lion," said Lucy. "Aslan himself. Didn't you see?" Her face had changed completely and her eyes shone.

"Do you really mean -?" began Peter.

"Where do you think you saw him?" asked Susan.

"Don't talk like a grown-up," said Lucy, stamping her foot. "I didn't think I saw him. I saw him."

$$
(P C, \text { pp. 110-1) }
$$

The tone of Susan's voice, revealed as much in Lucy's response to her comment as in Susan's actual wording of it, shows clearly her character's failed development. Her speech here is redolent of something that might have been said by either Edmund or Eustace before their respective conversions. Susan's faith in Aslan is not moving forwards. If anything, it is regressing. When Lucy is later required to wake up all the others to tell them that they must come immediately and follow Aslan, it is Susan who rebels most openly against this proposition, just as it is Susan who is the last to see Aslan on their journey towards Aslan's How. Susan is even the last to feel the pull of the magic horn when it is blown by Caspian in the hope of drawing the Pevensies into Narnia at Prince Caspian's beginning. She is the last 
of the four to hear the sound of her own horn, the great gift given to her by Father Christmas in The Lion, the Witch \& the Wardrobe.

The tremendous sadness of this decline in one of Narnia's High Monarchs is that Susan remains, throughout The Lion, the Witch \& the Wardrobe and Prince Caspian, a good person and a sound follower of Aslan. Equally, though, she is both worldly and fixated upon her notional maturity, and, for these reasons, she eventually shuts herself out from both Narnian discourse and from Narnia. She makes herself into the monster that Edmund was and from which Eustace must escape, and this is confirmed, ironically enough, in a narrative moment that takes place immediately before Eustace starts on the path to his own conversion:

Father had got a job lecturing in America for sixteen weeks that summer, and Mother was to go with him because she hadn't had a real holiday for ten years... It would have cost too much money to take the other three all to America, and Susan had gone. Grown-ups thought her the pretty one of the family and she was no good at school work (though otherwise very old for her age) and Mother said she "would get far more out of a trip to America than the youngsters."

$(V D$, p. 10)

And thus Susan is written out of the Chronicles in which she once figured so prominently. This is the last that is heard of her, other than a brief allusion in The Horse \& His Boy, until Peter's final words of condemnation in The Last Battle. Susan is not even given a chance to voice her own decision, as the narrator takes control of her character and whisks her off to America. Voiceless, alienated from her siblings, and critically shut out from Narnia, Susan is left a very monster. Some critics, like Leonie Caldecott, work hard to find a degree of optimism in this situation:

As for the apostasy of Susan referred to in The Last Battle, it could be argued that, at least, Lewis left room for the action of her free-will, rather than moulding her to conformity with the others. Besides which, since she did not die with the others, her fate is left open. It is not the fact that Susan "grows up" that keeps her out of the Narnian paradise. Her interest in "nylons, lipstick, and invitations" is not what makes her lose her way; it is the fact that she has allowed these (and presumably other things!) 
to over-shadow the sense of wonder and grace that her Narnian experiences might have brought her. ${ }^{185}$

Caldecott's door to Susan's redemption, though, seems an unlikely portal, since Susan's treachery to that which was essential to her childhood - her soul, in Lewis' terms - is utter. Edmund, in The Voyage of the Dawn Treader, claims that he was once a traitor. (VDT, p. 97) If he was a traitor, whilst knowing very little about that which he was betraying, then how much greater is the treachery of Susan, who knows exactly what it is that she is betraying? What Susan rejects in Narnia is what she knows to be the truth, what she has experienced, and what she has been, and yet she still decides to turn her back on it and move instead towards worldly nothingness. She outgrows imaginative reality into the reality of generic adulthood, and becomes a monstrous, disrespected, voiceless, and shut out character as a result.

\section{(vi) On Three Ways of Writing (for) Monsters}

In summary, this examination has considered three of the human children who entered Narnia from our world, and has found that each of the three - in the terms of this thesis - may be thought of as being monstrous. Eustace recedes from his isolated loneliness into the demonstrative power of faith, whilst Susan does the opposite. Lucy stands tall above both, and indeed above all the other children in the books, as the only character who comes into Narnia with the visionary power of true faith. Sight is important in Narnia, and Lucy sees very deeply. What unites all of these children as monsters, and what, if we had here the space to investigate them, would unite many of Narnia's other characters as creatures of comparable effect, is the way in which they relate to the monster which defines their monstrosity: Aslan. True, 'we have seen that it will not do to treat the Narnian stories as if

${ }^{185}$ Leonie Caldecott, 'Narnia - a Taste of Paradise,' The Chesterton Review, 17.3-4 (1991), 415-418 (p. 418). 
they were systematic theology camouflaged as fairy tales, ${ }^{186}$ but it is nevertheless acceptable to reconfigure them as a systematic theology within fairy tales. In other words, Narnia is not a fantasy disguise for a theology transplanted from our world into an illusory fairy tale, but is instead a literary location for a theology which may maintain an allusive relationship to our Christianity but which remains, more importantly, consistent to itself. 'To take the Chronicles as allegory... raises the danger of breaking their spell, either by destroying the independence of the imaginary world, as we begin looking outside it for the completion of its meaning, or by leading us to use our heads rather than our hearts to respond to the stories, or both.' ( $R H$, p. 3) We may, if we choose to do so, see parallels between Narnia's theology and the theologies of our world, but these parallels are not the essence of Narnia. Narnia, through its manifold monsters, is a fantastical exercise not in covert indoctrination but in methodological illumination and demonstration. It posits a way of seeing and a way of living, through the assimilation of which its readers may conveniently be led towards faith. In the words of Clotilde Morhan:

Lewis was not so much interested, in his children's stories, in evangelising his readers to Christianity as he was in the preliminary and necessary phase of awakening their imagination and sensibilities... Lewis is trying to allow some openness in his readers [which he regarded] as indispensable for a possible encounter with the numinous. God takes the initiative of loving us, Lewis believed; man can only ever respond to Him. Yet to be able to respond man first has to be able to see, hear and feel, a capacity which the author thought people had lost. ${ }^{187}$

Quite simply, Narnia, through its monsters, demonstrates. It aims, particularly through Lucy, to enable its child readers - of all ages - to see not with their eyes but with their vision.

\footnotetext{
${ }^{186}$ Walter Hooper, C.S. Lewis: A Companion and Guide (London: HarperCollinsPublishers, 1996), p. 434.

${ }^{187}$ Clotilde Morhan, 'Sacramentalism or the Profane World Revisited: A Study of Lewis's Chronicles of Narnia' (unpublished thesis, Université de Lille III, 1999-2000), p. 5.
} 


\section{CHAPTER TWELVE}

J.K. ROWLING: 'IT IS OUR CHOICES... THAT SHOW US WHAT WE TRULY ARE' 
In the mid-1990s Corgi paperback editions of the Discworld novels by Terry Pratchett, one phrase is repeated consistently in the descriptions of the series' author: 'occasionally he gets accused of literature. ${ }^{188}$ In this statement's naked irony (which snipes at those commentators who attack Pratchett as much for the artistic heresy of his commercial success as for the questionable merits of his writing) are sentiments that may be equally well applied to J.K. Rowling and her Harry Potter books. With one more unpublished volume waiting in the wings to complete Harry Potter's projected septet, and the considerable weight of the Time Warner marketing machine driving forward the various merchandising options associated with it, Rowling's unprecedented publishing phenomenon looks set to continue for at least the remainder of the current decade. This is not necessarily to say that Rowling is a brilliant writer, since it is a given that sizeable revenues and high quality artworks are not inevitably to be found in conjunction with one another. Indeed, the critical arguments over the literary and artistic calibre of Rowling's stories are now as hotly contested as they are persistent. These debates, in their turn, are plagued by manifold inaccuracies, which stem from the fact that Rowling's series is both popular and ongoing. Since there is at present a good deal of financial and intellectual capital to be made from Harry Potter, he tends to encourage the production of immediate and therefore often rushed critical responses.

Given this background of miring fluidity in Rowling's critical context, this chapter will as far as possible avoid getting involved with it. Erroneous and misleading readings of Rowling certainly beg both examination and refutation, but the rapidity with which commentaries on Harry Potter are still being produced would make these processes too irreducible and too tangential for our purposes here. Instead, this analysis will focus - as a logical successor to our discussion of Lewis - on Rowling's interest in her characters' identities and the way in which she uses the notion of choice as a means by which to demonstrate them. It will also

\footnotetext{
${ }^{188}$ See, for example, Terry Pratchett, The Colour of Magic (London: Corgi Books, 1994), p. 3.
} 
privilege the marginalized though essential character of Neville Longbottom to reveal the ways in which a superficially peripheral figure can reveal substantial amounts to, and affect the choices of, his more obviously central counterparts.

\section{(i) Sorting: Making Choices}

From the moment one starts to read Rowling's Harry Potter books, their formulaic titles act as an overt announcement of their interest in the notion of identity: Harry Potter and the Philosopher's Stone, Harry Potter and the Chamber of Secrets, Harry Potter and the Prisoner of Azkaban, etc. Each of these names situates Harry Potter - a named identity conjunctionally alongside an entity that is prefixed by a definite article. The repetitiveness of this structure, which is consistent across each of the books in the series thus far, suggests that there is something in it that is methodologically important to Rowling; that there is something in it that bears repeating. The rational explanation for this looks to be that, in each of her books, Rowling proposes to privilege a character by the name of Harry Potter and that she will do this in conjunction with some sort of designated object, place, person or persons. Reassuringly, on one level, this is exactly what she does. Crucially, however, it is not all that she does, for Rowling's approach to her writing is instead to privilege in it Harry's character in conjunction with all the other characters and contexts which surround him. These are not books that are solely about Harry and some sort of fantastically named entity. Instead, they are about Harry, the manifold complex relationships that he has with the objects, places, and people with whom he interacts, and the process of growing up that results from this interactivity. In fact, in this sense, Rowling's books actually encompass an awful lot.

This might seem a rather self-evident comment to make (inasmuch as it would be difficult to write a bestselling children's book that dealt only with a protagonist and his relationship with one particular thing), but its ramifications are essential to a complete 
understanding of Potterworld. What Rowling has produced in the Harry Potter books is a collection that builds upon, reinforces, and intertwines with itself to form a highly selfreferential and intricate narrative sequence. This facilitates the development of its characters through the processes of them in turn being built upon, reinforced, and intertwined with each other. Harry may well be at the heart of this process, but he is surrounded and defined by a complex group of ever-interacting and ever-evolving peers. It is this interactive definition that most obviously fascinates Rowling, and it is in the choices associated with this that her characters reveal and demonstrate who and what they truly are.

At a thematic level, Rowling's interest in individualities and identities is signalled most clearly in her books' obsession with blood and its ability to define. As The Philosopher's Stone begins, one chapter in a vicious blood war has just concluded. The evil Lord Voldemort - whose purpose it has been, amongst other things, to rid the world of mudbloods (those who are not of pure wizard descent) - has been vanquished mysteriously by his attempt to kill a child: 'Harry Potter - the boy who lived.' ${ }^{189}$ Subsequently, Voldemort's desire for but simultaneous lack of understanding of the initially unexplained power in Harry's blood becomes one of the central features that drive forward Rowling's narratives. A focal instance of this can be found at the denouement of The Philosopher's Stone, when Professor Quirrell - whose body is being inhabited semi-vampirically by Voldemort ${ }^{190}$ attempts to kill Harry. Quirrell is prevented from achieving this aim, however, by agonizing lesions which appear on his infected body wherever it comes into contact with Harry's

189 J.K. Rowling, Harry Potter and the Philosopher's Stone (London: Bloomsbury, 1997), hereafter PS, p. 18.

${ }^{190}$ Voldemort's leech-like exploitation of Quirrell's body is metaphorically vampiric, but Quirrell's vampirism is literal as well, since he steals into the Forbidden Forest (adjacent to Hogwarts, Harry's school) to slaughter unicorns and drink their blood on behalf of his lord. (PS, p. 213) 'It is a monstrous thing, to slay a unicorn... The blood of a unicorn will keep you alive, even if you are an inch from death, but at a terrible price. You have slain something pure and defenceless to save yourself and you will have but a half life, a cursed life, from the moment the blood touches your lips.' (PS, p. 188) Tangentially, it is also worth noting that, at the beginning of The Philosopher's Stone, Quirrell states that he is in London to 'p-pick up a new b-book on vampires.' $(P S$, p. 55$)$ 
skin. ${ }^{191}$ Dumbledore - Harry's apparently (but, it turns out, crucially not) omniscient

headmaster - later explains to Harry that this happens because:

Your mother died to save you. If there is one thing Voldemort cannot understand, it is love. He didn't realise that love as powerful as your mother's for you leaves its own mark. Not a scar, no visible sign... to have been loved so deeply, even though the person who loved us is gone, will give us some protection for ever. It is in your very skin. Quirrell, full of hatred, greed and ambition, sharing his soul with Voldemort, could not touch you for this reason. It was agony to touch a person marked by something so good.

$$
\text { (PS, p. 216) }
$$

Thus, Harry's defence against Voldemort exists in his skin, in his body, and in his blood. It has been passed on to Harry through his mother's love for him, and is inscribed in the very essence of what it is to be identified as Harry Potter. Voldemort later acknowledges that this maternal protection is a powerful counter-curse, and he therefore elects to trap Harry in The Goblet of Fire in order to use some of the boy's blood in a spell to restore his own broken body to full corporeal strength: ${ }^{192}$

The blood of a foe... Wormtail would have had me use any wizard, would you not, Wormtail? Any wizard who had hated me... as so many of them still do. But I knew the one I must use, if I was to rise again, more powerful than I had been when I had fallen. I wanted Harry Potter's blood. I wanted the blood of the one who had stripped

${ }^{191}$ In what could be interpreted as a narrative inconsistency, just before these final moments in The Philosopher's Stone, Rowling's narrator records Harry's disbelief at Quirrell's manifest evil in Harry's recollection that he had 'shaken hands with [Quirrell] in the Leaky Cauldron [public house]' ( $P S, \mathrm{p}$. 211) on the very first day when he had entered the wizard part of London. No explicit mention was made of this handshake when the narrative detailed that earlier meeting, ( $P S$, p. 55) but the retrospective idea that it happened is somewhat peculiar given the effect that Harry's skin later has on Quirrell's. Of course, it is important to remember that Harry's skin only causes Quirrell's to lesion because Quirrell is being inhabited by Voldemort, and The Philosopher's Stone never makes clear beyond doubt the time when Voldemort takes over Quirrell's body. It is, therefore, perfectly plausible that Voldemort was not inside Quirrell at the time of Quirrell's meeting with Harry in the Leaky Cauldron, and thus a handshake between the two at that stage would not have raised any difficulties. By comparison, in chapter 5 of the main feature of the UK widescreen DVD edition of The Philosopher's Stone, Quirrell very pointedly does not shake Harry's hand in the Leaky Cauldron, but instead looks fleetingly fearful and disgusted by Harry's proffered digits. (Chris Columbus, dir., Harry Potter and the Philosopher's Stone (Warner Bros. Pictures: 2002)) For those who do not know Rowling's story before seeing the film of it, this deliberate rejection could easily be understood as an indication of Quirrell's clearly nervous and hypochondriacally high-strung character. For those who know the story, however, the gesture provides a clear-cut nod to their foreknowledge of The Philosopher's Stone's eventual conclusion.

192 J.K. Rowling, Harry Potter and the Goblet of Fire (London: Bloomsbury, 2000), hereafter GF, p. 557. 
me of power thirteen years ago, for the lingering protection his mother once gave him, would then reside in my veins, too...

$$
\text { (GF, pp. 569-70) }
$$

Voldemort claims here to want a part of the protection, the power, that he can see embodied in Harry but which, in his own lovelessness, he cannot understand. Indeed, his spell, once performed, is in part successful. Empowered by his appropriation of Harry's blood, Voldemort becomes able to touch his nemesis, causing immense pain to Harry but none to himself. ( $G F$, p. 566) However, Voldemort's partial understanding once more proves to be his undoing (as it was when he first tried to kill Harry as a baby), because, by mixing his blood with Harry's, Voldemort also succeeds in strengthening the already established bond between them. Throughout The Order of the Phoenix, Harry has fits of seeing through Voldemort's eyes and mind which, though terrifying for him, are a great asset to those who would oppose the Dark Lord's purposes. By the end of The Order of the Phoenix, the bloodbond between these two is immovably confirmed, as Dumbledore recalls to Harry the prophecy of Sybill Trelawney which states that neither Harry nor Voldemort can live whilst the other survives. ${ }^{193}$ The lives of these characters - their essences, their bloods - are beholden and forfeit to one another. Their identities, though they both loathe it, are inherently intermingled.

Further to this cursory inspection, the immediate themes of blood and vampirism in the Harry Potter books have been adequately discussed elsewhere by, amongst others, Suman Gupta $^{194}$ and Gail Grynbaum. ${ }^{195}$ There is no need, therefore, to give them further attention here as individual issues. To reiterate, though, they are important contextual components in Rowling's wider fascination with who and what her characters are, of which the dangerously

\footnotetext{
193 J.K. Rowling, Harry Potter and the Order of the Phoenix (London: Bloomsbury, 2003), hereafter $O P$, p. 741.

${ }_{194}$ Suman Gupta, Re-Reading Harry Potter (Basingstoke, Hampshire: Palgrave Macmillan, 2003), pp. 99-110.

${ }^{195}$ Gail A. Grynbaum, 'The Secrets of Harry Potter,' The San Francisco Jung Institute Library Journal, 19.4 (2001), 17-48 (pp. 26-33).
} 
fluid relationship between Harry and Voldemort provides an excellent illustration. Even before Harry first arrives at Hogwarts, we are already aware of a link between him and his would-be murderer, since Harry is delivered to the Dursleys with a scar on his forehead (a physical sign of Voldemort's failed assault). ( $P S$, p. 17) This connection is plainly restated when Harry enters the shop of Mr Ollivander in London's Diagon Alley in order to buy his first wand: 'holly and phoenix feather, eleven inches, nice and supple.' (PS, p. 65) $\mathrm{Mr}$ Ollivander is intrigued by Harry's wand's choice of Harry as its owner:

I remember every wand I've ever sold, Mr Potter. Every single wand. It so happens that the phoenix whose tail feather is in your wand, gave another feather - just one other. It is very curious indeed that you should be destined for this wand when its brother - why, its brother gave you that scar... The wand chooses the wizard, remember... I think we must expect great things from you, Mr Potter... After all, He Who Must Not Be Named did great things - terrible, yes, but great.

$(P S$, p. 65)

Although Harry's character is not explicitly aware of it at this early stage, there already resonates here the sensation that Rowling's seemingly antithetical characters might in truth turn out to be very close to one another, as - perhaps - different sides of the same coin. Clearly, though, the sides of this particular coin are very different in some essential respects, and a question naturally arises about how one goes about choosing with which side one aligns oneself. Hogwarts' deputy headmistress, Professor McGonagall, provides a preliminary answer to this upon Harry's first arrival at the school:

The start-of-term banquet will begin shortly, but before you take your seats in the Great Hall, you will be sorted into your houses. The Sorting is a very important ceremony because, while you are here, your house will be something like your family within Hogwarts... The four houses are called Gryffindor, Hufflepuff, Ravenclaw and Slytherin. Each house has its own noble history and each has produced outstanding witches and wizards. 
Since Harry has not experienced anything that approximates to familial living during his time with the Dursleys, this opportunity to establish some sense of domestic selfhood by becoming allied to a school house is extremely important to him. The characteristics of the houses - each named after one of Hogwarts' four founders - are initially defined, beyond a few rumours that Harry has heard beforehand, by the song of the Sorting Hat (a talking hat, which looks inside the head of its successive wearers and allocates them subsequently to their new houses):

You might belong in Gryffindor, Where dwell the brave at heart, Their daring, nerve and chivalry Set Gryffindors apart; You might belong in Hufflepuff, Where they are just and loyal, Those patient Hufflepuffs are true And unafraid of toil; Or yet in wise old Ravenclaw, If you've a ready mind, Where those of wit and learning, Will always find their kind;

Or perhaps in Slytherin

You'll make your real friends, Those cunning folk use any means To achieve their ends. (PS, p. 88)

Upon placing the Sorting Hat on their heads, some students are assigned immediately to their appropriate house. Draco Malfoy (an arrogant and moneyed young man from what turns out to be a long line of equally arrogant and moneyed pure-blood wizards), for example, barely has opportunity to get the hat on over his head before it cries out that he should be in Slytherin. Such students, it seems, are made for their houses and vice versa. The choice about the direction in which these students are to go appears to be more-or-less predetermined. Harry, though, proves much more difficult for the hat to sort: 
"Hmm," said a small voice in [Harry's] ear. "Difficult. Very difficult. Plenty of courage, I see. Not a bad mind, either. There's talent, oh my goodness, yes - and a nice thirst to prove yourself, now that's interesting... So where shall I put you?"

Harry gripped the edges of the stool and thought, "Not Slytherin, not Slytherin."

"Not Slytherin, eh?" said the small voice. "Are you sure? You could be great, you know, it's all here in your head, and Slytherin will help you on the way to greatness, no doubt about that - no? Well if you're sure - better be GRYFFINDOR!"

(PS, pp. 91-2)

The hat's emphasis here upon Harry's potential greatness - using exactly the same term previously stressed by Mr Ollivander when describing his expectations for Harry alongside the deeds of the Dark Lord - is no mistake. One can almost imagine the Sorting Hat asking exactly the same questions of the young and still human Voldemort, and him giving the opposite response to Harry's. After all, as Voldemort says at the end of The Philosopher's Stone, he believes that 'there is no good and evil, there is only power.' ( $P S$, p. 211) Harry, by comparison, clearly believes that there are such things as good and evil, and he wants to align himself with goodness. Thus, whilst Voldemort desired greatness and supremacy at the expense of all else, this is a choice that Harry is not prepared to make. Harry chooses to walk away from that path, and is subsequently placed in the care of Gryffindor.

Accordingly, from this one scene and the narrative that leads up to it, Rowling deftly establishes Harry as a character who does not wish to enter the shadiest of the Hogwarts houses ('there's not a single witch or wizard who went bad who wasn't in Slytherin' (PS, p. 62)). She also suggests that an initial choice for students between the paths of good and evil (although those are not terms that Voldemort would recognize) can be reduced to a choice between Gryffindor and Slytherin. This is a powerful act of demonstration (of using previous or current choices to demonstrate who and what a character is), particularly since, as Chantel Lavoie rightly observes, the four Hogwarts houses 'may be equal in theory [but there 
are two that] are "more equal" than the others. ${ }^{196}$ Gryffindor and Slytherin are Rowling's series' rivals, ethically, morally, and in terms of their possession of comparable talents. Even the Hogwarts crest, printed on the title page of each Harry Potter book, ${ }^{197}$ tells of their mutual antipathy: Gryffindor's lion and Slytherin's snake stand opposite each other, seemingly ready to strike, above Hufflepuff's badger and Ravenclaw's raven. Gryffindor and Slytherin oppose one another as groups that are essentially different but in parts the same. They counterbalance each other, like darkness and light, like opposites on a crest, and - to return to this chapter's initial metaphor - like two sides of the same coin.

The Sorting Hat's early emphasis upon Harry's potential for success under the auspices of Slytherin is one that continues to haunt Harry throughout Rowling's first two novels, for it is only at the end of The Chamber of Secrets that Harry is introduced unequivocally to the notion that strength and nobility of identity can derive from choice. True, he has by now exhibited both of these traits in practice, but he still needs to be told explicitly of the theory behind their maintenance in order to be reassured that his identity is as he wishes it to be. In The Chamber of Secrets, Harry's gift of Parseltongue ${ }^{198}$ permits him to hear the murderous voice of the basilisk that hunts its victims by moving through Hogwarts' piping system. The basilisk is under the control of the Heir of Slytherin; a young Voldemort, whose spirit has been stored in the pages of an old diary against the possibility that it might ever need to be re-actualized. ${ }^{199}$ When Harry eventually comes face-to-face with this historical version of

\footnotetext{
${ }^{196}$ Chantel Lavoie, 'Safe as Houses: Sorting and School Houses at Hogwarts,' in Giselle Liza Anatol, ed., Reading Harry Potter: Critical Essays, (London: Praeger, 2003), hereafter GA, 35-49, hereafter $C L$ (p. 36).

${ }_{197}$ See, for example, $P S$, p. 1.

198 Parseltongue is the ability to talk to snakes, commonly associated with both Slytherin and Voldemort, and which Harry first uses without knowledge of its implications in The Philosopher's Stone. (PS, pp. 25-6)

199 This diary, the centrepiece plot component of The Chamber of Secrets, exemplifies the brilliance of Rowling's narrative anticipation and consistency. Seven years after 1998's The Chamber of Secrets, with the publication in 2005 of The Half-Blood Prince, Rowling explains - via Dumbledore - that the diary was one of Voldemort's Horcruxes (magic artefacts in which suitably gifted dark wizards can store fragments of their souls). (J.K. Rowling, Harry Potter and the Half-Blood Prince (London: Bloomsbury, 2005), hereafter $H B$, pp. 471-2)
} 
his arch-enemy, Voldemort partially undermines the boy's growing but fragile sense of self by enumerating the similarities between them:

There are strange likenesses between us, Harry Potter. Even you must have noticed. Both half-bloods, orphans, raised by Muggles. Probably the only two Parselmouths to come to Hogwarts since the great Slytherin himself. We even look something alike... ${ }^{200}$

Comments like this create an embedded drag on Harry's identity, as if the weight of history is pulling him towards a dark side in which he does not want to participate. His character delicate, nervous, teenage - is not robust enough to defend itself against such an open onslaught upon its integrity. 'Lord Voldemort is very much the father of lies' (CL, p. 42) writes Lavoie correctly, and Voldemort is also the ultimate transgressor of social and societal conventions, yet Harry too spends much of his time at Hogwarts lying and bending the school rules to the point of unacceptability. The parallels between the two characters are obvious and, for Harry, terrifying. Are he and Voldemort really any different?

The answer, of course, is that they are, because Voldemort, in speeches like that quoted above, only shows Harry one side of a binary opposition; one side of the figurative coin that they so clearly share. The truth is blurrier than this black and white bipolarity, and returns again to that essential feature of Harry's life that the sorcerer cannot see and cannot understand. Harry has chosen, of his own free will, to be not like Voldemort. Despite the Sorting Hat's reiteration from earlier in The Chamber of Secrets that Harry 'would have done well in Slytherin,' (CS, p. 155) his initial choice at his Sorting has taken him from that path and directed him, albeit not at his explicit request, towards Gryffindor. It was not important to Harry that he was put in Gryffindor. What was important was that he was not put in Slytherin. To give the Sorting Hat its due, Harry probably would have done well in

\footnotetext{
${ }^{200}$ J.K. Rowling, Harry Potter and the Chamber of Secrets (London: Bloomsbury, 1998), hereafter CS, p. 233.
} 
Slytherin, but he would also surely have brought credit to Hufflepuff or Ravenclaw as well. To say, therefore, that he would have done well in Slytherin is a Voldemortish black and white comment that is markedly economical with the truth. Harry, as a true Gryffindor, in his final battle in The Chamber of Secrets, can withdraw Gryffindor's sword from the Sorting Hat as a tool with which to kill Slytherin's basilisk. The basilisk and the sword, the respective weapons of Slytherin and Gryffindor under the control of the heirs apparent of their respective houses, do battle here as the extreme representatives of evil and good. How one arrives at these extremities is deeply complicated, and there are many forks along the roads to them. As Dumbledore later says, though, in his summing up of the events of The Chamber of Secrets, 'it is our choices, Harry, that show us what we truly are.' (CS, p. 245) It is in what is shown, what is chosen, and what is demonstrated that identity can be found. It is, in the terms of this thesis, in the type of monster that a character elects to be.

The complexity and murkiness of choice, however, dictates that what we truly are, and indeed what J.K. Rowling's characters truly are, can often turn out to be quite surprising. Harry is Rowling's hero and Voldemort is her villain, and their choices reveal them as such. This equation, in spite of Harry's fears about himself and what he is to become, is quite straightforward. However, as Quirrell says, upon Harry's discovery that it has been Quirrell under Voldemort's control who has been the true villain throughout The Philosopher's Stone, 'who would suspect p-p-poor st-stammering P-Professor Quirrell?' (PS, p. 209) This is a really pertinent question, especially since it is the sort of enquiry that Rowling's narrative effectively tells us that we should be making from the book's beginning. Why do we not suspect Professor Quirrell? Why do we not countenance the idea that Potterworld might be more complex and more illusory that it appears to be at face value? After all, as Emily 
Griesinger points out, it is obvious from the outset that 'nothing in the Hogwarts world is exactly as it seems: ${ }^{201}$

There were a hundred and forty-two staircases at Hogwarts: wide, sweeping ones; narrow, rickety ones; some that led somewhere different on a Friday; some with a vanishing step halfway up that you had to remember to jump. Then there were doors that wouldn't open unless you asked politely, or tickled them in exactly the right place, and doors that weren't really doors at all, but solid walls just pretending. It was also very hard to remember where anything was, because it all seemed to move around a lot. The people in the portraits kept going to visit each other and Harry was sure the coats of armour could walk.

(PS, p. 98)

If the building within which Harry learns his magic is so mischievously deceitful and contrary, then why too should those who operate in it not be comparably so? The former acts as a metaphor for and a method of drawing attention to the latter, since there are plenty of characters in Rowling's novels who disguise their real nature from their counterparts. The rat Scabbers, who later proves to be the figurative rat, Peter Pettigrew, certainly disguises his true identity throughout the series' first three books. Likewise Barty Crouch junior, one of Voldemort's most loyal Death Eaters, takes on the form of Professor Mad-Eye Moody for a whole school year for the sake of ensuring that Harry gets delivered into the hands of the Dark Lord at the end of The Goblet of Fire. Even Professor Snape, the head of Slytherin house and one of the most unswervingly loathsome characters in the entire sequence, persistently turns out to be on the side of good, in spite of the narrative's best efforts to convince us of the contrary.

Choices, then, may show what characters truly are, but the choices of those characters and the reasoning behind them need not necessarily be immediately apparent. Nor indeed does the making of one choice automatically exclude a counter-choice in the future. Snape is the series' most fully developed example of this latter phenomenon. In The Goblet of Fire, it

\footnotetext{
${ }^{201}$ Emily Griesinger, 'Harry Potter and the "Deeper Magic": Narrating Hope in Children's Literature,' Christianity and Literature, 51.3 (2002), 455-480 (p.463).
} 
is revealed that, in addition to being a Slytherin, Snape was also at one time a Death Eater. However, prior to Voldemort's fall from power, Snape chose, at great personal risk, to turn spy against the Dark Lord and align himself with the goodness of Dumbledore. $(G F$, p. 513$)$ Snape chose to re-identify himself and remake himself, despite the fact that - by the end of The Half-Blood Prince in particular - this fundamental choice to favour goodness looks as though it will carry him towards a multitude of bitter ends.

By comparison, a (currently) lesser character who seems to be moving in the opposite direction, in terms of allegiance, is Percy Weasley, the obsessive pen pusher and careerist bureaucrat of his otherwise likable family. Throughout The Goblet of Fire and The Order of the Phoenix, Percy increasingly opts to stand alongside those in the Ministry of Magic who are in wilful denial of Voldemort's return. ${ }^{202}$ Even though Percy was a Gryffindor (like the rest of his family) during his time at Hogwarts, his power-craving actions in Rowling's latest three books are anything but the courageous actions of a traditional Gryffindor. They are, in fact, much more in line with the serpentine self-serving that is associated with those from Slytherin. The path of Percy's character is getting increasingly dark.

In short, and by way of conclusion to this broad investigation of Rowling's interest in her characters' identities, it would seem that the primary lesson to be taken away from the Harry Potter series is that it is truly dangerous to judge (both metaphorical and literal) books by their covers. ${ }^{203}$ What may at one moment appear to exemplify objective evil may later turn

\footnotetext{
${ }^{202}$ The Ministry's initial practice of denying the evidence of Voldemort's return is epitomized in the actions of Cornelius Fudge, the more-than-appropriately surnamed Minister for Magic, against whose blinkeredness Dumbledore rails at the end of The Goblet of Fire: 'You are blinded... by the love of the office you hold, Cornelius! You place too much importance, and you always have done, on the socalled purity of blood! You fail to recognise that it matters not what someone is born, but what they grow to be!' $(G F$, p. 615) Once again, the emphasis on blood here is unmistakable, as Dumbledore implies that Fudge is blighted by his inability to appreciate people for what they truly are rather than what they are supposedly born to be.

${ }^{203}$ This is deeply ironic, because Rowling's books are now available inside a wide assortment of covers, including some which are designed specifically to make the novels look like adult rather than children's literature. The fact that there is a market for this multiplicity suggests that the Harry Potter series is very much being judged by its covers, and that some of those who read it fear that they will be judged by their association with it.
} 
out to be either evil or good, or indeed a difficult combination of both (as in the case of Snape). In fact, given that Rowling herself is a writer, her novels contain a tremendous number of warnings - both coded and otherwise - against trusting the authority of what is seen, especially when it is seen on the printed page. Veronica Schanoes has written superbly on this subject, and says contextually of Snape that:

[Rowling] forces her reader to think beyond herself and her private identification with Harry to develop an awareness of the alliances necessary in order to do the right thing. This kind of distinction is one that few texts produced for adult consumption make; Shakespeare may remind us that a man may smile and smile and yet be villain, but there is no corresponding line saying that a man may go out of his way to humiliate us and yet be a hero. ${ }^{204}$

In other words, the evidence that is seen - no matter how dependable it appears to be - may well only tell an incomplete version of a whole story. Snape is believed to be a villain because he is cruel to Harry, and yet he consistently turns out to be working - albeit in a troublingly malign and occasionally confused way - for the greater good. By comparison, Sirius Black is eventually believed to be a good man because he turns out to be Harry's wronged godfather, and yet, before all the finer points of his story get sorted out, he manages to break Ron's leg. (PA, p. 246) In addition to these, the series also offers the reader example after example of places in which books and writing cause considerable difficulties: Hermione, brilliant witch though she indisputably is, is tremendously beholden and occasionally blinded by her bookish knowledge; Gilderoy Lockhart, the Defence Against the Dark Arts tutor in The Chamber of Secrets, has published endless accounts of his daring exploits, all of which are merely tales that he has leeched (vampirically, one might say) from other people; Ginny Weasley, Ron's little sister, falls victim to the spirit of the young Voldemort contained in the Dark Lord's aforementioned diary; Rita Skeeter, The Daily

\footnotetext{
204 Veronica L. Schanoes, 'Cruel Heroes and Treacherous Texts: Educating the Reader in Moral Complexity and Critical Reading in J.K. Rowling's Harry Potter Books,' in GA, 131-45 (p. 132).
} 
Prophet's shape-shifting reporter, uses Quick-Quotes Quills to manipulate the stories that she is told into barely recognizable tabloid variations upon the theme of the truth. Rowling encourages this mistrust as part of her call and response narrative movement, by positing questions and markers about her characters before asking her readers whether they will (mis)judge her characters with or without possession of the full facts.

\section{(ii) Sorted: Choices Made}

The child character to whose identity misjudgement accrues most clearly, and whose alienated monstrosity amongst Rowling's child protagonists is developed most effectively, is Neville Longbottom. In spite of his character's frequent narrative peripherality, Neville consistently provides a vital barometer for the stages of development and appreciation that have been reached both by Rowling's characters and by her readers. Neville is initially introduced during the children's first journey onboard Hogwarts Express, when his tearful face pokes into Ron and Harry's compartment to enquire whether or not they have seen his toad. Planning ahead as ever, Rowling has already prescribed a response to this question even before it is asked, by establishing in her previous chapter the stigma that having a toad as a familiar would bring through Hagrid's helpful advice to Harry on his choice of pet: 'not a toad, toads went outta fashion years ago, yeh'd be laughed at.' (PS, p. 62) To reinforce this perception, Ron is swift to condemn Neville's desperation to find Trevor:

"Don't know why he's so bothered," said Ron. "If I'd brought a toad I'd lose it as quick as I could."

Ron is hardly one to talk, as he himself readily acknowledges, since all he has for a pet is a rather dilapidated and sleepy rat (about whose dual existence there is as yet no hint, other than the fact that Scabbers has had a much longer life than a typical rat). Very soon 
afterwards, though, toad-owning Neville manages to consolidate his position by making a complete fool of himself in front of the whole school by forgetting to take off the Sorting Hat after it puts him into Gryffindor. The pattern of his school career is thus established, even before it has had a chance to properly begin.

Extrapolating from Rowling's sensitivity to the naming of her characters, ${ }^{205}$ John Granger proposes that Neville's seemingly inescapably tragedy and pathos can be found inscribed even within his name:

Neville's name points to his "nobody" status. Neville breaks down to ne, meaning "no" or "not", and ville, "villa" or "village", for a sum of "no-place" or "no-where". Longbottom gives us long, "big in size or duration in time", and bottom, "butt" or "lowest place", for a composite of either "big butt" or "long time at bottom of heap". Every day he answers to a name meaning "nowhere-man big-butt/low caste". How appropriate that Harry tells Stan Shunpike while hiding on the Knight bus that his name is Neville Longbottom - it's a great name for an unassuming alias. ${ }^{206}$

Although the gist of Granger's reduction is correct, Neville's clumsiness and poor standard of work means that he is often anything but the unassuming nobody that he on occasion seems so desperate to be. He certainly manages to draw sufficient attention to himself to ensure that he is regularly bullied. Snape, predictably, takes an instant dislike to him and treats him with even more contempt than he uses towards the rest of the Gryffindors, with the result that Neville becomes even more ineffectual than usual in Snape's Potions lessons. Even McGonagall, Gryffindor's head of house, has moments when she condemns Neville with a ferocity that is beyond her more usual mild severity:

\footnotetext{
${ }^{205}$ Were there more space here to explore this particular trait in Rowling's writing then it would undoubtedly merit discussion, particularly as a contributor to the way in which Rowling builds up her characters' identities. However, given that there is already a substantial body of critical material on this subject, it seems more sensible here to provide pertinent references to select places in which it is studied more particularly. For further information on it, therefore, see Jessy Randall, 'Wizard Words: The Literary, Latin, and Lexical Origins of Harry Potter's Vocabulary,' Verbatim, 26.2 (2001), 1-7; 'Larry King Live: J.K. Rowling Discusses the Surprising Success of Harry Potter,' CNN Transcript, http://transcripts.cnn.com/transcripts/0010/20/1kl.00.html; and The Harry Potter Lexicon, http://www.hp-lexicon.org.

${ }^{206}$ John Granger, The Hidden Key to Harry Potter: Understanding the Meaning, Genius, and Popularity of Joanne Rowling's Harry Potter Novels (Port Hadlock, WA: Zossima Press, 2002), p. 297.
} 
"Which person," [McGonagall] said, her voice shaking, "which abysmally foolish person wrote down this week's passwords and left them lying around?"207

Even if it were not known already that Neville had perpetrated this crime as a result of his forgetfulness, there is only one person in the Gryffindor dorm who answers to the title of abysmally stupid:

There was utter silence, broken by the smallest of terrified squeaks. Neville Longbottom, trembling from head to fluffy-slippered toes, raised his hand slowly into the air.

$$
\text { (PA, p. 198) }
$$

Neville Longbottom, then, from nomenclature to person, is every bit the school monster. He is not intelligent, he is not good looking, and he does not fit in. He is the archetypal social outcast. However, remembering that he is a character in a book by Rowling, and that Rowling is an author who has a particular flair for writing characters to whom there is more than may at first meet the eye, there are two questions which need to be asked of Neville, even before the end of The Philosopher's Stone. First, why is such a sad and pathetic little specimen sorted into Gryffindor, the house of the brave? Second, why is his home with his grandmother and not his mother? The ramifications of these two questions are extremely important, and are worth emphasizing in particular because there is no obvious reason to consider them until after their answers have been brutally presented. Here again is another instance in which Rowling distracts her readers from the whole truth by blinding us with only one aspect of it. The data required to ask these questions is presented and sporadically restated from approximately halfway through The Philosopher's Stone, and yet, as a result of Neville's peripherality, we are unlikely to use that data appropriately to query Neville's

\footnotetext{
${ }^{207}$ J.K. Rowling, Harry Potter and the Prisoner of Azkaban (London: Bloomsbury, 1999), hereafter $P A$, p. 198. This provides another example of the problems associated with the written word. Neville has written down the passwords to the Gryffindor common room, because he keeps on forgetting them, but - once on paper - they become a dangerous and treacherous commodity. In the wrong hands, in The Prisoner of Azkaban, Neville's penned passwords almost lead to an in-house murder.
} 
character. Neville, we are encouraged to believe, from his concretising introduction alongside Trevor and the Sorting Hat, is and always will be just Neville. He looks small. He looks insignificant. He looks pointless.

Appearances, however, can be profoundly deceptive, and, to prove the point, let us consider the second of our Neville-related questions: why is this boy's home with his grandmother and not his mother? The fact that Neville lives with his grandmother is established early in The Philosopher's Stone, but Rowling never really encourages us to consider why this should be. Paradoxically, the narrative offers plenty of information about this paragon of a woman. Her Howler ${ }^{208}$ response to the news that her grandson had left the Gryffindor common-room passwords lying around on a scrap of paper (later to be found by the then still thought-to-be-psychotic Sirius Black) could hardly draw more attention to her. She, quite literally in this instance, howls - nothing could suggest more clearly that this lady is a character to be emphasized - and yet the ultimate question of why she features so prominently in Neville's life passes by without even a thought.

But why such an upbringing? Where are Neville's parents? And why do these questions not get considered until after Rowling presents the cruel answers to them? The reason for this last is that none of the other characters considers them either, and Rowling's presentation of Neville's character is careful to make us treat him with the same thoughtlessness that he receives from his peers. Like children, we see poor Neville as inept, inefficient, and a figure of fun, and we circumnavigate a more mature cognitive approach of trying to analyse why he is like this. It takes Dumbledore to eventually reveal Neville's life story to Harry in the latter half of The Goblet Of Fire:

[Neville's] father, Frank, was an Auror... He and his wife were tortured for information about Voldemort's whereabouts after he lost his powers... They are insane. They are

\footnotetext{
${ }^{208}$ A Howler, in Rowling's narrative, is a particular sort of letter that is delivered in anger as a punishment to the addressee. It screams when it is opened but will explode if it is left closed.
} 
both in St Mungo's Hospital for Magical Maladies and Injuries. I believe Neville visits them, with his grandmother, during the holidays. They do not recognise him.

$(G F$, p. 523)

We, like Harry, are suddenly hit by the whole truth:

Harry sat there, horror-struck. He had never known... never, in four years, bothered to find out.

$(G F$, p. 523)

Now, alongside Harry, our opinion of Neville undergoes a rapid change in order to accommodate this new and appalling news: he no longer appears as an irresponsible blundering fool because his awkwardness and daftness can be excused by his heritage. The cruelty of Neville's truth is compounded in The Order of the Phoenix, when Harry and his friends accidentally bump in to Neville at St Mungo's whilst visiting Ron's injured father:

Neville's mother had come edging down the ward in her nightdress... Her face was thin and worn now, her eyes seemed overlarge and her hair, which had turned white, was wispy and dead-looking. She did not seem to want to speak, or perhaps she was not able to, but she made timid motions towards Neville, holding something in her outstretched hand.

“Again?" said Mrs Longbottom, sounding slightly weary. "Very well, Alice dear, very well - Neville, take it, whatever it is."

But Neville had already stretched out his hand, into which his mother dropped an empty Drooble's Best Blowing Gum wrapper.

"Very nice, dear," said Neville's grandmother in a falsely cheery voice, patting his mother on the shoulder.

But Neville said quietly, "Thanks, Mum."

His mother tottered away, back up the ward, humming to herself. Neville looked around at the others, his expression defiant, as though daring them to laugh, but Harry did not think he'd ever found anything less funny in his life.

$(O P, \mathrm{pp} .454-5)$

This truth, the whole truth, of Neville's life hurts. It hurts Harry, it hurts Neville, it hurts their friends, and it hurts those who read about it. Nevertheless, Neville's truth directly answers our second question, about why he is living with his grandmother: clearly there are very good reasons for his domestic arrangements. Perhaps more importantly, however, it 
also answers indirectly our first question, which pushes more to the core of who and what Neville is. In the combined genes of Frank and Alice Longbottom, there is considerable bravery. Both were Aurors at the time when Voldemort was at his strongest and both lost their minds in the fight against his evil. Neville's mind too may have been broken to an extent by his parents' fate, and he may have been reduced because of it, but - as with Harry Rowling quickly presents (albeit subtle) evidence that the Sorting Hat was right to place Neville into Gryffindor. At the end of The Philosopher's Stone, Dumbledore hands out a number of house points to Gryffindor to celebrate the defeat of Voldemort by the combined efforts of Harry, Ron, and Hermione. Before the three managed to leave the Gryffindor dormitory to embark upon their quest, however, they were challenged by Neville, since Harry's rule-bending had recently lost Gryffindor a substantial number of house points and Neville did not wish to see his house further denigrated. Hermione, regretfully, stunned Neville, and left him prone on the floor of the Gryffindor common room. (PS, pp. 198-9). At the time, this event (like Neville himself) appears incidental, but after Dumbledore awards his points to Harry, Ron, and Hermione - which brings Gryffindor to a tie with Slytherin for the annual House Cup - he in turn stuns the assembled students with the following words:

There are all kinds of courage... It takes a great deal of bravery to stand up to our enemies, but just as much to stand up to our friends. I therefore award ten points to $\mathrm{Mr}$ Neville Longbottom.

$$
\text { (PS, p. 221) }
$$

It is Neville, therefore - not Harry, not Ron, not Hermione, but Neville - who wins the House Cup for Gryffindor in his first year at Hogwarts. It is poor lonely Neville, who finds the courage - the demonstrative and demonstrable courage - to do and be rewarded for what he believes to be right. He is, after all, a true Gryffindor. He, like Harry, finds his true home in Hogwarts. 
This occasion, long before Rowling details the torture of Neville's parents, allows us to reconfigure slightly our perception of his character, and, as the series moves on, Rowling includes reminder events to ensure that our approach to Neville does not at any time revert entirely to its initially encouraged simplicity. It is Neville who is the first to face and defeat the Boggart used in a Defence Against the Dark Arts lesson given by Professor Lupin. (PA, pp. 103-5) It is Neville, alongside Hermione, who shows most promise in the illegal Defence Against the Dark Arts group that Harry and Hermione co-organise in The Order of the Phoenix. (OP, p. 488) It is Neville who stands alongside Harry and his friends in the fight against the Death Eaters at the conclusion of The Order of the Phoenix. His true bravery, his true position in Gryffindor, can now no longer be in any doubt. Nevertheless, even allowing for all these achievements and all this progress, it is only at the end of The Order of the Phoenix - in the by now routine end-of-book Dumbledore debriefing - that an indication is made of what Neville's future could have been. In the story of The Order of the Phoenix, Voldemort's attention is gripped by a desire to retrieve an object - that remains unspecified for most of the book - that is hidden in Department of Mysteries at the Ministry of Magic. This item, when Harry eventually finds it, bears the legend:

S.P.T. to A.P.W.B.D.

Dark Lord

and (?)Harry Potter

$$
(O P, \text { p. 688) }
$$

The initials in this extract are those of Trelawney and Dumbledore, respectively. Although Trelawney is recognized, in the main, to be a fraudulent seer, this object - a glass ball contains a record of one of her only two recorded true predictions. Its full contents, known only to Dumbledore, tell that:

The one with the power to vanquish the Dark Lord approaches... born to those who have thrice defied him, born as the seventh month dies... and the Dark Lord will mark 
him as his equal, but he will have power the Dark Lord knows not... and either must die at the hand of the other for neither can live while the other survives... the one with the power to vanquish the Dark Lord will be born as the seventh month dies...

$(O P$, p. 741$)$

This prophecy was made sixteen years ago and Harry is the person to whom it most obviously refers, but:

"The odd thing, Harry," [Dumbledore] said softly, "is that it may not have meant you at all. Sybill's prophecy could have applied to two wizard boys, both born at the end of July that year, both of whom had parents in the Order of the Phoenix, both sets of parents having narrowly escaped Voldemort three times. One, of course, was you. The other was Neville Longbottom."

$$
(O P, \text { p. 742) }
$$

In truth, Dumbledore believes the applicability of Trelawney's prophecy to Neville to be no more than a coincidence, since the child that Voldemort went after sixteen years ago was Harry and not Neville. Harry also bears a scar from Voldemort's attack, which fulfils the prophecy's requirement for the Dark Lord's nemesis to be marked by him as his equal. Quite clearly, it is Harry and not Neville who is Rowling's hero. After all, it is Harry who provides the named identity with which all of Rowling's books are titled.

\section{(iii) Sorted?}

Nevertheless, to reiterate, although Rowling's books claim to focus on Harry, they do so only in the context of the other characters by whom he is surrounded. Those characters, particularly those who are difficult and monstrous, contribute not only to the richness of Rowling's narrative landscape but also to the roundedness and fullness of her ostensibly most important protagonist. In the monstrosity and the loneliness of Neville, for example, Rowling encourages us as readers to look beyond what is obvious to establish instead what is real. Neville posits one reality - that of the chubby and unattractive school-child who is a bit simple and who will never amount to anything - and then shatters it by becoming an 
awkward minor hero who stands alongside Harry and who could even in theory have taken Harry's place. Neville is a character that we are encouraged to reject as daft but who amounts to more than we could possibly have conceived initially. He makes his choice. His choice is to be a Gryffindor. This choice shows what he truly is, and it shows in part what Harry is as well (in that Harry is prepared to accept Neville on these terms).

True to form, though, at the end of The Half-Blood Prince, Rowling concludes her penultimate book with a character conundrum. Snape kills Dumbledore, and ostensibly rejects the values of the Order of the Phoenix in order to return to the dark security of the Death Eaters. The second chapter of the book prepares us for this outcome, by detailing a conversation in which Bellatrix Lestrange, her sister Narcissa Malfoy (mother of Draco), and Snape discuss the fate of Draco. Voldemort has given Draco a terrible duty to perform and Narcissa is desperate for Draco to be protected from this task: she fears that he will be killed during its execution. Snape swears an Unbreakable Vow that he will watch over and protect Draco, as well as take over from Draco if it appears that the boy will fail to realize Voldemort's decree. (HB, pp. 37-41) This Unbreakable Vow is highly significant, since the image of it taking place - two hands joined to one another, surrounded by lashes of flame - is depicted on the inside of the dustcover of the UK Bloomsbury first edition of The Half-Blood Prince. Clearly there is something here which we are being told to look out for, and that something materializes at the time when Dumbledore is eventually murdered. This deed, at first glance, transfers Snape back to the evil of Voldemort, since it appears impossible that anything good or right can come from Dumbledore's death. Perhaps this appearance is correct and needs no further elaboration, but, since this is the previously unspoken event which the Unbreakable Vow incident has told us to watch carefully, it is surely notable that Snape's killing of Dumbledore does not merely satisfy the wishes of Voldemort. It also fulfils Narcissa's maternal pleas to Snape on behalf of her son, and it fulfils Dumbledore's 
final desire that Draco should not be permitted to become a killer. (HB, pp. 546-56) Additionally, killing Dumbledore provides Snape with the ultimate obedience offering to give to Voldemort, whilst actually (in some way which is not yet clear) affording him the opportunity to continue to work against the Dark Lord. Thus, assuming that these mitigating postulations are correct, when Snape screams 'DON'T... CALL ME COWARD!' (HB, p. 564) as he runs away from Harry, there is perhaps a greater significance to his exclamation than Harry knows or credits. The intrigue of this situation is that Snape's choices are as yet unclear. It is not clear what sort of a monster - for a monster he undoubtedly is - Snape will turn out to be. We do not and we cannot yet know who he truly is. 


\section{CONCLUSION}

'I THINK LOTS OF KIDS LIKE MONSTERS' 
On $30^{\text {th }}$ October 2005, John Pridmore - Rector of St John-at-Hackney, East London preached a sermon on the subject of modern myths of good and evil at St Martin-in-theFields, Trafalgar Square. This address embodies absolutely what this project has sought to achieve, albeit in subtly different language. The essence of Pridmore's sermon is that 'the great myths, ancient and modern ${ }^{, 209}$ are true (tell the truth) because they represent and embody unassailable moral laws of right and wrong. Being confronted by these laws - the truth - demands that we make decisions about which of their two alternatives we stand alongside, and these decisions in turn demand that we take subsequent choices between options that often seem for us to be bad on the one hand yet even worse on the other. Attempting to discern the correct path in such situations can be appallingly hard, but attempt discernment it we must. 'There's a war on,' Pridmore says, 'and there are no neutrals. We must decide which side we're on.' (JP)

The feature that makes Pridmore's discourse so especially pertinent here is that the modern myths to which it refers are all - with the debatable exception of The Lord of the Rings - popular English children's stories created by popular English children's writers. Three of Pridmore's five named authors - MacDonald, Lewis, and Rowling - have had instances of their work discussed in detail here (exactly the same instances as those analysed by Pridmore, in fact, in the case of Lewis and Rowling). Pridmore also refers to MacDonald as the writer of the first of the modern myths of good and evil, just as this thesis cites MacDonald as the most significant of the three authors who imaginatively exploded the primarily didactic model of pre-1860 English children's literature. Of Pridmore's other two identified writers, Philip Pullman and J.R.R. Tolkien, Pullman's His Dark Materials nominally if not exclusively a children's series - was researched in detail for inclusion in this

\footnotetext{
209 John Pridmore, 'Modern Myths of Good \& Evil,' St Martin in the Fields - Church, http://www2.stmartin-in-the-fields.org/page/church/sermons/Oct \%2030\%2005\%20JP.pdf, hereafter $J P$. Pagination to a physical edition is not provided by the online service from which this sermon was downloaded and is therefore not offered here.
} 
project and was only eventually excised from it due to space constraints. Even Tolkien, whose work was not seriously considered for deployment here, has undoubtedly contributed much to the twentieth-century children's canon through The Hobbit (and, arguably, The Lord of the Rings).

There is, then, a marked consistency of substance between the content of Pridmore's sermon and the content of this thesis, with the exception that Pridmore refers to modern myths where we have referred to children's literature. Why though should this consistency exist, since Pridmore's overarching topic is good and evil whereas this thesis' focus is the notion of monstrosity? Does this mean that these subjects actually have an inherent link after all? Initially, in our first chapter's analysis of Goetsch and Graham, we concluded that monsters themselves could not be defined solely in terms of good and evil. Monsters show through disturbance - that is how they work - but the act of disturbing does not necessarily make the disturber either good or evil. However, what if that which monsters show through their disturbance is inherently to do with good and evil; is inherently to do with right and wrong? What then?

This, surely, is the question that Barker is implicitly asking when he blasts the MPAA for telling him 'you can't make the monsters the good guys.' ( $C B$, p. 323) He wanted to make the monsters in Nightbreed problematic emblems of a better lifestyle based around community and mutual respect, but was told that doing this would incur untold difficulties for his film. Who, then, in this story, become the contextual good guys: the monsters that look evil or the people who reject them (both on- and off-screen) without investigation? What does the MPAA's attitude towards Barker's monsters show about its perceptions of good and evil; right and wrong? Is it, Barker's Nightbreed monsters ask, more evil to look abnormal and be a part of a community of misfits or to look normal and vilify those who do not? 
Questions like these inhabit the very fabric of children's literature, because - as we have seen - writing for children is a literary activity that was born from or at least developed alongside material that was confessedly educational and designed to instruct. At the heart of the educational intention must be the fundamental dialogue between good and evil, for that is what education and instruction are ultimately about: the demonstration to and subsequent inculcation in those being educated of notions of right and wrong, or, more fundamentally, good and evil. Day's Tommy Merton, Trimmer's Edward Jenkins, Carroll's Alice, Barrie's Peter Pan, and Rowling's Neville Longbottom, are all - amongst others and regardless of their own (lack of) merits - indubitably recognizable as monstrous beings. They operate demonstratively, as isolated characters, to challenge their audience's notions of normalcy, right and wrong, good and evil. Such figures make us think again, as Pridmore has it, 'about how things are [and]... about how things should be.' $(J P)$ They, and the books in which they appear, challenge, subvert, and embody manifestos for social change:

Whatever else they are, these "modern myths" are not "escapist." We may find them fun but if that's all we find them we've not been paying attention! They are far too disturbing. They make us think again about how things are. Go to King's Cross Station today and you'll see that between platform nine and ten there's a sign saying Platform 93/4. As you look at that sign - just for a moment, before that sometimes misleading thing called "commonsense" kicks in - you'll wonder. Just for a moment but what an important moment it is! - the frontier between two worlds, the magical and the mundane, fades. That's what these books do for us; it's how they work; it's one reason why they're so important. They make us wonder whether everything is quite as it seems.

They make us wonder whether everything is quite as it seems indeed, for there can be few things so well guaranteed to disturb a subject's perception of normalcy as those things that challenge that subject's understanding of right and wrong. Our notions of right and wrong go to the very heart of who we are, and those things which attack them concomitantly threaten our very identities. This is the dilemma that plagues Barbauld's Lessons for 
Children and gives rise to Sherwood's narrative excesses in The Fairchild Family. This is the crisis that isolates MacDonald's Diamond and melds the characters of Peter Pan and Captain Hook. This is the terrible possibility that leaves us, at the time of writing, unable to know Rowling's Snape, because his character's demonstrative actions force us re-engage with our own perceptions of right and wrong, and how they could potentially be perverted by circumstance. This, in all its monstrous multiplicity and complexity, is what children's literature is about.

Accordingly, Marina Warner could not have been more accurate when she asserts that children - through their paradoxically simultaneous proximity to and distance from contemporary adults - have 'never before[...] been so saturated with all the power of projected monstrousness to excite repulsion - and even terror. ${ }^{, 210}$ In making indeterminate adults' ability to self-determine, children do indeed become terrifying. And yet, of course, the fact that they are so belongs not to the children themselves but to the adults that they affect; belongs not to the perceived but to the perceivers. Adults create their monster children: little not-of-the-self selves that detract from adult identity by acting as symbols of newness which inevitably (if tangentially) draw attention to adult decline. This is why 'at the heart of these modern myths there is an aching longing for things to change...; [why] in their different ways they all look forward.' $(J P)$ Young people represent the future - the need to look forward - as well as the inexorable passing by of what has been. As a result, stewardship over them - stewardship over the future - remains an issue of inheritance and continuance at the core of which are the fundamental (and, for Pridmore, objective) notions of right and wrong. Against such an imperative context, as Rowan Williams puts it, there is and can never be 'any real possibility of wholly "safe" literature" 211 for children:

\footnotetext{
${ }^{210}$ Marina Warner, Managing Monsters: Six Myths of Our Time (London: Vintage, 1994), p. 43.

211 Rowan Williams, On Christian Theology (Oxford: Blackwell Publishers, 2000), hereafter CT, p. 278.
} 
Reading is and ought to be - for adults as well as children - an experience in which acceptable and unacceptable images and proposals crowd upon us together... There are circumstances in which we ought to be very wary of exposing children to certain images; but if we are really interested not in preserving a child's supposedly innocent awareness but in an effective change of relations in society at large, a degree of sceptical detachment about the literature issue will probably do no harm.

$(C T$, p. 279)

Thus, for Williams, it appears that children's literature should not be restricted to an abstract social construction of sanitized acceptability, but should instead be permitted to represent the problematic, the divergent, and the unacceptable; those things which embody the ongoing war between good and evil. In doing this, children's literature will represent children (the problematic, the divergent, and the unacceptable): it will be involved with its projected audience and their needs and wants as little monsters. It will, in short, represent itself. 


\section{BIBLIOGRAPHY: PRIMARY MATERIAL}

[BARBAULD, ANNA LAETITIA,] Hymns in Prose for Children by the Author of Lessons for Children (London: [printed for] J. Johnson, 1781).

[BARBAULD, ANNA LAETITIA,] Lessons for Children, from Two to Three Years Old (London: [printed for] J. Johnson, 1787).

[BARBAULD, ANNA LAETITIA,] Lessons for Children, of Three Years Old. Part I [II], 2 vols (Dublin: R. Jackson, 1779).

ARISTOTLE, Poetics, ed. Stephen Halliwell, trans. Stephen Halliwell / LONGINUS, On the Sublime, trans. W.H. Fyfe, rev. Donald Russell / DEMETRIUS, On Style, ed. Doreen C. Innes, trans. Doreen C. Innes, $2^{\text {nd }}$ edn (Cambridge, Massachusetts: Harvard University Press, 1995).

ASHFIELD, ANDREW, \& PETER DE BOLLA, ed., The Sublime: A Reader in British Eighteenth-Century Aesthetic Theory (Cambridge: Cambridge University Press, 1996).

BARBAULD, ANNA LAETITIA, The Poems of Anna Letitia Barbauld, ed. William McCarthy \& Elizabeth Kraft (Athens: The University of Georgia Press, 1994).

BARRIE, J.M., Peter Pan and Other Plays, ed. Peter Hollindale (Oxford: Oxford University Press, 1995).

BARRIE, J.M., Peter Pan in Kensington Gardens \& Peter and Wendy, ed. Peter Hollindale (Oxford: Oxford University Press, 1991).

BOSWELL, JAMES, \& SAMUEL JOHNSON, Boswell's Life of Johnson Together with Boswell's Journal of a Tour to the Hebrides and Johnson's Diary of a Journey into North Wales, ed. George Birkbeck Hill, rev. L.F. Powell, 6 vols (Oxford: Clarendon Press, 1934).

BURKE, EDMUND, "A Philosophical Enquiry into the Origin of Our Ideas of the Sublime and Beautiful" and Other Pre-Revolutionary Writings, ed. David Womersley (London: Penguin Books, 1998).

CARROLL, LEWIS, Alice in Wonderland, ed. Donald J. Gray (New York: W.W. Norton \& Company, 1992).

CARROLL, LEWIS, Alice's Adventures in Wonderland; Through the Looking-Glass, ed. Roger Lancelyn Green (Oxford: Oxford University Press, 1998).

CARROLL, LEWIS, Lewis Carroll and the House of Macmillan, ed. Morton N. Cohen \& Anita Gandolfo (Cambridge: Cambridge University Press, 1987).

CARROLL, LEWIS, The Annotated Alice: Alice's Adventures in Wonderland and Through the Looking-Glass, ed. Martin Gardner, rev. edn (London: Penguin Books, 1970).

CARROLL, LEWIS, The Complete Works of Lewis Carroll, intro. Alexander Woollcott (London: The Nonesuch Press, 1939). 
CARROLL, LEWIS, The Letters of Lewis Carroll, ed. Morton N. Cohen \& Roger Lancelyn Green, 2 vols (London: Macmillan, 1979).

COLERIDGE, SAMUEL TAYLOR, Collected Letters of Samuel Taylor Coleridge, ed. Earl Leslie Griggs, 6 vols (Oxford: Clarendon Press, 1956).

COLERIDGE, SAMUEL TAYLOR, Samuel Taylor Coleridge, ed. H.J. Jackson (Oxford: Oxford University Press, 1985).

COLUMBUS, CHRIS, dir., Harry Potter and the Philosopher's Stone (Warner Bros. Pictures: 2002).

DAY, THOMAS, The History of Sandford and Merton, 2 vols (Dublin: [printed for] P. Byrne, 1787).

DAY, THOMAS, The History of Sandford and Merton, $5^{\text {th }}$ edn, 3 vols (London: [printed for] John Stockdale, 1790).

DAY, THOMAS, The History of Sandford and Merton, corrected and revised by Cecil Hartley (London: George Routledge and Sons, n.d.).

DAY, THOMAS, The History of Sandford and Merton, Moral and Instructive Entertainment for Young People (London: John Kendrick, n.d.).

EDGEWORTH, MARIA, Letters for Literary Ladies, ed. Claire Connolly (London: J.M. Dent, 1993).

EDGEWORTH, RICHARD LOVELL, \& MARIA EDGEWORTH, Memoirs of Richard Lovell Edgeworth, Esq., 2 vols (London: [printed for] R. Hunter, 1820).

FREUD, SIGMUND, Collected Papers, Authorized Translation Under the Supervision of Joan Riviere, 5 vols (London: The Hogarth Press, 1950).

GAIMAN, NEIL, Coraline (London: Bloomsbury Publishing, 2002).

HOFFMANN, E.T.A., "The Golden Pot" and Other Tales, trans. Ritchie Robertson (Oxford: Oxford University Press, 1992).

KANT, IMMANUEL, Critique of the Power of Judgment, ed. Paul Guyer, trans. Paul Guyer \& Eric Matthews (Cambridge: Cambridge University Press, 2000).

KINGSLEY, CHARLES, The Water-Babies, ed. Brian Alderson (Oxford: Oxford University Press, 1995).

KINGSLEY, CHARLES, The Water-Babies: A Fairy Tale for a Land-Baby (abridged) (London: Puffin Books, 1994).

LAMB, CHARLES, \& MARY LAMB, The Letters of Charles and Mary Lamb, ed. E.V. Lucas, 3 vols (London: J.M. Dent \& Sons, 1935).

LEWIS, C.S., Essay Collection and Other Short Pieces, ed. Lesley Walmsley (London: HarperCollins Publishers, 2000). 
LEWIS, C.S., Prince Caspian: The Return to Narnia (Harmondsworth: Penguin, 1962).

LEWIS, C.S., The Horse and His Boy (Harmondsworth: Penguin, 1965).

LEWIS, C.S., The Last Battle: A Story for Children (Harmondsworth: Penguin, 1964).

LEWIS, C.S., The Lion, the Witch \& the Wardrobe: A Story for Children (Harmondsworth: Penguin, 1959).

LEWIS, C.S., The Magician's Nephew (Harmondsworth: Penguin, 1963).

LEWIS, C.S., The Silver Chair (Harmondsworth: Penguin, 1965).

LEWIS, C.S., The Voyage of the Dawn Treader: A Story for Children (Harmondsworth: Penguin, 1965).

LOCKE, JOHN, "Some Thoughts Concerning Education" and "Of the Conduct of the Understanding," ed. Ruth W. Grant \& Nathan Tarcov (Indianapolis: Hackett Publishing Company, 1996).

LOCKE, JOHN, The Educational Writings of John Locke, ed. James L. Axtell (Cambridge: Cambridge University Press, 1968).

MACDONALD, GEORGE, At the Back of the North Wind / The Princess and The Goblin / The Princess and Curdie (London: Octopus Books, 1979).

MACDONALD, GREVILLE, Reminiscences of a Specialist (London: George Allen \& Unwin Ltd, 1932).

MILTON, JOHN, John Milton, ed. Stephen Orgel \& Jonathan Goldberg (Oxford: Oxford University Press, 1991).

MORE, HANNAH, Cheap Repository Tracts, Published During the Year [1795 / 1796], 2 vols (London, Bath, Edinburgh: J. Marshall, S. Hazard, J. Elder, n.d.).

MORE, HANNAH, Selected Writings of Hannah More, ed. Robert Hole (London: William Pickering, 1996).

POE, EDGAR ALlAN, The Collected Tales and Poems of Edgar Allan Poe (New York: Modern Library, 1992).

PRATCHETT, TERRY, The Colour of Magic (London: Corgi Books, 1994).

PRIESTLEY, JOSEPH, Autobiography of Joseph Priestley: Memoirs Written by Himself / An Account of Further Discoveries in Air, intr. Jack Lindsay (Bath: Adams \& Dart, 1970).

PULLMAN, PHILIP, His Dark Materials (London: Scholastic, 2001).

PULLMAN, PHILIP, Lyra's Oxford (Oxford: David Fickling Books, 2003).

RICHARDSON, SAMUEL, Pamela, ed. P. Sabor (London: Penguin, 1980). 
ROUSSEAU, JEAN-JACQUES, Emile or On Education, trans. Allan Bloom (New York: Basic Books Inc., 1979).

ROUSSEAU, JEAN-JACQUES, Émile, trans. Barbara Foxley (London: J.M. Dent, 1993).

ROWLING, J.K., Harry Potter and the Chamber of Secrets (London: Bloomsbury, 1998).

ROWLING, J.K., Harry Potter and the Goblet of Fire (London: Bloomsbury, 2000).

ROWLING, J.K., Harry Potter and the Half-Blood Prince (London: Bloomsbury, 2005).

ROWLING, J.K., Harry Potter and the Order of the Phoenix (London: Bloomsbury, 2003).

ROWLING, J.K., Harry Potter and the Philosopher's Stone (London: Bloomsbury, 1997).

ROWLING, J.K., Harry Potter and the Prisoner of Azkaban (London: Bloomsbury, 1999).

SHAKESPEARE, WILLIAM, William Shakespeare: The Complete Works, ed. Stanley Wells, et al. (Oxford: Clarendon Press, 1988).

SHELLEY, MARY, Frankenstein. 1818 Text, ed. Marilyn Butler (Oxford: Oxford University Press, 1994).

SHERWOOD, MARY MARTHA, The Fairchild Family, ed. Mary E. Palgrave (London: Wells, Gardner, Darton \& Co., 1902).

SHERWOOD, MARY MARTHA, The History of the Fairchild Family; or, the Child's Manual: Being a Collection of Stories Calculated to Shew the Importance of a Religious Education (London: [printed for] J. Hatchard, 1818).

SHERWOOD, MARY MARTHA, The Life of Mrs. Sherwood, (Chiefly Autobiographical) with Extracts from Mr. Sherwood's Journal During His Imprisonment in France and Residence in India, ed. Sophia Kelly (London: Darton \& Co., 1854).

STOKER, BRAM, Dracula (London: Puffin Books, 1986).

TRIMMER, SARAH, Fabulous Histories: Designed for the Instruction of Children; Respecting Their Treatment of Animals (London: [printed for] J. Longman, et al., 1786).

TRIMMER, SARAH, New and Comprehensive Lessons (London: [printed for] J. Harris, 1814).

TRIMMER, SARAH, Reflections Upon the Education of Children in Charity Schools (London: [printed for] T. Longman, J. \& F. Rivington, 1792).

TRIMMER, SARAH, The Guardian of Education: A Periodical Work, intro. Matthew Grenby, 5 vols (Bristol / Tokyo: Thoemmes Press / Edition Synapse, 2002).

WALPOLE, HORACE, et al., Four Gothic Novels: The Castle of Otranto; Vathek; The Monk; Frankenstein (Oxford: Oxford University Press, 1994).

WORDSWORTH, WILLIAM, William Wordsworth, ed. Stephen Gill (Oxford: Oxford University Press, 1984). 


\section{BIBLIOGRAPHY: SECONDARY MATERIAL:}

ADAMS, GILLIAN, 'Student Responses to Alice in Wonderland and At the Back of the North Wind,' Children's Literature Association Quarterly, 10 (1985), 6-9.

ALEXANDER, PETER, 'Logic and the Humour of Lewis Carroll,' Proceedings of the Leeds Philosophical and Literary Society (Literary and Historical Section), 6.8 (1951), 551-66.

ALLER, SUSAN BIVER, J.M. Barrie: The Magic Behind Peter Pan (Minneapolis: Lerner Publications Company, 1994).

ANATOL, GISELLE LIZA, ed., Reading Harry Potter: Critical Essays, (London: Praeger, 2003).

ANON., 'ART. XI. Poems. By Miss Aikin. 4 to 6s. sewed. Johnson. 1773,' Monthly Review, 48 (Jan. 1773), 54-9.

ANON., 'ART. XI. Poems. By Miss Aikin, concluded: See our last Month's Review,' Monthly Review, 48 (Feb. 1773), 133-7.

ANON., 'A Forgotten Children's Book,' The Hibbert Journal, 63 (1964-5), 27-34.

ANON., The Harry Potter Lexicon, http://www.hp-lexicon.org

ARIÈS, PHILIPPE, Centuries of Childhood, trans. Robert Baldick (London: Jonathan Cape, 1962).

ARMITT, LUCIE, Theorising the Fantastic (London: Arnold, 1996).

ASHPLANT, T.G., \& ADRIAN WILSON, 'Present-Centred History and the Problem of Historical Knowledge,' The Historical Journal, 31.2 (1988), 253-74.

AUDEN, W.H., Forewords and Afterwords, selected by Edward Mendelson (London: Faber \& Faber, 1973).

AUERBACH, NINA, 'Alice and Wonderland: A Curious Child,' Victorian Studies, 17 (1973), 31-47.

BACH, SHELDON, 'Narcissism, Continuity and the Uncanny', International Journal of Psycho-Analysis, 56 (1975), 77-86.

BANERJEE, JACQUELINE, Through the Northern Gate: Childhood and Growing Up in British Fiction, 1719-1901 (New York: Peter Lang, 1996).

BARKER-BENFIELD, G.J., The Culture of Sensibility: Sex and Society in EighteenthCentury Britain (Chicago: University of Chicago Press, 1992).

BARNETT, GEORGE L., "That Cursed Barbauld Crew" or Charles Lamb and Children's Literature,' The Charles Lamb Bulletin, 25 (1979), 1-18.

BEER, GILLIAN, 'Kingsley: Pebbles on the Shore,' The Listener (17 ${ }^{\text {th }}$ April 1975), 506-7. 
BERGER, PAULA SILVERMAN, 'Peter Pan as a Mythical Figure,' (unpublished doctoral thesis, University of Chicago, 1994).

BHATTACHARYA, NANDINI, 'Maternal Plots, Colonialist Fictions: Colonial Pedagogy in Mary Martha Sherwood's Children's Stories,' Nineteenth-Century Contexts, 23 (2001), 381-415.

BILLONE, AMY, 'The Boy Who Lived: From Carroll's Alice and Barrie's Peter Pan to Rowling's Harry Potter,' Children's Literature, 32 (2004), 178-202.

BIRD, ANNE-MARIE, "Without Contraries is no Progression:” Dust as an All-Inclusive, Multifunctional Metaphor in Philip Pullman's "His Dark Materials", Children's Literature in Education, 32.2 (2001), 111-23.

BIRKIN, ANDREW, J.M. Barrie \& the Lost Boys (London: Constable, 1979).

BIVONA, DANIEL, 'Alice the Child-Imperialist and the Games of Wonderland,' Nineteenth-Century Literature, 41.2 (1986), 143-71.

BLAKE, WILlIAM, Poems and Prophecies, intro. Kathleen Raine (London: Everyman's Library, 1991).

BLOOM, CLIVE, ed., Gothic Horror: A Reader's Guide from Poe to King and Beyond (Basingstoke: Macmillan, 1998).

BLOOM, HAROLD, 'Can 35 Million Book Buyers Be Wrong? Yes,' The Wall Street Journal, July 112000.

BOTTING, FRED, Gothic (London: Routledge, 1996).

BREWER, JOHN, The Pleasures of the Imagination: English Culture in the Eighteenth Century (Chicago: University of Chicago Press, 2000).

BREWSTER, SCOTT, et al., ed., Inhuman Reflections: Thinking the Limits of the Human (Manchester: Manchester University Press, 2000).

BRODRIBB, C.W., 'Mrs Barbauld's School,' Contemporary Review, 148 (Dec. 1935), 731 6.

BRØNDSTED, KATRINE, \& CAY DOLLERUP, 'The Names in Harry Potter,' Perspectives: Studies in Translatology, 12.1 (2004), 56-72.

BYATT, A.S., 'Queen of Hearts and Minds,' The Guardian (14 December 2002), 4-6.

BYRON, GLENNIS, \& DAVID PUNTER, ed., Spectral Readings: Towards a Gothic Geography (London: Macmillan Press, 1999).

CALDECOTT, LEONIE, 'Narnia - a Taste of Paradise,' The Chesterton Review, 17.3-4 (1991), 415-8.

CARPENTER, HUMPHREY, \& MARI PRICHARD, The Oxford Companion to Children's Literature (Oxford: Oxford University Press, 1984). 
CARPENTER, HUMPHREY, Secret Gardens: A Study of the Golden Age of Children's Literature (Boston: Houghton Mifflin Company, 1985).

CASTLE, TERRY, The Female Thermometer: Eighteenth-Century Culture and the Invention of the Uncanny (Oxford: Oxford University Press, 1995).

CHANDLER, ANNE K., 'Pedagogical Fantasies: Rousseau, Maleness, and Domesticity in the Fiction of Thomas Day, Maria Edgeworth, and Mary Wollstonecraft' (unpublished doctoral thesis, Duke University, 1995).

CHANDLER, DAVID, “"Mrs. Barbauld's School” and its Poetic Staff,' Notes and Queries, 44 (June 1997), 225-7.

CHARPENTIER, JOHN, Rousseau: The Child of Nature (London: Methuen \& Co., 1931).

CIXOUS, HELÉNĖ, 'Introduction to Lewis Carroll's Through the Looking-Glass and The Hunting of the Snark,' New Literary History, 13.2 (1982), 231-51.

CLARK, KENNETH, The Gothic Revival: An Essay on the History of Taste, $3^{\text {rd }}$ edn (London: John Murray, 1962).

COHEN, EMILY JANE, 'Museums of the Mind: The Gothic and the Art of Memory,' ELH, 62.4 (1995), 883-905.

COHEN, JEFFREY JEROME, ed., Monster Theory: Reading Culture (Minneapolis: University of Minnesota Press, 1996).

COHEN, MORTON N., \& ANITA GANDALFO, ed., Lewis Carroll and the House of Macmillan (Cambridge: Cambridge University Press, 1987).

COLEMAN, DOROTHY, 'Rabelais \& "The Water-Babies," Modern Language Review, 66 (1971), 511-21.

COLLINGWOOD, STUART DODGSON, The Life and Letters of Lewis Carroll (Rev. C. L. Dodgson) (London: T. Fisher Unwin, 1899).

COREN, MICHAEL, The Man Who Created Narnia (Grand Rapids, Michigan: Williams B. Eerdmans Publishing Company, 1994).

CORNWELL, NEIL, The Literary Fantastic: From Gothic to Postmodernism (Hemel Hempstead: Harvester Wheatsheaf, 1990).

COURTINE, JEAN-FRANÇOIS, et al., Of the Sublime: Presence in Question, trans. by Jeffrey S. Librett, (Albany, N.Y.: State University of New York Press, 1993).

COYLE, WILLIAM, ed., Aspects of Fantasy. Selected Essays from the Second International Conference on the Fantastic in Literature and Film (Westport, Connecticut: Greenwood Press, 1986).

CRIPPS, ELIZABETH A., 'Lewis Carroll, and Charles and Henry Kingsley,' Jabberwocky, 9 (1980), 59-66. 
CUNNINGHAM, VALENTINE, 'Soiled Fairy: The Water-Babies in its Time,' Essays in Criticism, 35 (1985), 121-48.

CUSICK, EDMUND GWILYM, 'George MacDonald and Victorian Fantasy' (unpublished doctoral thesis, University of Oxford, 1988).

CUTT, M. NANCY, Mrs. Sherwood and her Books for Children (London: Oxford University Press, 1974).

DARLING, JOHN, How We See Children: The Legacy of Rousseau's Emile (Aberdeen: Centre for Educational Research, University of Aberdeen, 2000).

DE BOLLA, PETER, The Discourse of the Sublime: Readings in History, Aesthetics and the Subject (Oxford: Basil Blackwell, 1989).

DE LA MARE, WALTER, Lewis Carroll (London: Faber and Faber, 1932).

DEMERS, PATRICIA, Heaven Upon Earth: The Form of Moral and Religious Children's Literature, to 1850 (Knoxville: University of Tennessee Press, 1993).

DERRIDA, JACQUES, Points... Interviews, 1974-1994, ed. Elisabeth Weber, trans. Peggy Kamuf, et al., (Stanford, California: Stanford University Press, 1995).

DOBINSON, C.H., Jean-Jacques Rousseau: His Thought and its Relevance Today (London: Methuen \& Co., 1969).

DRABBLE, MARGARET, ed., The Oxford Companion to English Literature (Oxford: Oxford University Press, 1995).

DUNBAR, JANET, J.M. Barrie: The Man Behind the Image (London: Collins, 1970).

EGAN, MICHAEL, 'The Neverland of Id: Barrie, Peter Pan, and Freud,' Children's Literature, 10 (1982), 37-55.

ELLIS, MARKMAN, The History of Gothic Fiction (Edinburgh: Edinburgh University Press, 2000).

ELLIS, MARKMAN, The Politics of Sensibility: Race, Gender and Commerce in the Sentimental Novel (Cambridge: Cambridge University Press, 1996).

EMPSON, WILLIAM, Some Versions of Pastoral (London: Chatto \& Windus, 1950).

FERGUSON, FRANCES, Solitude and the Sublime: Romanticism and the Aesthetics of Individuation (London: Routledge, 1992).

FERGUSON, MOIRA, 'Sarah Trimmer's Warring Worlds,' Children's Literature Association Quarterly, 21.3 (1996), 105-10.

FISHER, JOHN, ed., The Magic of Lewis Carroll (London: Thomas Nelson and Sons, 1973).

FISHER, LEONA W., 'Mystical Fantasy for Children: Silence and Community,' The Lion and the Unicorn, 14 (1990), 37-57. 
FORD, PAUL D., Companion to Narnia, 4th edn (New York: Harper San Francisco, 1994).

FOUCAULT, MICHEL, Language, Counter-Memory, Practice: Selected Essays and Interviews, ed. Donald F. Bouchard, trans. Donald F. Bouchard \& Sherry Simon (Ithaca, New York: Cornell University Press, 1977).

FOWLER, ALASTAIR, Kinds of Literature: An Introduction to the Theory of Genres and Modes (Oxford: Clarendon Press, 1982).

FREEMAN, BARBARA, 'Frankenstein with Kant: A Theory of Monstrosity, or the Monstrosity of Theory,' Substance, 52 (1987), 21-31.

GATTEGÉGNO, JEAN, Lewis Carroll: Fragments of a Looking-Glass From Alice to Zeno, trans. Rosemary Sheed (London: George Allen \& Unwin, 1977).

GEER, JENNIFER, “"All sorts of pitfalls and surprises:” Competing Views of Idealized Girlhood in Lewis Carroll's Alice Books,' Children's Literature, 31 (2003), 1-24.

GIGNILLIAT, GEORGE WARREN, The Author of Sandford and Merton: A Life of Mr. Thomas Day, Esq. (New York: Columbia University Press, 1932).

GOETSCH, PAUL, Monsters in English Literature: From the Romantic Age to the First World War (Frankfurt am Main: Peter Lang, 2002).

GOODERHAM, DAVID, 'Fantasizing it as it is: Religious Language in Philip Pullman's Trilogy, His Dark Materials,' Children 's Literature, 31 (2003), 155-75.

GRAHAM, ELAINE L., Representations of the Post/Human: Monsters, Aliens and Others in Popular Culture (Manchester: Manchester University Press, 2002).

GRANGER, JOHN, The Hidden Key to Harry Potter: Understanding the Meaning, Genius, and Popularity of Joanne Rowling's Harry Potter Novels (Port Hadlock, WA: Zossima Press, 2002).

GREEN, ROGER LANCELYN, \& WALTER HOOPER, C.S. Lewis: A Biography (London: Collins, 1974).

GREEN, ROGER LANCELYN, Fifty Years of Peter Pan (London: Peter Davies, 1954).

GRIESINGER, EMILY, 'Harry Potter and the "Deeper Magic": Narrating Hope in Children's Literature,' Christianity and Literature, 51.3 (2002), 455-480.

GRIXTI, JOHN, Terrors of Uncertainty: The Cultural Contexts of Horror Fiction (London: Routledge, 1989).

GRYNBAUM, GAIL A., 'The Secrets of Harry Potter,' The San Francisco Jung Institute Library Journal, 19.4 (2001), 17-48.

GUEST, HARRIET, Small Change: Women, Learning, Patriotism, 1750-1810 (Chicago: University of Chicago Press, 2000). 
GUNTER, BARRIE, Jill L. McAleer, Children and Television: The One Eyed Monster? (London: Routledge, 1990).

GUPTA, SUMAN, Re-Reading Harry Potter (Basingstoke, Hampshire: Palgrave Macmillan, 2003).

HAMMERTON, J.A., Barrie: The Story of a Genius (London: Sampson Low, Marston \& co., 1929).

HARVEY DARTON, F.J., J.M. Barrie (London: Nisbet \& Co., n.d.).

HAWLEY, JOHN C., 'The Water-Babies as Catechetical Paradigm,' The Children's Literature Association Quarterly, 14.1 (1989), 19-21.

HEIN, ROLLAND, The Harmony Within: The Spiritual Vision of George MacDonald (Washington, D.C.: Christian College Consortium, 1982).

HERTZ, NEIL, The End of the Line: Essays on Psychoanalysis and the Sublime (New York: Columbia University Press, 1985).

HOLBROOK, DAVID, The Skeleton in the Wardrobe: C.S. Lewis's Fantasies: A Phenomenological Study (London: Associated University Presses, 1991).

HOLTE, JAMES CRAIG, ed., The Fantastic Vampire: Studies in the Children of the Night. Selected Essays from the Eighteenth International Conference on the Fantastic in the Arts (Westport, Connecticut: Greenwood Press, 2002).

HOOPER, WALTER, C.S. Lewis: A Companion and Guide (London: HarperCollinsPublishers, 1996).

HOOPER, WALTER, Past Watchful Dragons (London: Fount Paperbacks, 1980).

HOPKINS, MARY ALDEN, Hannah More and Her Circle (New York: Longmans, Green \& Co., 1947).

HUET, MARIE-HÉLÈNE, Monstrous Imagination (Cambridge, Massachesetts: Harvard University Press, 1993).

HUNT, PETER, ed., Children's Literature: An Anthology 1801-1902 (Oxford: Blackwell Publishers, 2001).

HUNT, PETER, ed., Children's Literature: An Illustrated History (Oxford: Oxford University Press, 1995).

HUNT, PETER, ed., Understanding Children's Literature, $2^{\text {nd }}$ edn (London: Routledge, 2005).

JACK, R.D.S., The Road to the Never Land: A Reassessment of $J M$ Barrie's Dramatic Art (Aberdeen: Aberdeen University Press, 1991).

JAEGER, MURIEL, Experimental Lives: From Cato to George Sand (London: G. Bell \& Sons, 1932. 
JOHNSON, ARTHUR, 'The Water-Babies: Kingsley's Debt to Darwin,' English, 12 (195859), 215-9.

JOHNSON, BARBARA, 'My Monster / My Self,' Diacritics, 12 (1982), 2-10.

JONES, DUDLEY, \& TONY WATKINS, ed., A Necessary Fantasy? The Heroic Figure in Children's Popular Culture (New York: Garland Publishing, 2000).

JONES, JO ELWYN, \& J. FRANCIS GLADSTONE, The "Alice" Companion: A Guide to Lewis Carroll's "Alice" Books (London: Macmillan Press Ltd, 1998).

JONES, STEVE, In the Blood: God, Genes and Destiny (London: Flamingo, 1997).

JOSEPH, GERHARD, 'Frankenstein's Dream: The Child as Father of the Monster,' Hartford Studies in Literature, 7 (1975), 97-115.

KARKAINEN, PAUL A., Narnia Explored (Old Tappan, New Jersey: Fleming H. Revell Company, 1979).

KELLEY-LAINÉ, KATHLEEN, Peter Pan: The Story of a Lost Childhood (Shaftesbury, Dorset: Element, 1997).

KENNEDY, THOMAS C., 'From Anna Barbauld's Hymns in Prose to William Blake's Songs of Innocence and of Experience,' Philological Quarterly, 77.4 (Fall 1998), 359-76.

KERN, EDMUND M., The Wisdom of Harry Potter: What Our Favorite Hero Teaches Us About Moral Choices (New York: Prometheus Books, 2003).

KETTERER, DAVID, Frankenstein's Dream: The Book, the Monster, and Human Reality (B.C., Canada: English Literary Studies, University of Victoria, 1979).

KEUTSCH, WILFRIED, 'Touching the Poor: Sarah Trimmer, God's Own Handmaid,' Bulletin of the John Rylands University Library of Manchester, 76.3 (Autumn 1994), 4357.

KHODDAM, SALWA, 'The Significance of the East in C.S. Lewis' The Voyage of the Dawn Treader and Other Narnia Stories: Topos or Cosmos?' The Bulletin of the New York C.S. Lewis Society, 29 (1998), 1-10.

KILGOUR, MAGGIE, The Rise of the Gothic Novel (London: Routledge, 1995).

KING, DON, 'Narnia and the Seven Deadly Sins,' Mythlore, 38 (1984), 14-9.

KING, DON. W., 'The Childlike in George MacDonald and C.S. Lewis,' Mythlore, 12 (1986), 17-22, 26, http://cslewis.drzeus.net/papers/childlike.html

KISSEL, SUSAN S., "'But When at Last She Really Came, I Shot Her:" Peter Pan and the Drama of Gender,' Children's Literature in Education, 19.1 (1988), 32-41.

KNOEPFLMACHER, U.C., 'Avenging Alice: Christina Rossetti and Lewis Carroll,' Nineteenth-Century Literature, 41.3 (1986), 299-328. 
KNOEPFLMACHER, U.C., 'The Balancing of Child and Adult: An Approach to Victorian Fantasies for Children,' Nineteenth-Century Fiction, 37.4 (1983), 497-530.

KNOEPFLMACHER, U.C., Ventures into Childland: Victorians, Fairy Tales, and Femininity (Chicago: University of Chicago Press, 1998).

KOFMAN, SARAH, Freud and Fiction, trans. Sarah Wykes (Cambridge: Polity Press, 1991).

KRISTEVA, JULIA, Powers of Horror: An Essay on Abjection, trans. Leon S. Roudiez (New York: Columbia University Press, 1982).

LAPLANCHE, J., \& J.-B. PONTALIS, The Language of Psycho-Analysis, trans. Donald Nicholson-Smith (London: The Hogarth Press, 1973).

LEAVIS, Q.D., 'The Water-Babies,' Children's Literature in Education, 23 (1976), 155-63.

LENNON, FLORENCE BECKER, Victoria Through the Looking-Glass: The Life of Lewis Carroll (New York: Simon and Schuster, 1945).

LINDSKOOG, KATHRYN ANN, The Lion of Judah in Never-Never Land: The Theology of C.S. Lewis Expressed in His Fantasies for Children (Grand Rapids, Michigan: William B. Eerdmans Publishing Company, 1973).

LONGUEIL, ALFRED E., 'The Word "Gothic" in Eighteenth Century Criticism,' MLN, 38.8 (1923), 453-60.

LOVERIDGE, MARK, 'The Water-Babies' (unpublished lecture notes, University of Wales Swansea, n.d.).

LURIE, ALISON: Boys and Girls Forever: Reflections on Children's Classics (London: Chatto \& Windus, 2003).

LYDENBERG, ROBIN, ‘Freud's Uncanny Narratives,' PMLA, 112 (1997), 1072-86.

LYOTARD, JEAN-FRANÇOISE, The Postmodern Condition: A Report on Knowledge, trans. Geoff Bennington \& Brain Massumi (Manchester: Manchester University Press, 1984).

MACNEICE, LOUIS, Varieties of Parable (Cambridge: Cambridge University Press, 1965).

MADDEN, WILLIAM A., 'Framing the Alices,' PMLA, 101.3 (1986), 362-73.

MAHON, PENNY, “'Things by Their Right Name:” Peace Education in Evenings At Home,' Children's Literature, 28 (2000), 164-74.

MAKMAN, LISA HERMINE, 'Child's Work is Child Play: The Value of George MacDonald's Diamond,' Children's Literature Association Quarterly, 24.3 (1999), 11929.

MANLOVE, C.N., Modern Fantasy: Five Studies (Cambridge: Cambridge University Press, 1975). 
MANLOVE, COLIN, From Alice to Harry Potter: Children's Fantasy in England (Christchurch, New Zealand: Cybereditions, 2003).

MCCARTHY, WILLIAM, 'Mother of All Discourses: Anna Barbauld's Lessons for Children,' Princeton University Library Chronicle, 60.2 (Winter 1999), 196-219, http://ccl.princeton.edu/index.php?app $=$ download\&id $=100$

MCCARTHY, WILLIAM, 'The Celebrated Academy at Palgrave: A Documentary History of Anna Letitia Barbauld's School,' Age of Johnson, 8 (1997), 279-392.

MCGANN, JEROME, The Poetics of Sensibility: A Revolution in Literary Style (Oxford: Clarendon Press, 1996).

MCGAVRAN, JAMES HOLT, ed., Romanticism and Children's Literature in NineteenthCentury England (Athens, Georgia: University of Georgia Press, 1991).

MCGILLIS, RODERICK, ed., For the Childlike: George MacDonald's Fantasies for Children (Metuchen, N.J. \& London: The Children's Literature Association \& The Scarecrow Press, Inc., 1992).

MILES, ROBERT, Gothic Writing 1750-1820: A Genealogy (London: Routledge, 1993).

MONK, SAMUEL H., The Sublime: A Study of Critical Theories in XVIII-Century England (Ann Arbor: University of Michigan Press, 1960).

MORHAN, CLOTILDE, 'Sacramentalism or the Profane World Revisited: A Study of Lewis's Chronicles of Narnia' (unpublished thesis, Université de Lille III, 1999-2000).

MORRIS, DAVID B., 'Gothic Sublimity,' NLH, 16 (1984-85), 299-319.

MORTON, LIONEL, 'Memory in the Alice Books,' Nineteenth-Century Fiction, 33.3 (1978), 285-308.

MORUZI, KRISTINE, 'Missed Opportunities: The Subordination of Children in Philip Pullman's His Dark Materials,' Children's Literature in Education, 36.1 (2005), 55-68.

MURCH, JEROM, Mrs Barbauld and her Contemporaries; Sketches of Some Eminent Literary and Scientific Englishwomen (London: Longman, Green and Co., 1877).

NEAL, CONNIE: The Gospel According to Harry Potter: Spirituality in the Stories of the World's Most Famous Seeker (London: Westminster John Knox Press, 2002).

NEWMAN, GERALD, The Rise of English Nationalism: A Cultural History, 1740-1830 (London: Weidenfeld \& Nicolson, 1987).

O'BRIEN, MICHAEL D., 'Harry Potter and the Paganization of Children's Culture,' Catholic World Report, April 2001.

OPIE, PETER \& IONA, The Oxford Nursery Rhyme Book (Oxford: Oxford University Press, 1977).

ORME, NICHOLAS, Medieval Children (New Haven: Yale University Press, 2001). 
OUSBY, IAN, The Cambridge Guide to Literature in English (Cambridge: Cambridge University Press, 1993).

Oxford English Dictionary, http://www.oed.com

PADLEY, JONATHAN, 'Frankenstein and (Sublime) Creation,' Romanticism, 9.2 (2003), 196-212.

PADLEY, KENNETH, 'The Theology of Robert South, 1634-1716' (unpublished thesis, University of Oxford, 2004).

PARSONS, WENDY, \& CATRIONA NICHOLSON, 'Talking to Philip Pullman: An Interview,' The Lion and the Unicorn, 23 (1999), 116-34.

PATTERSON, NANCY-LOU, 'Always Winter and Never Christmas: Symbols of Time in Lewis' Chronicles of Narnia,' Mythlore, 67 (1991), 10-4.

PENNINGTON, JOHN, 'Alice at the Back of the North Wind, or the Metafictions of Lewis Carroll and George MacDonald,' Extrapolation, 33.1 (1992), 59-72.

PENNINGTON, JOHN, 'From Elfland to Hogwarts, or the Aesthetic Trouble with Harry Potter,' The Lion and the Unicorn, 26 (2002), 78-97.

PETZOLD, DIETER, 'Maturation and Education in George MacDonald's Fairy Tales,' North Wind, 12 (1993), 10-24.

PHILIPS, ROBERT, ed., Aspects of Alice (Harmondsworth: Penguin, 1971).

PICKERING, SAM, 'The Cheap Repository Tracts and the Short Story,' Studies in Short Fiction, 12 (1975), 15-21.

PIETRUSZ, JIM, 'Rites of Passage: The Chronicles of Narnia \& the Seven Sacraments,' Mythlore, 54 (1988), 61-3.

PLOTZ, JUDITH, Romanticism and the Vocation of Childhood (New York: Palgrave, 2001).

PORTER, ROY, Enlightenment: Britain and the Creation of the Modern World (London: Penguin Books, 2000).

PRIDMORE, JOHN, 'Modern Myths of Good \& Evil,' St Martin in the Fields - Church, http://www2.stmartin-in-the-fields.org/page/church/sermons/Oct\%2030\%2005\%20JP.pdf

PUDNEY, JOHN, Lewis Carroll and His World (London: Thames \& Hudson, 1976).

PULLMAN, PHILIP, 'Let's Write it in Red: The Patrick Hardy Lecture,' Signal: Approaches to Children's Books, 85 (1998), 44-62.

PUNTER, DAVID, A History of Gothic Fiction from 1765 to the Present Day, 2 vols (London: Longman, 1996).

PUNTER, DAVID, ed., A Companion to the Gothic (Oxford: Blackwell Publishers, 2000). 
QUINN, DENNIS B., 'The Narnia Books of C.S. Lewis: Fantastic or Wonderful?' Children's Literature, 12 (1984), 105-21.

RACKIN, DONALD, 'Alice's Journey to the End of the Night,'PMLA, 81 (1966), 313-26.

RAEPER, WILLIAM, ed., The Gold Thread: Essays on George MacDonald (Edinburgh: Edinburgh University Press, 1990).

RAEPER, WILIAM, George MacDonald (Herts: Lion Publishing, 1987).

RAHN, SUZANNE, Rediscoveries in Children's Literature (London: Garland Publishing, 1995).

RANDALL, JESSY, 'Wizard Words: The Literary, Latin, and Lexical Origins of Harry Potter's Vocabulary,' Verbatim, 26.2 (2001), 1-7.

REGAIGNON, DARA ROSSMAN, 'Intimacy's Empire: Children, Servants, and Missionaries in Mary Martha Sherwood's "Little Henry and his Bearer," Children's Literature Association Quarterly, 26.2 (2001), 84-95.

RIBEIRO, ALVARO, \& JAMES G. BASKER, Tradition in Transition: Women Writers, Marginal Texts, and the Eighteenth-Century Canon (Oxford: Clarendon Press, 1996).

RICOEUR, PAUL, Hermeneutics and the Human Sciences: Essays on Language, Action and Interpretation, ed. John B. Thompson, trans. John B. Thompson (Cambridge: Cambridge University Press, 1981).

RIGGIO, THOMAS P., 'American Gothic: Poe and an American Tragedy,' American Literature, 49.4 (1978), 515-32.

RIGSBEE, SALLY, 'Fantasy Places and Imaginative Belief: The Lion, the Witch, and the Wardrobe and The Princess and the Goblin,' Children's Literature Association Quarterly, 8 (1983), 10-1.

RILEY, PATRICK, ed., The Cambridge Companion to Rousseau (Cambridge: Cambridge University Press, 2001).

ROBBINS, SARAH, 'Lessons for Children and Teaching Mothers: Mrs. Barbauld's Primer for the Textual Construction of Middle-Class Domestic Pedagogy,' The Lion and the Unicorn, 17.2 (1993), 135-51.

ROBINSON, HENRY CRABB, On Books and Their Writers, ed. Edith J. Morley, 3 vols (London: J.M. Dent \& Sons, 1938).

ROSE, JACQUELINE, The Case of Peter Pan, or the Impossibility of Children's Fiction (Philadelphia: University of Pennsylvania Press, 1993).

ROUTH, CHRIS, "'Man for the Sword and for the Needle She:" Illustrations of Wendy's Role in J.M. Barrie's Peter and Wendy,' Children's Literature in Education, 32.1 (2001), 57-75. 
ROWE, DONELLE, 'Guarding the British Bible from Rousseau: Sarah Trimmer, William Godwin, and the Pedagogical Periodical,' Children's Literature, 29 (2001), 1-17.

ROWLAND, PETER, The Life and Times of Thomas Day, 1748-1789: Virtue Almost Personified (Lewiston / Queenston / Lampeter: The Edwin Mellers Press, 1996).

ROWLING, J.K., 'Larry King Live: J.K. Rowling Discusses the Surprising Success of Harry Potter,' CNN Transcript, http://transcripts.cnn.com/transcripts/0010/20/lkl.00.html

SADLER, MICHAEL, Thomas Day: An English Disciple of Rousseau (Cambridge: Cambridge University Press, 1928).

SAGE, VICTOR, ed., The Gothick Novel: A Casebook (Basingstoke: Macmillan, 1990).

SAUNDERS, BETTY, 'The Harsh Morality of the Narnia Stories,' The Chesterton Review, 17.3-4 (1991), 413-5.

SAYERS, WILLIAM, 'C.S. Lewis and the Toponym Narnia,' Mythlore, 84 (1998), 54-5, 58.

SCHAKEL, PETER J., Imagination and the Arts in C.S. Lewis: Journeying to Narnia and Other Worlds (Columbia: University of Missouri Press, 2002).

SCHAKEL, PETER J., Reading with the Heart: The Way into Narnia (Grand Rapids, Michigan: William B. Eerdmans Publishing Company, 1979).

SCHAKEL, PETER J., 'The "Correct" Order for Reading the Chronicles of Narnia?,' Mythlore, 88 (2001), 4-14.

SCHEUERMANN, MONA, 'More than "A Few Passages:" Henry Brook's The Fool of Quality as the Source of Thomas Day's The History of Sandford and Merton,' Durham University Journal, 75.2 (1983), 55-9.

SCOTT, S.H., The Exemplary Mr Day, 1748-1789, Author of Sandford and Merton (London: Faber and Faber, 1935).

SEDGWICK, EVE KOSOFSKY, ed., Novel Gazing: Queer Readings in Fiction (Durham: Duke University Press, 1997).

SHABERMAN, R.B., 'Lewis Carroll and George MacDonald,' Jabberwocky, 5 (1976), 6787.

SHAVIT, ZOHAR, 'The Ambivalent Status of Texts: The Case of Children's Literature, Poetics Today, 1.3 (1980), 75-86.

SILVERSTONE, BEN, 'Children, Monsters and Words in Alice's Adventures in Wonderland and Through the Looking-Glass,' Cambridge Quarterly, 30.4 (2001), 319-36.

SMITH, ANDREW, Gothic Radicalism: Literature, Philosophy and Psychoanalysis in the Nineteenth Century (London: Macmillan Press, 2000).

SOTO, FERNANDO, "Some Linguistic Moves in the Carroll-MacDonald "Literary Game,"' North Wind, 18 (1999), 45-53. 
SQUIRES, CLAIRE, Philip Pullman's His Dark Materials Trilogy: A Reader's Guide (New York: Continuum, 2003).

STANLEY, LAWRENCE KENT, 'Metaphoricity and the Sublime Moment: Studies in Some Contemporary Theories of the Sublime' (unpublished doctoral thesis, University of Oxford, 1991).

STEVENSON, DEBORAH, 'Sentiment and Significance: The Impossibility of Recovery in the Children's Literature Canon or, the Drowning of The Water-Babies,' The Lion and the Unicorn, 21 (1997), 112-30.

STONE, LAWRENCE, The Family, Sex and Marriage in England 1500-1800, abr. edn (London: Penguin, 1990).

STRIMEL, COURTNEY B., 'The Politics of Terror: Rereading Harry Potter,' Children's Literature in Education, 35.1 (2004), 35-52.

SUMMERFIELD, GEOFFREY, Fantasy and Reason: Children's Literature in the Eighteenth Century (Athens: The University of Georgia Press, 1984).

SUMMERS, MONTAGUE, $A$ Gothic Bibliography (London: The Fortune Press, n.d.).

SUMMERS, MONTAGUE, The Gothic Quest: A History of the Gothic Novel (London: The Fortune Press, 1938).

TAYLOR, ALEXANDER L., The White Knight: A Study of C.L. Dodgson (Lewis Carroll) (Edinburgh: Oliver \& Boyd, 1952).

THACKER, DEBORAH CORGAN, \& JEAN WEBB, Introducing Children's Literature: From Romanticism to Postmodernism (London: Routledge, 2002).

TIFFIN, CHRIS, \& ALAN LAWSON, ed., De-scribing Empire: Post-colonialism and Textuality (London: Routledge, 1994).

TODD, JANET, Sensibility: An Introduction (London: Methuen \& Co., 1986).

TODOROV, TZVETAN, The Fantastic: A Structural Approach to a Literary Genre, trans. Richard Howard (Ithaca, New York: Cornell University Press, 1975).

TOWNSEND, JOHN ROWE, Written for Children: An Outline of English-Language Children's Literature (Harmondsworth: Penguin, 1974).

TUCKER, NICHOLAS, Darkness Visible: Inside the World of Philip Pullman (Cambridge: Wizard Books, 2003).

UGLOW, JENNY, The Lunar Men: The Friends Who Made the Future 1730-1810 (London: Faber \& Faber, 2002).

VALLONE, LYNNE, “A Humble Spirit Under Correction": Tracts, Hymns, and the Ideology of Evangelical Fiction for Children, 1780-1820,' The Lion and the Unicorn, 15 (1991), 72-95. 
WALBROOK, H.M., J.M. Barrie and the Theatre (London: F.V. White \& Co., 1922).

WARD, MICHAEL, 'The Son and the Other Stars: Christology and Cosmology in the Imagination of C.S. Lewis,' (unpublished doctoral thesis, University of St Andrews, 2005).

WARNER, MARINA, Managing Monsters: Six Myths of Our Time (London: Vintage, 1994).

WEISKEL, THOMAS, The Romantic Sublime: Studies in the Structure and Psychology of Transcendence (Baltimore: Johns Hopkins University Press, 1976).

WELSH, CHARLES, A Bookseller of the Last Century: Being Some Account of the Life of John Newbery, and of the Books he Published, with a Notice of the later Newberys (London: [printed for] Griffith, et al., 1885).

WHITED, LANA A., ed., The Ivory Tower and Harry Potter: Perspectives on a Literary Phenomenon (Missouri: University of Missouri Press, 2002).

WILLIAMS, DAVID, Deformed Discourse: The Function of the Monster in Mediaeval Thought and Language (Exeter: Exeter University Press, 1996).

WILlIAMS, LINDA RUTH, Critical Desire: Psychoanalysis and the Literary Subject (London: Edward Arnold, 1995).

WILLIAMS, ROWAN, On Christian Theology (Oxford: Blackwell Publishers, 2000).

WILLIAMS, SIDNEY HERBERT, FALCONER MADAN, \& ROGER LANCELYN GREEN, The Lewis Carroll Handbook: Being a New Version of 'A Handbook of the Literature of the Rev. C.L. Dodgson' (London: Dawsons of Pall Mall, 1970).

WILSON, ADRIAN, 'The Infancy of the History of Childhood: An Appraisal of Philippe Ariès,' History and Theory, 19 (1980), 132-53.

WINTER, DOUGLAS E., Clive Barker: The Dark Fantastic (London: HarperCollinsPublishers, 2002).

WOLFE, GREGORY, 'C.S. Lewis's Debt to George MacDonald,' The Bulletin of the New York C.S. Lewis Society, 15.2 (1983), 1-7.

WOLFF, ROBERT LEE, The Golden Key: A Study of the Fictions of George MacDonald (New Haven: Yale University Press, 1961).

WOLFREYS, JULIAN, Spectrality, Gothic, the Uncanny and Literature (New York: Palgrave, 2002).

WOOD, NAOMI, 'Paradise Lost and Found: Obedience, Disobedience, and Storytelling in C.S. Lewis and Philip Pullman,' Children's Literature in Education, 32.4 (2001), 237-59.

WORSLEY, HOWARD, 'Popularized Atonement Theory Reflected in Children's Literature,' The Expository Times, 115.5 (2004), 149-56. 
WULLSCHLÄGER, JACKIE, Inventing Wonderland (London: Methuen, 1995).

YEOMAN, ANN, Now or Neverland: Peter Pan and the Myth of Eternal Youth (Toronto: Inner City Books, 1998).

ZALL, PAUL M., 'Wordsworth's “Ode” \& Mrs. Barbauld's Hymns,' The Wordsworth Circle, I.4, (Autumn 1970), 177-9.

ZIPES, JACK, Sticks and Stones: The Troublesome Success of Children's Literature from Slovenly Peter to Harry Potter (London: Routledge, 2002).

ZORNADO, JOSEPH L., Inventing the Child: Culture, Ideology, and the Story of Childhood (New York: Garland Publishing, 2001).

ZUNSHINE, LISA, 'Rhetoric, Cognition, and Ideology in A.L. Barbauld's Hymns in Prose for Children (1781),' Poetics Today, 23.1 (2002), 123-39. 